JOAQUIN IGNACIO BONNECARRERE GARCIA

\title{
SISTEMA DE SUPORTE A DECISÃO PARA O LANÇAMENTO DE
}

\section{EFLUENTES}

Tese apresentada à Escola Politécnica da Universidade de São Paulo para obtenção do título de Doutor em Engenharia 
JOAQUIN IGNACIO BONNECARRERE GARCIA

\section{SISTEMA DE SUPORTE A DECISÃO PARA O LANÇAMENTO DE}

\section{EFLUENTES}

Tese apresentada à Escola Politécnica da Universidade de São Paulo para obtenção do título de Doutor em Engenharia

Área de Concentração: Engenharia Hidráulica

Orientador: Prof. Dr. Rubem La Laina Porto 
Este exemplar foi revisado e alterado em relação à versão original, sob responsabilidade única do autor e com a anuência de seu orientador.

São Paulo, 23 de maio de 2011.

Assinatura do autor

Assinatura do orientador

FICHA CATALOGRÁFICA

Garcia, Joaquin Ignacio Bonnecarrere

Sistema de suporte a decisão para o lançamento de

efluentes / J.I.B. Garcia. -- ed.rev. -- São Paulo, 2011.

$162 \mathrm{p}$.

Tese (Doutorado) - Escola Politécnica da Universidade de São Paulo. Departamento de Engenharia Hidráulica e Sanitária.

1. Recursos hídricos (Gerenciamento) 2. Qualidade da água 3. Modelos matemáticos 4 Otimização Não Linear I. Universidade de São Paulo. Escola Politécnica. Departamento de Engenharia Hidráulica e Sanitária II. t. 
À Ana Paula 


\section{AGRADECIMENTOS}

Agradeço ao meu orientador, Prof. Dr. Rubem La Laina Porto, com o qual tive a oportunidade de aprender e compartilhar de sua brilhante visão sobre o processo de gestão de Recursos Hídricos. Os ensinamentos transmitidos contribuíram para o meu enriquecimento profissional e pessoal.

A Prof ${ }^{a}$. Dra . Monica Porto por ter me aberto as portas da Escola Politécnica e pela atenção e disponibilidade em discutir tópicos importantes para o desenvolvimento desta Tese.

Ao Prof. Dr. Darrell G. Fontane pela boa recepção e orientação no período que estive na Colorado State University e por ter me incentivado no desenvolvimento deste tema tão desafiador.

Aos Professores e funcionários do Departamento de Engenharia Hidráulica e Sanitária, com os quais tive a oportunidade de conviver e trabalhar durantes a minha estadia na Escola Politécnica da USP.

À Fundação de Amparo à Pesquisa do Estado de São Paulo - FAPESP, pela concessão de bolsa de estudo e outros auxílios financeiros concedidos.

Aos amigos e colegas do LabSid: Cristiano P. M. Oliveira, Honório Lisboa, Alexandre Roberto, Satie Ishikawa, Silvana Marcellini, Arisvaldo Mello, João Tercini, Carla Voltareli, Cristiane Amaro, André Sosnoski e Roberto Oliveira pela oportunidade de trabalhar junto e dividir experiências.

Ao amigo e colega André Schardong, com o qual tive a oportunidade de discutir os mais diversos aspectos técnicos, acadêmicos e pessoais.

Ao amigo Sidnei Ono o qual tem estado presente seja para trabalho ou descontração deste minha chegada à São Paulo.

Aos amigos Alan e Ana Carolina Maran, Yuri e Fernanda Dalcanale pela amizade e boa receptividade em Fort Collins.

À minha Família, que sempre me incentivou e apoiou nos meus estudos, e que agora mesmo a distância estão sempre presentes.

A minha esposa Ana Paula, com a qual tenho o prazer de ser colega de profissão, minha companheira de todas as horas, e tem sido sempre um exemplo de determinação o que me da força para enfrentar os desafios no mundo dos recursos hídricos e da vida. 


\section{RESUMO}

Esta tese desenvolveu um Sistema de Suporte a Decisão para auxiliar na concessão de outorga de lançamento de efluentes, através do qual é possível avaliar estratégias de outorga visando facilitar o processo de análise e a efetivação do instrumento. O SSD utiliza em seu processo de análise algoritmos evolucionários para a otimização do processo de alocação de demanda e de carga efluente, visando a maximização dos usos e a minimização dos custos das medidas de tratamento de efluentes, respeitando os limites estabelecidos pela classe de enquadramento dos corpos d'água. Os algoritmos evolutivos analisados foram os Algoritmos Genéticos, Particle Swarm Optimization e o Differential Evolution. Entre as estratégias de outorga consideradas estão o atendimento da legislação ambiental para o lançamento de efluentes, a isonomia entre os usuários, o atendimento aos padrões de qualidade estabelecidos pelo enquadramento dos corpos hídricos e as restrições impostas pelo órgão gestor aos usuários ou as finalidades de uso. Para avaliar o desempenho do SSD foi realizado um estudo de caso na Bacia Hidrográfica do Rio Atibaia, no Estado de São Paulo. O Rio Atibaia foi escolhido por apresentar problemas de disponibilidade hídrica e conflitos pelo uso da água, o que permite avaliar os resultados do SSD para as diferentes estratégias em um caso real. Os resultados obtidos pelos três algoritmos para as estratégias analisadas foram satisfatórios atendendo as restrições e penalidades impostas à função objetivo. Observou-se que a estratégia de outorga que não considerou a Legislação Ambiental para lançamento de efluentes e a questão da isonomia entre os usuários apresentou o menor custo global das medidas de tratamento de efluentes. Este resultado se deve ao fato desta estratégia ser menos restritiva que as demais analisadas, e pelo melhor aproveitamento da vazão disponível no trecho para diluir os efluentes. As estratégias propostas neste estudo tiveram como principal objetivo avaliar o comportamento do SSD na obtenção das análises, assim como analisar a flexibilidade dos algoritmos na introdução de restrições e penalidades. Para a escolha das estratégias de outorga, destaca-se o importante papel do Comitê de Bacia e do órgão gestor para definir as prioridades, tendo em vista que os critérios de outorga, a legislação ambiental e a isonomia, podem acarretar em investimentos mais elevados para a implementação das medidas de tratamento. O Sistema de Suporte a Decisão proposto nesta tese representa um avanço no processo de gestão de recursos hídricos, uma vez que envolve importantes critérios e estratégias na análise da outorga de direito de uso da água, sem dissociar os aspectos de quantidade e qualidade da água e aspectos econômicos para sua efetivação. 


\section{ABSTRACT}

This study presents a Decision Support System (DSS) to assist in the issuing of wastewater discharge and water abstraction rights, including the evaluation of alternative pollution control strategies used to facilitate the analysis and implementation of the instrument. The DSS substantiates its analysis with the use of evolutionary algorithms for the optimization of water demand and wastewater discharge allocation. It intends to maximize the uses and minimize the costs of wastewater treatment measures, according to the limits imposed by the water quality standards. The evolutionary algorithms investigated in this study include Genetic Algorithms, Particle Swarm Optimization and Differential Evolution. Among the strategies considered for the issuing of water rights were the compliance with environmental legislation for wastewater discharge, the equality between water users, the water quality standards set by the water bodies' classification, and the restrictions imposed by the responsible controlling agency. The SSD was evaluated on a case study area, at Atibaia River, located in the State of Sao Paulo. The Atibaia River was chosen because of the existence of innumerous conflicts of over water use and availability. It allows the assessment of the SSD performance, to different strategies, in a real case scenario. The SSD's results, using all three introduced algorithms, were satisfactory to the strategies analyzed, as they complied with the restrictions and penalties imposed to the objective function. Strategy one, with no restrictions or penalties, had the lowest overall cost of wastewater treatment measures, in comparison to strategy two, equity between water users, and three, compliance with Environmental Laws. This result is due to the fact that strategy one is less restrictive than the two others, and because of the best use of the available flow, in each respective reach, to dilute the wastewater discharge. The main objective of the proposed strategies is to evaluate the performance of the SSD in getting the results, as well as to analyze the flexibility of the algorithms when new restrictions and penalties are introduced in the decision making process. Water users, other stakeholders and the responsible controlling agency have an important role in the selection of suitable strategies and priorities of uses. Higher investments to implement water treatment measures may become necessary according to the strategy chosen. In addition, when a strategy is not well defined, it may cause unnecessary investments. The DSS proposed in this study represents an advance in water resources management. It involves important criteria and strategies used in the analysis of wastewater discharge and water abstraction rights, without disassociating water quality and quantity aspects as well as economic factors for its implementation. 


\section{SUMARIO}

1. INTRODUÇAO

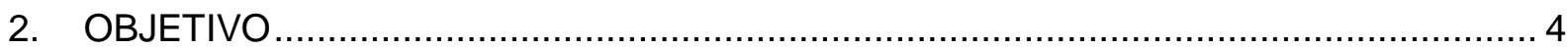

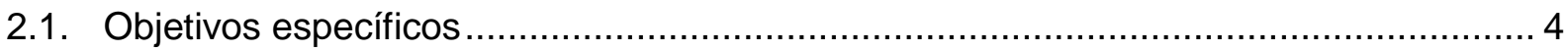

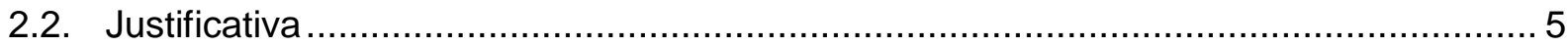

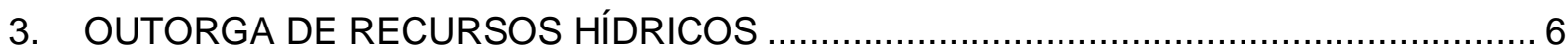

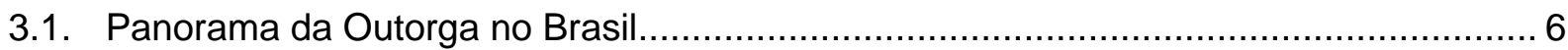

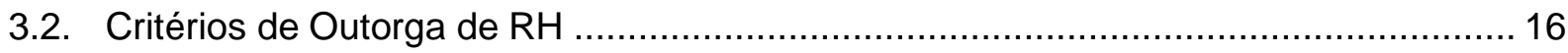

4. OUTORGA DE LANÇAMENTO DE EFLUENTES ……….......................................

4.1. Análise dos problemas e variáveis envolvidas no processo de outorga de efluentes.. 34

4.2. Estudos desenvolvidos para a gestão da outorga de efluentes................................... 41

5. ALGORÍTMOS EVOLUCIONÁRIOS PARA SUPORTE A DECISÃO ………………..... 49

5.1. Algoritmos Genéticos AGs ................................................................................. 53

5.2. Particle Swarm Optimization (PSO) ou "Otimização por Nuvem de Partículas" .......... 58

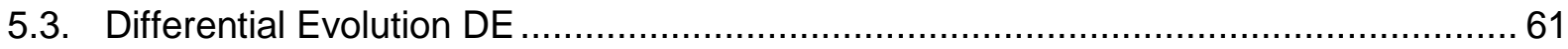

6. SSD PARA OUTORGA DE LANÇAMENTO DE EFLUENTES....................................65

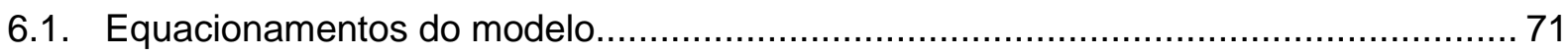

6.2. Algoritmos de otimização aplicados ao processo de outorga de $\mathrm{RH}$............................76

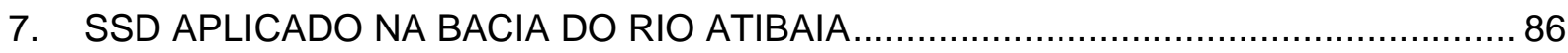

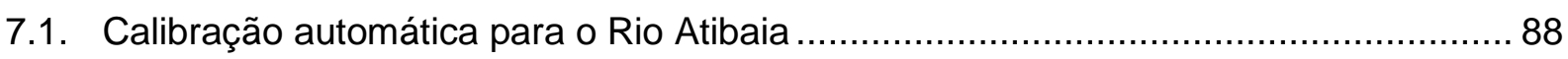

7.2. Análise da outorga de efluentes na Bacia do Rio Atibaia ...........................................98

7.3. Considerações do sobre o SSD proposto para Outorga de Efluentes ........................ 129

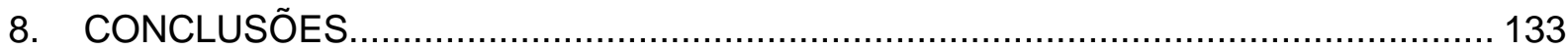

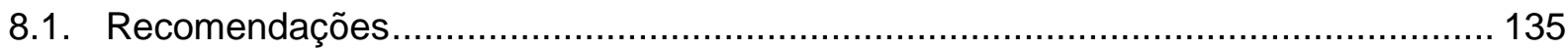

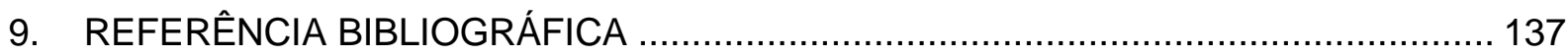

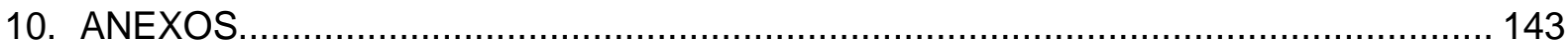

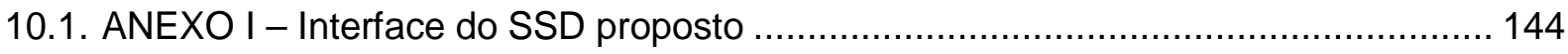

10.2. ANEXO II -Dados das Estação de Monitoramento Quantitaivo e Qualitativo na Bacia do Atibaia. 
10.3. ANEXO III - Dados de Entrada do modelo 


\section{LISTA DE FIGURAS}

Figura 3.1 - Evolução do quadro geral de outorgas emitidas no país (Fonte: ANA, 2010) ..... 7

Figura 3.2 - Funções de custo para tratamento primário avançado e lagoas 28

Figura 3.3 - Funções de custo para o sistema de reator UASB e para o sistema de UASB seguido de lodo ativado

Figura 3.4 - Funções de custo para o sistema de lodo ativado seguido de pós-tratamento . 29 Figura 4.1 - Distribuição das vazões outorgadas no Brasil quanto aos usos (ANA, 2009)... 33

Figura 4.2 - Lançamento de efluente na seção do rio 39

Figura 5.1 - Fluxograma do algoritmo genético AG (Fonte: Adaptado de Loucks \& Beek, 2005)

Figura 5.2 - Fluxograma do algoritmo PSO (Fonte: Adaptado de Samarano e Prado, 2005)59

Figura 6.1 - Sistema atual para análise de outorga quantitativa e qualitativa 66

Figura 6.2 - Sistema de Suporte a Decisão proposto para análise de outorga quantitativa e qualitativa

Figura 6.3 - Fluxograma do SSD Outorga de Efluentes 68

Figura 6.4 - Estratégias para análise de outorga de efluentes presentes no SSD proposto 70

Figura 6.5-Fluxograma do SSD para otimização da outorga de efluentes. 80

Figura 7.1 - Localização da Bacia Hidrográfica do Rio Atibaia. 86

Figura 7.2 - Discretização da Bacia Hidrográfica do Rio Atibaia 87

Figura 7.3 - Perfil de DBO no rio Atibaia obtido com AG 90

Figura 7.4- Perfil de DBO no rio Atibaia obtido com PSO 91

Figura 7.5 - Perfil de DBO no rio Atibaia obtido com DE 91

Figura 7.6 - Perfil de OD no rio Atibaia obtido com AG 92

Figura 7.7 - Perfil de OD no rio Atibaia obtido com PSO...... 93

Figura 7.8 - Perfil de OD no rio Atibaia obtido com DE 93

Figura 7.9 - Perfil de DBO para os parâmetros médios obtidos para as 50 simulações com os algoritmos $\mathrm{AG}, \mathrm{PSO}$ e DE. 97

Figura 7.10 - Perfil de OD para os parâmetros médios obtidos para as 50 simulações com os algoritmos $A G$, PSO e DE. 98

Figura 7.11 - Comportamento da função objetivo para as 5000 gerações analisadas para 
estratégia $1 \mathrm{~A}$ e $\mathrm{B}$.....

Figura 7.14 - Perfil de OD e DBO, vazão do trecho e vazão de diluição para estratégia $1 \mathrm{~A}$ obtido com o AG.

Figura 7.15 - Perfil de OD e DBO, vazão do trecho e vazão de diluição para estratégia 1B obtido com o AG. 104

Figura 7.16 - Perfil de OD e DBO, vazão do trecho e vazão de diluição para estratégia $1 \mathrm{~A}$ obtido com o PSO.

Figura 7.17 - Perfil de OD e DBO, vazão do trecho e vazão de diluição para estratégia 1B obtido com o PSO.

Figura 7.18 - Perfil de OD e DBO, vazão do trecho e vazão de diluição para estratégia 1A obtido com o DE

Figura 7.19 - Perfil de OD e DBO, vazão do trecho e vazão de diluição para estratégia 1B obtido com o DE 105

Figura 7.20 - Distribuição dos custos das medidas de despoluição ao longo dos trechos e acumulada para a estratégia de outorga $1 \mathrm{~A}$ 106

Figura 7.21 - Distribuição dos custos das medidas de despoluição ao longo dos trechos e acumulada para a estratégia de outorga $1 \mathrm{~B}$ 106

Figura 7.22 - Comportamento da função objetivo para as 5000 gerações analisadas para estratégia $2 \mathrm{~A}$ e $\mathrm{B}$ 108

Figura 7.23 - Perfil de OD e DBO para os algoritmo AG, PSO e DE otimizando a estratégia 2 A 110

Figura 7.24 - Perfil de OD e DBO para os algoritmo AG, PSO e DE otimizando a estratégia 2 B 110

Figura 7.25 - Perfil de OD e DBO, vazão do trecho e vazão de diluição para estratégia 2 A obtido com o AG.

Figura 7.26 - Perfil de OD e DBO, vazão do trecho e vazão de diluição para estratégia 2 B obtido com o AG

Figura 7.27 - Perfil de OD e DBO, vazão do trecho e vazão de diluição para estratégia 2 A obtido com o PSO.

Figura 7.28 - Perfil de OD e DBO, vazão do trecho e vazão de diluição para estratégia 2 B obtido com o PSO.

Figura 7.29 - Perfil de OD e DBO, vazão do trecho e vazão de diluição para estratégia 2 A obtido com o DE 
Figura 7.30 - Perfil de OD e DBO, vazão do trecho e vazão de diluição para estratégia 2 B obtido com o DE

Figura 7.31 - Distribuição dos custos das medidas de despoluição ao longo dos trechos e acumulada para a estratégia de outorga $2 \mathrm{~A}$

Figura 7.32 - Distribuição dos custos das medidas de despoluição ao longo dos trechos e acumulada para a estratégia de outorga $2 \mathrm{~B}$

Figura 7.33 - Comportamento da função objetivo para as 5000 gerações analisadas para estratégia $3 \mathrm{~A}$ e $\mathrm{B}$

Figura 7.34 - Perfil de OD e DBO para os algoritmo AG, PSO e DE otimizando a estratégia 3 A 116

Figura 7.35 - Perfil de OD e DBO para os algoritmo AG, PSO e DE otimizando a estratégia 3B 117

Figura 7.36 - Perfil de OD e DBO, vazão do trecho e vazão de diluição para estratégia $3 \mathrm{~A}$ obtido com o AG.

Figura 7.37 - Perfil de OD e DBO, vazão do trecho e vazão de diluição para estratégia 3 B obtido com o AG

Figura 7.38 - Perfil de OD e DBO, vazão do trecho e vazão de diluição para estratégia 3 A obtido com o PSO.

Figura 7.39 - Perfil de OD e DBO, vazão do trecho e vazão de diluição para estratégia 3 B obtido com o PSO. 118

Figura 7.40 - Perfil de OD e DBO, vazão do trecho e vazão de diluição para estratégia 3 A obtido com o DE

Figura 7.41 - Perfil de OD e DBO, vazão do trecho e vazão de diluição para estratégia 3 B obtido com o DE 118

Figura 7.42 - Distribuição dos custos das medidas de despoluição ao longo dos trechos e acumulada para a estratégia de outorga $3^{\text {a }}$ 119

Figura 7.43 - Distribuição dos custos das medidas de despoluição ao longo dos trechos e acumulada para a estratégia de outorga 3B 119

Figura 7.44 - Perfil de DBO e OD obtido para cada estratégia de outorga analisada 121

Figura 7.45 - Perfil de qualidade, vazão no trecho e vazão de diluição no trecho para a Estratégia $1 \mathrm{~A}$ 122

Figura 7.46 - Perfil de qualidade, vazão no trecho e vazão de diluição no trecho para a Estratégia $2 \mathrm{~A}$ 
Figura 7.47 - Perfil de qualidade, vazão no trecho e vazão de diluição no trecho para a Estratégia $3 \mathrm{~A}$

Figura 7.48 - Distribuição dos custos das medidas de despoluição ao longo dos trechos e acumulada para a estratégia as estratégias $1 \mathrm{~A}, 2 \mathrm{~A}$ e $3 \mathrm{~A}$

Figura 7.49 - Parâmetros integrados na análise do SSD para outorga de efluentes 130

Figura 10.1 - Tela inicial do modelo habilitado para o modulo de calibração do modelo de qualidade

Figura 10.2 - Tela inicial do modelo habilitado para o modulo de otimização de lançamentos 145

Figura 10.3 - Tela de entrada de dados dos cursos d'água a serem simulados 146

Figura 10.4 - Botões para a entrada de dados e visualização de resultados 146

Figura 10.5 - Teta entrada de dados dos parâmetros dos algoritmos. 147

Figura 10.6 - Informações da cabeceira 147

Figura 10.7 - Dados de entrada de vazão natural, captações e lançamentos 148

Figura 10.8 - Dados de entrada características dos trechos e coeficientes de decaimento148 Figura 10.9 - Dados de entrada dos tipos de uso da bacia - Finalidades de uso 149

Figura 10.10 - Dados de entrada dos tipos de tratamento e respectivas funções de custo e eficiências de tratamento 149

Figura 10.11 - Tela de associação dos tipos de tratamentos com as finalidades de uso... 150 Figura 10.12 - Gráfico com perfil longitudinal para os parâmetros de qualidade d'água OD e DBO. 150

Figura 10.13 - Tela de apresentação dos resultados 151

Figura 10.14 - Resultados da função objetivo para o número de gerações 151

Figura 10.15 - Gráfico da função objetivo para as n gerações 152 


\section{LISTA DE TABELAS}

Tabela 3.1- Critérios adotados para outorga de captação de águas superficiais................ 20

Tabela 3.2 - Custos medidas de controle de carga difusa............................................. 30

Tabela 6.1- Valores típicos para a taxa de degradação da matéria orgânica $\left(\mathrm{k}_{\mathrm{d}}\right)$.................73

Tabela 6.2 - Equações para determinação do coeficiente de reaeração ............................. 74

Tabela 6.3- Funções de custos de implantação dos sistemas de tratamento de esgoto

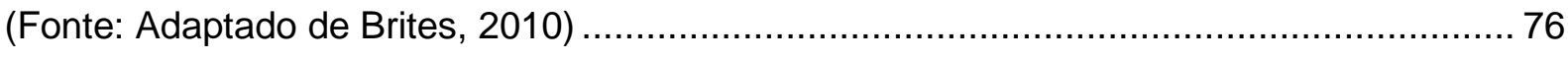

Tabela 7.1 - Parâmetros dos algoritmos analisados adotados para o estudo de caso ........ 88

Tabela 7.2 - Estações de qualidade da água utilizadas no estudo ................................... 88

Tabela 7.3 - Dados estatísticos dos valores da FO, obtidos para o AG, PSO e DE no Rio

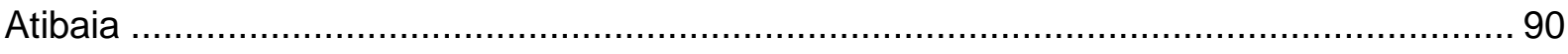

Tabela 7.4- Coeficientes obtidos nas 50 simulações com AG, PSO e DE no Rio Atibaia..... 95

Tabela 7.5- Resultados obtidos para a função objetivo (FO), custo global, vazão de diluição, violação da Lei Ambiental de efluentes e carga total remanescente para AG, PSO e DE na avaliação da alocação de carga no rio Atibaia - Estratégia de Outorga 1 ......................... 101

Tabela 7.6- Atendimento às demandas no Rio Atibaia - Estratégia de Outorga 1B.......... 102

Tabela 7.7- Resultados obtidos para a função objetivo (FO), custo global, vazão de diluição, violação da Lei Ambiental de efluentes e carga total remanescente para AG, PSO e DE na avaliação da alocação de carga no rio Atibaia - Estratégia de Outorga 2......................... 109

Tabela 7.8- Atendimento às demandas no Rio Atibaia - Estratégia de Outorga 2B.......... 109

Tabela 7.9- Resultados obtidos para a função objetivo (FO), custo global, vazão de diluição, violação da Lei Ambiental de efluentes e carga total remanescente para AG, PSO e DE na avaliação da alocação de carga no rio Atibaia - Estratégia de Outorga 3....................... 115

Tabela 7.10- Resultados obtidos para os trechos onde há lançamento de efluentes, pelo algoritmo AG, nas Estratégia de Outorga 1A (Sem Restrições), 2A (Isonomia entre os usuários) e 3A (Legislação Ambiental) para a concessão de outorga para o Rio Atibaia ... 126

Tabela 10.1 - Estações fluviométricas utilizadas no estudo ........................................... 153

Tabela 10.2 - Estações de qualidade da água utilizadas no estudo ............................... 153

Tabela 10.3 - Dados das estação de monitoramento de qualidade no Rio Atibaia ............. 154

Tabela 10.4 - Dados das estação de monitoramento de qualidade no Rio Atibaia.............. 154

Tabela 10.5 - Dados de entrada do modelo: comprimento do trecho, classe de 
enquadramento, limites para os coeficientes de qualidade da água e coeficientes de velocidade e profundidade para os trechos no Rio Atibaia........

Tabela 10.6- Dados de entrada do modelo - Captações, Lançamentos e finalidade de uso para os usuários d'água no Rio Atibaia e contribuição natural... 


\section{LISTA DE SIGLAS}

\begin{tabular}{|c|c|}
\hline AAGISA-PB & Agência de Águas, Irrigação e Saneamento do Estado da Paraíba \\
\hline AcquaNet & Sistema de Suporte à Decisão desenvolvido pelo LabSid \\
\hline $\mathrm{AE}$ & Algoritmo Evolutivo \\
\hline AG & Algoritmo Genético \\
\hline ALOC Server & Software de estrutura modular, web e georeferenciado \\
\hline ANA & Agência Nacional de Águas \\
\hline BMP's & Best Management Practices (Melhores Práticas de Manejo) \\
\hline CETESB & Companhia Ambiental do Estado de São Paulo \\
\hline $\mathrm{CNRH}$ & Conselho Nacional de Recursos Hídricos \\
\hline CONAMA & Conselho Nacional de Meio Ambiente \\
\hline CTPOAR & $\begin{array}{l}\text { Câmara Técnica de Integração de Procedimentos, Ações de Outorga e Ações } \\
\text { Reguladoras }\end{array}$ \\
\hline DAEE & Departamento de Águas e Energia Elétrica \\
\hline DBO & Demanda Bioquímica de Oxigênio \\
\hline $\mathrm{DE}$ & Differential Evolution \\
\hline DOS & Disk Operating System ou sistema operacional em disco \\
\hline DOU & Diário Oficial da União \\
\hline DPO & Diretoria de Procedimentos de Outorga e Fiscalização \\
\hline EUA & Estados Unidos da América \\
\hline $\mathrm{FO}$ & Função Objetivo \\
\hline IGAM & Instituto Mineiro de Gestão das Águas \\
\hline LabSid & Laboratório de Sistemas de Suporte a Decisões (USP) \\
\hline MMA & Ministério do Meio Ambiente \\
\hline Modelo WODA & Oxidation Deoxidation Assessment Model \\
\hline ModSim & Generalized River Basin Decision Support System and Network Flow Model \\
\hline NATURATINS-TO & Instituto Natureza do Tocantins \\
\hline OD & Oxigênio Dissolvido \\
\hline OTIS & One-Dimensional Transport with Inflow and Storage Model \\
\hline $\mathrm{pH}$ & Potencial Hidrogeniônico \\
\hline PNRH & Política Nacional de Recursos Hídricos \\
\hline PSO & Particle Swarm Optimization \\
\hline QUAL2E & Modelo de Qualidade das Águas \\
\hline $\mathrm{RH}$ & Recursos Hídricos \\
\hline RM1 & Modelo de alocação de vazão de diluição ao longo do corpo hídrico \\
\hline SECTMA-PE & Secretaria de Ciência, Tecnologia e Meio Ambiente de Pernambuco \\
\hline SEMARH-GO & Secretaria do Meio Ambiente e dos Recursos Hídricos de Goiás \\
\hline SEMAR-PI & Secretaria de Meio Ambiente e Recursos Hídricos do Piauí \\
\hline SEMA-RS & Secretaria Especial de Meio Ambiente Rio Grande do Sul \\
\hline
\end{tabular}




$\begin{array}{ll}\text { SEPLANTEC-SE } & \text { Secretaria do Estado do Planejamento, Habitação e do Desenvolvimento } \\ & \text { Urbano de Sergipe } \\ \text { SERHID-RN } & \text { Secretaria de Estado do Meio Ambiente e dos Recursos Hídricos do Rio } \\ & \text { Grande do Norte } \\ \text { SIG } & \text { Sistema de Informação Geográfico } \\ \text { SINGREH } & \text { Sistema Nacional de Gerenciamento de Recursos Hídricos } \\ \text { SISNAMA } & \text { Sistema Nacional de Meio Ambiente } \\ \text { SRH-BA } & \text { Secretaria de Recursos Hídricos da Bahia } \\ \text { SRH-CE } & \text { Secretaria de Recursos Hídricos da Ceará } \\ \text { SSD } & \text { Sistema de Suporte a Decisão } \\ \text { SSD - RB } & \text { Sistema de Suporte a Decisão (SSD) RB } \\ \text { SUDERHSA-PR } & \text { Superintendência de Desenvolvimento de Recursos Hídricos e Saneamento } \\ \text { U.S. EPA } & \text { Ambiental do Paraná } \\ \text { UASB } & \text { United States Environmental Protection Agency } \\ \text { USP } & \text { Upflow Anaerobic Sludge Blanket no Brasil Digestor Anaeróbio de Fluxo } \\ \text { VB.Net } & \text { Ascendente (DAFA) }\end{array}$




\section{LISTA DE SÍMBOLOS}

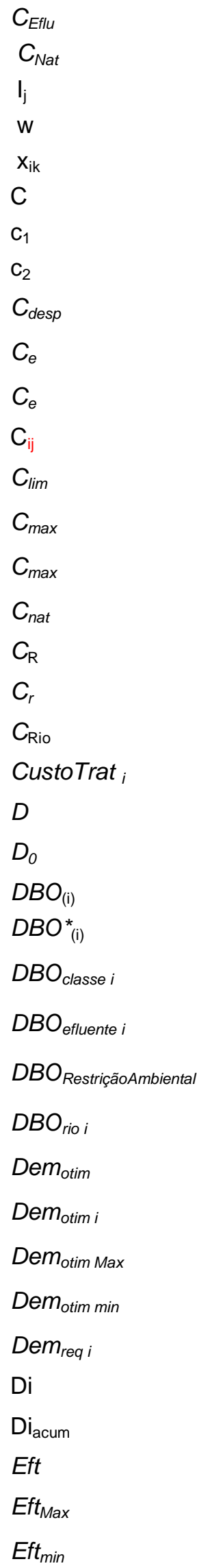

Concentração do efluente

Concentração natural afluente

Conjunto de todos os nós com arcos que terminam no nó j

Coeficiente de inércia (peso inercial)

Vetor corrente da partícula i

Custo das Medidas (U\$)

Parâmetros cognitivo PSO

Parâmetros social PSO

Concentração de determinado poluente (mg/L)

Concentração do efluente (mg/L)

Concentração do efluente (mg/L)

Custo (prioridade) da unidade de vazão que transita entre os nós i e j

Concentração limite da classe de enquadramento $(\mathrm{mg} / \mathrm{L})$

Concentração máxima permitida pela classe do rio ( $\mathrm{mg} / \mathrm{L})$

Concentração máxima permitida pela classe do rio (mg/L)

Concentração natural igual a concentração de pré-desenvolvimento ( $\mathrm{mg} / \mathrm{L})$

Probabilidade de cruzamento DE

Concentração no rio $(\mathrm{mg} / \mathrm{L})$

Concentração do rio (mg/L)

Custo de implantação do sistema de tratamento de efluente no trecho (i)

Déficit de oxigênio (mg/L)

Déficit inicial de oxigênio (mg/L)

Concentração calculada de DBO (mg/L)

Representa a concentração observada de DBO (mg/L)

Limite da classe de enquadramento do parâmetro de DBO do corpo d'água no trecho (i)

Concentração de DBO do efluente no trecho (i)

Limite máximo de concentração de DBO que pode ser lançada no corpo receptor segundo a legislação ambiental

Concentração de DBO do corpo d'água no trecho (i)

Demanda otimizada pelo algoritmo para a captação i

Demanda otimizada pelo algoritmo para o usuário no trecho (i)

Demanda máxima imposta para a captação i (Demanda requerida)

Demanda mínima imposta pelo gestor para a captação i

Demanda quantitativa requerida pelo usuário no trecho (i)

Demanda na seção i

Demanda acumulada de montante até a seção i

Eficiência de tratamento otimizada pelo algoritmo para o efluente i

Eficiência de tratamento máxima imposta pelo gestor para o efluente i

Eficiência de tratamento mínima imposta pelo gestor para o efluente i 


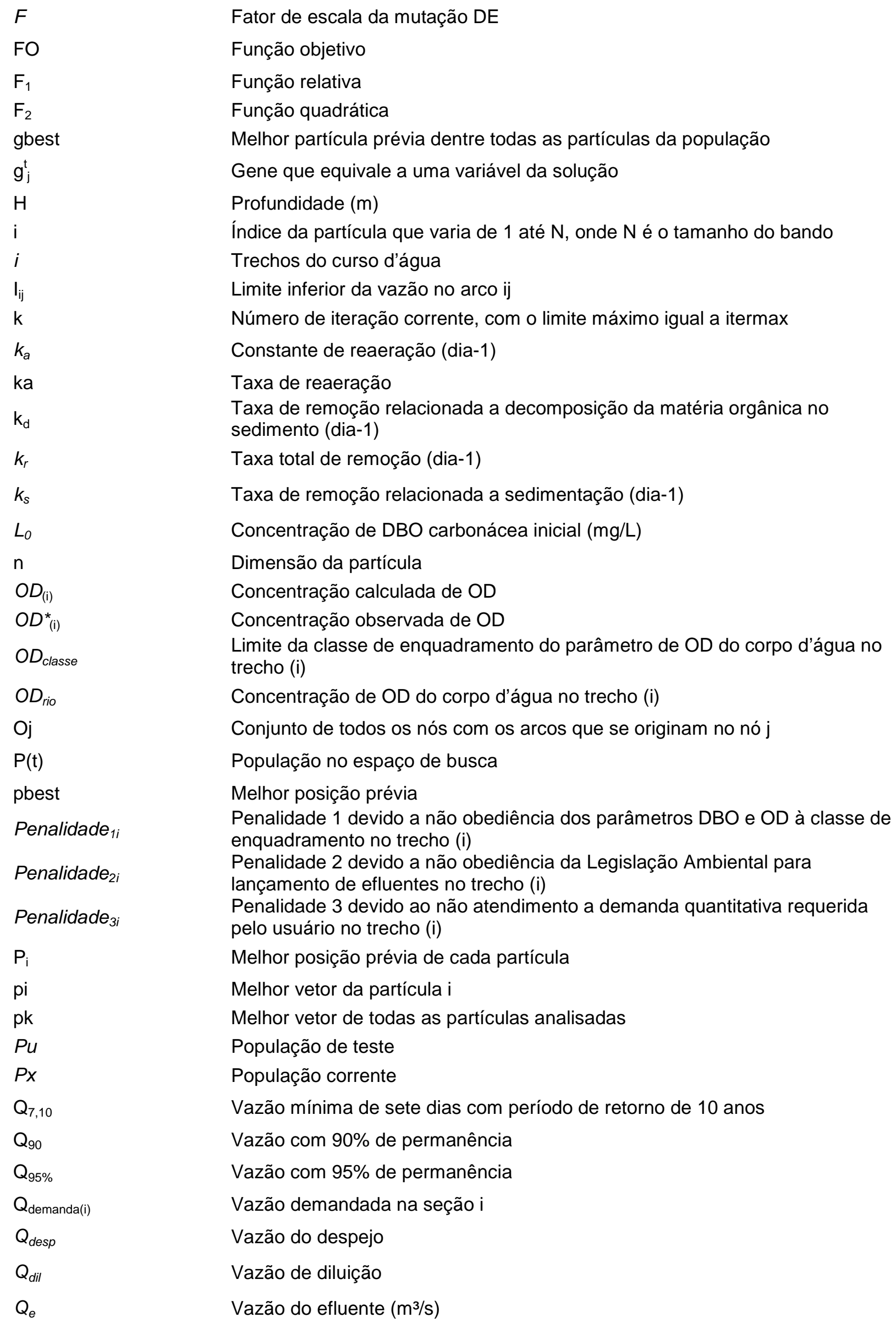




\begin{tabular}{|c|c|}
\hline$Q_{E f l u}$ & Vazão do efluente $\left(\mathrm{m}^{3} / \mathrm{s}\right)$ \\
\hline Qij & Vazão que transita do nó j \\
\hline$Q_{\text {nat }}$ & Vazão nautural $\left(\mathrm{m}^{3} / \mathrm{s}\right)$ \\
\hline$Q_{\text {outorgada }}$ & Vazão outorgada (m³/s) \\
\hline$Q_{\text {outorgada(i) }}$ & Vazão outorgada na seção i \\
\hline$Q_{r}$ & Vazão no rio (m³/s) \\
\hline$Q_{\text {Rio }}$ & Vazão no rio $\left(\mathrm{m}^{3} / \mathrm{s}\right)$ \\
\hline$Q_{x} \%$ & Vazão associada à permanência de $x \%$ no tempo \\
\hline$r_{0}, r_{1}, r_{2}$ & Índices de vetores \\
\hline$r_{1} e r_{2}$ & Valores randômicos distribuídos entre 0 e 1 \\
\hline$S_{i j}$ & Limite superior da vazão no arco ij \\
\hline$S L$ & Carga difusa de DBO ( $\left.\mathrm{g} / \mathrm{m}^{3} \mathrm{dia}\right)$ \\
\hline$U$ & Velocidade $(\mathrm{m} / \mathrm{s})$ \\
\hline $\mathrm{V}$ & Volume do escoamento destinado ao tratamento pela BMP $\left(\mathrm{ft}^{3}\right)$ \\
\hline $\mathrm{V}_{\mathrm{i}}$ & Velocidade ou taxa de variação da posição da partícula i \\
\hline$V_{i, g}$ & Vetor mutante \\
\hline w & Coeficiente de inércia (peso inercial) PSO \\
\hline$W_{A m b}$ & Peso aplicado a penalidade 3 de restrição ambiental para os lançamentos \\
\hline$w_{D B O}$ & Peso do parâmetro DBO (wdbo=1-wod) \\
\hline$W_{d e m}$ & Peso aplicado à penalidade 2 atendimento as demandas \\
\hline$w_{O D}$ & Peso do parâmetro OD aplicado para calibração automática \\
\hline$W_{q}$ & Peso aplicado a penalidade 1 atendimento a classe de enquadramento \\
\hline$x$ & Distância (m) \\
\hline$x$ & Capacidade de tratamento $\left(\mathrm{m}^{3} / \mathrm{s}\right)$ \\
\hline$X_{i}$ & Partícula i candidata à solução do problema \\
\hline $\mathrm{x}_{\mathrm{iN}}$ & Variável da solução \\
\hline$X_{r o, g}$ & Vetor com melhor valor da função objetivo \\
\hline$x_{i}^{t}$ & Cromossoma $x_{i}^{t}$, candidato à solução do problema de otimização \\
\hline y & Custo implantação sistema de tratamento $\left(\mathrm{R} \$ /\left(\mathrm{m}^{3} / \mathrm{s}\right)\right)$ \\
\hline
\end{tabular}




\section{INTRODUÇAO}

A água é essencial para a manutenção da vida e seu uso racional tem um papel vital para a manutenção dos processos hidrológicos que garantem a qualidade e volume dos cursos d'água. Todas as atividades desenvolvidas dentro de uma bacia hidrográfica dependem da água para sua manutenção, seja a agricultura, a pesca, a indústria, o comércio, a geração de energia, o turismo, assim como, atividades recreativas e diluição de efluentes.

A questão da água e sua disponibilidade em quantidade e qualidade é um assunto presente em grupos de discussões e vem ganhando cada vez mais destaque em pesquisas e na mídia. Isto se deve a eminente escassez do recurso, que muitas vezes pode estar relacionada com o mau uso dos recursos naturais ou ainda com as condições climáticas e morfológicas, o que ocasiona sérios comprometimentos sócio-econômicos para a bacia hidrográfica. Ao se tratar do processo de gestão integrada de recursos hídricos de uma região, fatores como concentração populacional e atividades econômicas devem ser considerados, pois isto acarreta em demanda hídrica, seja para atender as necessidades dos usuários ou para a dissolução das cargas poluentes resultantes das atividades desenvolvidas.

O Brasil é um país que apresenta alta disponibilidade hídrica, no entanto, a distribuição espacial dos recursos hídricos, em muitas regiões, não coincide com a concentração das demandas e a localização dos grandes centros urbanos. Alia-se ainda a esta má distribuição do recurso o problema relacionado à poluição hídrica, principalmente em locais próximos às regiões metropolitanas.

Neste cenário de escassez surgem os principais conflitos de usos, uma vez que a disponibilidade hídrica é inferior à demanda para atender aos múltiplos usos. O conhecimento da disponibilidade hídrica é fundamental para o processo de gestão. Segundo Porto (2002), o processo de alocação da água somente pode existir a partir do conhecimento da disponibilidade hídrica da bacia, objeto de gestão. A disponibilidade hídrica é função de duas variáveis, a quantidade e a qualidade da água disponível. Um determinado uso somente será atendido se, além da quantidade necessária para satisfazê-lo, a qualidade for adequada àquele mesmo uso.

O processo de gestão de recursos hídricos no Brasil conta com um marco legal que dispõe sobre a Política Nacional de Recursos Hídricos e cria o Sistema Nacional de Gerenciamento de Recursos Hídricos, a Lei 9433 de 8 de janeiro de 1997. Entre os avanços apresentados pela Lei 9.433/97 está a gestão sistemática dos recursos hídricos, sem dissociação dos aspectos de quantidade e qualidade; a integração da gestão de recursos 
hídricos com a gestão ambiental e a articulação da gestão de recursos hídricos com a do uso do solo. Estes aspectos são fundamentais para a efetivação do desenvolvimento sustentável dos recursos hídricos, a qual envolve o atendimento das demandas, a preservação do meio ambiente e o desenvolvimento econômico da região.

A Política Nacional de Recursos Hídricos consta de cinco instrumentos de gestão para sua implementação, entre os quais estão: o plano de recursos hídricos, o enquadramento dos corpos d'água, a outorga de direito de uso da água, a cobrança pelo uso do recurso hídrico e o sistema integrado de informações.

A outorga de direitos de uso da água, objeto de estudo da presente tese, tem como função a regulamentação que estabelece o controle das demandas, lançamentos e da disponibilidade hídrica, tanto em aspectos quantitativos como qualitativos da bacia hidrográfica, bem como assegurar o direito de acesso à água.

A metodologia utilizada atualmente pela maioria dos estados brasileiros no processo de outorga é realizada através de uma análise de balanço hídrico. Neste processo a vazão outorgável é igual à vazão de referência local ou uma porcentagem deste valor subtraído dos valores já outorgados a montante, também é avaliado se o novo valor outorgado para este local não prejudicará as outorgas já concedidas a jusante.

A solução de problemas complexos em recursos hídricos, como é o caso da outorga do direito de uso d'água, necessita de análises mais amplas, as quais já não envolvem apenas problemas de balanço hídricos simples ou equações matemáticas de transporte de poluentes, mas sim atividades de gestão. Nestas atividades os gestores necessitam utilizar as informações disponíveis, sejam estas obtidas por cadastros, dados observados ou através de simulações para estudar as melhores alternativas, visando o uso racional do recurso hídrico e o desenvolvimento econômico da bacia hidrográfica.

O desenvolvimento de um sistema de gestão que estabeleça diretrizes para o planejamento e disciplinamento dos usos é fundamental para efetivação da gestão de recursos hídricos, tanto no que diz respeito aos critérios a serem aplicados, quanto às análises de quantidade e qualidade da água ao longo dos cursos d'água. A integração destes critérios visa atender as demandas de uso e ao mesmo tempo a proteção ambiental.

Na literatura é possível identificar alguns trabalhos que tratam de outorga dos direitos de uso da água com ênfase na integração do lançamento de efluentes no processo. Porém, existem grandes desafios a serem enfrentados como é o caso de metodologias que integrem quantidade e qualidade da água nas análises de outorga, assim como a inserção das vazões de diluição ao balanço de disponibilidade hídrica, atualmente, uma das principais barreiras a ser vencida no gerenciamento dos recursos hídricos.

As situações reais enfrentadas pelos órgãos gestores são complexas, considerado os processos ocorridos no próprio corpo d'água, onde diferentes tipos de despejos são 
lançados no rio, contendo diversos poluentes, cada um com diferentes taxas de autodepuração e exigindo diferentes vazões de diluição para o atendimento das classes de uso.

Usualmente não é possível resolver estes problemas contando apenas com a capacidade de diluição do corpo receptor. Assim sendo, recorre-se ao tratamento dos despejos e com isto outros problemas são observados, como por exemplo, onde tratar, com que eficiência e ainda a que custo. O impacto econômico deve ser incluído nas análises de outorga de efluentes, pois o mesmo pode não ser compatível com a disponibilidade financeira dos usuários da bacia. Esta situação resulta na fuga destes usuários para bacias com maior disponibilidade hídrica para diluição dos efluentes, trazendo prejuízos sociais e econômicos para região.

Tamanhas dificuldades e complexidades dos aspectos envolvidos na análise de outorga de lançamento de efluentes explicam a situação que paralisa os órgãos gestores diante dos problemas enfrentados em bacias com escassez de água. Esta constatação motivou o desenvolvimento do SSD proposto nesta tese, o qual considera a integração dos aspectos de quantidade e qualidade na otimização da alocação de carga poluidora e as demandas consuntivas visando a minimização dos custos de implantação das estações de tratamento de efluentes e o atendimento à classe de enquadramento dos corpos d'água. $\mathrm{O}$ SSD possibilita avaliar diferentes estratégias de outorga como a isonomia dos usuários da bacia, a avaliação das exigências ambientais para o lançamento de efluentes, assim como analisar as outorgas restringindo ou flexibilizando as eficiências de tratamento de cada usuário ou para cada finalidade de uso.

Desta forma, o SSD considera integradamente os processos ocorridos no corpo hídrico, fornecendo alternativas de controle das cargas poluentes condizentes com a realidade de cada bacia hidrográfica. $A$ análise integrada das técnicas de tratamento de efluentes e dos custos de implantação propicia a efetivação da outorga de lançamento de efluentes, uma vez que a tomada de decisão será sobre critérios factíveis com a disponibilidade financeira da bacia hidrográfica.

Tendo em vista o importante papel da outogra de efluentes no processo de gestão, através do disciplinamento dos usos dos recursos hídricos e de sua atuação sobre o controle da poluição hídrica ao estabelecer restrições de uso e remoção da carga poluente afluente ao corpo d'água, o SSD proposto, com as estratégias para auxiliar a tomada de decisão, contribuirá para a efetivação do instrumento de outorga e, consequentemente, para a gestão de recursos hídricos no país. 


\section{OBJETIVO}

Esta tese tem por objetivo fornecer subsídios para a gestão sustentável dos recursos hídricos, através do desenvolvimento de um Sistema de Suporte a Decisão (SSD) que auxilie a aplicação da outorga de lançamento de efluentes, instrumento de gestão da Política Nacional de Recursos Hídricos (Lei 9433/97). O SSD visa a análise integrada dos aspectos de quantidade e qualidade da água, o qual permitirá ao tomador de decisão ponderar de forma conjunta a outorga de quantidade e a outorga de efluentes. O Sistema de Suporte a Decisão desenvolvido utiliza em seu processo de análise algoritmos evolucionários para a otimização do processo de alocação de demanda e de carga efluente, visando a maximização dos usos e a minimização dos custos das medidas de tratamento de efluentes respeitando os limites impostos pela classe de enquadramento dos corpos d'água. O SSD considera entre suas estratégias de análise o atendimento da legislação ambiental para o lançamento de efluentes, a isonomia entre os usuários, o atendimento aos padrões de qualidade estabelecidos pelo enquadramento dos corpos hídricos e as restrições impostas pelo órgão gestor aos usuários ou as finalidades de uso.

\subsection{Objetivos específicos}

A seguir serão apresentadas as principais etapas do desenvolvimento da tese:

- Estudo da bibliografia existente sobre as metodologias utilizadas para análise da outorga de efluentes e o panorama atual do instrumento de outorga de Recursos Hídricos no Brasil;

- Estudo dos algoritmos evolucionários Algoritmos Genéticos (AG), Particle Swarm Optimization (PSO) e Differential Evolution (DE) para a otimização da outorga de efluentes;

- Desenvolvimento do Sistema de Suporte a Decisão para análise da outorga de lançamento de efluentes, e desenvolvimento de estratégias de outorga;

- Aplicação do SSD para estudo de caso na Bacia do Rio Atibaia/SP;

- Análise do resultado otimizado obtido para as diferentes estratégias de outorga de lançamento de efluentes propostas;

- Comparação e discussão dos resultados obtidos para as diferentes estratégias de outorga;

- Analise crítica do Sistema de Suporte da Decisão proposto e seu papel para a efetivação do instrumento de outorga de lançamento de efluentes. 


\subsection{Justificativa}

Os avanços obtidos na gestão de recursos hídricos no Brasil nas últimas décadas são evidentes, onde destaca-se a criação da Política e do Sistema Nacional de Gerenciamento de Recursos Hídricos com a promulgação da Lei Federal 9.433 em 8 de janeiro de 1997.

Entre os objetivos da Política Nacional de Recursos Hídricos está o de assegurar à atual e às futuras gerações a necessária disponibilidade de água, em padrões de qualidade adequados para atender as demandas dos diversos setores usuários.

A Lei 9.433/97 introduziu conceitos fundamentais para o processo de gestão, entre os quais destaca-se o estabelecimento dos instrumentos de gestão para sua efetivação. No entanto, observa-se no cenário atual que existem algumas dificuldades para implementação dos instrumentos de gestão de recursos hídricos, as quais se relacionam às questões metodológicas e conceituais. Outra dificuldade observada é a implementação dos instrumentos de forma integrada, a qual garante a obtenção dos objetivos da Lei 9.433/97 e a efetivação das ações para o controle da poluição.

Dentro deste enfoque de controle de poluição, o instrumento de outorga de efluentes tem o proeminente papel de controlar e disciplinar os usos, buscando o equilíbrio entre o atendimento das demandas de uso e a manutenção dos padrões de qualidade do corpo hídrico. Apesar da evidente importância deste instrumento, sua implementação ainda é restrita, onde a complexidade dos aspectos envolvidos no processo decisório, junto aos órgãos gestores, são os principais responsáveis por esta situação. Desta forma, torna-se fundamental o desenvolvimento de um Sistema de Suporte a Decisão que auxilie o processo, através do estabelecimento de estratégias para o planejamento e disciplinamento dos usos da água.

O SSD proposto nesta tese para outorga de lançamento de efluentes buscou integrar em uma plataforma única de forma otimizada os aspectos relevantes para a tomada de decisão. A contribuição do SSD desenvolvido está na sistematização dos dados, com a integração otimizada da quantidade e qualidade da água, inserção da análise financeira das alternativas e a formulação de estratégias para a análise da concessão da outorga de efluentes, em uma plataforma computacional eficiente, de fácil entendimento e capaz de produzir resultados direcionados para o processo de gestão. Esta análise integrada e otimizada dos aspectos inseridos no SSD é a principal contribuição deste estudo.

O SSD proposto, através de suas considerações e estratégias, contribuirá de forma eficiente para a efetivação do instrumento de outorga de efluentes e, consequentemente, para o sistema de gestão de recursos hídricos no país. 


\section{OUTORGA DE RECURSOS HÍDRICOS}

O direito de uso ou de posse da água é um tema polêmico desde a antiguidade, onde já existiam regras para disciplinar e até mesmo restringir o uso d'água. Na Roma antiga, já existiam leis de direito de uso, onde esses direitos eram independentes da propriedade da terra e duravam tanto quanto fosse a continuidade do uso.

No Brasil, a outorga de direito de uso dos recursos hídricos é um dos instrumentos de gestão da Política Nacional de Recursos Hídricos, definidos pela Lei 9433/97. A outorga de direito de uso possui um importante papel no gerenciamento dos recursos hídricos, uma vez que representa um instrumento de comando e controle, quantitativo e qualitativo, proporcionando a distribuição justa e equilibrada desse recurso. Através da outorga é possível garantir o efetivo exercício dos direitos de acesso aos recursos hídricos por parte dos usuários interessados, assim como minimizar os conflitos entre os diversos setores de usuários.

\subsection{Panorama da Outorga no Brasil}

O instrumento de outorga de direito de uso d'água vem sendo aplicado em diversas bacias brasileiras, agindo como mediador dos conflitos pela disputa dos recursos hídricos. Apesar da evolução do número de outorgas concedidas no país, muitas dificuldades estão presentes na implementação do instrumento de outorga de direito de uso da água, sejam estas de caráter técnico ou conceitual. A necessidade pelo desenvolvimento de novas metodologias e ferramentas para a análise, pode ser observado pelo interesse no desenvolvimento de estudos técnicos e aplicações que abordam o assunto da outorga de $\mathrm{RH}$ pela comunidade científica. A seguir são apresentados alguns trabalhos que mostram a evolução deste tema no contexto nacional, os quais abordam estudos conceituais, critérios e aplicações: Silva \& Lanna (1996), Kelman (1997), Ferraz \& Braga (1998), Cruz et al. (1999), Rodrigues \& Porto (1999), Paiva \& Ribeiro (2000), Rodrigues (2000), Medeiros et al. (2001), Ribeiro \& Lanna (2003), Rodrigues \& Porto (2003), Machado et al. (2003), Garcia et al. (2007), Nahon et al. (2009).

No relatório Conjuntura dos Recursos Hídricos no Brasil 2009 (ANA, 2009) foi apresentado um panorama da outorga de uso dos recursos hídricos. Este panorama geral mostrou um comparativo entre a vazão total outorgada no Brasil em 2004 e em 2007. Neste período foi observado um aumento de quase $60 \%$ no valor total outorgado (de 2.304 para $3.520 \mathrm{~m} / \mathrm{s}$ ). O número total de outorgas emitidas no país era 95.107 ao final de $2004 \mathrm{e}$ 135.680 ao final de 2007 , verificando-se um aumento de 40.573 novas outorgas emitidas 
nesse período, o que corresponde a um acréscimo em $42 \%$ no número total de outorgas. No relatório Conjuntura dos Recursos Hídricos no Brasil de 2010 (ANA, 2010) foi apresentado que o número total de outorgas emitidas no país no final de 2009 era 162.208, representando uma vazão total de $5.374 \mathrm{~m}^{3} / \mathrm{s}$. Dessa forma, verificou-se um aumento de 26.528 novas outorgas desde 2007, com um acréscimo em termos de vazão outorgada de $1.558 \mathrm{~m}^{3} / \mathrm{s}$. Destaca-se que existe um aumento significativo das outorgas entre o período de 2004 e 2010, o que sinaliza para o fortalecimento do instrumento nos estados e órgãos gestores. A Figura 3.1 apresenta a evolução das outorgas emitidas no país.

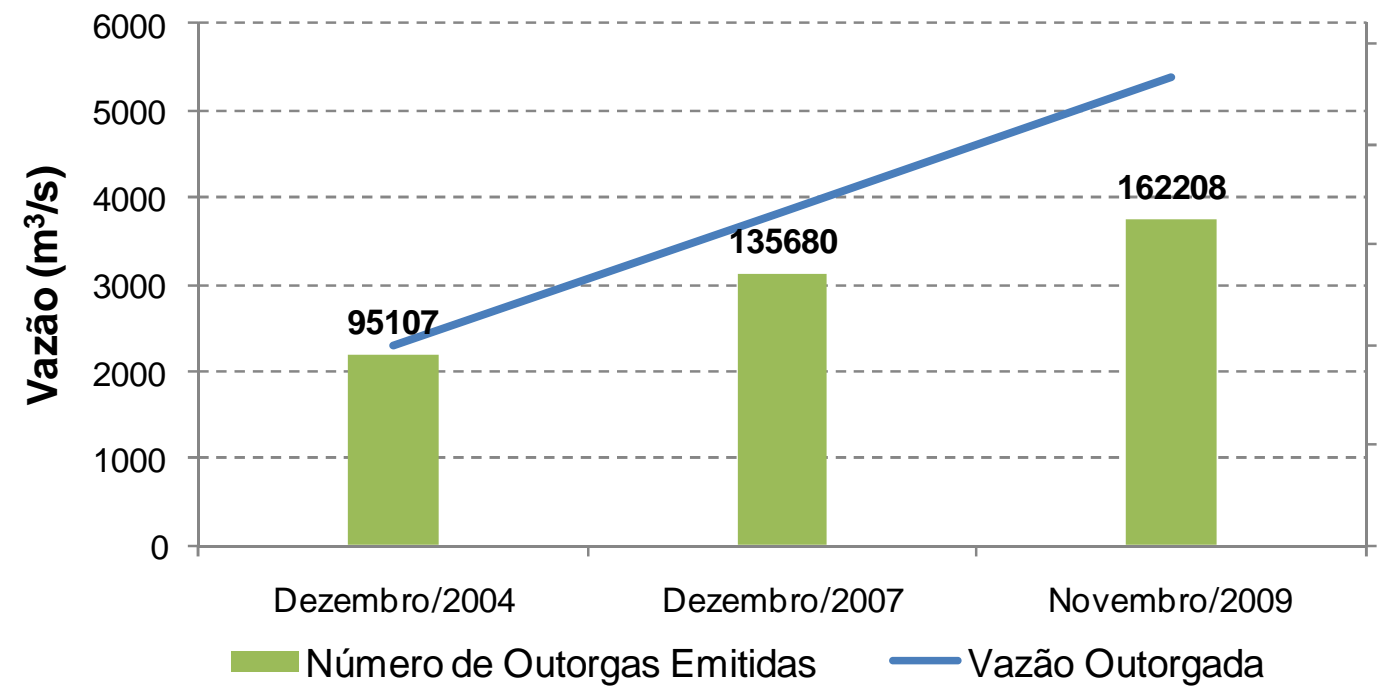

Figura 3.1 - Evolução do quadro geral de outorgas emitidas no país (Fonte: ANA, 2010)

Os números apresentados nos relatórios Conjuntura dos Recursos Hídricos no Brasil de 2009 e 2010 demonstraram o crescimento do número de outorga e, consequentemente, a efetivação do instrumento no Brasil. Apesar do crescimento das outorgas concedidas existe um longo caminho a ser percorrido pelos órgãos gestores para a sistematização do processo de concessão de outorga, pois se observa que os órgãos gestores apresentam dificuldades metodológicas na aplicação do instrumento e ainda ocorrerem paralisações nas emissões de outorga em bacias críticas, onde a demanda supera a disponibilidade.

O problema da disponibilidade hídrica está presente em diversas bacias hidrográficas brasileiras, podendo ser constatado no estudo realizado pela Agência Nacional de Águas (Conjuntura dos Recursos Hídricos no Brasil 2009 - ANA) que avaliou o balanço entre disponibilidade e demanda de recursos hídricos mediante a análise da razão entre a vazão de retirada para os usos consuntivos e a disponibilidade hídrica. As faixas de classificação deste índice foram definidas iguais ao índice de retirada de água ou water exploitation índex utilizado pela European Environment Agency e as Nações Unidas. Este índice é o quociente entre a retirada total anual e a vazão média de longo período, onde valores acima de 10\% 
são considerados preocupantes (gerenciamento é indispensável, exigindo a realização de investimentos médios), acima de $20 \%$ situação crítica (intensa atividade de gerenciamento e grandes investimentos) e maior que $40 \%$ situação muito crítica. Valores a baixo de $10 \%$ são considerados confortáveis e abaixo de $5 \%$ excelentes.

Como resultados dessa análise as regiões Amazônica, Paraguai, Tocantins-Araguaia e Atlântico Nordeste Ocidental possuem situações bastante confortáveis quanto à relação demanda/disponibilidade, com mais de $88 \%$ de seus rios principais classificados como "excelente" e "confortável” . Por outro lado, as regiões que se encontram em situação de risco quanto ao balanço hídrico são as regiões hidrográficas do Atlântico Nordeste Oriental, Atlântico Leste, Atlântico Sul e São Francisco, com 91\%, 70\%, 59\% e 44\%, respectivamente, de seus principais rios classificados com situação "muito crítica" , "crítica” , ou "preocupante" (ANA, 2009). Este estudo mostrou que o Brasil possui uma alta disponibilidade hídrica, com uma grande oferta global de recursos hídricos. No entanto, este panorama pode ser alterado quando se analisam as regiões hidrográficas de forma individual e assim observa-se que em determinadas bacias hidrográficas a analise apenas da oferta do recurso não é suficiente para avaliar as condições de atendimento dos usos requeridos.

No mesmo estudo (ANA, 2009), buscou-se avaliar da situação da qualidade das águas, para isto foi realizada uma estimativa das cargas de esgoto doméstico urbano dos municípios brasileiros e da capacidade de assimilação dessas cargas pelos corpos d'água, considerando os rios enquadrados em classe 2, segundo a Resolução CONAMA 357/05. A carga assimilável pelo corpo hídrico foi estimada multiplicando-se a vazão disponível pela concentração de $5 \mathrm{mg} / \mathrm{L}$ de DBO (classe 2) e transformando-a em toneladas de $\mathrm{DBO}_{5,20 / \text { dia. }}$. Para a estimativa da capacidade de assimilação dos rios, os valores de carga de esgoto doméstico foram divididos pelas cargas assimiláveis calculadas para as vazões médias e disponíveis. Assim, os valores superiores a 1 indicaram que a carga orgânica lançada é superior a carga assimilável, os valores inferiores a 1 indicaram que a carga orgânica lançada é inferior a carga assimilável.

Observou-se que nos rios com baixa disponibilidade hídrica, principalmente os localizados na região do semi-árido, o problema de assimilação de carga orgânica está associado às baixas vazões dos corpos receptores. As regiões hidrográficas do Atlântico Nordeste Oriental, Atlântico Leste e Parnaíba foram as que apresentaram as condições mais críticas para a assimilação dos esgotos domésticos, devido à localização destas em regiões semiáridas, as quais constam de rios intermitentes que possuem baixa capacidade de assimilação de carga orgânica. 
O problema de disponibilidade hídrica é complexo e presente em diversas bacias hidrográficas, destacando-se a necessidade de atividades de gestão, tendo em vista quantificar os problemas e minimizar os custos dos impactos provocados. Os órgãos gestores estaduais, assim como a ANA a nível federal, buscam resolver os entraves do processo de outorga, mas o que se pode concluir é que existe um caminho longo a ser percorrido tanto a nível metodológico como a nível conceitual, como se observa nos exemplos dos órgãos gestores de São Paulo e Minas Gerais.

No estado de São Paulo, a Diretoria de Procedimentos de Outorga e Fiscalização DPO do DAEE enfrenta problemas para a concessão de outorga de direito de uso da água em bacias críticas. Quando uma bacia hidrográfica atinge o estado de criticidade o processo é paralisado e não são concedidas novas outorgas para a bacia em questão. Esse tipo de critério acaba excluindo os novos usuários do sistema de outorga, e provocando, mesmo que indiretamente, a exclusão do usuário do sistema, o qual pode ser impulsionado a utilizar o recurso sem estar devidamente cadastrado e quantificado pelo órgão outorgante.

No Estado de Minas Gerais, o IGAM, órgão gestor, apresenta outra metodologia para bacias críticas. Quando uma bacia é considerada crítica todos os usuários da bacia são comunicados e suas outorgas suspensas e, assim, os usuários necessitam solicitar uma outorga coletiva para esta bacia. O IGAM monitora o comportamento da bacia através de uma estação de monitoramento no exutório da mesma, evitando que os valores de uso d'água permitidos sejam excedidos. Cabe ao comitê de bacia resolver possíveis conflitos entre os usuários desta outorga coletiva.

Para os dois casos citados, São Paulo e Minas Gerais, existem diversas dificuldades de gerenciamento, pois no primeiro a paralisia total do processo trás prejuízos sociais e econômicos para a bacia hidrográfica. No segundo caso, as dificuldades de gestão e fiscalização podem prejudicar a harmonia entre os usuários da bacia hidrográfica, acarretando em conflitos de uso.

Como visto nesta análise do panorama do instrumento de outorga do direito de uso d'água no Brasil, ainda existem muitas dificuldades na sua implementação, sejam elas relacionadas aos critérios de outorga ou à carência de ferramentas que auxiliem o processo de análise de forma clara e eficiente. Quanto a outorga de lançamento de efluentes observase que muitos dos órgãos gestores não avaliam os impactos de forma sistematizada ao longo dos cursos d'água, ficando as análises penas para o cumprimentos das exigências do órgão ambiental. Esta situação se deve principalmente pela falta de mecanismos e ferramentas de fácil entendimento e análise que possibilitem avaliar a outorga de lançamento de efluentes de forma integrada no processo decisório.

Tendo em vista as dificuldades enfrentadas pelos órgãos gestores e a falta de metodologia para a análise da outorga qualitativa de $\mathrm{RH}$, este estudo visa desenvolver um 
sistema de suporte a decisão que auxilie o órgão gestor. A ferramenta proposta levará em consideração aspectos importantes no processo de outorga, tais como análise conjunta dos aspectos de quantidade e qualidade da água, a otimização da alocação das demandas e das cargas efluentes, assim como, a inserção da função custo tendo em vista a minimização dos custos para o tratamento das cargas visando a manutenção das concentrações limites no corpo receptor estabelecidas pelo enquadramento dos corpos d'água. Estes aspectos são essenciais no sistema de gestão de recursos hídricos, pois permitem o desenvolvimento sustentável da região, uma vez que permite o desenvolvimento econômico e a manutenção da qualidade da água compatível para atender aos múltiplos usos.

\subsubsection{Aspectos Legais Relacionados à Outorga de Direito de Uso dos Recursos} Hídricos

A primeira legislação brasileira específica para os recursos hídricos surgiu em 1934 com o Código das Águas, através do Decreto ํㅜ 24.643, de 10 de julho, publicado no DOU de 24 de julho de 1934. Esse Decreto Federal conferiu condições para o aproveitamento da água superficial, em particular a geração de energia elétrica.

Através de seu Art. 43 o Código das Águas cria o instrumento de outorga através da necessidade de autorização administrativa das águas públicas destinadas à agricultura, indústria e higiene.

Em 1972, o Estado de São Paulo, através do Decreto Estadual №. 52.636 de 03/12/1972, estabeleceu ao Departamento de Águas e Energia Elétrica (DAEE) a atribuição de fazer cumprir o Código de Águas de 1934. A partir daí foram aprovadas as primeiras outorgas de uso dos recursos hídricos.

A Constituição Federal, em 1988, extinguiu o domínio privado das águas ao considerar que todas as águas são públicas e estão sob o domínio da União ou dos Estados, e atribuiu à União instituir o Sistema Nacional de Gerenciamento de Recursos Hídricos e definir os critérios de outorga de direito de uso. Em virtude do estabelecido na Constituição Federal, e nas decorrentes Constituições Estaduais, alguns estados voltaram seus esforços para a elaboração das respectivas leis de recursos hídricos.

O estado de São Paulo, em 1991, incorporou estes princípios na primeira política estadual de recursos hídricos (Lei 7663/91), que estabeleceu diretrizes similares à Política Nacional ao mencionar entre seus objetivos assegurar os usos múltiplos da água, instituindo o sistema estadual com colegiados participativos, e definindo o enquadramento como seu instrumento de planejamento (LEWWESTEIN, 2000). 
Em sequência, no mês de julho de 1992, foi a vez do Estado do Ceará, seguido pelo Distrito Federal, em julho de 1993. No ano seguinte, Minas Gerais, Santa Catarina e Rio Grande do Sul sancionaram suas leis de recursos hídricos, nos meses de junho, novembro e dezembro, respectivamente. Em1995, os estados de Sergipe e da Bahia promulgaram suas leis e, em 1996, Rio Grande do Norte e Paraíba (MMA, 2006).

Em 8 de janeiro de 1997 foi sancionada a Lei no 9.433 que instituiu a Política Nacional de Recursos Hídricos e criou o Sistema Nacional de Gerenciamento de Recursos Hídricos.

A Lei 9.433/97 contribuiu significativamente para o crescimento e ordenamento do planejamento dos recursos hídricos. A Lei estabelece os seguintes fundamentos da Política Nacional de Recursos Hídricos (Art. 1ํ):

I. a água é um bem de domínio público;

II. a água é um recurso natural limitado, dotado de valor econômico;

III. em situações de escassez, o uso prioritário dos recursos hídricos é o consumo humano e a dessedentação de animais;

IV. a gestão dos recursos hídricos deve sempre proporcionar o uso múltiplo das águas;

V. a bacia hidrográfica é a unidade territorial para implementação da Política Nacional de Recursos Hídricos e atuação do Sistema Nacional de Gerenciamento de Recursos Hídricos;

VI. a gestão dos recursos hídricos deve ser descentralizada e contar com a participação do Poder Público, dos usuários e das comunidades.

Conforme o Art.2ํㅡ, da Lei no 9.433, são objetivos da Política Nacional de Recursos Hídricos:

I. assegurar à atual e às futuras gerações a necessária disponibilidade de água, em padrões de qualidade adequados aos respectivos usos;

II. a utilização racional e integrada dos recursos hídricos, incluindo o transporte aquaviário, com vistas ao desenvolvimento sustentável;

III. a prevenção e a defesa contra eventos hidrológicos críticos de origem natural ou decorrentes do uso inadequado dos recursos naturais.

A Lei no 9.433 estabelece, no seu Artigo 3ํㅡㄹ as seguintes diretrizes gerais de ação para a sua implementação:

I. a gestão sistemática dos recursos hídricos, sem dissociação dos aspectos de quantidade e qualidade;

II. a adequação da gestão de recursos hídricos às diversidades físicas, bióticas, demográficas, econômicas, sociais e culturais das diversas regiões do País; 
III. a integração da gestão de recursos hídricos com a gestão ambiental;

IV. a articulação do planejamento de recursos hídricos com o dos setores usuários e com os planejamentos regional, estadual e nacional;

V. a articulação da gestão de recursos hídricos com a do uso do solo;

VI. a integração da gestão das bacias hidrográficas com a dos sistemas estuarinos e zonas costeiras.

Para alcançar os objetivos, a lei define cinco instrumentos de gestão dos recursos hídricos (Lei n॰9.433, Art. 5):

I. os planos de recursos hídricos;

II. o enquadramento dos corpos de água em classes, segundo os usos preponderantes da água;

III. a outorga dos direitos de uso de recursos hídricos;

IV. a cobrança pelo uso de recursos hídricos;

V. o sistema de informações sobre recursos hídricos.

A Lei no 9.433 representou um marco fundamental no processo de mudança do ambiente institucional regulador dos recursos hídricos no Brasil, levando à criação do Conselho Nacional de Recursos Hídricos em 1998, e da Agência Nacional de Águas em 2000.

Dentre as atribuições do Conselho Nacional de Recursos Hídricos, estabelecidas pela Lei Federal 9.433/97, está o estabelecimento de critérios gerais para as outorgas de direito de uso de recursos hídricos.

Conforme o Caderno de Recursos Hídricos emitido pela ANA (2005) as resoluções emitidas pelo Conselho Nacional de Recursos Hídricos para implementação da outorga são:

- Resolução CNRH no 07/2000 de 21 de junho de 2000: tem a finalidade de instituir a Câmara Técnica de Integração de Procedimentos, Ações de Outorga e Ações Reguladoras - CTPOAR, com as seguintes atribuições:

I. propor diretrizes para integração de procedimentos entre as instituições responsáveis por ações de outorgas e ações reguladoras ligadas a recursos hídricos;

II. propor ações conjuntas entre as instituições, visando otimizar os procedimentos relacionados com assuntos afins;

III. propor diretrizes e ações conjuntas para soluções de conflitos nos usos múltiplos dos recursos hídricos;

IV.propor ações mitigadoras e compensatórias e,

V. as competências constantes do Regimento Interno do $\mathrm{CNRH}$ e outras que vierem a ser delegadas pelo seu Plenário. 
- Resolução CNRH no 91/08 de 5 de novembro de 2008: estabelece os procedimentos para implementação do enquadramento de corpos de água superficiais e subterrâneos em classes, segundo os usos preponderantes. Portanto, esta resolução torna-se importante para o processo de outorga uma vez que o enquadramento deve ser considerado na análise dos pedidos de outorga para lançamento de efluentes para que sejam mantidos os padrões de qualidade determinados.

- Resolução CNRH no 16/2001 de 08 de maio de 2001: estabelece critérios gerais para a outorga de direito de uso de recursos hídricos. Ela estabelece o princípio a ser considerado na análise dos pedidos, tratando-se da consideração da interdependência das águas superficiais e subterrâneas e suas interações observadas no ciclo hidrológico, visando à gestão integrada dos recursos hídricos. Essa Resolução estabelece os procedimentos para transferências do ato de outorga a terceiros, renovações de outorgas e emissão de outorgas preventivas. São determinados, ainda, prazos de vigência, prioridades e critérios para a determinação de usos insignificantes. Para as análises dos pedidos de outorga são determinados os itens mínimos a serem observados, como os Planos de Recursos Hídricos, as prioridades de uso estabelecidas, a classe de enquadramento do corpo d' água, as vazões mínimas a serem mantidas no rio, os usos múltiplos previstos e a manutenção das condições adequadas ao transporte aquaviário, quando couber. Especificamente no caso da outorga para lançamento de efluentes, é recomendado que a outorga seja concedida em função da análise da quantidade de água necessária para a diluição da carga poluente, com padrões de qualidade correspondentes à classe de enquadramento do corpo receptor e/ou em critérios específicos definidos no correspondente plano de recursos hídricos ou pelos órgãos competentes. A Resolução 16/2001 do CNRH é uma regulamentação dos procedimentos gerais de outorga a serem adotados pelas autoridades outorgantes no País.

- Resolução CNRH n 29/2002 de 11 de dezembro de 2002: estabelece diretrizes complementares para a outorga de empreendimentos relativos a uma determinada atividade setorial, sendo aquela referente ao aproveitamento de recursos minerais. Considerando que podem ser empreendimentos de grande porte, envolvendo recursos financeiros de grande volume e, na sua maioria, sem possibilidade de alteração da locação, observou-se a necessidade de discussão de uma Resolução específica para esse setor. 
- Resolução CNRH no 37/2004 de 26 de março de 2004: tem como finalidade o estabelecimento de diretrizes para outorga de recursos hídricos para implantação de barragens em corpos de água de domínio estadual, distrital ou da União.

O Conselho Nacional de Meio Ambiente - CONAMA apresenta algumas Resoluções relacionadas direta ou indiretamente com o instrumento de outorga da Política Nacional de Recursos Hídricos. Estas Resoluções são consideradas nos processos de análise de outorga e na integração com o licenciamento ambiental, instrumento da Política Nacional de Meio Ambiente, tais Resoluções são as seguintes:

- Resolução CONAMA no 237/97: tem como finalidade regulamentar os aspectos do licenciamento ambiental. Esta resolução relaciona-se com a outorga uma vez que em seu parágrafo $1^{\circ}$ do artigo 10 consta que "no procedimento de licenciamento ambiental deverá constar, obrigatoriamente, a certidão da Prefeitura Municipal, declarando que o local e o tipo de empreendimento ou atividade estão em conformidade com a legislação aplicável ao uso e ocupação do solo e, quando for o caso, a autorização para supressão de vegetação e a outorga para o uso da água, emitidas pelos órgãos competentes".

- Resoluções CONAMA no 279/2001, 284/2001, 289/2001 e 312/2002: tratam de disciplinar o licenciamento ambiental para empreendimentos elétricos com pequeno potencial de impacto ambiental, irrigação, assentamentos de reforma agrária e carcinicultura na zona costeira, respectivamente. Estas Resoluções exigem a apresentação do termo de outorga de direito de uso de recursos hídricos para liberação da licença ambiental.

- Resolução CONAMA no 357/05: Dispõe sobre a classificação dos corpos de água e diretrizes ambientais para o seu enquadramento, bem como estabelece as condições e padrões de lançamento de efluentes. Esta Resolução relaciona-se diretamente com a outorga de lançamento de efluentes, uma vez que na análise de um pedido de outorga, com essa finalidade, deve-se considerar o padrão de qualidade a ser mantido no corpo de água, função dos parâmetros para sua classe de enquadramento.

- Resolução CONAMA no 397/08: itera o inciso II do $\S 4^{\circ}$ e a Tabela $X$ do $\S 5^{\circ}$, ambos do art. 34 da Resolução do CONAMA n 357, de 2005. As alterações são basicamente em relação aos padrões de lançamento de efluentes. 


\subsubsection{Aspectos Institucionais da Outorga de Direito de Uso dos Recursos Hídricos}

As instituições relacionadas ao processo de emissão de outorga de direito de uso dos recursos hídricos apresentam suas competências previstas na Política Nacional de Recursos Hídricos (Lei 9433/97).

As entidades integrantes do Sistema Nacional de Gerenciamento de Recursos Hídricos - SNGERH relacionadas ao processo de outorga apresentam suas atividades e competências definidas através de instrumentos legais. Estas entidades são:

- Conselho Nacional de Recursos Hídricos - CNRH: suas competências são estabelecidas pelas Leis no 9.433/97 e no 9.984/2000 e pelo Decreto oㅜ 4.613, de 11 de março de 2003, e algumas delas se referem direta ou indiretamente à outorga. Uma de suas competências trata de deliberar sobre os projetos de aproveitamento de recursos hídricos cujas repercussões extrapolem o âmbito dos Estados em que serão implantados. Outra atribuição do $\mathrm{CNRH}$ é a de aprovar o Plano Nacional de Recursos Hídricos e determinar as providências necessárias ao cumprimento de suas metas. Uma vez que o Plano deverá conter as prioridades para outorga de direitos de uso de recursos hídricos, a sua aprovação pelo $\mathrm{CNRH}$ faz com que ele tenha relação direta com a emissão de outorga para os diversos setores de usuários. No entanto, a competência do CNRH mais diretamente relacionada com a outorga é a que trata de estabelecer critérios gerais para a outorga de direito de uso de recursos hídricos. Sendo assim, o $\mathrm{CNRH}$ tem discutido e estabelecido Resoluções acerca de temas afetos à outorga, com a finalidade de estabelecer seus critérios gerais.

- Agência Nacional de Águas: é o órgão do Poder Executivo Federal responsável pela implementação do SNGERH, tendo como atribuição disciplinar, em caráter normativo, a implementação, a operacionalização, o controle e a avaliação dos instrumentos da Política Nacional de Recursos Hídricos, dentre eles a outorga. A ANA é, ainda, o órgão gestor responsável pela outorga de direito, regulamentação e fiscalização dos usos de recursos hídricos em corpos de água de domínio da União, por meio de autorizações. 
- Conselhos de Recursos Hídricos dos Estados e do Distrito Federal: representam as autoridades outorgantes responsáveis pelos corpos de água de domínio Estadual e do Distrito Federal.

- Comitês de Bacia Hidrográfica: suas competências estão previstas na Legislação Federal no 9.433/97. Entre suas competências definidas na Lei estão a aprovação do Plano de Recursos Hídricos da Bacia e o acompanhamento de sua execução. No conteúdo dos planos de recursos hídricos está previsto o balanço entre as disponibilidades e demandas futuras dos recursos hídricos em quantidade e qualidade e a definição das prioridades para outorga. Esses estudos deverão, portanto, dar subsídios à emissão de outorgas na referida bacia. Outra competência estabelecida para os Comitês de Bacia é a de propor ao Conselho Nacional de Recursos Hídricos e aos Conselhos Estaduais critérios para a determinação de usos insignificantes da água no que se referem às acumulações, derivações, captações e lançamentos de efluentes;

- Órgãos dos poderes públicos federal, estaduais, municipais e do Distrito Federal cujas competências se relacionem com a gestão de recursos hídricos: As Agências de Águas têm dentre suas competências manter atualizado o balanço da disponibilidade de recursos hídricos em sua área. Para isso é necessária a manutenção de banco de dados com as outorgas concedidas pelas autoridades outorgantes competentes. Compete às agências propor, ao respectivo Comitê de Bacia, o enquadramento dos corpos de água, o qual será encaminhado ao Conselho Nacional ou Estadual de Recursos Hídricos para sua aprovação. Esse enquadramento é fundamental para a análise e emissão das outorgas, especialmente aquelas de lançamento de efluentes.

\subsection{Critérios de Outorga de RH}

Conforme apresentado no panorama da outorga no Brasil, observa-se um número significativo de outorgas já concedidas, no entanto, a outorga de direito de uso da água é um instrumento em fase de implementação e aprimoramento, pois ainda verificam-se algumas dificuldades na aplicação e, consequente, efetivação do instrumento. As dificuldades encontradas são metodológicas, onde se caracteriza a falta de critérios estabelecidos que considerem todos os aspectos envolvidos na tomada de decisão. Esta 
situação se agrava e torna-se mais evidente quando se avaliam bacias críticas com baixa disponibilidade hídrica e quando se deseja avaliar a outorga de efluentes.

Atualmente a maioria dos estados brasileiros avalia o processo de outorga através da análise de um balanço hídrico, onde a vazão máxima outorgável é igual a vazão de referência ou uma porcentagem desta no local da análise subtraído-se os valores já outorgados a montante. Nesta verificação é importante analisar se o novo valor outorgado para o local não prejudicará os balanços nas outorgas já concedidas para jusante. Esta prática, comum da maioria dos órgãos gestores, avalia apenas o impacto quantitativo e não considera o impacto qualitativo deste uso.

Ao introduzir a outorga de efluentes (vazão de diluição) aumenta-se o grau de complexidade envolvido na análise da outorga, onde devem ser consideradas a matriz de cargas poluidoras na bacia hidrográfica, a capacidade de assimilação e o processo de autodepuração do corpo receptor. Este tipo de análise confere ao processo maior dificuldade quando comparado ao balanço hídrico, exigindo maior conhecimento técnico específico. Desta forma, evidencia-se a necessidade do desenvolvimento de uma ferramenta que auxilie as análises de outorga, a qual considere integradamente os aspectos envolvidos no processo para a efetivação do instrumento de outorga.

$\mathrm{Na}$ continuidade desta tese são discutidos alguns desafios que devem ser avaliados para a integração dos aspectos de quantidade de qualidade. Estes desafios podem ser metodológicos ou técnicos sendo necessário avaliar desde a integração entre os órgãos envolvidos nas análises, os critérios adotados e a ferramentas que possibilitam avaliar todas as alternativas e estratégias propostas, visando o desenvolvimento sustentável da bacia hidrográfica e a harmonia entre os usos.

\subsubsection{Gestão integrada de recursos hídricos e ambiental}

A Lei 9.433/97 estabelece em suas diretrizes gerais para sua implementação a ação integrada entre seus instrumentos de gestão, assim como entre os instrumentos de recursos hídricos e ambiental. Esta integração é fundamental para a melhoria dos problemas de qualidade da água dos corpos hídricos e para a solução dos conflitos de uso.

Neste processo articulador, o instrumento enquadramento dos corpos hídricos possui papel fundamental para os demais instrumentos de gestão de recursos hídricos como a outorga, cobrança e planos de bacia, assim como, para os instrumentos de gestão ambiental, entre os quais destacam-se o licenciamento, monitoramento, termos de ajustamento de conduta e o controle da poluição. Estes instrumentos de gestão de recursos 
hídricos e ambiental devem adotar as metas intermediárias e/ou finas do enquadramento em seus procedimentos.

Desta forma, o enquadramento fornece diretrizes para o planejamento, fiscalização e monitoramento dos órgãos licenciadores, e para a formulação de critérios de penalidades, assim como para os instrumentos de gestão de recursos hídricos, como a outorga de lançamento de efluentes e a cobrança pelo uso dos recursos hídricos. O programa de efetivação do enquadramento dará diretrizes para os órgãos gestores de recursos hídricos e os órgãos ambientais competentes monitorar, controlar e fiscalizar as condições de qualidade da água do corpo hídrico, e assim, avaliar se as metas do enquadramento estão sendo cumpridas.

O enquadramento dos corpos d'água, como um instrumento que promove a integração de qualidade e quantidade de água, fortalece a articulação entre os instrumentos de gestão hídrica e ambiental, garantindo a disponibilidade de água nos padrões adequados para atender seus usos múltiplos. Uma vez incorporadas as metas do enquadramento nas análises de outorga, esta integração acarretará na efetivação dos objetivos da PNRH.

Neste contexto de integração entre os órgãos de recursos hídricos e ambiental merecem destaque os instrumentos de outorga e licenciamento, onde ambos visam o disciplinamento legal do uso do bem comum. A outorga visa assegurar o controle quantitativo e qualitativo dos usos da água e o efetivo exercício dos direitos de acesso à água, de modo que as condições previstas no licenciamento sejam efetivamente possíveis.

No entanto, segundo Porto (2009) um dos grandes desafios da integração da outorga e do licenciamento ambiental é a exigência de decisões e base de informação comum. Esta decisão não precisa de ser realizada pelo mesmo órgão, pois manter as diferentes visões enriquece e complementa a decisão, ou seja, as opiniões são complementares quando utilizam na análise os mesmo conceitos e diretrizes.

\subsubsection{Marco regulatório para concessão de outorgas}

A exemplo do que vem sendo implantado pela ANA, o marco regulatório foi criado tendo em vista fornecer critérios específicos para a concessão de outorga em função das especificidades locais de cada bacia hidrográfica. Este mecanismo é útil no estabelecimento de procedimentos administrativos e de critérios para avaliação dos pedidos de outorga, sendo materializado por meio de resoluções e de instrumentos de integração.

O marco regulatório pode ser entendido como um conjunto de regras para uso, controle, monitoramento e fiscalização de recursos hídricos, executadas pelas autoridades outorgantes, com base em diretrizes e prioridades de uso da água, de forma negociada 
entre os órgãos gestores de recursos hídricos, comitês de bacia, usuários de água e órgãos ambientais (ANA, 2010).

O acompanhamento do marco regulatório se dá por meio de reuniões com os usuários e comitês de bacia, verificação do cumprimento das regras estabelecidas, reuniões de planejamento dos usos e verificação da eventual entrada de novos usuários na bacia. As atualizações são necessárias, especialmente quando há previsão de implantação de nova infraestrutura hídrica relevante na bacia, aumento significativo de usuários ou outras situações que impliquem a necessidade de mudanças nas regras estabelecidas.

O marco regulatório propõe regras de uso através da uniformização dos consumos, assim como, estabelece regras básicas de restrições de usos conforme as possíveis alterações no regime hídrico (nível do rio).

O instrumento de outorga precisa de regras e estratégias claras e objetivas que considerem as especificidades locais, onde os usuários da bacia devem participar do processo decisório tendo em vista seu cumprimento e a efetivação da gestão de recursos hídricos.

\subsubsection{Disponibilidade hídrica, vazão de referência e vazão outorgável}

As análises de outorga de direito de usos d'água tem início na avaliação da disponibilidade hídrica do local onde se pretende implementar o empreendimento e seus impactos sobre outros empreendimentos a jusante. A disponibilidade hídrica deve ser avaliada tanto em quantidade como em qualidade d'água, pois é este conjunto que define a situação de escassez do recurso.

O entendimento do balanço hídrico é um dos fundamentos importantes para conhecer os efeitos antrópicos sobre o meio natural. O conhecimento da disponibilidade hídrica e da sustentabilidade ambiental depende de vários fatores como: precipitação, evapotranspiração potencial, condições do solo, uso do solo e geologia subterrânea, onde a bacia hidrográfica é o melhor espaço de avaliação do comportamento hídrico (Tucci, 2009).

Segundo Cruz (2001) a estimativa da disponibilidade reveste-se de particular interesse, pois dela depende a quantidade de água que poderá ser outorgada no sistema de recursos hídricos. A escolha da variável que caracteriza a disponibilidade constitui também uma questão não bem resolvida no processo evolutivo das novas questões relativas à proteção dos recursos hídricos. A caracterização da variabilidade, da sazonalidade e da aleatoriedade do comportamento hidrológico são informações que devem estar associadas à própria definição da disponibilidade hídrica, através de suas estatísticas e intervalos de confiança. 
Com o enfoque voltado para a outorga de efluentes de forma integrada, não se pode descartar da análise de disponibilidade hídrica o comprometimento qualitativo da vazão remanescente no corpo hídrico. Assim, a escolha da vazão de referência deve ser vista de uma forma abrangente, permitindo avaliar o impacto quantitativo, assim como, o balanço de qualidade de água e o perfil de qualidade ao longo do curso d’água.

A vazão de referência é um valor estipulado pelo órgão gestor com o intuito de que essa vazão garanta, com determinada segurança, a sustentabilidade da bacia hidrográfica ao longo do tempo. Segundo Art. $2^{\circ}$ da Resolução CON AMA n. ${ }^{\circ} 357 / 2005$, a vazão de referência do corpo hídrico é utilizada como base para o processo de gestão, tendo em vista o uso múltiplo das águas e a necessária articulação das instâncias do Sistema Nacional de Meio Ambiente - SISNAMA e do Sistema Nacional de Gerenciamento de Recursos Hídricos - SINGREH.

As vazões de referência são estipuladas pelos órgãos gestores baseadas, na maioria dos casos, em métodos estatísticos como a $Q_{7,10}$ (vazão mínima média de sete dias com período de retorno de 10 anos) e vazões de permanência como a $Q_{95 \%}$, o que lhes confere um grau ou risco de ocorrência.

Muitos estados brasileiros adotam uma fração destas vazões de referência como limite máximo outorgável (Vazão Máxima Outorgável), o que confere uma incerteza ao risco de ocorrência da variável estatística previamente determinada. A Tabela 3.1 apresenta os critérios adotados pelos órgãos gestores para outorga de captações superficiais.

Tabela 3.1- Critérios adotados para outorga de captação de águas superficiais.

\begin{tabular}{|c|c|c|c|c|}
\hline $\begin{array}{l}\text { Órgão } \\
\text { Gestor }\end{array}$ & $\begin{array}{l}\text { Vazão Máxima } \\
\text { Outorgável }\end{array}$ & $\begin{array}{c}\text { Legislação } \\
\text { Referente à Vazão } \\
\text { Máxima Outorgável }\end{array}$ & $\begin{array}{l}\text { Limites Máximos } \\
\text { de Vazões } \\
\text { Consideradas } \\
\text { Insignificantes }\end{array}$ & $\begin{array}{c}\text { Legislação } \\
\text { Referente à } \\
\text { Definição das } \\
\text { Vazões } \\
\text { Insignificantes }\end{array}$ \\
\hline ANA & $\begin{array}{l}70 \% \text { da Q95 podendo } \\
\text { variar em função das } \\
\text { peculiaridades de cada } \\
\text { região. } 20 \% \text { para cada } \\
\text { usuário individual. }\end{array}$ & $\begin{array}{l}\text { Não existe, em } \\
\text { função das } \\
\text { peculiaridades do } \\
\text { País, podendo variar } \\
\text { o critério. }\end{array}$ & $1,0 \mathrm{~L} / \mathrm{s}$ & $\begin{array}{c}\text { Resolução ANA } \\
542 / 2004\end{array}$ \\
\hline $\mathrm{SRH}-\mathrm{BA}$ & $\begin{array}{l}80 \% \text { da Q90 20\% para } \\
\text { cada usuário individual }\end{array}$ & $\begin{array}{c}\text { Decreto Estadual } \\
6.296 / 97\end{array}$ & $0,5 \mathrm{~L} / \mathrm{s}$ & $\begin{array}{c}\text { Decreto Estadual } \\
6.296 / 97\end{array}$ \\
\hline SRH-CE & $90 \%$ da Q90reg & $\begin{array}{c}\text { Decreto Estadual no } \\
23.067 / 94\end{array}$ & $\begin{array}{c}2,0 \mathrm{~m}^{3} / \mathrm{h}(0,56 \mathrm{~L} / \mathrm{s} \\
\text { - para águas } \\
\text { superficiais e } \\
\text { subterrâneas })\end{array}$ & $\begin{array}{l}\text { Decreto Estadual } \\
\text { no } 23.067 / 94\end{array}$ \\
\hline $\begin{array}{l}\text { SEMARH- } \\
\text { GO }\end{array}$ & 70\% da Q95 & $\begin{array}{l}\text { Não possui } \\
\text { legislação } \\
\text { específica. }\end{array}$ & $\begin{array}{l}\text { Não estão ainda } \\
\text { definidos }\end{array}$ & - \\
\hline
\end{tabular}




\begin{tabular}{|c|c|c|c|c|}
\hline $\begin{array}{l}\text { Órgão } \\
\text { Gestor }\end{array}$ & $\begin{array}{l}\text { Vazão Máxima } \\
\text { Outorgável }\end{array}$ & $\begin{array}{l}\text { Legislação } \\
\text { Referente à Vazão } \\
\text { Máxima Outorgável }\end{array}$ & $\begin{array}{l}\text { Limites Máximos } \\
\text { de Vazões } \\
\text { Consideradas } \\
\text { Insignificantes }\end{array}$ & $\begin{array}{c}\text { Legislação } \\
\text { Referente à } \\
\text { Definição das } \\
\text { Vazões } \\
\text { Insignificantes }\end{array}$ \\
\hline IGAM-MG & $\begin{array}{c}30 \% \text { da Q7,10 para } \\
\text { captações a fio d'água. } \\
\text { Para captações em } \\
\text { reservatórios, podem ser } \\
\text { liberadas vazões } \\
\text { superiores, mantendo o } \\
\text { mínimo residual de } 70 \% \\
\text { da Q7,10 durante todo o } \\
\text { tempo. }\end{array}$ & $\begin{array}{l}\text { Portarias do IGAM } \\
\text { no 010/98 e 007/99. }\end{array}$ & $\begin{array}{l}1,0 \mathrm{~L} / \mathrm{s} \text { para a } \\
\text { maior parte do } \\
\text { Estado e } 0,5 \mathrm{~L} / \mathrm{s} \\
\text { para as regiões de } \\
\text { escassez (águas } \\
\text { superficiais) } 10,0 \\
\text { m³/dia (águas } \\
\text { subterrâneas) }\end{array}$ & $\begin{array}{l}\text { Deliberação } \\
\text { CERH-MG no } \\
\text { 09/2004 }\end{array}$ \\
\hline AAGISA-PB & $\begin{array}{c}\text { 90\% da Q90reg. Em } \\
\text { lagos territoriais, o limite } \\
\text { outorgável é reduzido em } \\
1 / 3 .\end{array}$ & $\begin{array}{l}\text { Decreto Estadual } \\
19.260 / 1997\end{array}$ & $\begin{array}{l}2,0 \mathrm{~m}^{3} / \mathrm{h}(0,56 \mathrm{~L} / \mathrm{s} \\
\text { - para águas } \\
\text { superficiais e } \\
\text { subterrâneas })\end{array}$ & $\begin{array}{c}\text { Decreto Estadual } \\
19.260 / 1997\end{array}$ \\
\hline $\begin{array}{l}\text { SUDERHSA- } \\
\text { PR }\end{array}$ & $50 \%$ da Q95 & $\begin{array}{c}\text { Decreto Estadual } \\
4646 / 2001\end{array}$ & $1,0 \mathrm{~m}^{3} / \mathrm{h}(0,3 \mathrm{~L} / \mathrm{s})$ & - \\
\hline SECTMA-PE & $\begin{array}{l}\text { Depende do risco que o } \\
\text { requerente pode assumir. }\end{array}$ & $\begin{array}{l}\text { Não existe } \\
\text { legislação } \\
\text { específica. }\end{array}$ & $\begin{array}{c}0,5 \mathrm{l} / \mathrm{s} \text { ou } 43 \\
\mathrm{~m}^{3} / \mathrm{dia} \text { (águas } \\
\text { superfciais) } 5,0 \\
\mathrm{~m}^{3} / \mathrm{dia} \text { (águas } \\
\text { subterrâneas para } \\
\text { abastecimento } \\
\text { humano) }\end{array}$ & $\begin{array}{c}\text { Decreto Estadual } \\
20.423 / 98\end{array}$ \\
\hline SEMAR-PI & $\begin{array}{c}\text { 80\% da Q95 (Rios) e } \\
80 \% \text { da Q90reg (Açudes) }\end{array}$ & $\begin{array}{l}\text { Não existe } \\
\text { legislação } \\
\text { específica. }\end{array}$ & $\begin{array}{l}\text { Não estão ainda } \\
\text { definidos }\end{array}$ & - \\
\hline SERHID-RN & 90\% da Q90reg & $\begin{array}{c}\text { Decreto Estadual № } \\
13.283 / 97\end{array}$ & $1,0 \mathrm{~m}^{3} / \mathrm{h}(0,3 \mathrm{~L} / \mathrm{s})$ & $\begin{array}{c}\text { Decreto Estadual } \\
\text { № } 13.283 / 97\end{array}$ \\
\hline SEMA-RS & Não está definido & - & $\begin{array}{l}\text { Media mensal até } \\
2,0 \mathrm{~m}^{3} / \text { dia (águas } \\
\text { subterrâneas) }\end{array}$ & $\begin{array}{c}\text { Decreto Estadual } \\
42047 / 2002\end{array}$ \\
\hline DAEE-SP & $\begin{array}{c}50 \% \text { da Q7,10 por bacia. } \\
\text { Individualmente nunca } \\
\text { ultrapassar } 20 \% \text { da } \\
\text { Q7,10. }\end{array}$ & $\begin{array}{l}\text { Não existe } \\
\text { legislação } \\
\text { específica. }\end{array}$ & $\begin{array}{l}5,0 \text { m³/dia (águas } \\
\text { subterrâneas) }\end{array}$ & $\begin{array}{c}\text { Decreto Estadual } \\
32.955 / 91\end{array}$ \\
\hline $\begin{array}{l}\text { SEPLANTEC } \\
\text {-SE }\end{array}$ & $\begin{array}{c}100 \% \text { da Q90 30\% da } \\
\text { Q90 para cada usuário } \\
\text { individual }\end{array}$ & $\begin{array}{c}\text { Não existe } \\
\text { legislação específica }\end{array}$ & $\begin{array}{c}2,5 \mathrm{~m}^{3} / \mathrm{h}(0,69 \\
\mathrm{L} / \mathrm{s})\end{array}$ & $\begin{array}{c}\text { Resolução № } \\
\text { 01/2001 }\end{array}$ \\
\hline $\begin{array}{l}\text { NATURATIN } \\
\text { S-TO }\end{array}$ & $\begin{array}{l}\text { 75\% Q90 por bacia. } \\
\text { Individualmente o máximo } \\
\text { é 25\% da mesma Q90. } \\
\text { Para barragens de } \\
\text { regularização, } 75 \% \text { da } \\
\text { vazão de referência } \\
\text { adotada. }\end{array}$ & $\begin{array}{l}\text { Decreto estadual já } \\
\text { aprovado pela } \\
\text { Câmara de outorga } \\
\text { do Conselho } \\
\text { Estadual de } \\
\text { Recursos Hídricos. }\end{array}$ & $\begin{array}{l}0,25 \mathrm{~L} / \mathrm{s} \text { ou } 21,60 \\
\mathrm{~m}^{3} / \mathrm{dia} \text {. A minuta } \\
\text { de } \\
\text { regulamentação } \\
\text { aprovada deve } \\
\text { alterar para } 1,0 \mathrm{~L} / \mathrm{s} \\
\text { ou } 21,60 \mathrm{~m}^{3} / \mathrm{dia}\end{array}$ & $\begin{array}{c}\text { Portaria } \\
\text { NATURATINS no} \\
118 / 2002\end{array}$ \\
\hline
\end{tabular}

Fonte: ANA, 2007

Os valores de vazões de referência apresentados na Tabela 3.1 sofrem diversos questionamentos, pois à medida que as bacias tornam-se críticas, seja devido ao aumento do número de usuários ou à degradação do corpo hídrico valores restritivos não são bem 
vistos pelos usuários d'água. Pois, valores de vazão de referência mais rígidos tornam o processo de outorga mais restritivo, podendo até impossibilitar a concessão de novas outorgas. Assim sendo, o grande objetivo do sistema de gestão é encontrar um equilíbrio entre o uso dos recursos hídricos e a sustentabilidade ambiental.

Valores restritivos para as vazões outorgáveis como os adotados pelo IGAM-MG e DAEE-SP, $30 \%$ da $Q_{7,10}$ e $50 \%$ da $Q_{7,10}$ para captações a fio d'água, respectivamente, sofrem críticas devido à possível perda da representatividade estatística que estas frações da vazão mínima de sete dias com período de retorno de 10 anos representem. Mendes (2007) em estudo de postos fluviométricos da bacia do rio Turvo/SP mostrou que dependendo da distribuição probabilística empregada, as frações de $50 \%$ e $30 \%$ da $Q_{7,10}$, podem ter probabilidade nula de ocorrer. Assim, observa-se que os valores inicialmente adotados como limites máximos outorgáveis, que visava o ordenamento do uso da água e garante o equilíbrio e a sustentabilidade da bacia hidrográfica, quando muito restritivos não desempenham seu papel adequadamente, pois com a suspensão das outorgas diversos usuários ficam as margens dos processo de outorga não sendo quantificado seu real impacto na bacia.

Sugerir ou determinar outro valor de referência não é uma tarefa fácil, devido à inexistência de um valor ideal. Da mesma forma como o estudo de Mendes (2007) mostrou que valores de 30 e $50 \%$ da $Q_{7,10}$ são restritivos ao desenvolvimento econômico da bacia hidrográfica, a adoção de um valor liberal ou relaxado pode trazer prejuízos à bacia em períodos de escassez ou estiagem. Esta situação destaca a importância da consolidação do sistema de gestão, onde os usuários devem estar cientes e respeitarem as regras impostas para o sistema de concessão de outorga.

Ao considerar o uso de frações da $Q_{7,10}$, ou da $Q_{x \%}$ como sendo a vazão disponível para uso consuntivo, o remanescente destas vazões vem a ser o valor disponível para a diluição de efluentes e a conservação do ecossistema. Desta forma, é possível considerar para os exemplos de Minas Gerais e São Paulo que as vazões ecológicas são $70 \%$ da $Q_{7,10}$ e $50 \%$ da $Q_{7,10}$, respectivamente.

Mendes (2007) evidenciou que a atividade de gestão dos recursos hídricos necessita de indicadores de disponibilidade hídrica para outorga que sejam mais precisos e que não imponham limites excessivos, restringindo os usos do recurso hídrico desnecessariamente. Estes indicadores não devem estabelecer valores idênticos para bacias distintas.

Segundo Collischonn et al. (2005) a quantidade de água necessária para garantir a sustentabilidade ecológica de um corpo d'água é variável no tempo, e os critérios para definir a vazão remanescente devem contemplar as vazões mínimas, nas estiagens e em outros períodos do regime hidrológico. Portanto, atribuir um valor único de referência, fixado pela Lei como mostrado na Tabela 3.1, que imponha os limites máximos a serem 
outorgados, não resolve os problemas relacionados com a outorga de direito de uso d'água. Assim sendo, os critérios de outorga devem estar voltados para a gestão participativa, onde cada bacia hidrográfica pode adequar seus limites considerando a disponibilidade hídrica da bacia, usando de artifícios como a outorga sazonal.

A dificuldade na adoção de uma vazão de referência é um desafio a ser vencido, pois não existe um valor único que represente as garantias de preservação ambiental e que ao mesmo tempo permita o desenvolvimento econômico da bacia hidrográfica. As dúvidas existentes e os conflitos entre os diferentes pontos de vista na determinação da vazão de referência não deve desqualificar sua importância.

A vazão de referência hoje é indispensável para o processo de outorga. No entanto, observa-se a necessidade de uma análise mais detalhada das metodologias existentes para o processo de outorga, onde os valores de referência devem ser revistos e avaliados com a introdução das análises de outorga de efluentes, assim como deve-se verificar as vantagens e desvantagens de critérios como a outorga sazonal, adoção de um conjunto de valores de

referência e riscos de não atendimento. Estes critérios devem estar acompanhados de um sistema de gestão participativo, onde todos os usuários da bacia necessitam estar presentes nas negociações e conscientes do funcionamento do processo de outorga.

\subsubsection{Sazonalidade no processo de outorga}

A sazonalidade hídrica caracteriza-se pela variação periódica do regime hidrológico como resultado de fenômenos naturais. Esta variação pode ser um aspecto importante na definição da vazão outorgável, pois permite uma variação no valor outorgado ao longo do ano.

A vazão de referência adotada nos processos de outorga se caracteriza como sendo uma vazão mínima dentro da qual, em situações de escassez, os usos outorgados possam ser atendidos. Assim sendo, a adoção de uma vazão de referência anual pode ser restritiva para períodos chuvosos e os valores de vazão de referência poderiam ser flexíveis.

Desta forma, ao considerar a sazonalidade para concessão de outorga o órgão gestor deve analisar as outorgas em período seco e úmido, ou seja, devem ser analisadas as vazões mínimas características de cada período e não apenas uma única vazão de referência. Alguns estudos buscam provar que para determinadas regiões hidrográficas é conveniente considerar a variabilidade sazonal nas análises de outorga, onde os ganhos sócio-econômicos podem ser significativos para a região.

Euclydes et al. (2006) estudaram a região hidrográfica do Rio Grande no Estado de Minas Gerais utilizando o critério da outorga sazonal para outorga de captação a fio d'água. Os resultados mostraram que para a vazão de referência de $30 \%$ da $Q_{7,10}$, foi possível 
aumentar a vazão outorgada em até $61,80 \%$ na bacia hidrográfica do Baixo Rio Grande (de $35,60 \mathrm{~m}^{3} / \mathrm{s}$ no período seco para $57,60 \mathrm{~m}^{3} / \mathrm{s}$ no período chuvoso). Para as demais subbacias estudadas do rio Grande os resultados foram expressivos com um acréscimo na vazão de $52,40 \%$ (de $217,90 \mathrm{~m}^{3} / \mathrm{s}$ no período seco para $332,10 \mathrm{~m}^{3} / \mathrm{s}$ no período chuvoso). Os resultados mostraram que considerando a outorga sazonal o aumento na oferta hídrica no período chuvoso é de $6,60 \mathrm{~m}^{3} / \mathrm{s}$ na região do Baixo Rio Grande e $34,20 \mathrm{~m}^{3} / \mathrm{s}$ nas demais sub-bacias do rio Grande.

Desta forma, através da aplicação de medidas não estruturais, como a modificação do critério de outorga pelo órgão gestor, e considerando uma demanda média de uso consuntivo de 0,95 L/s/ha, será possível incorporar ao processo produtivo, no período chuvoso, aproximadamente 7.000 ha irrigados na região do Baixo Rio Grande e 36.000 ha irrigados nas demais sub-bacias do rio Grande, totalizando assim 43.000 ha irrigados (Euclydes et al., 2006).

Ao acompanhar os trabalhos realizados pelos órgãos gestores fica visível a preocupação dos mesmos ao analisar um processo de outorga que fuja da rotina e dos métodos atualmente utilizados de análise, os quais têm como base um valor máximo ourtogável para a bacia. As incertezas quanto à metodologia adotada para outorga sazonal é motivo de preocupação e discussão, pois ao conceder esta outorga se abre precedente para que outras outorgas desse tipo sejam solicitadas, agregando um grau maior de complexidade na análise.

Este tipo de outorga necessita da participação do órgão gestor, do comitê e dos usuários da bacia que são os principais interessados, pois sem a participação e conscientização dos envolvidos no processo este tipo de outorga torna-se difícil e complexo. A exemplo desta dificuldade foi observado o pedido de outorga negado a um usuário na bacia do rio Turvo, no Estado de São Paulo em 2009, onde este usuário pretendia ampliar sua captação no período em que o rio estivesse em sua condição de cheia, visando o armazenamento de água em reservatórios para utilização no período de seca. O pedido resultou discussões internas no órgão gestor sobre todas as implicações na concessão desta outorga. Os questionamentos foram em torno da postura do próprio órgão em função de: ampliar as outorgas existentes ou incentivar técnicas racionais do uso da água; qual método seria utilizado para o cálculo da disponibilidade hídrica desta outorga durante o período de cheia; ao se conceder esta outorga abriria precedentes para que outras outorgas deste tipo fossem solicitadas, o que tornaria mais complexo o estudo desta nova disponibilidade hídrica.

As inquietações do órgão gestor ao tratar de uma nova metodologia que modifique toda a estrutura existente para a análise das outorgas são compreensíveis e evidenciam a 
necessidade de discussões e aprofundamentos metodológicos em função do processo de análise.

Uma outorga sazonal simplificada pode ser obtida através da divisão do regime hidrológico em dois períodos, úmido e seco. Este tipo de outorga pode ser aplicado desde que regras e metodologias sejam adotadas, pois quando se deseja trabalhar com uma disponibilidade hídrica sazonal é necessário que as vazões de referência sejam estipuladas para os dois períodos.

A outorga sazonal permite, ainda, que se disponha melhor dos recursos hídricos entre os diversos usuários, possibilitando que uns usem a água nos momentos em que outros não estão usando, isto traduz a utilização otimizada do recurso. Outro fator que deve ser considerado neste processo é a instituição da cobrança pelo uso da água, isto estimulará o pedido de outorgas sazonais por parte dos próprios usuários da bacia, uma vez que outorgar o uso pelo seu valor máximo, de captação ou lançamento, durante todo o ano, na maioria dos casos, não exprime a realidade e nestas circunstâncias o usuário estará pagando pela água que não estará sendo usada efetivamente.

Esta situação evidencia a necessidade de integração dos instrumentos de gestão de recursos hídricos para efetivação dos objetivos da Política Nacional de Recursos Hídricos. Neste contexto, destaca-se igualmente a necessidade de implantação de instrumentos de fiscalização e monitoramento dos usuários do sistema, tendo em vista o cumprimento e aplicação dos conceitos estabelecidos no processo de outorga.

\subsubsection{Custos de tratamento de efluentes}

A geração de resíduos é uma consequência direta das atividades humanas e do desenvolvimento econômico, no entanto, a gestão dos resíduos é fundamental para a manutenção do equilíbrio da qualidade de vida da população e do meio ambiente. A análise ponderada entre a produção de resíduos e as práticas de controle da poluição é essencial para o desenvolvimento sustentável. Este é o foco principal quando se analisa o instrumento de outorga de lançamento de efluentes. A partir desta constatação, esta tese tem entre seus objetivos o desenvolvimento de um sistema de suporte a decisão para auxiliar a efetivação da outorga de lançamento de efluentes. O SSD busca otimizar a redução do aporte de carga poluente através da minimização dos custos de tratamento de efluentes, assim como a maximização dos usos, visando manter a classe de qualidade da água estabelecida para o corpos hídrico.

A carência de sistema de esgotamento sanitário é um dos principais problemas associados à qualidade dos recursos hídricos no cenário urbano. Isto pode ser observado 
nos dados apresentados pelo Sistema Nacional de Informações sobre Saneamento no seu Diagnóstico dos Serviços de Água e Esgoto - 2008, os quais indicam que os níveis de atendimento de coleta e tratamento de esgoto permanecem baixos, $43 \%$ e $34 \%$ respectivamente. Entre os anos de 2007 e 2008 foi apresentado um crescimento de 8,8\% nos serviços de tratamento de esgoto, o que indica que estão sendo feitos investimentos no setor. No entanto, segundo dado do Ministério das Cidades (2010) estima-se que sejam necessários $R \$ 105,4$ bilhões para a universalização do saneamento no Brasil até 2020.

Brites (2010) indicou que no cenário de controle da poluição ainda deve ser acrescido o problema da carga difusa, urbana e rural, e os déficits de tratamento de efluentes do setor industrial. Porém, os recursos financeiros disponíveis não são suficientes para que sejam adotadas medidas que revertam esta situação em curto prazo, o que justifica a necessidade de planejamento através de técnicas de otimização para o estabelecimento das medidas de controle de poluição e para a minimização dos custos de tratamento de efluentes.

A efetivação da gestão de recursos hídricos está diretamente relacionada com questões de viabilidade técnica, social e econômica, uma vez que estes aspectos podem interferir na obtenção da meta desejada, seja ela em função da quantidade e da qualidade dos recursos hídricos. Portanto, estes aspectos devem ser inseridos integradamente no processo decisório. Esta tese desenvolveu uma análise sobre os aspectos econômicos relacionados aos custos dos sistemas de tratamento de esgoto doméstico, industrial e agrícola voltados para a concessão da outorga de efluentes.

A outorga de lançamento de efluentes visa conceder o direito de uso, no entanto, alguns critérios devem ser estabelecidos para que não ocorra a inviabilização dos usos múltiplos. Com isso, foi inserido no SSD desenvolvido uma análise do nível de tratamento dos efluentes visando a manutenção da meta de qualidade da água estabelecida pelo enquadramento dos corpos hídricos.

A análise dos custos de implantação das medidas de tratamento de efluentes é fundamental no processo de outorga e para a sustentabilidade do sistema de gestão de recursos hídricos. Esta abordagem possibilita o estabelecimento de alternativas de tratamento viáveis financeiramente, tanto para os usuários do setor público como do setor privado.

Desta forma, ressalta-se a importância do custo na avaliação da factibilidade das medidas de despoluição, o qual deve ser introduzido na tomada de decisão. No entanto, faltam dados referentes aos custos das medidas de despoluição e os dados existentes são de difícil acesso público, o que muitas vezes restringe a inclusão dos mesmos nas análises dos processos dos instrumentos de gestão da qualidade da água.

Tendo em vista suprir esta carência de informações, Brites (2010) desenvolveu uma fonte de consulta para análise preliminar dos custos de investimentos em medidas de 
despoluição hídrica, servindo de referência para técnicos e órgãos gestores de recursos hídricos e meio ambiente, bem como valer-se dessa ferramenta para subsidiar a elaboração das propostas do instrumento de planejamento enquadramento dos corpos d'água estabelecido pela Lei 9.433 de 1997. No estudo foram apresentadas funções de custo de implantação de estações de tratamento de esgoto doméstico, assim como funções de custo para o tratamento da carga de poluição difusa.

A integração da variável custo de implantação das estações de tratamento de efluentes em um SSD voltado para o processo de outorga de efluentes, o qual utiliza o processo de otimização para a minimização dos custos, é uma inovação para a gestão de recursos hídricos e contribui eficientemente para a efetivação do instrumento de outorga, tendo em vista a sustentabilidade financeira e da qualidade da água do corpo receptor.

A presente tese produziu uma adaptação das funções de custo para implantação de estações de tratamento de esgoto apresentadas por Brites (2010) para serem introduzidas no SSD para outorga de efluentes, essa adaptação consiste na obtenção do custo em função da capacidade de tratamento da estação, em L/s. O SSD desenvolvido utiliza as técnicas de otimização para a minimização dos custos de tratamento dos efluentes gerados a partir das diversas finalidades de uso, entre os quais foram adotados os domésticos, industriais e agrícolas.

A partir dos tipos de tratamentos aplicados aos efluentes domésticos e industriais foram selecionadas algumas funções de custo para serem inseridas no SSD. A Figura 3.2 indica as funções de custo adaptadas, em função da capacidade de tratamento, para construção do sistema de tratamento primário e para o sistema de lagoa anaeróbia seguida de lagoa facultativa. 


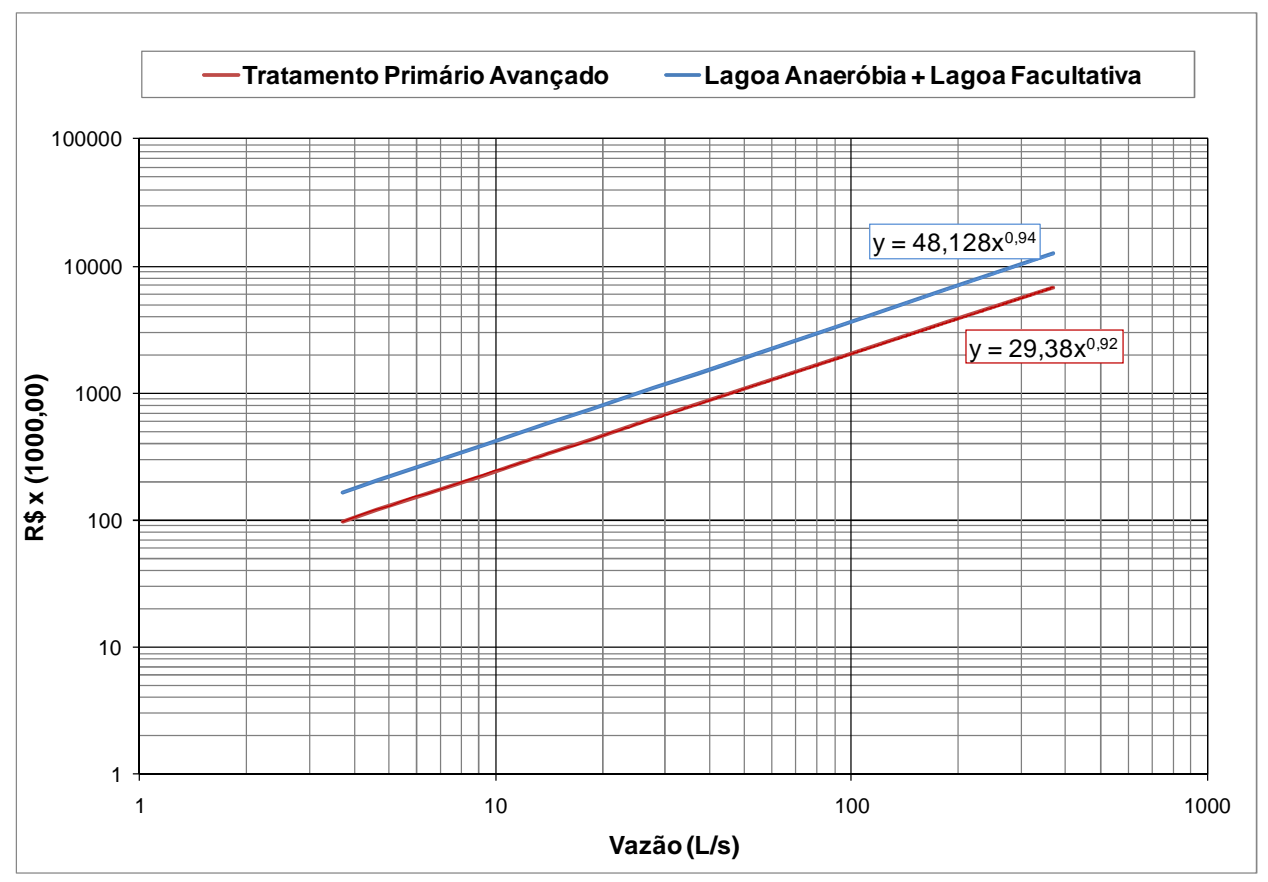

Figura 3.2 - Funções de custo para tratamento primário avançado e lagoas

A Figura 3.3 indica as funções de custo adaptadas de Brites (2010) para a implantação do reator UASB e para o sistema de UASB seguido de lodo ativado.

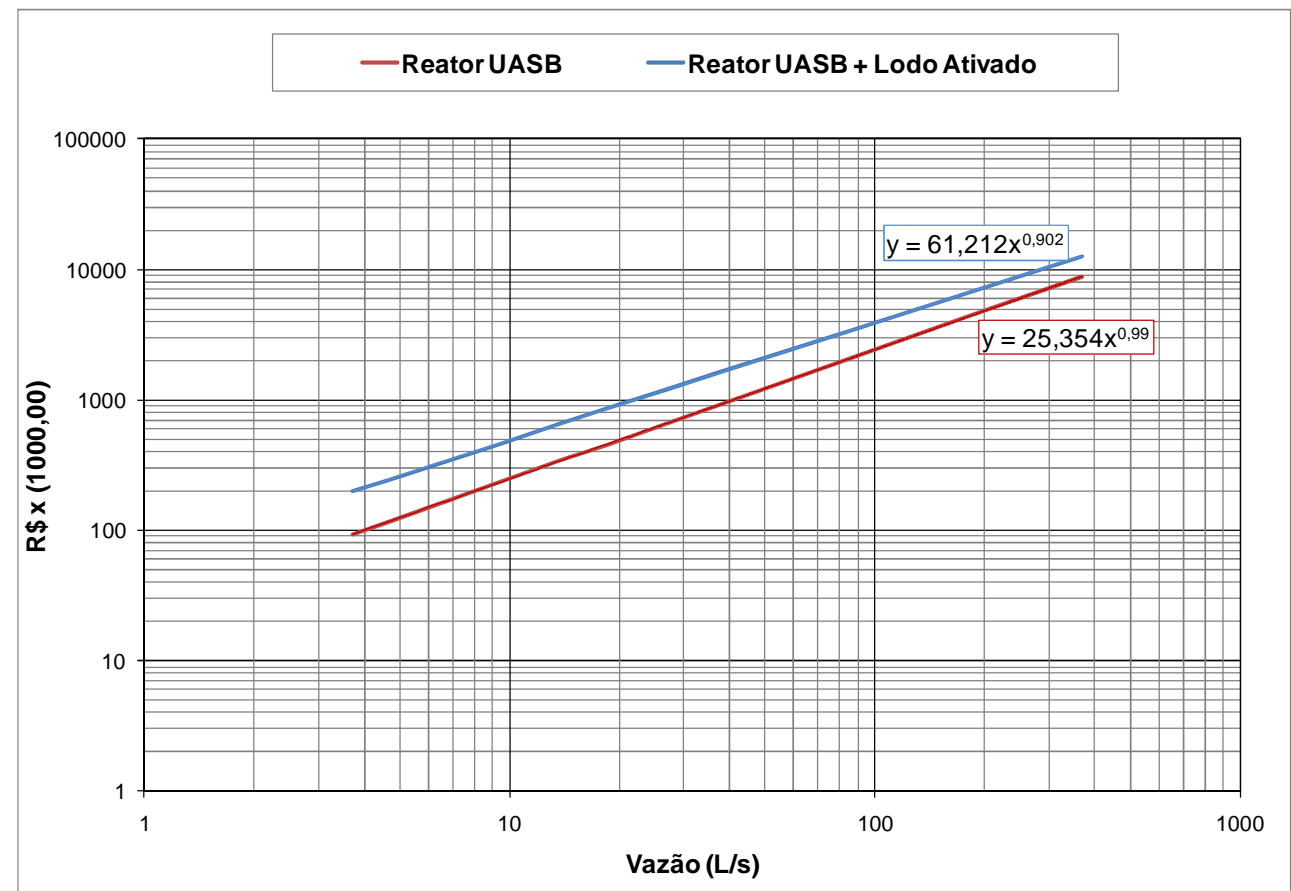

Figura 3.3 - Funções de custo para o sistema de reator UASB e para o sistema de UASB seguido de lodo ativado

As funções de custo para os sistemas de lodo ativado por aeração prolongada, lodo ativado seguido de filtração terciária e lodo ativado por batelada podem ser visualizadas na 
Figura 3.4, conforme adaptação das funções apresentadas por Brites (2010) para a capacidade de tratamento em L/s.

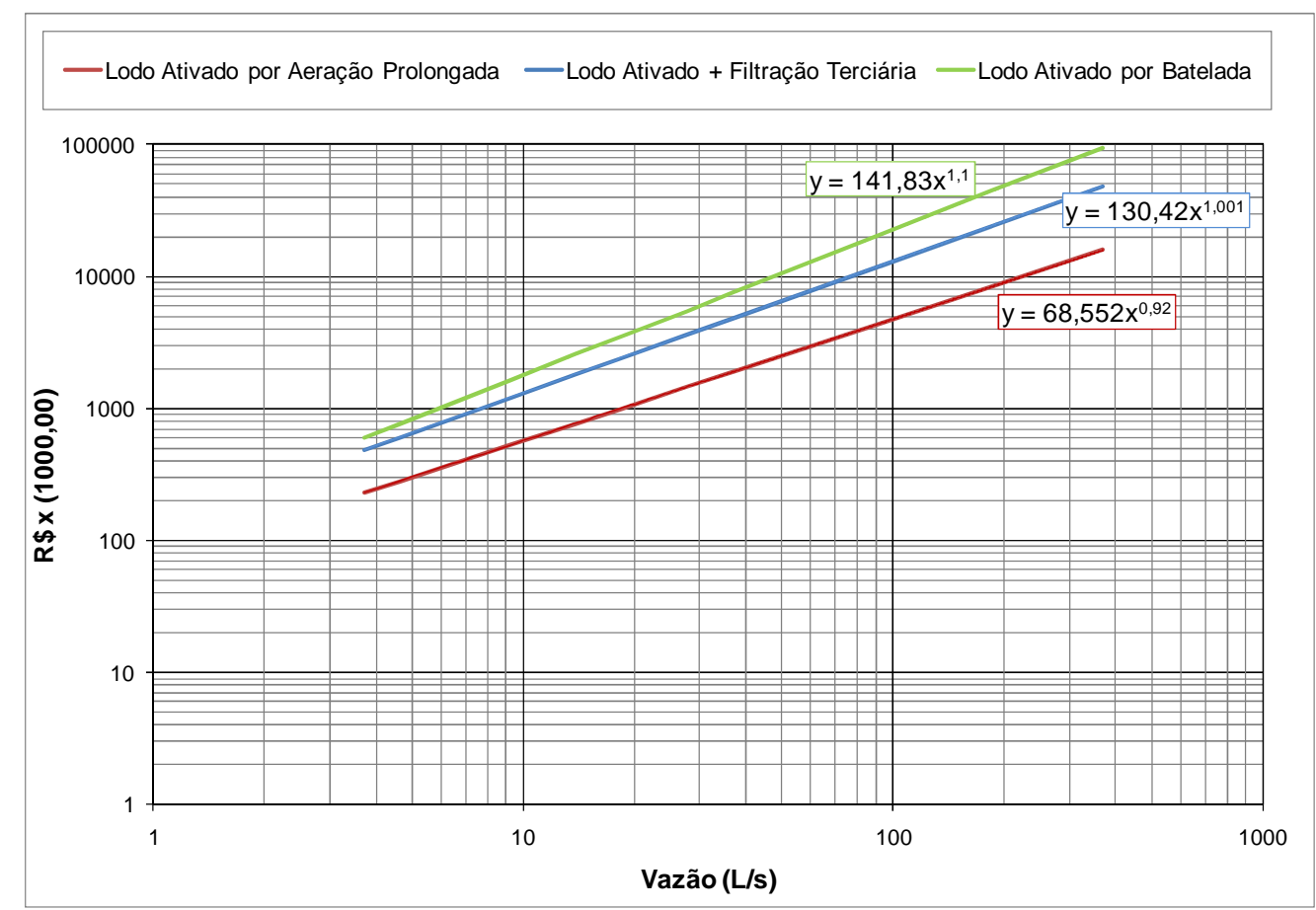

Figura 3.4 - Funções de custo para o sistema de lodo ativado seguido de pós-tratamento

O tratamento de efluentes agrícolas pode ser obtido através de um conjunto de medidas, as chamadas Melhores Práticas de Manejo (Best Management Practices BMP's), as quais são constituídas por medidas não-estruturais, visando a prevenção e o controle da emissão dos poluentes, e medidas estruturais, que visão a redução ou remoção dos poluentes do escoamento. A estimativa dos custos de implantação de medidas de tratamento de efluentes agrícolas foi realizada a partir das funções de custo apresentadas por Selvakumar (2004), o qual indicou uma série de funções para as medidas de controle de carga poluente através de bacia de detenção seca, bacia de retenção úmida, wetlands, trincheira de infiltração, bacia de infiltração, pavimento poroso, entre outras.

As funções de custo das BMP's estão relacionadas ao volume total de reservação para controle da poluição difusa. Para o caso do tratamento de efluentes agrícolas deve ser considerado o volume de retorno característico das áreas de irrigação. Os custos obtidos a partir das funções especificadas apresentam-se na moeda Americana (Dólar) e a data de cálculo foi em 2002. Assim sendo, os valores foram ajustados monetariamente considerando as informações cambiais do Banco Central do Brasil do dia 28 de julho de 2010 (U\$ $1=R \$$ $1,76)$. 
Tabela 3.2 - Custos medidas de controle de carga difusa.

\begin{tabular}{l|c|l}
\hline \multicolumn{1}{c}{ Tipo de Sistema } & Custo* da Medida (U\$) & \multicolumn{1}{c}{ Referência } \\
\hline Bacia de detenção seca & $\mathrm{C}=12,4^{*} \mathrm{~V}^{0, / 6}$ & Brown and Schueler, 1997 \\
Bacia de retenção úmida & $\mathrm{C}=24,5^{*} \mathrm{~V}^{0,11}$ & Brown and Schueler, 1997 \\
Wetlands & $\mathrm{C}=30,6^{*} \mathrm{~V}^{0,71}$ & U.S. EPA, 2003 \\
Trincheira de infiltração & $\mathrm{C}=5,0^{*} \mathrm{~V}$ & Brown and Schueler, 1997 \\
Bacia de infiltração & $\mathrm{C}=16,9^{*} \mathrm{~V}^{0,69}$ & Young et al., 1996 \\
Pavimento poroso & $\$ 2$ to $\$ 3 / \mathrm{ft}^{2}$ & U.S. EPA, 2003 \\
\hline
\end{tabular}

*Não foram incluídos custos de aquisição de área;

$\mathrm{V}=$ volume do escoamento destinado ao tratamento pela BMP $\left(\mathrm{ft}^{3}\right)$

Fonte: Selvakumar, 2004.

Quando se deseja obter estimativas de custo para implementação de obras, neste caso específico sistemas de tratamento de efluentes, ainda existe um logo caminho a ser percorrido no Brasil, devido à dificuldade de obtenção das informações para que as funções de custo possam ser aprimoradas e atualizadas. O SSD proposto permite estabelecer diferentes funções de custo para cada finalidade de uso, permitindo assim introduzir funções características do tipo de tratamento, assim como considerar as especificidades locais. As principais diferenças entre os custos de implementação dos sistemas de tratamento doméstico e industrial são em função das dimensões das estações, volumes tratados. Ainda deve ser considerado nesta diferenciação os diversos poluentes presentes nos efluentes industriais, os quais estão relacionados ao tipo de indústria. 


\section{OUTORGA DE LANÇAMENTO DE EFLUENTES}

A outorga qualitativa, na Lei 9.433/97, está disposta em termos de outorga para o lançamento de efluentes. No entanto, a Lei não especifica a consideração do processo de autodepuração do corpo d'água, para substâncias não conservativas, na análise da outorga. Esta consideração é feita na Resolução no 16/01 do Conselho Nacional de Recursos Hídricos (CNRH).

Em seu Artigo 12, a Resolução no 16 do CNRH estabelece: "A outorga deverá observar os planos de recursos hídricos e, em especial: I - as prioridades de uso estabelecidas; II - a classe em que o corpo de água estiver enquadrado, em consonância com a legislação ambiental; III - a preservação dos usos múltiplos previstos; e IV - a manutenção das condições adequadas ao transporte aquaviário, quando couber".

Em relação à disponibilidade dos volumes outorgados, o mesmo Artigo 12 da Resolução 16/01 determina que:

$\S 1^{\circ}$ As vazões e os volumes outorgados poderão ficar indisponíveis, total ou parcialmente, para outros usos no corpo de água, considerando o balanço hídrico e a capacidade de autodepuração para o caso de diluição de efluentes.

$\S 2^{\circ}$ A vazão de diluição poderá ser destinada a outros usos no corpo de água, desde que não agregue carga poluente adicional".

Quanto à diluição de efluentes, o Artigo 15 da Resolução no 16/01 estabelece que: "A outorga de direito de uso da água para o lançamento de efluentes será dada em quantidade de água necessária para a diluição da carga poluente, que pode variar ao longo do prazo de validade da outorga, com base nos padrões de qualidade da água correspondentes à classe de enquadramento do respectivo corpo receptor e/ou em critérios específicos definidos no correspondente plano de recursos hídricos ou pelos órgãos competentes".

A legislação sobre outorga de efluentes conduz o processo para uma gestão integrada entre os instrumentos de recursos hídricos. No Artigo 12, da Resolução 16/01 do $\mathrm{CNRH}$, pode-se dar destaque ao Item II, o qual estabelece que a outorga deve respeitar a classe em que o corpo d'água está enquadrado, assim como deve estar em consonância com a legislação ambiental.

O enquadramento dos corpos d'água é um instrumento de gestão que busca o atendimento dos padrões de qualidade relacionados com as classes de uso prioritários da bacia. Assim, o enquadramento dos corpos d'água visa garantir água em qualidade condizente com o uso à que esta se destina. Outra particularidade do instrumento de enquadramento é o estabelecimento de metas progressivas, ou seja, estabelece medidas de despoluição para atingir os objetivos de qualidade d'água propostos pelo enquadramento ao longo dos anos. 
A obtenção da meta final do enquadramento dos corpos d'água através de metas progressivas é um avanço significativo para o gerenciamento dos recursos hídricos, pois possibilita uma recuperação estratégica e progressiva diante da situação atual de crescente aumento da poluição dos rios.

Tendo em vista a integração dos instrumentos de gestão, as metas do enquadramento devem ser consideradas no processo de outorga. Logo, as outorgas de efluentes devem ser emitidas com prazos compatíveis com as metas progressivas estipuladas pelo enquadramento, onde a renovação da outorga deverá estar associada ao cumprimento das metas prevista para o período.

A outorga de efluentes tem o papel de controlar e disciplinar os usos através de medidas de gestão, as quais podem variar desde a imposição de limites outorgáveis ou através do incentivo ao uso racional da água, propondo medidas e incentivos para os usuários mais comprometidos com a sustentabilidade da bacia hidrográfica. Em condições mais críticas de qualidade do corpo receptor, seja por escassez ou por uso excessivo, este instrumento impõe a necessidade da adoção de medidas de despoluição para a liberação do uso. Logo, a outorga é um instrumento de comando e controle, tendo a função de orientar os usos em uma bacia e até mesmo, se for necessário, alterar o cenário de alocação de cargas através da renovação de outorgas. Esta alteração relaciona-se à avaliação dos limites máximos de captações e lançamento de efluentes e, até mesmo, a suspensão de uma outorga em condições mais críticas.

Avaliando-se a situação atual dos órgãos gestores observa-se que a outorga de qualidade da água ou outorga de lançamento de efluentes é um dos desafios a serem vencidos no sistema de gestão de recursos hídricos. Dentre as diversas dificuldades envolvidas nesta análise, pode-se dizer que uma das principais dificuldades do processo é o desconhecimento de como tratar o assunto e a falta de metodologia clara para auxiliar a decisão. A prática de concessão de outorga de direito do uso d'água, até pouco tempo atrás, tratava apenas de um balanço quantitativo, de montante para jusante, e não eram considerados os aspectos da qualidade da água no corpo hídrico, sendo que estes ficavam a cargo apenas do licenciamento ambiental.

A Figura 4.1 indica a distribuição das vazões outorgadas por finalidade de uso até o ano de 2007 (ANA, 2009). Os três usos principais, sendo eles irrigação, abastecimento público e consumo industrial, correspondem à, aproximadamente, $90 \%$ do total de outorga emitidas no país. Estes números mostram que o foco da emissão de outorgas até o momento voltava-se para usos quantitativos. 


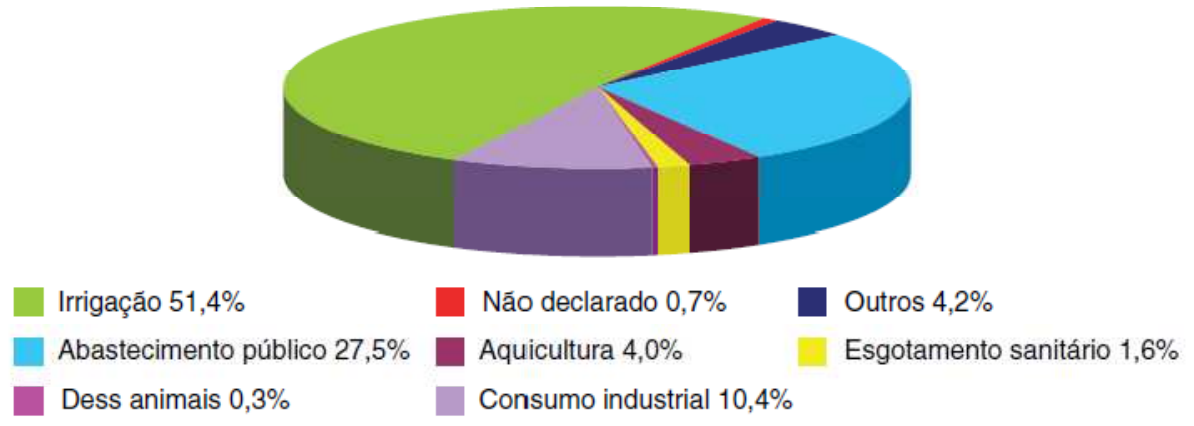

Figura 4.1 - Distribuição das vazões outorgadas no Brasil quanto aos usos (ANA, 2009).

Quando a outorga de efluente não é avaliada os lançamentos de efluentes são analisados apenas pelo órgão ambiental, onde o controle é realizado com base apenas no padrão de emissão, totalmente desvinculados do processo de emissão de outorga. Ao avaliar apenas os padrões de emissão, restringe-se a análise em uma questão pontual, onde na realidade deveriam estar sendo analisados todos os lançamentos de forma conjunta, ou seja, a bacia hidrográfica de maneira integrada. Desta forma, as medidas de controle de poluição podem ser otimizadas, o que pode conferir maior eficiência econômica na análise, em termos de remoção de carga e sem desprezar o controle ambiental.

A análise integrada dos aspectos quantitativos e qualitativos, necessários para a outorga de lançamento de efluentes ou outorga de diluição, é um dos grandes desafios a serem vencidos pelos órgãos gestores. Nesta linha, Cardoso da Silva \& Monteiro (2004) argumentaram que na outorga de lançamento de efluentes, os órgãos gestores de meio ambiente e de recursos hídricos deverão trabalhar de forma plenamente articulada. Esta articulação se deve à interdependência dos órgãos para a tomada de decisão, tendo em vista que as eficiências de tratamento de efluentes são definidas para a licença de instalação ambiental e as correspondentes cargas poluidoras remanescentes deverão estar em perfeita consonância com as vazões que poderão ser alocadas para a diluição desses poluentes, e vice-versa.

Isto reforça a afirmação de Porto (2009) ao enfatizar que a integração da outorga e do licenciamento ambiental exige decisões e base de informações comuns.

O processo de análise de outorga de lançamento de efluentes vem ganhando força nos últimos anos em função de sua previsão na Política Nacional de Recursos Hídricos, criada a mais de dez anos. Outro fator que contribui para os avanços observados no processo de outorga de efluentes é a pressão da sociedade, da legislação ambiental e dos próprios usuários do sistema pela manutenção dos padrões de qualidade previstos pelo enquadramento dos corpos d'água. 
A outorga para o lançamento de efluentes está disposta em função de uma vazão de diluição, a qual representa a quantidade de água que deve ser mantida no rio para diluir o efluente. No entanto, o que se observa é que na maioria dos corpos hídricos esta vazão não é disponibilizada em quantidade suficiente para diluir o efluente. Portanto, para estas situações as análises não devem ficar restritas sobre as vazões de diluição, sendo necessária a implantação de medidas que visem o controle e a redução da carga poluente afluente ao corpo receptor.

A análise de concessão de outorga de lançamento de efluentes é um processo complexo devido à quantidade de fatores que devem ser avaliados, entre os quais destacam-se a capacidade de assimilação do corpo receptor, a capacidade de auto depuração do corpo receptor, os níveis de tratamento que podem ser aplicados para o uso pretendido, a isonomia entre os usuários da bacia, a regra de prioridade entre os usuários, e o atendimento as metas de despoluição propostas pelo enquadramento dos corpos d'água. Apesar da complexidade da análise integrada, esta contribui para a sustentabilidade dos recursos naturais da bacia hidrográfica, promovendo a harmonia entre seus usuários.

Esta tese busca um aprofundamento na discussão da outorga de lançamento de efluentes. Assim sendo, o SSD proposto possui um importante papel na análise da outorga de efluentes, pois avalia de forma integrada as respostas para as diferentes estratégias de outorga propostas através da inserção de critérios que avaliam as vazões de diluição e propõe medidas de remoção de carga poluente. O conjunto de informações e respostas produzidos pelo SSD desenvolvido para as mais diversas análises é a principal contribuição deste estudo para que o órgão gestor possa discutir os diferentes critérios do processo de outorga de efluentes.

A discussão dos critérios adotados para a concessão de outorga deve buscar atender e avaliar, da melhor forma possível, as principais exigências dos usuários, dos órgãos ambientais e de recursos hídricos, onde devem ser incluídos aspectos técnicos e econômicos para a aplicação do instrumento de outorga.

No item a seguir serão discutidos alguns problemas que dificultam 0 desenvolvimento de um sistema para a análise integrada de outorga de efluentes.

\subsection{Análise dos problemas e variáveis envolvidas no processo de outorga de efluentes}

A prática brasileira no gerenciamento dos recursos hídricos mostra que apesar dos avanços já obtidos ainda existem algumas dificuldades a serem superadas entre a implantação dos instrumentos de gestão e seu adequado funcionamento sobre o ponto de vista técnico. 
A implementação do instrumento de outorga do direito de uso d'água, principalmente quando analisada a outorga para lançamento de efluentes, é complexa devido ao grande número de fatores envolvidos, esta situação se agrava quando analisadas bacias com escassez hídrica. Observa-se por parte dos órgãos gestores uma resistência em alterar ou reavaliar as variáveis ambientais e hidrológicas utilizadas atualmente e que se mostraram ineficientes ou desatualizadas. Esta resistência se deve as incertezas envolvidas no processo, aliada a inexistência de sistemas ou modelos que permitam analisar inúmeras estratégias de forma otimizada e que produzam uma análise mais robusta das alternativas possíveis de serem adotadas.

Um aspecto notório que limita a gestão de recursos hídricos, e não apenas no que tange a aplicação do instrumento de outorga de direito de uso, é a carência de dados de monitoramento de quantidade e qualidade da água, os quais devem compor o sistema de informação de recursos hídricos.

As estações de monitoramento existentes não cobrem todas as bacias hidrográficas, ocorrendo que grandes extensões de rios permanecem sem informações. Outro aspecto que deve ser observado, mesmo em regiões com maior número de estações de monitoramento, é que muitas vezes as informações de qualidade e quantidade não estão associadas. Isto permite analisar apenas a concentração do parâmetro e não traduz a situação do corpo hídrico, pois desta forma não é possível obter a carga de poluição existente no mesmo. A consolidação de redes de monitoramento é fundamental para consistência das informações de qualidade e quantidade da água, da mesma forma que sustenta a utilização de técnicas como a modelagem matemática essencial para a priorização de programas e ações para o controle da poluição. Portanto, o monitoramento integrado é imprescindível para a adequada gestão de recursos hídricos.

Outro problema comum que dificulta a análise de outorga é a falta de um cadastro de usuários d'água, com informações precisas e relevantes para o processo decisório. A maioria dos cadastros existentes são incompletos, não apresentando informações relevantes como o valor da vazão captada, a porcentagem de retorno e a concentração dos efluentes, assim como, não apresentam informações sobre a existência de tratamento para outorgas concedidas e sobre a eficiência de remoção de carga poluente. Todas estas informações são essenciais para a formulação das estratégias de outorga.

Destaca-se a importância de obter informações sobre as finalidades de uso para o estabelecimento de estratégias de outorga e para avaliar a isonomia entre os usuários, assim como a identificação da periodicidade do uso, o que possibilita avaliar critérios de outorga considerando a sazonalidade. 
O conjunto das infomações, citadas neste item, são relevantes para o processo decisório das análises de outorga de uso e devem estar presentes no cadastro de usuários, o qual contribui para a obtenção de um banco de dados consolidado.

A consolidação do sistema de informações, com base no monitoramento integrado de quantidade e qualidade da água e nas informações dos órgãos outorgantes, contribui significativamente para o processo de gestão, pois fundamenta a decisão sobre aspectos observados na bacia hidrográfica.

A outorga de direito de uso da d'água deve ser vista como um instrumento de gestão que visa orientar o uso com base no desenvolvimento sustentável, preservando as condições de vida do meio ambiente, assim como as necessidades dos usuários e, consequentemente, o desenvolvimento econômico da região.

O desenvolvimento econômico é outro aspecto que requer devida atenção, uma vez que resulta no aumento das demandas de água. Em bacias hidrográficas localizadas em regiões com baixa disponibilidade hídrica, seja em função de seus aspectos de quantidade ou qualidade, este processo de desenvolvimento pode torná-la crítica.

Uma bacia é considerada crítica através da análise de suas variáveis ambientais e hidrológicas, as quais apresentam limites para o uso da água de seu corpo hídrico. Estas variáveis podem restringir o desenvolvimento econômico de uma bacia ou região, pois estabelecem os limites para a concessão de outorgas.

A determinação dos valores e limites para as variáveis hidrológicas e ambientais pode ser considerada como uma das principais dificuldades técnicas nas análises da outorga de recursos hídricos. Estas variáveis representam a base deste instrumento de gestão, pois estipulam os limites de uso dos recursos hídricos.

As variáveis hidrológicas restritivas podem restringir o desenvolvimento sócioeconômico de uma região, mas por outro lado impedem o uso extremo do recurso o qual pode causar o colapso do sistema em épocas de escassez hídrica. Algumas variáveis hidrológicas, como a vazão de referência, são consideradas por muitos técnicos como parâmetros inalteráveis, no entanto, em muitos casos esses valores necessitam serem revistos.

A avaliação das variáveis ambientais sofre com o problema de interpretação, sendo em alguns casos realizada apenas uma verificação de obediência desta variável às exigências ambientais, o que não é suficiente para a gestão de recursos hídricos. Segundo Porto (2002) a necessidade da gestão de qualidade da água nasce do reconhecimento de que as atividades humanas produzem resíduos e esta é uma constatação inequívoca. É impossível ter a humanidade morando em aglomerados urbanos, produzindo alimentos e bens de consumo, expandindo seu desenvolvimento tecnológico, sem que haja aumento da produção de resíduos e, principalmente, sem que boa parte desses resíduos chegue aos 
corpos de água. Neste contexto que o instrumento de outorga de uso da água ganha destaque, ao propiciar o disciplinamento do uso com base nas exigências ambientais e no desenvolvimento sustentável.

O sistema decisório em recursos hídricos é um processo bastante complexo, para o qual não existem soluções fáceis quando os conflitos são declarados. Em virtude disto, os Sistemas de Suporte a Decisão ganham importância na análise decisória, pois os SSDs permitem analisar inúmeras alternativas de forma rápida e confiável, fornecendo informações para que as melhores alternativas sejam escolhidas minimizando as incertezas existentes no processo de gestão.

Outro aspecto que merece destaque é a adoção do valor da vazão de referência. Este parâmetro dificulta a concessão de outorga, principalmente em bacias críticas, devido aos valores restritivos adotados e a resistência dos órgãos gestores em avaliar valores menos restritivos. Valores de referência como, a $Q_{7,10}$ (vazão mínima com sete dias de duração e período de retorno de 10 anos) e a $Q_{x \%}$ (vazão associada à permanência de $x \%$ no tempo) são adotados para determinar os limites máximos outorgáveis. Muitos órgãos gestores adotam frações destes valores para determinar os limites máximos outorgáveis. Esta atitude atribui maior incerteza ao processo decisório, uma vez que se perde 0 significado estatístico. As vazões de referência baseadas nos critérios de permanência mostram-se mais adequadas para a gestão, pois permite tanto ao gestor como ao usuário do sistema avaliar de forma mais clara os riscos associados.

Ao se tratar da outorga de efluentes devem ser avaliados os aspectos ambientais, técnicos e econômicos no processo decisório. Esta análise integrada torna o processo mais complexo que a outorga apenas quantitativa, uma vez que além dos conceitos hidrológicos devem ser discutidas estratégias o estabelecimento de medidas de despoluição, tendo em vista o menor impacto econômico e ambiental na bacia hidrográfica. Valores muito restritivos de vazão de referência nas análises de outorga de lançamento de efluentes inviabilizam economicamente as medidas de despoluição, devido à necessidade de remoção de maior parcela de carga poluente.

A outorga de efluentes tem como objetivo analisar a matriz de poluição e o perfil de qualidade d'água do corpo hídrico. Para que uma outorga de efluente seja concedida é necessário que exista no corpo receptor uma vazão capaz de diluir o efluente a níveis aceitáveis de qualidade da água, sendo que esses valores determinados pela classe de enquadramento. $O$ volume de diluição para um efluente sem tratamento é muito elevado, desta forma, torna-se necessário o tratamento destes efluentes antes do seu despejo.

A legislação ambiental estipula os níveis máximos de carga ou eficiência mínima que os efluentes devem atender, mas o processo de gestão de uma bacia não deve ser visto apenas como uma verificação dos limites máximos estipulados pela legislação. No processo 
de gestão devem ser realizados estudos aprofundados para identificação dos pontos críticos de poluição e suas causas, para isso deve ser avaliado o comportamento conjunto de toda a matriz de poluição e seu impacto no perfil de qualidade ao longo do corpo receptor. Este tipo de análise permite avaliar quais os trechos de rio são considerados mais críticos e quais não respeitam os limites estipulados pelo enquadramento.

A análise do comportamento dos poluentes no corpo receptor é fundamental para o processo de outorga. Neste contexto, destaca-se um dos grandes avanços da Resolução CONAMA 357/05 ao considerar o processo de autodepuração do corpo hídrico nas análises do processo de gestão.

O processo de autodepuração está associado à capacidade de assimilação da carga poluente pelo do corpo hídrico, o que justifica a necessidade de monitoramento integrado de quantidade e qualidade, uma vez que a quantidade de vazão disponível influencia na capacidade de diluição do poluente. O processo ocorre na seguinte forma, os despejos causam uma degradação que se propaga ao longo do rio até que este tenha capacidade de assimilar da carga poluidora. Desta forma, se as substâncias lançadas não forem conservativas o processo de autodepuração contribuirá para o aumento das disponibilidades outorgáveis.

Um despejo, com vazão $Q_{\text {desp }}$ e concentração de determinado poluente $C_{\text {desp }}$, ao ser lançado no rio exige uma vazão de diluição $Q_{\text {dil }}$ para que a concentração limite $C_{\text {lim }}$ da classe de enquadramento não seja excedida. Esta vazão de diluição deve ficar indisponível para outros usos, o que reduz a capacidade de assimilação do curso de água para diluir outros despejos, assim como, pode reduzir também a disponibilidade para atendimento de outras outorgas quantitativas. Se o poluente for conservativo o comprometimento se estende por todo o rio e a capacidade de concessão de novas outorgas (quantidade e qualidade) somente aumenta com o aumento das vazões de contribuição ao longo do curso de água.

A Figura 4.2 ilustra o lançamento de um despejo, contendo uma substância não conservativa. Observa-se, no gráfico dos parâmetros OD e DBO, a alteração da qualidade da água em função do lançamento do efluente e a recuperação das condições iniciais de qualidade à medida que a carga é assimilada pelo corpo hídrico. Na Figura, é possível visualizar o volume de diluição necessário para manter a classe de enquadramento na seção de lançamento, da mesma forma, pode ser observado que o volume é gradativamente reduzido para jusante em função da capacidade de autodepuração dor corpo hídrico. O volume anteriormente utilizado para a diluição vai sendo disponibilizado para novas outorgas. 


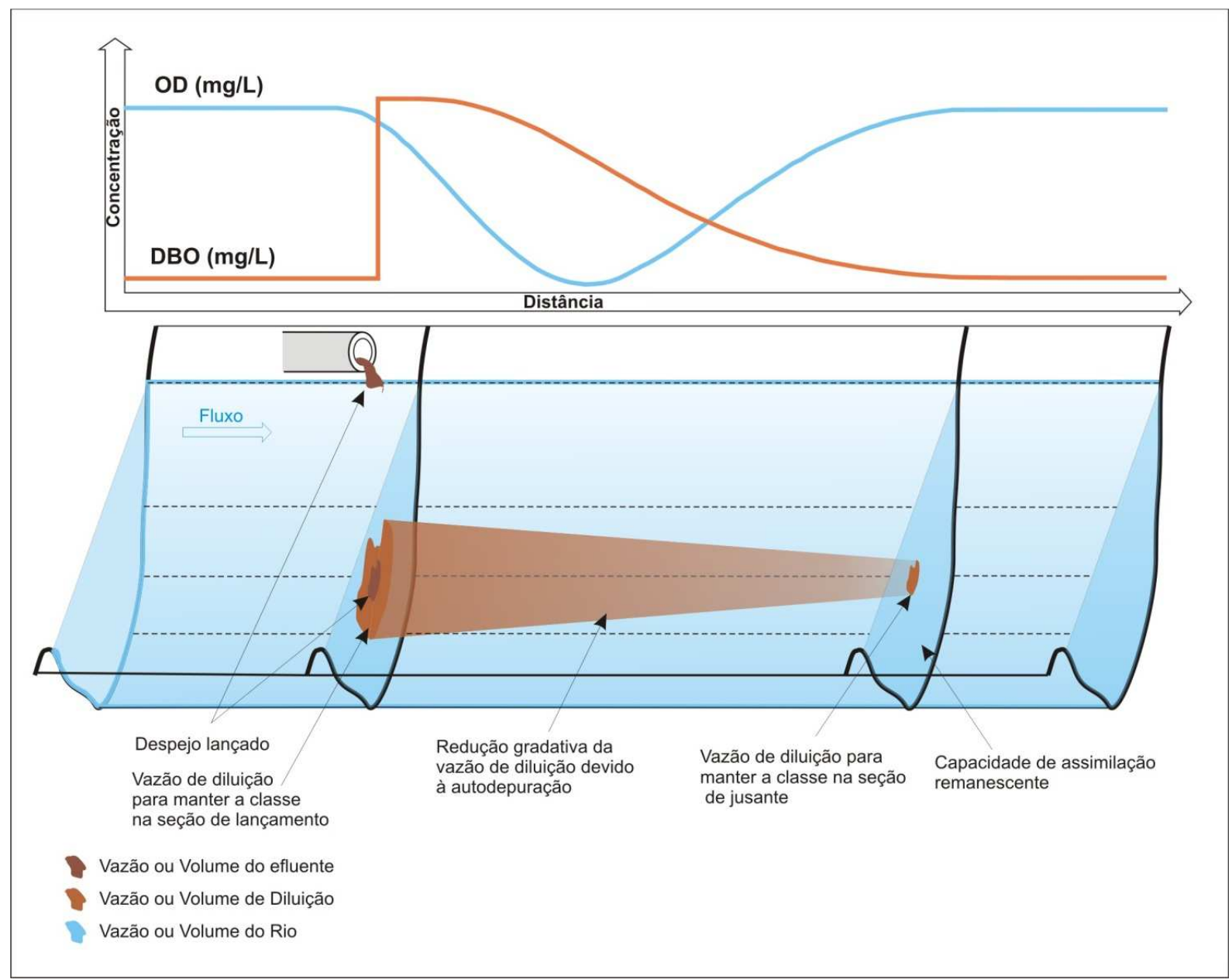

Figura 4.2 - Lançamento de efluente na seção do rio

Os lançamentos de efluentes de montante podem prejudicar os usuários de jusante, exigindo destes níveis de tratamento mais avançados e, consequentemente, maior custo de implantação e operação das estações de tratamento. Esta interdependência entre os despejos em um curso d'água torna o processo decisório ainda mais complexo, quando se busca que um usuário não tenha seu custo de produção onerado devido sua localização na bacia hidrográfica.

Como pode ser observado, o processo de outorga de efluentes não se limita apenas na avaliação do limite de carga do efluente, devendo incluir na análise o perfil de qualidade do rio, assim como, os custos e as alternativas de despoluição que devem se empregadas na bacia hidrográfica.

Uma das alternativas para reduzir os custos de tratamento de efluentes é através de técnicas de otimização, buscando-se reduzir os custos de implantação e operação das estações de tratamento de formal global na bacia hidrográfica em questão, sem considerar a isonomia entre os usuários do sistema.

Isonomia é um princípio jurídico disposto pela Constituição da República Federativa do Brasil que diz que "todos são iguais perante a lei", independentemente da riqueza ou 
prestígio. Logo, ao se considerar a isonomia entre os usos não se permite que um usuário tenha um custo de produção maior, devido à técnica de tratamento de efluente, que outro com a mesma finalidade de uso. Por outro lado, pode-se em alguns casos elevar o custo global das medidas de despoluição ao não considerar a variável ambiental. Neste caso a disponibilidade hídrica para diluição de efluentes, ganha caráter secundário na análise e as medidas de despoluição buscam a equidade de técnicas de tratamento para usos afins. Esta visão torna-se antieconômica e onera os usos da bacia aplicando medidas de despoluição que superam as estipuladas pelo enquadramento e órgãos ambientais.

Ao se avaliar o sistema com o objetivo único de obedecer aos limites de qualidade estipulados pelo enquadramento, os usuários localizados em regiões onde a variável ambiental é mais favorável são beneficiados, pois com maior disponibilidade para diluição de efluentes os custos e as remoções de carga são menores. Este tipo de metodologia pode causar uma concentração de usuários em regiões com maior disponibilidade ambiental, como ocorrido nas margens do Rio Mississippi nos Estados Unidos.

As licenças para os despejos na bacia do Rio Mississippi (EUA) eram baseadas na capacidade de assimilação do corpo receptor. A grande capacidade deste rio atraiu a instalação do setor industrial para a região, onde os custos com as medidas de despoluição eram significativamente menores que em outras regiões, com rios de menor capacidade assimilativa para os despejos. O aumento de usuários na bacia do Rio Mississippi provocou a degradação do corpo d'água com uma redução da qualidade ambiental no rio. A experiência ocorrida no rio Mississippi mostra que quando se avalia apenas a capacidade assimilativa do corpo d'água deve-se ter cuidado para que este não seja utilizado até seu limite, o que pode trazer prejuízos ambientais.

A isonomia entre os usuários de recursos hídricos é vista por muitos gestores como uma medida justa para distribuição dos custos de despoluição. Porém, este tipo de decisão pode onerar os usuários da bacia, pois desconsidera a variabilidade ambiental da bacia hidrográfica. No entanto, se apenas a variabilidade ambiental for utilizada na análise decisória pode haver uma concentração das principais atividades que causam a degradação do recurso hídrico em regiões mais favoráveis ambientalmente, como o ocorrido na bacia do Rio Mississippi.

Outra questão que deve ser a incluída na análise são os custos de implantação e operação dos sistemas de tratamento. Segundo Porto (2002), os custos financeiros a serem enfrentados num programa amplo de recuperação e conservação da qualidade das águas para o país são muito significativos, os quais são dependentes dos objetivos de qualidade que se deseja alcançar. Objetivos de qualidade muito restritivos têm o potencial de alcançar patamares ótimos de controle ambiental, mas seus custos podem ser exorbitantes. Objetivos muito modestos podem tornar irreversíveis determinadas situações de 
degradação, ameaçando a disponibilidade hídrica e concretizando a situação hipercrítica de escassez em algumas bacias hidrográficas.

Isso indica a conveniência da adoção de critérios otimizados para o escalonamento das ações que não fiquem restritos à imposições como a isonomia entre os usos, o que pode estipular níveis de tratamento elevados para trechos de rio que apresentam boas condições de qualidade da água. A otimização do sistema tem como objetivo a redução dos custos globais, permitindo a aplicação dos investimentos em áreas com maiores problemas de degradação. A necessidade desta análise otimizada para o processo de outorga é evidente e tornou-se a principal contribuição do SSD desenvolvido nesta tese.

O instrumento de outorga de direito de uso está em contínuo processo de amadurecimento de seus conceitos, e como visto neste Item a aplicação deste instrumento ainda é difícil dada a complexidade e fragilidade dos critérios envolvidos na análise, sendo estes fatores os principais motivadores para o desenvolvimento desta tese.

Ressalta-se o importante papel da outorga de lançamento de efluentes na melhoria da qualidade do corpo receptor, no entanto, a efetivação deste instrumento precisa de métodos e critérios claros e condizentes com as especificidades locais. No entanto, para que novas metodologias possam ser aplicadas e que suas análises sejam confiáveis é necessário que estas sejam discutidas entre os membros dos órgãos gestores responsáveis pelas análises, assim como levadas para o âmbito do comitê de bacia e demais setores envolvidos no planejamento dos recursos hídricos.

\subsection{Estudos desenvolvidos para a gestão da outorga de efluentes}

A partir da instituição da Lei 9.433/97, com o estabelecimento dos instrumentos de gestão, iniciou-se o desenvolvimento de estudos voltados para as técnicas metodológicas para aplicação e análise do processo de concessão de outorga de efluentes.

Em 1997, Kelmam apresentou um artigo intitulado como "Gerenciamento de Recursos Hídricos: Outorga e Cobrança", no qual foi desenvolvida uma proposta para a quantificação dos impactos qualitativos do lançamento de efluentes. Este trabalho foi o pioneiro no estudo para a quantificação de lançamento de efluentes e sua metodologia vem sendo utilizada ou adaptada por diversos trabalhos que o sucederam.

Ribeiro \& Lanna (2003) apresentam uma proposta metodológica para integrar os procedimentos de outorga dos direitos de uso da água nos seus aspectos quantitativos e qualitativos. Neste estudo, o critério de análise considerado para a concessão de uso foi uma quantidade de água necessária para diluir os efluentes (vazão de diluição) ao invés de outorgar o lançamento de efluentes. 
A proposta apresentada por Ribeiro \& Lanna (2003) indicou que além dos dados de monitoramento de quantidade e qualidade d'água é necessário o levantamento do cadastro de usuários, tanto em aspectos de quantidade como qualidade, que permitam a obtenção do balanço hídrico e da vazão necessária para diluir a carga lançada. Esta verificação permite estabelecer a concentração máxima para o lançamento de forma a atender as exigências estabelecidas pelo enquadramento. No estudo, foram discutidos critérios para a vazão máxima outorgável e critérios de racionamento para situações onde a vazão disponível não é suficiente para atender às vazões de captação e de diluição através da simulação de cenários.

Os critérios simulados por Ribeiro \& Lanna utilizaram as vazões $Q_{90 \%}$ mensal e $Q_{90 \%}$ anual par obter o limite máximo outorgágel, o limite máximo por trecho é $0,80 \mathrm{~m}^{3} / \mathrm{s}$, onde a vazão de referência $Q_{90 \%}$ mensal permitiu uma melhor caracterização do regime hidrológico para a bacia do Pirapama, localizada a região metropolitana de Recife/PE. Quando utilizado o critério de vazão de diluição, obteve-se que a vazão disponível para diluição dos efluentes, da maioria dos usuários da bacia do Pirapama, é insuficiente. Outro resultado deste estudo foi obtido através da simulação de cenários considerado a "flexibilização no enquadramento", isto é, permitindo valores acima da classe pré-definida. Estas simulações mostraram que mesmo considerando a violação dos limites estabelecidos pelo enquadramento não houve a redução no número de falhas no atendimento para o padrão de qualidade, mostrando a necessidade de redução de carga.

Conforme Ribeiro \& Lanna (2003), quando a outorga é analisada considerando a vazão de diluição e não existir água para diluir os efluentes da bacia, torna-se necessário definir algumas estratégias para o gerenciamento da qualidade da água na bacia. A seguir apresentam-se duas alternativas que podem ser usadas combinadas ou separadas:

- Racionamento dos lançamentos - modificação do processo produtivo, gerando menos efluente; tratamento de efluentes e/ou pagamento pela água necessária para diluir; aumento da eficiência ao usar água captada repassando uma parcela da vazão para diluição de efluentes.

- Flexibilização no enquadramento - fase conhecida como "etapalização da qualidade", caracterizada pela evolução gradual da qualidade do efluente tratado. Isto implica em permissão do órgão ambiental.

Diante da complexidade envolvida nas análises da outorga dos $\mathrm{RH}$, considerando seus aspectos de qualidade e quantidade, os modelos de simulação e otimização auxiliam o processo de forma positiva, uma vez que os mesmos possibilitam um melhor entendimento da situação conflitante e propiciam a análise de diversos cenários, adequando os usos e as disponibilidades, em termos de quantidade e qualidade, de maneira a minimizar os impactos e conflitos existentes. 
Seguindo esta linha de modelos matemáticos para auxiliar o processo de gestão de recursos hídricos, Rodrigues \& Porto (1999) desenvolveram uma ferramenta de auxílio para os processos de outorga e cobrança pelo uso da água para o caso de lançamento de poluentes não conservativos. O estudo teve como objetivo a determinação da vazão de diluição e da vazão liberada no sistema a jusante para novas outorgas, tendo em vista que a massa de poluente diminui no sistema à medida que vai se afastando do ponto de lançamento, devido ao processo de autodepuração do corpo hídrico.

A vazão de diluição, obtida por Rodrigues \& Porto (1999), foi calculada considerando-se as características físicas do sistema, a capacidade de autodepuração do corpo receptor, as taxas de sedimentação do poluente, a classe de uso do corpo receptor, o regime de vazão do corpo receptor, a vazão e a concentração do efluente, a qualidade do corpo receptor em que o mesmo é submetido, e a retirada de massa do sistema através de pontos de captação.

Ferraz \& Braga (1998) realizaram um trabalho que contribuiu para avaliar a importância do desenvolvimento e utilização de Sistemas de Suporte a Decisão (SSD). O sistema desenvolvido foi composto por um modelo matemático, um Sistema de Informação Geográfico (SIG) e um Sistema Especialista, onde foi proposto um Modelo Decisório específico para dar suporte ao gerenciamento e planejamento integrado dos recursos hídricos, no que se refere às metas de outorga do uso da água. Como conclusões deste estudo os autores apontaram a necessidade de informações da bacia hidrográfica em um modelo decisório para a comparação, análise e julgamento das alternativas para o uso racional e sustentável dos recursos hídricos. Os autores ainda ressaltaram a importância de unir as estruturas computacionais, como o Sistema de Informação Geográfico (SIG) e modelos matemáticos, em um sistema de suporte a decisão.

Nahon et al. (2009) apresentaram um sistema de apoio à análise de outorga de lançamento de efluentes para a variável Demanda Bioquímica de Oxigênio (DBO). $O$ sistema utilizou as equações do Modelo de Streeter-Phelps para fazer uma análise na Bacia do Alto Iguaçu. Os autores observaram que este sistema pode auxiliar inicialmente, em ocasiões e locais com deficiência de dados para calibração de modelos, nos processos de outorga de lançamento de efluentes até que haja condições suficientes (dados, equipe técnica, metodologia consolidada) para se utilizar novos modelos que representem melhor a qualidade das águas. Nesse estudo, foram utilizados coeficientes conservadores para proteção dos corpos aquáticos e o Modelo QUAL2E calibrado para a bacia em estudo. $O$ sistema testou quatro coeficientes e ainda fez uma análise de erros em dados hidráulicos (velocidade média).

$\mathrm{Na}$ análise da metodologia, proposta por Nahon et al. (2009), pode-se concluir que: a) foi obtido comportamento semelhante ao modelo Qual2E quando utilizados os mesmos 
coeficientes; b) para assegurar uma situação a favor da proteção dos recursos hídricos e da economia deve-se utilizar coeficientes conservadores, no caso da velocidade de sedimentação menor que $0,9 \mathrm{~m} / \mathrm{dia}$; c) o erro na determinação das vazões deve ser menor que $15 \%$.

Nahon et al. (2009) ressaltaram a possibilidades de iniciar os procedimentos de análise de outorga de lançamento de efluentes através de modelos simplificados, que considerem a autodepuração dos corpos aquáticos, assim como um fator de segurança elevado para não comprometê-los.

Rodrigues (2000) publicou o Modelo RM1, o qual calcula a vazão de diluição que será utilizada no lançamento de poluentes degradáveis ou conservativos em rios e, portanto, que deve estar sujeita à outorga. O modelo RM1 serviu de ferramenta chave para a construção do Sistema de Suporte a Decisão (SSD) RB.

O SSD RB é uma ferramenta de gestão quali-quantitativa para os processos de outorga e cobrança pelo uso da água, que viabiliza a articulação de todos os instrumentos de gestão. Segundo Rodrigues (2005), o SSD RB visa auxiliar e orientar os tomadores de decisão no processo de gestão de recursos hídricos, na inserção de dados de forma eficiente, assim como fornecer uma saída gráfica que permita uma visualização dos dados hidráulicos, classe de uso do rio, custos unitários, parâmetros e coeficientes, condições de cabeceira, fluxo incremental (poluição difusa) e condições iniciais do rio.

$\mathrm{Na}$ modelagem do SSD RB ocorre a integração dos modelos QUAL2E e RM1, visando à simulação de rios e/ou trechos de rios com cenários de vazões distintos. O SSD RB trata a outorga de lançamento e a outorga de captação a partir da variável de decisão, volume outorgado.

Cruz (2001) desenvolveu um modelo de balanço hídrico otimizado, o qual trata de um modelo de alocação de água levando em consideração a oferta hídrica e a demanda compondo assim a balanço hídrico. Segundo Cruz (2001), a otimização do balanço hídrico trás uma grande contribuição para a fase de planejamento de um sistema de outorga, assim como na área de planejamento estratégico de racionamentos de água nos períodos de estiagem. O cálculo é realizado em planilha eletrônica organizada e utiliza otimizadores para diferentes funções objetivo. O estudo realizado por Cruz (2001) apresentou duas funções objetivo para o balanço hídrico otimizado, as quais buscaram minimizar a diferença entre a vazão demandada e a outorgada, sendo os valores de vazões outorgadas a serem otimizados. Assim, otimiza-se a proporção de atendimento, mas não há otimização do resultado econômico da outorga. As funções desenvolvidas foram as seguintes:

- Função relativa: tem por característica tirar o peso excessivo dado aos valores absolutos da função, apresentada na Equação 4.1, enfatizando o melhor ajuste dos valores relativos (Tucci, 1998), proporcionando uma distribuição mais equânime entre 
os usuários. Neste caso, as seções com menores vazões de demanda tenderão a receber uma vazão proporcionalmente maior que as seções de grande demanda.

Sejam n seções i:

$$
\mathrm{F} 1=\sum_{\mathrm{i}=1}^{\mathrm{n}}\left(\frac{\mathrm{Q}_{\text {demanda }}(\mathrm{i})-\mathrm{Q}_{\text {outorgada }}(\mathrm{i})}{\mathrm{Q}_{\text {demanda }}(\mathrm{i})}\right)^{2}
$$

Onde:

- Qdemanda(i) é a vazão demandada na seção i;

- Qoutorgada(i) é a vazão outorgada na seção i.

- Função quadrática: tem por característica priorizar o ajuste dos valores maiores (Tucci, 1998). No problema da outorga, a equação privilegia os usuários das seções com maior demanda, com a tendência de outorgar uma vazão proporcionalmente maior. Sejam $n$ seções i:

$$
\mathrm{F} 2=\sum_{\mathrm{i}=1}^{\mathrm{n}}\left(\mathrm{Q}_{\text {demanda }}(\mathrm{i})-\mathrm{Q}_{\text {outorgada }}(\mathrm{i})\right)^{2}
$$

Equação 4.2

No caso da função relativa, tem-se a limitação matemática de uso quando o valor da demanda é zero. Para essas situações, adota-se a outorga de 100\%.

Para aplicação do modelo de balanço hídrico, existem restrições que precisam ser consideradas, aplicáveis a todas as seções i. São restrições clássicas, contudo precisam ser informadas à ferramenta que vai fazer a otimização para todas as seções de outorga:

- o valor a ser outorgado ( $\left.Q_{\text {outorgada }}\right)$ deve estar entre os limites de zero e o valor da demanda (Di) em cada seção: $0<Q_{\text {outorgada }}(\mathrm{i})<\mathrm{Di}$;

- a outorga (Q $Q_{\text {outorgada }}$ ) na seção acumulada com a dos usuários de montante deve estar entre os valores zero e a demanda da seção acumulada com a de seções a montante $\left(D i_{\text {acum }}\right): 0<Q_{\text {outorgada }}(i)<\mathrm{Di}_{\text {acum }}$.

O balanço hídrico concebido é facilmente equacionado em planilhas eletrônicas. Dessa forma, o modelo realiza o balanço hídrico entre a disponibilidade hídrica marco zero e a demanda requerida, onde o balanço pode ser realizado de montante para jusante, jusante para montante ou com otimização da vazão outorgada seguindo uma função objetivo definida pelo usuário do modelo. As respostas geradas são os valores a serem outorgados ou racionados.

Seguindo esta linha de modelos desenvolvidos para auxiliar o processo decisório, destaca-se o modelo de rede de fluxo AcquaNet. Segundo Porto et al. (2003) os modelos de rede de fluxo são uma classe de modelos de simulação que contêm algoritmo de otimização. Estes modelos caracterizam-se pela representação de sistemas de recursos 
hídricos a partir de uma rede formada de nós e arcos. Os nós representam reservatórios, demandas, reversões, confluências e outros pontos do sistema. Por outro lado, os arcos são os elos de ligação entre os nós, representando trechos de rio, adutoras, canais e outras estruturas.

Porto et al. (2005) relatam um breve histórico deste sistema, onde em sua fase inicial, o AcquaNet foi inspirado em um modelo de rede de fluxo denominado ModSim, desenvolvido na Colorado State University pelo professor John Labadie (Labadie, 1988 e 1995). Este modelo apresentou uma forma eficiente de resolver problemas complexos de rede de fluxo combinando simulação e otimização, de tal forma que acentua as vantagens de ambas as técnicas para a solução do problema de alocação da água. O algoritmo utilizado pelo modelo é de programação linear primal-dual conhecido como Out-of-Kilter (Labadie, 1988).

A primeira versão do ModSim apresentava uma interface muito pobre em razão da falta de recursos da linguagem de programação na qual foi desenvolvido. O algoritmo foi programado em Fortran para o sistema operacional DOS. Apesar do elevado potencial para analisar sistemas grandes, a entrada e a saída de dados eram de difícil manipulação. Porém, diante do grande potencial do ModSim, o mesmo foi incluído na linha de pesquisa do Laboratório de Sistemas de Suporte a Decisões da Escola Politécnica da USP (LabSid), na área de desenvolvimento de técnicas de análise de sistemas de recursos hídricos.

O AcquaNet funciona através de uma estrutura modular, na qual foram incorporandos modelos matemáticos para analisar diferentes problemas relacionados ao aproveitamento de recursos hídricos. Atualmente, essa estrutura modular é constituída de um módulo base, denominado AcquaNet, e de módulos para obtenção da alocação de água, avaliação da qualidade da água, determinação de alocação de água para irrigação, produção de energia elétrica e consideração de valores econômicos nas decisões de alocação (Porto et al., 2003).

O módulo de alocação de água, responsável pelo balanço hídrico, utiliza um algoritmo de otimização para minimizar o "custo" de alocação de água na rede e maximizar os benefícios associados ao seu uso, o algoritmo utilizado no modelo é o "Out-of-Kilter" (Porto \& Azevedo, 1997), que é uma variação de método Simplex e utiliza a técnica primaldual para minimizar o custo na rede de fluxo. 
O problema de otimização apresenta então a seguinte forma:

$$
\min \sum_{i=1}^{N} \sum_{i=1}^{N} C_{i j} x Q_{i j}
$$

Equação 4.3

Sujeito:

Ao balanço de massa em todos os nós $\mathrm{j}=1, \ldots ., \mathrm{N}$ - Rede Conservativa, isto é,

$$
\min \sum_{i=1}^{N} \sum_{i=1}^{N} C_{i j} x Q_{i j}
$$

Equação 4.4

E às vazões mínimas e máximas em todos os arcos $(i, j)$, para todos $i, j=1, \ldots \ldots, N,-$ Rede Capacitada, ou seja,

$$
\mathrm{I}_{\mathrm{ij}} \leq \mathrm{Q}_{\mathrm{ij}} \leq \mathrm{S}_{\mathrm{ij}}
$$

Sendo Qij = vazão que transita do nó j; Cij = custo (prioridade) da unidade de vazão que transita entre os nós i e j, $\mathrm{N}$ = número total de nós de rede; lij = limite inferios da vazão no arco ij; Sij = limite superior da vazão no arco ij e lj = conjunto de todos os nós com arcos que terminam no nó j; ( $\mathrm{X}$ lj significa que todos os nós i sejam elementos do conjunto lj) e Oj = ao conjunto de todos os nós com os arcos que se originam no nó j. Este módulo quantitativo de alocação de água foi denominado de AlocaLS.

Teixeira (2004) desenvolveu um módulo denominado de QualidadeCLS que é uma ferramenta computacional capaz de gerenciar integradamente os aspectos de quantidade e qualidade de água em uma bacia hidrográfica. Este módulo é capaz de determinar as concentrações de diversos parâmetros de qualidade de água, tais como DBO, OD, coliformes totais, fósforo total, algas, nitrogênio orgânico, amônia, nitrito e nitrato, em diversos pontos ao longo dos rios que compõem uma bacia.

Segundo Porto et al. (2003) os modelos de qualidade existentes, tal como o Qual2E e o OTIS, foram inicialmente analisados para integrar a plataforma do AcquaNet. Entretanto, devido às dificuldades de integração e de incompatibilidade de cenários em que tais modelos de qualidade trabalham em relação ao módulo de alocação do modelo de rede de fluxo, estes não puderam ser utilizados. A solução para o módulo de qualidade, QualidadeCLS, se dá através de um método analítico que consiste na utilização das fórmulas de decaimento exponencial.

O modelo de rede de fluxo OutorgaLS, plataforma generalizada para análise de outorga para captação de água e para lançamento de efluentes, é uma adaptação do modelo AcquaNet para o uso em análise de outorgas. O OutorgaLS tem suas análises 
focadas para a avaliação das vazões de referência ao invés de séries históricas como trabalha o AcquaNet.

A concepção do OutorgaLS teve como objetivo desenvolver uma plataforma para a análise de concessão de outorga para captação de água e para lançamento de efluente que possa ser utilizada em bacias hidrográficas com diversas características físicas e ambientais. O trabalho foi concebido visando a integração com banco de dados que contenham informações hidrológicas e cadastros de usuários em uma interface única que permita o uso de tecnologia de sistema de informações geográficas (Porto et. al 2006).

Assim como o Acquanet, o OutorgaLS tem seu processo de otimização focado para as análises quantitativas, onde a vazão de diluição não é considerada como uma variável decisória do processo de otimização.

Rodrigues \& Cardoso da Silva (2007) apresentaram o modelo ALOC Server que possibilita a aplicação da outorga e da cobrança pelo uso da água de forma mais sistemática. No ALOC Server são quantificadas as cargas e vazões alocadas ao longo do rio, considerando o processo de autodepuração, o regime de vazão, o enquadramento em classes de uso e a poluição difusa. Dessa forma, o sistema oferece a capacidade de racionalizar o custo do usuário, ao mesmo tempo em que induz a uma alocação eficiente dos recursos hídricos. No modelo não foi apresentado um algoritmo para otimizar a análises.

Como visto neste Item, muitos estudos foram desenvolvidos voltados para a outorga de diluição de efluentes, no entanto, estes estudos não levam em consideração o processo de otimização da qualidade da água no corpo hídrico. Em função desta constatação, esta tese visa o desenvolvimento de um SSD para o processo de outorga, o qual utiliza técnicas de otimização integrada dos aspectos quantitativos e qualitativos, e a formulação de alternativas, estratégias para uso dos recursos hídricos, visando à manutenção da classe do enquadramento no corpo hídrico e a minimização dos custos de tratamento de efluentes, assim como avaliar o impacto nos usos consuntivos.

A ferramenta proposta produziu um algoritmo capaz de analisar sistemas complexos, com diversas demandas quantitativas e lançamentos de efluentes. Assim, como resultado desta análise, obtem-se uma composição das captações e das eficiências de tratamento dos efluentes tendo em vista o menor impacto, em termos de qualidade do corpo receptor, custo de tratamento, e com o aproveitamento máximo da água disponível. Desta forma, o SSD desenvolvido contribui significativamente para a efetivação do instrumento de outorga de efluentes, através da inserção de critérios e estratégias de análise que visam o desenvolvimento sustentável. 


\section{ALGORÍTMOS EVOLUCIONÁRIOS PARA SUPORTE A DECISÃO}

Os sistemas de suporte a decisão em Recursos Hídricos são desenvolvidos com a finalidade de proporcionar aos gestores de recursos hídricos e aos tomadores de decisão uma ferramenta que possibilite a interação de um banco de dados com modelos matemáticos em uma interface gráfica adequada. Os SSDs possibilitam que os tomadores de decisão obtenham respostas de forma rápida e precisa, mesmo quando existem problemas complexos envolvendo diversas variáveis, como é o caso da gestão adequada dos recursos hídricos.

A complexidade das variáveis envolvidas na gestão de recursos hídricos, neste caso destaca-se a outorga de efluentes, é um desafio a ser superado pelas técnicas de otimização para o desenvolvimento dos SSDs. A busca de algoritmos que apresentem aptidão para a solução do problema é um processo delicado, pois estes apresentam vantagens e desvantagens, uma vez que o desempenho do algoritmo depende dos objetivos a serem alcançados e do problema a ser solucionado.

Segundo Loucks \& Beek (2005) existem muitas maneiras de classificar os vários tipos de modelos de otimização. Os modelos podem ser determinísticos ou probabilísticos ou uma mistura de ambos. Eles podem ser estáticos ou dinâmicos em relação ao tempo. Muitos modelos de gerenciamento de recursos hídricos são estáticos, mas incluem múltiplos períodos de tempo para obter a estatística dos vários impactos em um período de planejamento. Os modelos de otimização podem ser lineares ou não lineares. Eles podem consistir de variáveis contínuas ou discretas ou variáveis inteiras ou uma combinação de ambas. Qualquer que seja a natureza da otimização, elas têm em comum o fato de descrever situações onde existem várias soluções que satisfazem todas as restrições, no entanto, aspira-se encontrar a melhor solução, ou, pelo menos, um conjunto de soluções ótimas.

A otimização tem como vantagens diminuir o tempo dedicado ao projeto, possibilitar o tratamento simultâneo de uma grande quantidade de variáveis e restrições de difícil visualização gráfica, possibilitar a obtenção de algo melhor, obtenção de soluções não tradicionais e com menor custo (Samarano \& Prado, 2005).

Apesar de várias décadas de intensa pesquisa na aplicação de modelos de otimização em sistema de reservatórios, autores como Yeh (1985), Wurbs (1993) e Labadie (2004) notaram uma grande lacuna entre avanços teóricos e aplicações no mundo real. Algumas causas destas disparidades podem ser:

- Desconfiança dos operadores em relação a modelos que propõem trocar o seu julgamento por outras estratégias operacionais.

- Restrições computacionais (software e hardware) no passado impuseram 
simplificações e aproximações que os operadores se recusavam a aceitar.

- Os modelos de otimização são matematicamente mais complexos do que os modelos de simulação e, conseqüentemente, mais difíceis de entender.

- Muitos modelos de otimização não incorporam riscos e incertezas.

- A grande variedade de métodos de otimização cria confusão na seleção apropriada para uma aplicação específica.

- Alguns métodos de otimização necessitam programação para serem utilizados.

- Muitos métodos de otimização não conseguem gerar regras de operação.

Segundo Labadie (2004) muitos destes problemas citados estão sendo superados com a utilização de técnicas de otimização integradas aos sistemas de suporte a decisão, aliado ao grande avanço dos hardwares e softwares dos computadores pessoais.

Técnicas clássicas de otimização são confiáveis e possuem aplicações nos mais diferentes campos de engenharia e de outras ciências. Porém, estas técnicas podem apresentar algumas dificuldades numéricas e problemas de robustez relacionados à falta de continuidade das funções a serem otimizadas ou de suas restrições, às funções não convexas, à existência de ruídos nas funções, à necessidade de se trabalhar com valores discretos para as variáveis, à existência de mínimos ou máximos locais, entre outros (Samarano \& Prado, 2005).

Nos últimos anos, a procura por novas técnicas de otimização capazes de alcançar o ótimo global para solução de problemas complexos de recursos hídricos tem sido o foco principal de muitas pesquisas. Entre estas técnicas, destacam-se os chamados Algoritmos Evolutivos, que apresentam respostas satisfatórias para diversos problemas de recursos hídricos, como observado por Ranjithan (2005) e Simonovic (2008).

Os algoritmos evolutivos (AEs) são um subconjunto da computação evolutiva, podem ser considerados como um algoritmo de otimização genérico de base populacional metaheurística. Um AE utiliza mecanismos análogos à evolução biológica como a reprodução, mutação, recombinação e seleção.

Os AEs baseiam-se em uma população inicial de indivíduos (conjunto de soluções), sobre a qual desencadeiam-se processos de seleção natural e estes processos sofrem com a interferências e pressões do ambiente (ou seja, um processo que privilegia as melhores soluções até então encontradas), o que causa a busca e adequação das soluções para um objetivo definido. Dada uma função a ser otimizada (maximizada ou minimizada), gera-se aleatoriamente um conjunto de soluções, isto é, elementos pertencentes ao domínio da função, e aplica-se a função para medir a qualidade das soluções candidatas, atribuindoIhes um valor que mede sua adequação, chamado de aptidão ou fitness.

Com base na aptidão, algumas das melhores soluções são selecionadas para darem origem a uma nova população pela aplicação de operadores de recombinação e/ou 
mutação. A recombinação é um operador aplicado a duas ou mais soluções candidatas (chamadas pais) e resulta em duas ou mais novas soluções (chamadas descendentes ou filhos). A mutação é aplicada a uma candidata a fim de gerar outra. Ao final desse processo, as novas soluções candidatas (descendentes) competem com as candidatas da geração anterior, com base na função de aptidão, para assumir um lugar na nova população. Esse processo é iterado até que uma candidata apresente uma solução que seja suficientemente qualificada ou até que um número máximo de iterações, também chamadas gerações, seja obtido.

Durante as últimas duas décadas, houve um aumento significativo no desenvolvimento e aplicação de vários tipos de algoritmos evolutivos para utilização no processo de gestão de recursos hídricos.

Os algoritmos evolutivos inseridos nas análises do SSD proposto para o sistema de outorga de efluentes foram o Particle Swarm Optimization (PSO), o Algoritmo Genético (AG) e o Differential Evolution (DE). Estes algoritmos foram escolhidos por serem de fácil implementação e comprovadamente aplicáveis aos problemas de recursos hídricos. Por se tratarem de algoritmos evolucionários são baseados em populações e utilizam operadores de seleção, mutação e cruzamento para realizar a busca do valor ótimo da função objetivo, Simonovic (2008).

De forma geral, os métodos de otimização baseados em técnicas evolutivas, como Algoritmos Genéticos, Particle Swarm Optimization e Differential Evolution, requerem maior esforço computacional quando comparados a outros métodos clássicos, mas apresentam vantagens, tais como, a fácil implementação, a robustez e não requerem que o espaço de busca seja obrigatoriamente contínuo (Venter \& Sobieszczanski-Sobieski, 2002, apud Samarano \& Prado, 2005).

A crescente utilização dos AEs na área de recursos hídricos pode ser constatada com o crescente número de publicações, os quais vêm sendo aplicados com sucesso em projetos e operação de abastecimento de água e estações de tratamento de águas residuais e de outros problemas de gestão da qualidade da água.

Os AEs foram aplicados para a concepção de efluentes industriais, identificando as configurações das estações de tratamento de águas residuais e incorporando o reuso de água no processo produtivo, minimizando assim a descarga de efluentes (Tsai Chang, 2001; Li et al., 2003; Lavric et al., 2005.).

Guria et al. (2005) aplicaram Algoritmo Genético para identificar as membranas e as características operacionais de sistemas de osmose reversa em estações de dessalinização de água. Suggala \& Bhattacharya (2003) aplicaram AGs para identificar os custos de remoção de organismos de águas residuais para atender aos padrões de remoção de poluentes. 
Chen et al. (2003) e Chang et al. (2001) utilizaram AEs para avaliar o funcionamento de uma usina de tratamento de águas residuais domésticas, assim como, investigaram o uso de AG para identificar estratégias de controle em tempo real de parâmetros como: $\mathrm{pH}$, teores de nutrientes, consumo de eletricidade, e os caudais de efluentes, para atender padrões de efluentes, assim como os objetivos de custos.

Mulligan et. al (1998) fizeram uma aplicação utilizando algoritmos genéticos para calibração dos parâmetros de qualidade da água oxigênio dissolvido (OD) e demanda bioquímica de oxigênio (DBO). As conclusões deste estudo demonstraram que o AG obtém ótimas estimativas em problemas de otimização não linear com diversas restrições.

Kondageski \& Fernandes (2007) desenvolveram rotinas de algoritmo genético para calibração de um modelo de qualidade da água para um rio hipotético, apresentado por Chapra (1997), dividido em trechos. Neste estudo, foram definidos 5 cenários, para os quais foram realizadas 200 simulações. Foram empregados diferentes números de pontos de monitoramento para a calibração do modelo. Observou-se que para os cenários com maior número de pontos de monitoramento as constantes de qualidade calculadas apresentaram forte relação linear entre si. Além disso, as concentrações de DBO e OD calculadas com as médias das constantes aproximaram-se dos valores monitorados destas concentrações.

Sowinski \& Neugebauer (2007) aplicaram o Modelo WODA (Water Oxidation Deoxidation Assessment) com a finalidade de obter a calibração automática dos parâmetros OD e DBO. O Modelo WODA utiliza o algoritmo genético para a otimização da função objetivo. O modelo foi aplicado para a determinação dos parâmetros do Rio Warta na Polônia, onde foram encontrados bons ajustes na comparação dos valores calculados e observados.

Nicklow et al. (2010) apresentam uma revisão detalhada do estado-da-arte dos métodos e aplicações de algoritmos genéticos na área de planejamento de recursos hídricos e de gestão. Os autores identificaram de forma organizada algumas das contribuições dos algoritmos evolucionários, com ênfase aos algoritmos genéticos, nas áreas de sistemas de distribuição de água, drenagem urbana, sistemas de esgoto, abastecimento de água, tratamento de águas residuárias, modelagem hidrológica e fluvial, sistemas de águas subterrâneas e identificação de parâmetros.

A seguir são apresentados os Algoritmos Evolutivos que foram inseridos no SSD para Outorga de Efluentes proposto nesta tese, tendo em vista os resultados otimizados na integração dos aspectos de quantidade e qualidade da água, assim como na alocação da carga poluente e na minimização dos custos das medidas de tratamento de efluentes. 


\subsection{Algoritmos Genéticos AGs}

Os Algoritmos Genéticos (AGs) foram introduzidos por John Holland (Holland, 1975) e popularizados por um dos seus alunos, David Goldberg (Goldberg, 1989). Estes algoritmos são métodos de otimização e busca, os quais são inspirados nos mecanismos de evolução de população de seres vivos, estes métodos seguem o princípio da seleção natural e sobrevivência do mais apto, declarado em 1859 pelo naturalista e fisiologista inglês Charles Darwin em seu livro "A origem das espécies". (Lacerda et al., 1999).

Loucks \& Beek (2005) explicaram o funcionamento dos algoritmos genéticos. As explicações a seguir foram obtidas desse texto. Conforme os autores, diferentemente da otimização convencional, os AG tem sua abordagem baseadas em gradientes, trabalhando sobre uma população de possíveis soluções para tentar maximizar ou minimizar o valor de uma função objetivo. As soluções que melhoram o desempenho da função objetivo possuem um papel mais importante na geração de novas populações.

Cada conjunto de indivíduos de uma solução contém os valores de todos os parâmetros ou variáveis, cujos melhores valores estão sendo procurados. Estas soluções são expressas como um vetor ou cadeia de caracteres. Por exemplo, se os valores de três variáveis $x, y$ e z são obtidos, estas variáveis são arranjadas em um vetor, xyz. Se cada variável é expressa utilizando três dígitos, então o vetor 056004876 representaria $x=56, y=$ 4 , e $z=876$. Estas seqüências são chamadas de cromossomos. Um cromossomo é um vetor ou cadeia de números.

Os números nos cromossomos são chamados genes. Os cromossomos podem unirse a partir de dois pares e produzir descendentes, que por sua vez herdam alguns dos genes dos pais. Alterar genes pode resultar na melhoria dos valores da função objetivo. Esses genes tenderão a sobreviver de geração em geração, enquanto que aqueles que são inferiores tendem a morrer.

A população inicial de possíveis soluções viáveis é gerada aleatoriamente. Um dos parâmetros do AG é o tamanho da amostra (população) da solução - o número de soluções a ser considerado. Os melhores valores dos parâmetros do algoritmo genético são normalmente determinados por tentativa e erro.

Os genes dos filhos são determinados por operações de cruzamento "crossover" e mutação. Essas operações, cruzamento e mutação, são aleatórias e suas probabilidades de ocorrência são parâmetros do algoritmo genético.

Esta seleção ou mecanismo de reprodução tende a transferir para a próxima geração os melhores indivíduos da geração atual. Quanto maior a aptidão (ou seja, melhor resposta para a função objetivo) de um indivíduo, maiores serão as chances que este indivíduo seja selecionado para a próxima geração. 
Os algoritmos genéticos envolvem repetições das operações descritas acima, onde cada iteração (ou geração) produz populações que tendem a conter as melhores soluções. A melhor solução de todas as populações deve ser armazenada. A rotina do AG pode terminar quando não há alterações significativas nos valores da melhor solução que foi encontrada. Os critérios de parada são impostos ao algoritmo para evitar um esforço computacional desnecessário, mas estes não garantem que a melhor solução encontrada seja o ótimo global. O processo descrito pode ser visualizado no fluxograma da Figura 5.1.

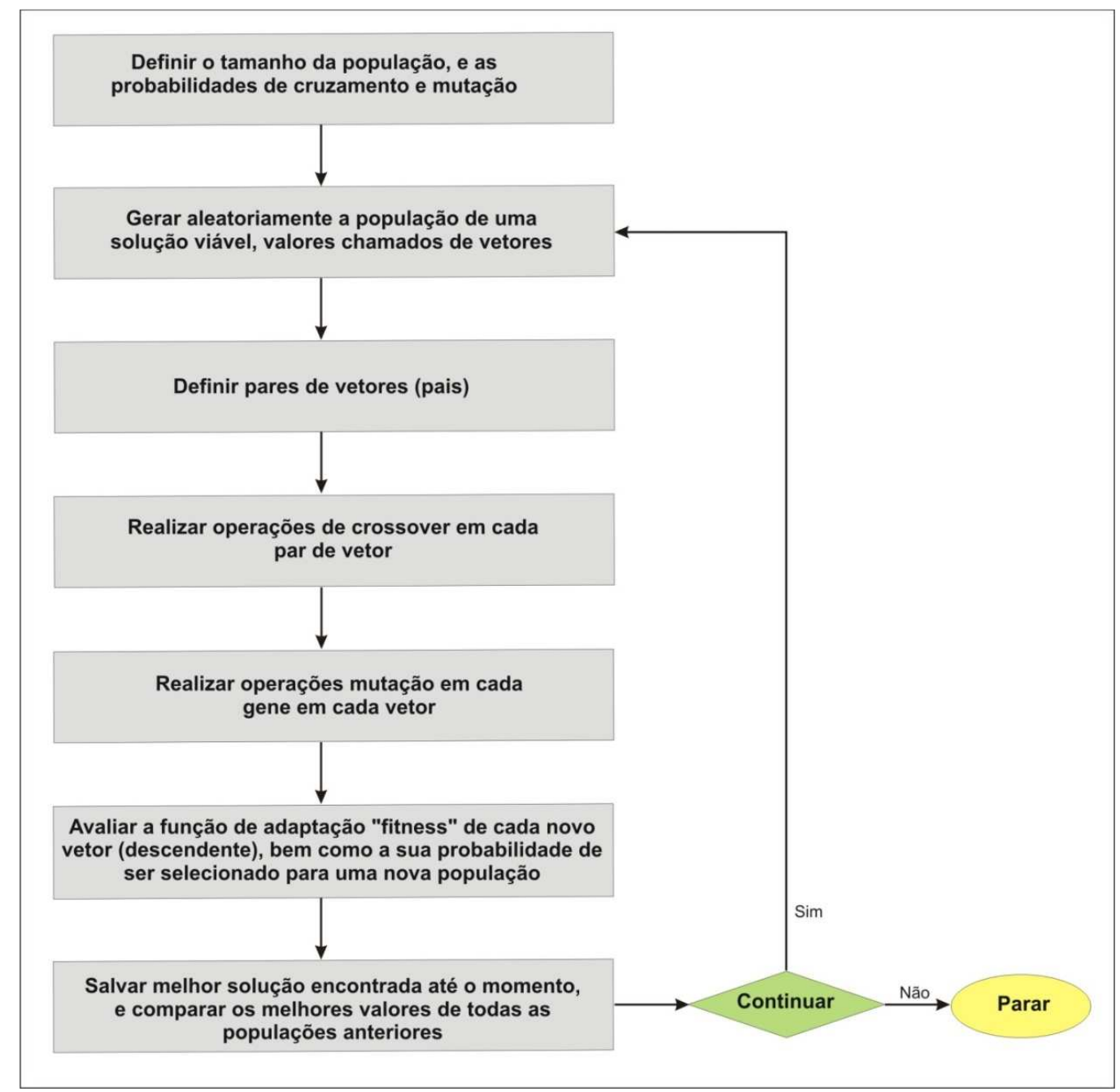

Figura 5.1 - Fluxograma do algoritmo genético AG (Fonte: Adaptado de Loucks \& Beek, 2005)

Os AGs têm sido empregados em problemas complexos de otimização, em que, geralmente, outros métodos falham. Lacerda \& Carvalho (1999) apresentaram as seguintes vantagens dos AGs:

- Funcionam tanto como parâmetros contínuos com discretos ou uma combinação deles.

- Realizam buscas simultâneas em várias regiões do espaço de busca, pois trabalham com uma população e não com um ponto único; 
- Utilizam informações de custo e recompensa;

- Não é necessário conhecimento matemático aprofundado do problema considerado;

- Otimizam um grande número de variáveis;

- Otimizam parâmetros da função objetivo com superfícies complexas e complicadas, reduzindo a incidência de mínimos locais;

- Adaptam-se bem a computadores paralelos;

- Trabalham com uma condição de conjunto de parâmetros, e não com os próprios parâmetros;

- Fornecem uma lista de ótimos e não uma simples solução;

- Trabalham com dados gerados experimentalmente e são mais tolerantes a ruídos e dados incompletos;

- São fáceis de serem implementados em computadores;

- São modulares e portáteis, no sentido que o mecanismo de evolução é separado da representação particular do problema considerado. Assim, eles podem ser transferidos de um problema para outro;

- São flexíveis para trabalhar com restrições arbitrárias e otimizar múltiplas funções com objetivos conflitantes.

Apesar dessas vantagens mencionadas, os AGs não são eficientes para alguns problemas, e muito lentos para a solução de outros. O principal campo de aplicação dos AGs é em problemas complexos, com múltiplos mínimos/máximos e para os quais não existe um algoritmo eficiente conhecido para resolvê-los. A seguir, são apresentados os principais componentes dos algoritmos genéticos.

Como todo algoritmo evolutivo, os AGs trabalham com um conjunto de pontos. Uma população no tempo $t, P(t)$, é composta por indivíduos que competem entre si no mesmo espaço de busca. Nesta população têm-se os seguintes elementos:

- $P(t)=\left(x_{1}^{t}, x_{2}^{t}, x_{3}^{t}, x_{4}^{t}, \ldots \ldots x_{n}^{t}\right)$ - população no espaço de busca;

- $x_{i}^{t}=\left(g_{1}^{t}, g_{2}^{t}, g_{3}^{t}, g_{4}^{t}, \ldots . . . g_{n}^{t}\right)$ - cromossoma $x_{i}^{t}$, candidato à solução do problema de otimização, no qual $g_{j}^{t}$ representa um gene que equivale a uma variável da solução;

- Espaço de busca ou região viável - espaço ou região que compreende as soluções possíveis ou viáveis do problema a ser otimizado;

- Geração - ciclo executado pelo algoritmo genético para gerar uma nova população;

- Função objetivo ou de aptidão - função que se deseja otimizar. Ela fornece a informação numérica do desempenho de cada indivíduo da população. Através do seu valor, é possível avaliar quão apto é um indivíduo a ser selecionado para 
reprodução:

$$
F O=f\left(x_{1}^{t}, x_{2}^{t}, x_{3}^{t}, x_{4}^{t}, \ldots . . . x_{n}^{t}\right)
$$

Sendo $\left(x_{1}^{t}, x_{2}^{t}, x_{3}^{t}, x_{4}^{t}, \ldots \ldots x_{n}^{t}\right)$ as possíveis soluções que o algoritmo procura determinar, para otimizar FO. Esta função objetivo é, em princípio, calculada para cada indivíduo da população.

A população inicial é gerada aleatoriamente, formando os conjuntos de vetores que contem as variáveis de decisão do problema proposto, estes vetores são chamados de cromossomos. Os valores da população inicial respeitam os limites mínimos e máximos impostos às variáveis. O tamanho da população adotado foi de dez vezes o número de variáveis.

O operador de cruzamento "crossover" é aplicado a um par de indivíduos selecionado da população, onde estes indivíduos são responsáveis pela geração de novos indivíduos, através da combinação das informações genéticas para geração de filhos.

Para a geração de indivíduos diferentes (melhores ou piores) o cruzamento pode ser considerado um dos principais operadores do algoritmo genético aplicado aos indivíduos de uma população. Na representação dos cromossomos, binária e real, existem vários tipos de operadores de cruzamento.

No cruzamento em múltiplos pontos, são selecionadas diferentes posições de forma aleatoriamente e ordenadas de forma ascendente, e assim os genes entre os pontos de cruzamento sucessivos são trocados entre os dois pais para produzir dois novos descendentes.

No cruzamento uniforme não são utilizados pontos de corte e cada indivíduo é gerado com a probabilidade de herdar $50 \%$ do gene de cada um dos pais.

O cruzamento aritmético produz um tipo de combinação linear entre os cromossomos pais para a geração dos filhos, este método é utilizado para a representação real.

Os operadores de mutação são necessários para a manutenção da diversidade genética da população. Esta operação possibilita que os genes dos descendentes gerados sofram mutação com uma pequena probabilidade de modo a evitar que o processo de busca torne-se puramente aleatório (Cunha, 2006).

Segundo Loucks \& Beek (2005) a mutação tem a função de explorar um novo domínio no espaço, evitando assim que o algoritmo fique restrito a buscar soluções em uma região com ótimos locais. Os autores ainda alertam que a mutação pode ser destrutiva, causando uma rápida degradação do ajuste da solução, isto pode ocorrer se a probabilidade de mutação no algoritmo for muito elevada. A seleção dos indivíduos para reprodução consiste em determinar os indivíduos de uma população que obtiverem melhor desempenho na função de aptidão. Na seleção por torneio, os indivíduos são escolhidos aleatoriamente e 
com probabilidades iguais. Entre os indivíduos escolhidos, aquele que apresentar maior aptidão é selecionado, ou seja, é dito que ele venceu o torneio. Na seleção proporcional à aptidão é criada através de uma "roleta", onde cada indivíduo da população possui uma fração proporcional à sua aptidão. Após isto, "gira-se esta roleta" e, devido ao fato dos indivíduos com maiores aptidões possuírem uma área maior da roleta, eles têm maiores possibilidades de serem selecionados (Lacerda \& Carvalho, 1999).

A avaliação da função de aptidão ("fitness") em algoritmos genéticos é o mecanismo que possibilita a escolha dos indivíduos aptos para a solução do problema ou com as características para serem repassadas para as próximas gerações. Segundo Cunha (2006), a função de aptidão é composta por uma função objetivo e outra função penalidade para os indivíduos não viáveis.

Assim, através da função de aptidão são selecionados os melhores indivíduos da população que sobrevivem a cada geração e estão aptos de gerar descendentes. Segundo Lacerda \& Carvalho (1999), entre as diversas maneiras de selecionar os indivíduos mais aptos podem ser consideradas mais usuais a seleção por torneio e a seleção proporcional à aptidão (ou seleção roda da roleta).

De acordo com Lacerda \& Carvalho (1999), na substituição de uma geração, toda a população é substituída pelos novos descendentes, ou seja, são gerados $\mathrm{N}$ filhos para substituir os $\mathrm{N}$ pais. Também pode ser analisada a alternativa de substituição da população atual pela composição dos melhores indivíduos entre os $\mathrm{N}$ pais e os $\mathrm{N}$ filhos. Para isso, é necessário preservar a informação genética do melhor indivíduo dentre os ascendentes, pais, repassando-o para a próxima geração, operação esta chamada de elitismo.

Após a obtenção de uma nova geração (através dos operadores de cruzamento e mutação) a população atual é substituída pela nova geração. Esta substituição é realizada através da eliminação dos indivíduos menos aptos (função aptidão) e preservação dos mais fortes.

O comportamento dos AGs é influenciado por alguns parâmetros, que devem ser analisados para que possam ser estabelecidos de acordo com as necessidades do problema. Estes parâmetros são:

- Tamanho da população: representa o número de indivíduos em cada geração. É um parâmetro que pode ser considerado crítico para o desempenho do AG, pois afeta seu desempenho global e sua eficiência. Uma população pequena fornece uma pequena cobertura do espaço de busca do problema, podendo convergir prematuramente. Quando se trabalha com uma população considerada de tamanho adequado se obtêm uma cobertura representativa do domínio do problema, além de prevenir convergências prematuras para soluções locais ao invés de globais. Por outro lado, quanto maior a população, maior o tempo total de processamento. 
- Taxa de cruzamento: relacionada à taxa de introdução de novos indivíduos na população (quanto maior mais rapidamente estes serão introduzidos). Deve-se tomar cuidado com o valor da taxa de cruzamento, pois valores muito altos podem favorecer a exclusão de bons cromossomos de forma mais rápida; por outro lado, valores baixos podem tornar o algoritmo muito lento.

- Taxa de mutação: Uma baixa taxa de mutação adequada previne que o algoritmo fique limitado a um ótimo local (convergência prematura), além de possibilitar que se chegue em qualquer ponto do espaço de busca. Com uma taxa muito alta a busca se torna essencialmente aleatória, e a solução ótima só é atingida com grande número de gerações.

- Critério de parada: informa ao algoritmo quando a execução deve ser encerrada. Este critério ocorre quando o $A G$ atinge um valor ótimo da função objetivo ou um valor considerado ótimo, um número máximo de gerações consecutivas sem melhoria da melhor solução. Existem outros critérios baseados no número máximo de gerações e no número máximo de novos indivíduos gerados.

\subsection{Particle Swarm Optimization (PSO) ou "Otimização por Nuvem de Partículas"}

O Particle Swarm Optimization foi proposto por Kennedy \& Eberhart (1995). O PSO é um algoritmo evolucionário que surgiu da análise de experiência com algoritmos que modelam o "comportamento social" observado na formação de vôo de um bando de pássaros. O PSO possui similaridades com o AG, apesar de não possuir operadores genéticos, sua população evolui no espaço de busca através da melhoria das posições das partículas, a cada iteração, rumo a melhores soluções.

Em síntese, no algoritmo PSO cada partícula é tratada como um ponto no espaço e ajusta seu vôo baseado na própria experiência e na experiência coletiva. A cada iteração, a atualização da posição da partícula ocorre pelo acréscimo da velocidade (taxa de variação da posição) em todas as dimensões. Isto faz com que ela tenda gradualmente para os melhores valores históricos, posição que possui o melhor valor de aptidão para a solução do problema (pbest), e para a melhor partícula prévia dentre todas as partículas da população (gbest).

O algoritmo possui, inicialmente, uma população (bando) de soluções potenciais (partículas) com suas respectivas posições. A cada uma delas é atribuída uma velocidade e as partículas passam a se movimentar pelo espaço de busca. Cada uma das partículas possui uma "memória", armazenando nesta a sua melhor posição prévia (pbest) e o bando também possui alguma espécie de "memória coletiva", onde se registra a melhor posição prévia já alcançada pelo bando (gbest). 
A cada iteração, a atualização da partícula $i$ dá-se pelo acréscimo da velocidade (taxa de variação da posição), em todas as dimensões, fazendo com que ela tenda gradualmente para melhores valores históricos, ou seja, pbest e gbest.

A Figura 5.2 apresenta um fluxograma do comportamento do algoritmo do PSO.

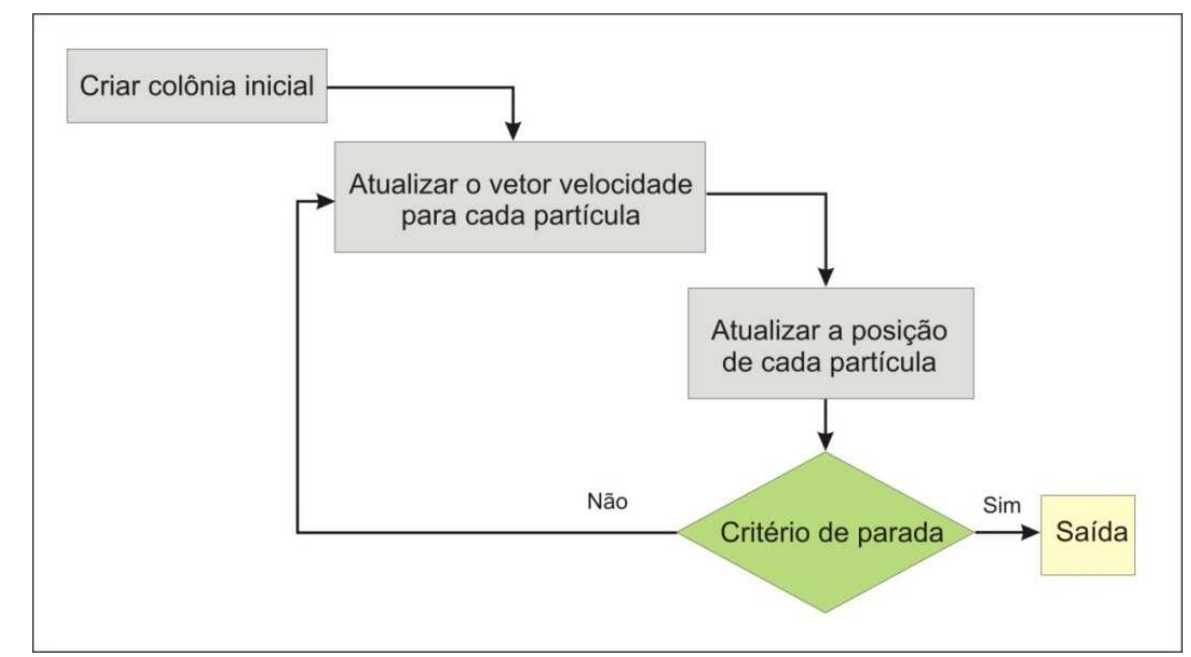

Figura 5.2 - Fluxograma do algoritmo PSO (Fonte: Adaptado de Samarano e Prado, 2005)

As etapas de solução de um problema pelo PSO são basicamente:

- Inicia se randomicamente a posição e a velocidade das N partículas da população;

- Avaliar indivíduos através do cálculo da função objetivo: $f(x)$;

- Atualizar a posição que possui o melhor valor de aptidão para a solução do problema pbest;

- $\operatorname{Se} f\left(x_{i}\right)<f\left(p b e s t_{i}\right)$ então pbest $t_{i}=x_{i}$;

- Atualizar gbest, melhor partícula prévia dentre todas as partículas da população;

- $\quad$ Se pbest $t_{i}<$ (gbest) então gbest = pbest;

- Atualizar a velocidade de cada partícula, conforme Equação 5.1;

- Atualizar a posição de cada partícula, conforme Equação 5.2;

- Enquanto o critério de parada não atingido nova interação

Onde:

- $\mathrm{X}_{\mathrm{i}}=\left(\mathrm{x}_{\mathrm{i} 1}, \mathrm{x}_{\mathrm{i} 2}, \ldots, \mathrm{X}_{\mathrm{iN}}\right)$ : partícula $\mathrm{i}$, candidata à solução do problema, na qual $\mathrm{x}_{\mathrm{iN}}$ representa uma variável da solução;

- $P_{\mathrm{i}}=\left(\mathrm{p}_{\mathrm{i} 1}, \mathrm{p}_{\mathrm{i} 2}, \ldots, \mathrm{p}_{\mathrm{iN}}\right)$ : melhor posição prévia de cada partícula, pbesti (posição que possui o melhor valor de aptidão para a solução do problema). A melhor partícula prévia dentre todas as partículas da população é representado pelo símbolo g e mostra a posição da melhor partícula do bando. A posição Pg é também chamada de gbest, (Eberhart \& Kennedy, 1995). 
- $\mathrm{V}_{\mathrm{i}}=\left(\mathrm{V}_{\mathrm{i} 1}, \mathrm{v}_{\mathrm{i} 2}, \ldots, \mathrm{V}_{\mathrm{iN}}\right)$ : velocidade ou taxa de variação da posição da partícula $\mathrm{i}$.

A Equação 5.1 atualiza a velocidade (v) para cada iteração $(\mathrm{k})$ para cada partícula e a Equação 5.2 atualiza a posição da partícula na iteração (k) Shi \& Eberhart (1998):

$$
\begin{gathered}
v_{k+1}^{i n}=w v_{k}^{i n}+c_{1} r_{1}\left(\text { pbest }^{i n}-x_{k}^{i n}\right)+c_{2} r_{2}\left(\text { gbest }^{n}-x_{k}^{i n}\right) \\
x_{k+1}^{i n}=x_{k}^{i n}+v_{k+1}^{i n}
\end{gathered}
$$

Onde os parâmetros são:

- w é o coeficiente de inércia (peso inercial), que é importante para definir o espaço de busca (quanto maior w maior será o número de solução examinadas), controla 0 impacto da velocidade prévia na velocidade corrente;

- c1 e c2 são constantes (geralmente de valor 2), parâmetros cognitivo e social, respectivamente;

- $\quad$ r1 e r2 são valores randômicos entre 0 e 1;

- pbest é o melhor vetor da partícula i;

- gbest é o melhor posição do bando, ou seja o melhor vetor de todas as partículas analisadas;

- $\mathrm{k}=1,2, \ldots$,itermax: número de iteração corrente, com o limite máximo igual a itermax;

- i: índice da partícula que varia de 1 até $\mathrm{N}$, onde $\mathrm{N}$ é o tamanho do bando;

- $\mathrm{n}$ : dimensão da partícula;

- $\quad x_{k}^{i n}$ : vetor corrente da partícula $\mathrm{i}$;

- $\mathrm{V}_{\mathrm{k}}^{\text {in }}$ : velocidade da partícula.

A Equação 5.1 tem função de atualizar a velocidade da partícula (i). O primeiro termo da equação $\left(V_{k}{ }^{i n}\right)$ corresponde à velocidade prévia da partícula ponderada pelo peso inercial (w). O segundo e o terceiro termos representam o conhecimento individual (herança de cada indivíduo) e o conhecimento adquirido entre todas as partículas (bando), respectivamente.

Os valores de $w$ influenciam o comportamento do algoritmo, alguns autores sugerem que o valor inicial seja alto e vá diminuindo com as iterações do modelo, aumentando as chances de se obter o ótimo global.

O cálculo da velocidade necessita de alguns parâmetros dependentes do problema, que são:

- a inércia da partícula (w), que controla a capacidade do algoritmo explorar o espaço 
de busca, ou seja, um valor alto determina um comportamento mais global, enquanto um valor baixo facilita um comportamento mais local, e

- os dois parâmetros de confiança c1 e c2, as quais indicam o quanto uma partícula confia em si e no bando, respectivamente.

Os valores recomendados para o peso inercial devem estar entre $0.7<\mathrm{w}<1.4$.

Os parâmetros de confiança e de inércia devem ser ajustados de acordo com o problema, pois são utilizados para a atualização do vetor velocidades. Alguns autores propõem que sejam adotados $c_{1}=c_{2}=2$, mantendo assim o equilíbrio entre o aprendizado individual de cada partícula e o aprendizado do bando. Sugere-se, também, a adoção de valores diferentes para $c_{1}$ e $c_{2}$ desde que a soma de $c_{1}$ e $c_{2}$ aproxime se de 4 .

Quanto maior o número $\mathrm{N}$ de partículas presentes na população (bando), menor será o número de iterações necessário para alcançar a solução do problema tratado, pois uma quantidade maior de partículas é envolvida na procura de uma solução. Desse modo, há um aumento na possibilidade de se encontrar uma solução para o problema. Neste estudo adotou-se o tamanho da população igual a dez vezes o número de variáveis. A população deve ter tamanho suficiente para varrer o espaço de busca, mas seu tamanho não deve se elevar ao ponto de trazer custos desnecessários para o processo de otimização.

\subsection{Differential Evolution DE}

O Differential Evolution (DE) foi proposto por Price \& Storn (1997) e é um dos algoritmos evolucionários mais recentes para solução de problemas de otimização com valores reais. O DE utiliza um operador de mutação simples baseado nas diferenças entre os pares de solução, também chamado de vetores, no intuito de encontrar a direção de busca com base na distribuição de soluções na população corrente.

Diferentemente do AG, que depende fortemente do operador de cruzamento, o DE utiliza a mutação como principal mecanismo de busca e a seleção para indicar a direção dentro da região viável do espaço de decisão.

O DE é baseado em populações e utiliza $N p$ variáveis e $D$ vetores de parâmetros para cada geração. A população inicial é gerada aleatoriamente, caso nenhuma informação a respeito do problema esteja disponível. Caso seja possível obter alguma informação do estado inicial do problema, a população é gerada introduzindo perturbações aleatórias nesta solução inicial.

A idéia básica do DE é um novo esquema para a geração do chamado vetor de testes. O DE gera este novo vetor a partir de dois membros da população. Se o vetor de testes possui um valor de função objetivo superior a um vetor pré-determinado da 
população, este substituirá o vetor ao qual esta sendo comparado. Além disso, a cada geração o vetor com a melhor função objetivo é sempre avaliado para manter o registro do progresso, realizado durante o processo de otimização. Utilizar a informação da distância e direção da população para gerar derivações randômicas resulta em um esquema adaptivo com propriedades excelentes de convergência (Price et al., 2005).

A implementação original do DE mantém um par de vetores da população, ambos contendo $N p$ parâmetros e dimensão $D$ com valores de parâmetros (ou variáreis) em representação real. A população corrente, representada por $P_{x}$ é composta por vetores, $X_{i, g}$, conforme Equação 5.3, e $P_{u}$ representa a população de teste que é composta por vetores de teste, representados por $U_{i, g}$, como mostra a Equação 5.4.

$$
\begin{aligned}
& P_{x, g}=\left(X_{i, g}\right), \quad i=0,1, \ldots, N p-1, g=0,1, \ldots, g \max , \\
& X_{i, g}=\left(x_{j, i, g}\right), \quad j=0,1, \ldots, D-1 \\
& P_{u, g}=\left(U_{i, g}\right), \quad i=0,1, \ldots, N p-1, g=0,1, \ldots, g \max , \\
& U_{i, g}=\left(x_{j, i, g}\right), \quad j=0,1, \ldots, D-1
\end{aligned}
$$

Equação 5.4

A população inicial é gerada aleatoriamente a partir dos limites mínimos e máximos de cada variável de decisão (caso não exista informação do problema disponível), conforme Equação 5.5.

$$
x_{i, i, 0}=\operatorname{rand}(0,1) *\left(b_{j, U}-b_{j, L}\right)+b_{j, L}, \quad j=0,1, \ldots, D-1
$$

No DE a mutação é utilizada para criar uma população de $N_{p}$ vetores de teste. A formulação original utiliza três vetores escolhidos aleatoriamente para criar o vetor mutante $V_{i, g}$, como descrito na Equação 5.6. O fator de escala da mutação $F$ utilizado é um número real, geralmente entre 0 e 1 (Vasan \& Simonovic, 2008) e determina a evolução da população ao longo das gerações. Os índices dos vetores $r_{0}, r_{1}, r_{2}$ são escolhidos aleatoriamente, da posição 0 à $N_{p-1}$, a cada mutação, e são diferentes entre si e do vetor atual $i$.

$$
V_{i, g}=X_{r 0, g} * F\left(X_{r 1, g}-X_{r 2, g}\right), \quad j=0,1, \ldots, D-1
$$

Após a mutação, um cruzamento uniforme é aplicado aos vetores de teste gerados na mutação, como descrito na Equação 5.7. A probabilidade de cruzamento $\mathrm{CR}$, determina o número ou fração dos parâmetros utilizados para o processo. Para determinar se um parâmetro (ou variável) será considerado para o cruzamento, um número randômico é 
gerado entre 0 e 1, e comparado à probabilidade de cruzamento $\mathrm{Cr}$. Se $\mathrm{Cr}$ é maior que o número randômico gerado, o parâmetro $\mathrm{v}_{\mathrm{i}, \mathrm{j}, \mathrm{g}}$ é utilizado para compor o vetor de testes, caso contrário, o parâmetro $x_{\mathrm{i}, \mathrm{j}, \mathrm{g}}$ é utilizado. Além disso, o parâmetro jrand, selecionado aleatoriamente para comparação, é excluído do vetor de testes para garantir que o parâmetro $x_{i, g}$ não seja duplicado.

$$
U_{i, g}=u_{j, i, g}= \begin{cases}v_{j, i, g} & \text { Se rand }(0,1) \leq C r \text { or } j=j \text { jrand } \\ x_{i, j, g} & \text { Caso contrário }\end{cases}
$$

O processo de seleção consiste em verificar se o vetor $U_{i, g}$ tem um valor de função objetivo melhor que o vetor $X_{i, g}$, conforme mostra a Equação 5.8 .

$$
X_{i, g}= \begin{cases}U_{i, g} & \text { Se } f\left(U_{i, g}\right) \leq f\left(X_{i, g}\right) \\ X_{i, g} & \text { Caso contrário }\end{cases}
$$

A Figura 5.3 indica o fluxograma geral do algoritmo DE.

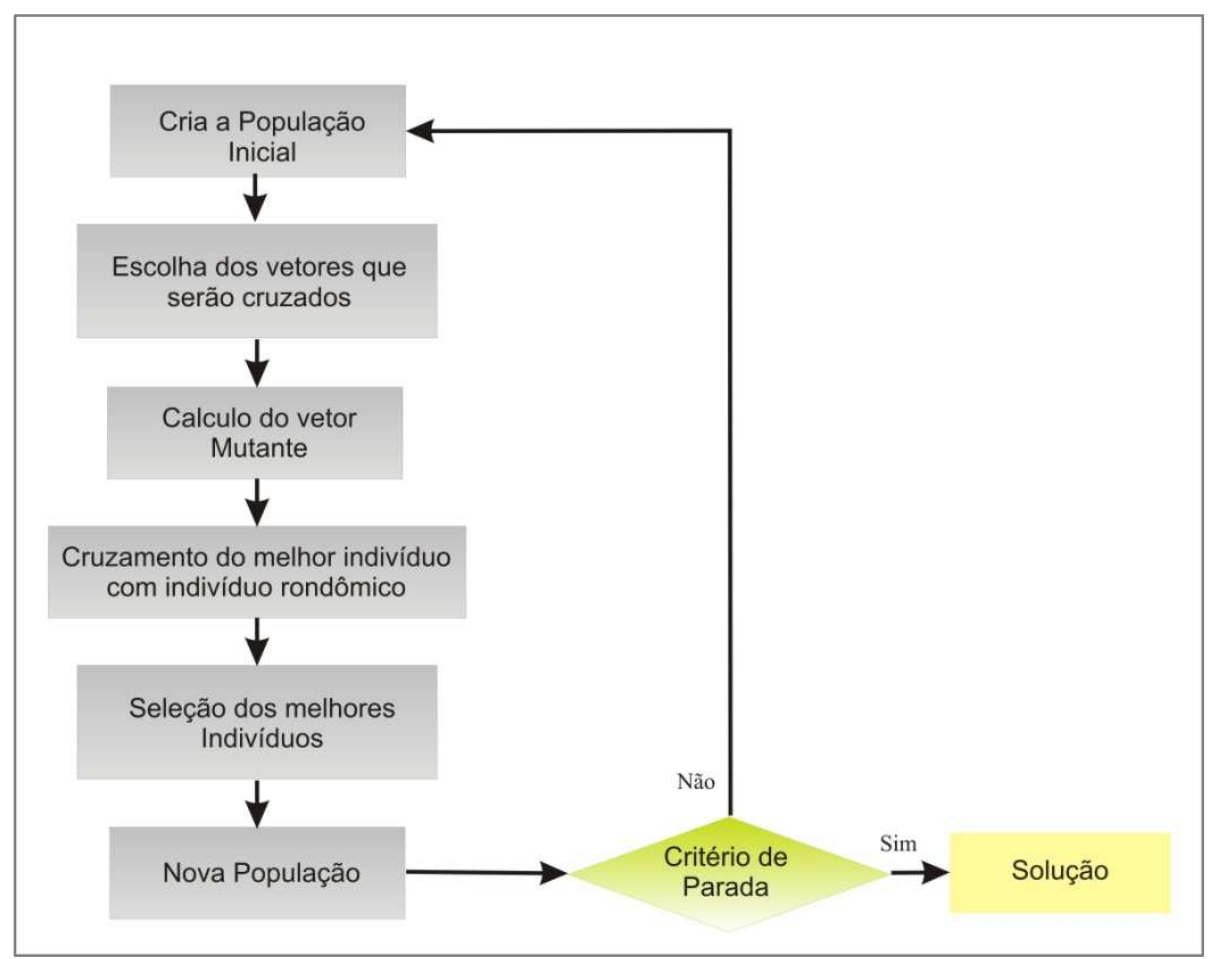

Figura 5.3 - Fluxograma representando o esquema do algoritmo DE

A convenção geral usada por diferentes variantes do $D E$ é $D E / \alpha / \beta / \gamma$, onde $\alpha$ representa o vetor a ser perturbado (selecionado aleatoriamente), $\beta$ o número de vetores considerados para a mutação e y o tipo de cruzamento utilizado (pode ser exp: exponencial ou bin: binomial). 
A estratégia "DE/rand/1/bin", também conhecida como DE clássico, representa a estratégia original proposta por Price \& Storn (1997). Os mesmos autores propuseram outras estratégias, listadas a seguir: DE/best/1/exp; DE/rand/1/exp; DE/rand-to-best/1/exp; DE/best/2/exp; DE/rand/2/exp; DE/best/1/bin; DE/rand/1/bin; DE/rand-to-best/1/bin; $D E /$ best/2/bin; DE/rand/2/bin. Neste trabalho foi utilizada a estratégia de solução $\mathrm{DE} /$ best/1/exp que apresentou bons resultados para os problemas propostos. Mais detalhes relacionados ao algoritmo DE podem ser encontrados em Price \& Storn (1997), Price et al. (2005) e Chakraborty (2008).

Para a estratégia de solução DE/best/1/exp, na Equação 5.6 o valor de $X_{r 0, g}$ equivale ao vetor que possui o melhor valor da função objetivo.

No próximo item desta tese são apresentadas algumas particularidades que devem ser consideradas na construção do modelo e consequentemente avaliadas no processo de otimização. 


\section{SSD PARA OUTORGA DE LANÇAMENTO DE EFLUENTES}

A outorga de direito de uso tem como objetivo assegurar o controle quantitativo e qualitativo dos usos da água e o efetivo exercício dos direitos de acesso à água. Conforme recomenda a Resolução CNRH no 16/2001, para a outorga para lançamento de efluentes, a concessão deve ser analisada em função da quantidade de água necessária para a diluição da carga poluente. Assim sendo, este instrumento deve, além de garantir o atendimento das demandas, garantir a permanência de uma vazão no rio suficiente para diluir os despejos, de tal forma que os limites previstos no enquadramento do curso de água não sejam excedidos.

A outorga tem importante papel no gerenciamento dos recursos hídricos, uma vez que representa um instrumento de comando e controle, quantitativo e qualitativo, proporcionando a distribuição justa e equilibrada desse recurso, assim como a efetiva melhoria dos problemas de poluição hídrica.

A motivação para desenvolvimento deste estudo partiu da carência metodológica observada nos órgãos gestores para a análise do instrumento de outorga, principalmente quando envolve a outorga para lançamento de efluentes, a qual engloba um número maior de particularidades, tais como restrições ambientais, isonomia entre usuários, custos de despoluição hídrica, entre outros.

Esta tese apresenta uma proposta metodológica para auxiliar a aplicação da outorga de efluentes, através da otimização das outorgas visando a maximização dos usos da água, captações e lançamentos, e a minimização dos custos de implementação das medidas de despoluição, através da maximização das vazões de diluição. Estes conceitos foram introduzidos em um Sistema de Suporte à Decisão para a análise da outorga de efluentes.

Os SSDs possuem papel fundamental na gestão de recursos hídricos, pois estes potencializam e agilizam as análises através da interação entre a base de dados e os modelos de simulação e/ou otimização e a análise dos resultados. Esta integração é uma das principais funcionalidade dos SSDs.

No Item 4.2, foram apresentados alguns modelos desenvolvidos que simulam com eficiência a qualidade da água ao longo dos trechos de rio, partindo dos resultados de quantidade obtido do balanço hídrico. Esses modelos auxiliam na análise do processo de outorga, pois permitem que se determine um cenário de quantidade e de qualidade da água a partir dos dados de captações e lançamentos.

Em bacias que não atingiram um estado crítico, ou seja, que existe água em abundância para atender os usos, sejam eles de quantidade (captações) ou de qualidade (vazão de diluição), esses modelos apresentam resultados satisfatórios. O desafio está quando se deseja analisar bacias críticas, onde existem déficits e as vazões existentes no 
corpo hídrico não atendem as necessidades de uso, sejam elas em quantidade ou qualidade. Os déficits podem paralisar o sistema de outorga, sendo necessário aumentar a disponibilidade hídrica, reduzindo as vazões de diluição $Q_{\text {dill }}$, para isto torna-se necessário otimizar a alocação de carga poluente ao longo do corpo receptor, impondo tratamento às cargas efluentes, para que o limite da classe do corpo d'água estabelecida pelo enquadramento não seja excedido.

Os modelos AcquaNet e OutorgaLS, apresentados no Item 4.2, são modelos de rede de fluxo que possuem um algoritmo de otimização, o Out-of-Kilter (Labadie,1988), o qual é eficiente para a análise quantitativa, ou seja, para a outorga de quantidade. A introdução da vazão de diluição $Q_{\text {dil }}$ e a análise de qualidade da água torna a nova função objetivo não linear, o que impossibilita a utilização do algoritmo Out-of-Kilter, uma vez que este otimiza redes de fluxo com funções objetivo lineares.

A Figura 6.1 apresenta o fluxograma de análise da outorga de quantidade e qualidade realizada pelos modelos existentes, os quais não integram no processo de otimização a análise da outorga de efluentes (vazão de diluição).

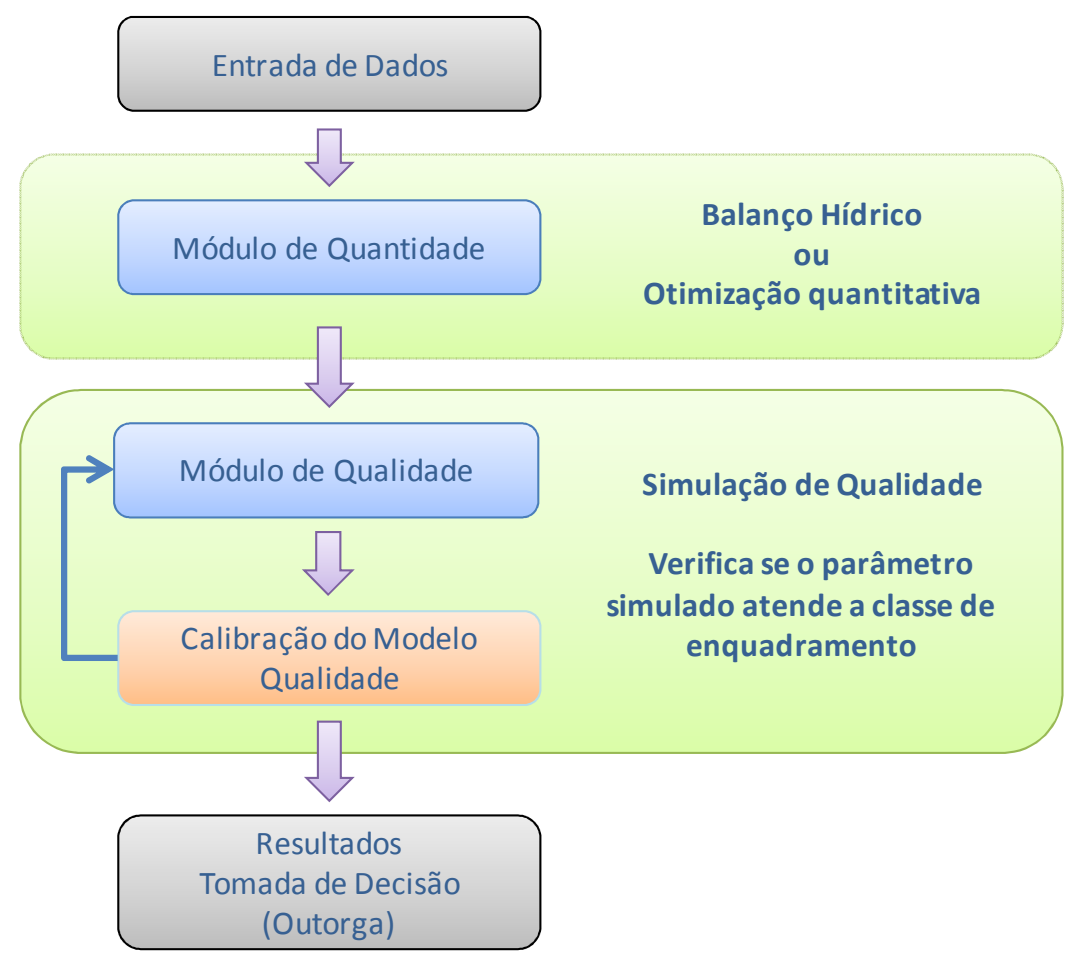

Figura 6.1 - Sistema atual para análise de outorga quantitativa e qualitativa

A tomada de decisão é baseada na verificação do atendimento aos padrões de qualidade estabelecidos pelo enquadramento do corpo receptor.

A otimização integrada de quantidade e qualidade da água necessita a utilização de um algoritmo de otimização capaz de solucionar problemas complexos e com um elevado 
número de restrições. A Figura 6.2 apresenta o fluxograma do processo de análise de outorga, com a utilização de algoritmos evolucionários para avaliar a outorga de efluentes, otimizando a alocação cargas, através da minimização dos custos de tratamento. Este fluxograma representa o processo iterativo para a análise das estratégias de outorga de efluentes proposto por esta tese.

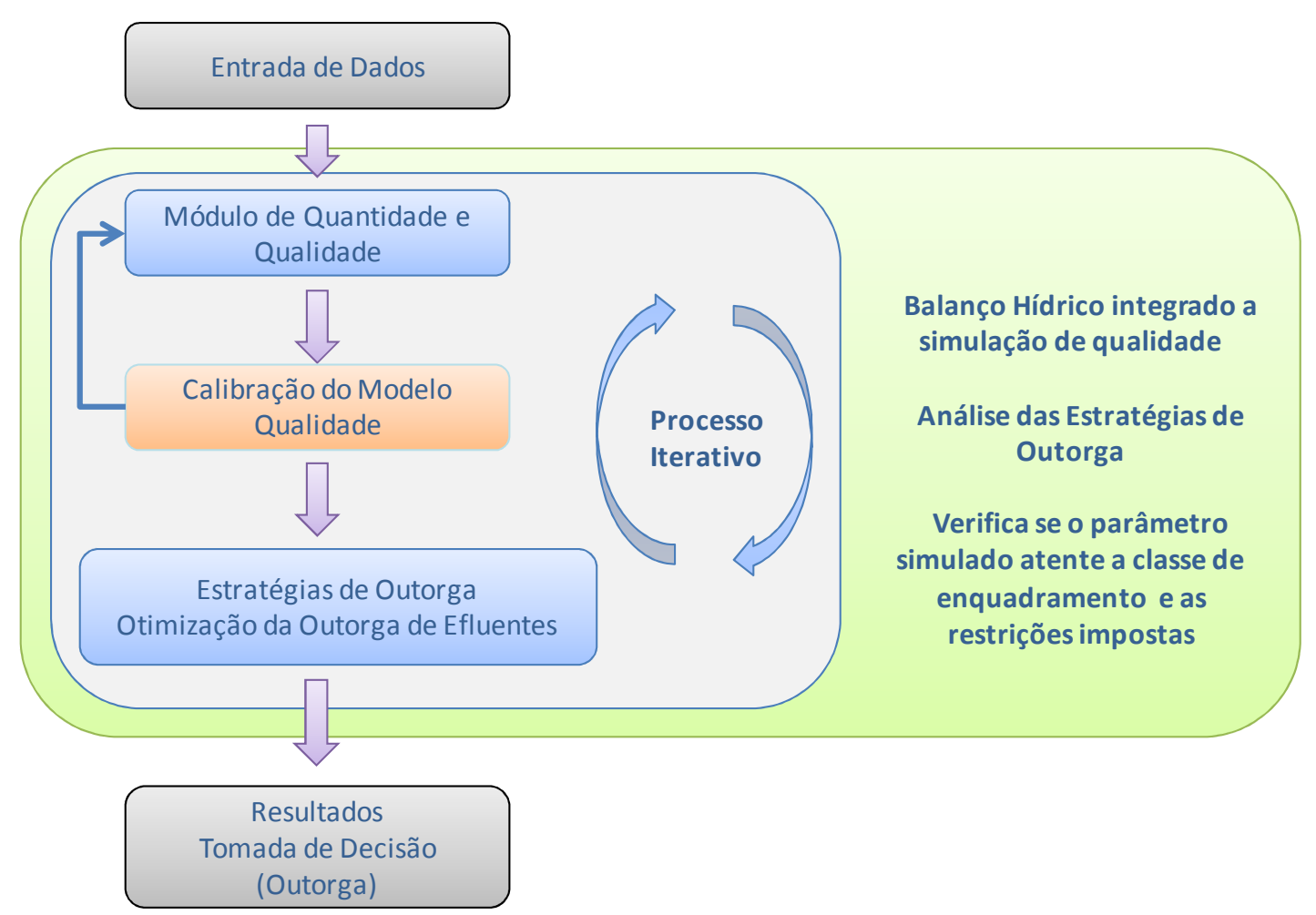

Figura 6.2 - Sistema de Suporte a Decisão proposto para análise de outorga quantitativa e qualitativa

A proposta apresentada neste estudo tem como objetivo otimizar integradamente as demandas de uso e os lançamentos de efluentes, o que permitirá alterar as eficiências de tratamento de efluentes e a quantidade de água destinada as demandas de uso consuntivo, buscando uma maior eficiência do sistema minimizando os custos de tratamento e maximizando os usos quantitativos.

As ferramentas utilizadas atualmente nas análises da outorga não consideram a otimização integrada dos aspectos de qualidade (vazão de diluição) e quantidade para o processo decisório. Desta forma, o SSD proposto nesta tese utiliza técnicas de otimização, algoritmo evolucionários, que permitem esta análise integrada, assim como avaliar as diferentes estratégias de outorga propostas, garantindo maior agilidade na tomada de decisão.

A Figura 6.3 apresenta o fluxograma do SSD proposto para outorga de efluentes. 


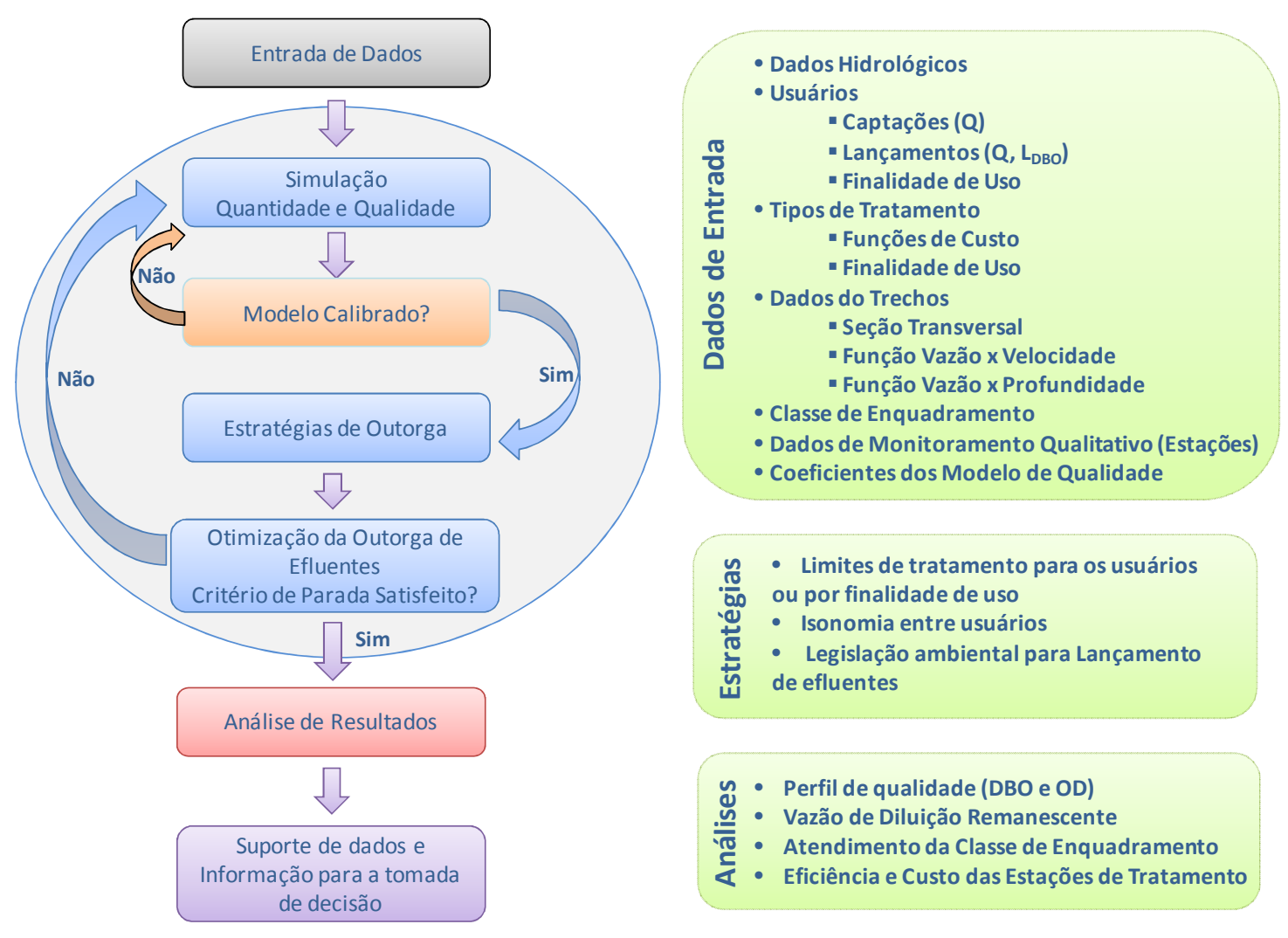

Figura 6.3 - Fluxograma do SSD Outorga de Efluentes

Como parte das estratégias, o SSD permite ao gestor estabelecer limites mínimos e máximos para as eficiências de tratamento de efluente de cada usuário da bacia. Assim obtém-se maior controle sobre os usuários poluidores. Outra forma de impor as restrições é através da adoção de limites agrupados por finalidade de uso, onde os grupos de usuários com mesmo uso estão sujeitos as mesmas restrições, ou seja, mesmas eficiências de tratamento. Este tipo de intervenção permite a flexibilização ou restrição dos níveis de tratamento de forma individual ou coletiva.

Os tipos de tratamento de efluentes, com suas respectivas eficiências de remoção de carga e funções de custo, são dados de entrada para o modelo. O sistema desenvolvido permite o cadastro de diferentes tipos de tratamento de efluentes, os quais ficarão vinculados às finalidades de uso.

Este processo permite ao sistema uma maior flexibilidade, pois admite a entrada de dados de estações de tratamento, eficiência e custo, para cada finalidades de uso específica. As estações de tratamento cadastradas no SSD apresentam características, eficiência e custo, típicas de efluentes domésticos. Por este motivo, foi disponibilizada a alternativa de recadastramento destes valores, tendo em vista o tratamento de efluentes industriais, onde estes valores podem ser distintos em função das características próprias do efluente. 
Entre as estratégias de outorga pré-programadas no SSD estão a análise da Legislação Ambiental e a questão da isonomia entre os usuários. A legislação ambiental de cada Estado pode ser avaliada no SSD, assim, independentemente das alternativas selecionadas o otimizador deve respeitar os limites impostos para o lançamento de efluentes pela Legislação Ambiental, como por exemplo, para o Estado de São Paulo o lançamento de um efluente deve ter uma concentração máxima de $60 \mathrm{mg} / \mathrm{L}$ de DBO ou tratamento superior a $80 \%$ de remoção de carga. Estes limites constituem os dados de entrada do SSD, o que permite que o mesmo seja aplicado em bacias hidrográficas que apresentem diferentes especificações quanto aos limites de lançamento.

A questão da isonomia entre os usuários da bacia é bastante polêmica. O SSD proposto resolve esta situação através da imposição de uma restrição ao algoritmo, a qual considera que os usos de mesma finalidade deve atender aos mesmos níveis de tratamento de seus efluentes. Este tipo de restrição limita o campo de atuação do otimizador, pois as eficiências de tratamento devem ser determinadas para grupos de usuários de mesma finalidade de uso.

Ao considerar a isonomia entre usuários, na análise da outorga de efluentes, deve ser observada a seguinte situação: usuários localizados em regiões mais críticas de qualidade d'água do corpo receptor provocam uma elevação na eficiência de tratamento dos efluentes de todos os usuários de mesma finalidade de uso, tendo em vista o atendimento da classe de enquadramento em todos os trechos do rio. Pois, a isonomia define que os usuários de mesma finalidade de uso devem obedecer as mesmas eficiências de tratamento para seus efluentes, independente da capacidade de assimilação do corpo receptor no trecho onde será realizado o despejo do efluente. Isto eleva o custo global de implantação das estações de tratamento.

A diversidade de estratégias que podem ser analisadas de forma ágil e precisa por um SSD permite a liberdade de avaliarem-se diferentes cenários. Estes cenários alteram as restrições impostas ao algoritmo, permitindo assim flexibilizar a análise ou restringir o espaço de busca. Estas restrições têm como objetivo avaliar situações específicas para cada bacia.

Ao se optar pela isonomia entre os usuários o otimizador buscará a melhor solução para a função objetivo, analisando as descargas de efluentes em grandes grupos, os quais são definidos, agrupados, pela finalidade do uso do efluente. Assim, usuários do mesmo setor produtivo devem ter as mesmas restrições ambientais, independente da localização do uso na bacia e da qualidade ambiental do corpo receptor. Este tipo de análise onera o custo global das medidas de despoluição, pois obriga os usuários localizados em trechos de rio com condições ambientais mais favoráveis aplicar a mesma medida de despoluição do 
usuário localizado em um trecho ambientalmente degradado, onde a capacidade de assimilação da carga poluidora é menor.

Este tipo de análise apresenta vantagens e desvantagens. $O$ aspecto positivo desta alternativa é a melhora do perfil de qualidade da água final no rio. Por outro lado, o custo global das medidas de despoluição torna-se mais elevado, o que pode dificultar sua implementação.

Sob o ponto de vista do usuário do sistema existe uma grande discussão sobre a aplicação da isonomia entre os usos, pois usuários localizados em áreas mais degradas não devem ser penalizados pela condição de degradação do corpo receptor causada pelos demais usos, assim como não se deve atribuir um custo maior a um usuário com mesma finalidade de uso localizado na mesma bacia hidrográfica. A Figura 6.4 apresenta o fluxograma com as estratégias que o SSD disponibiliza para a tomada de decisão.

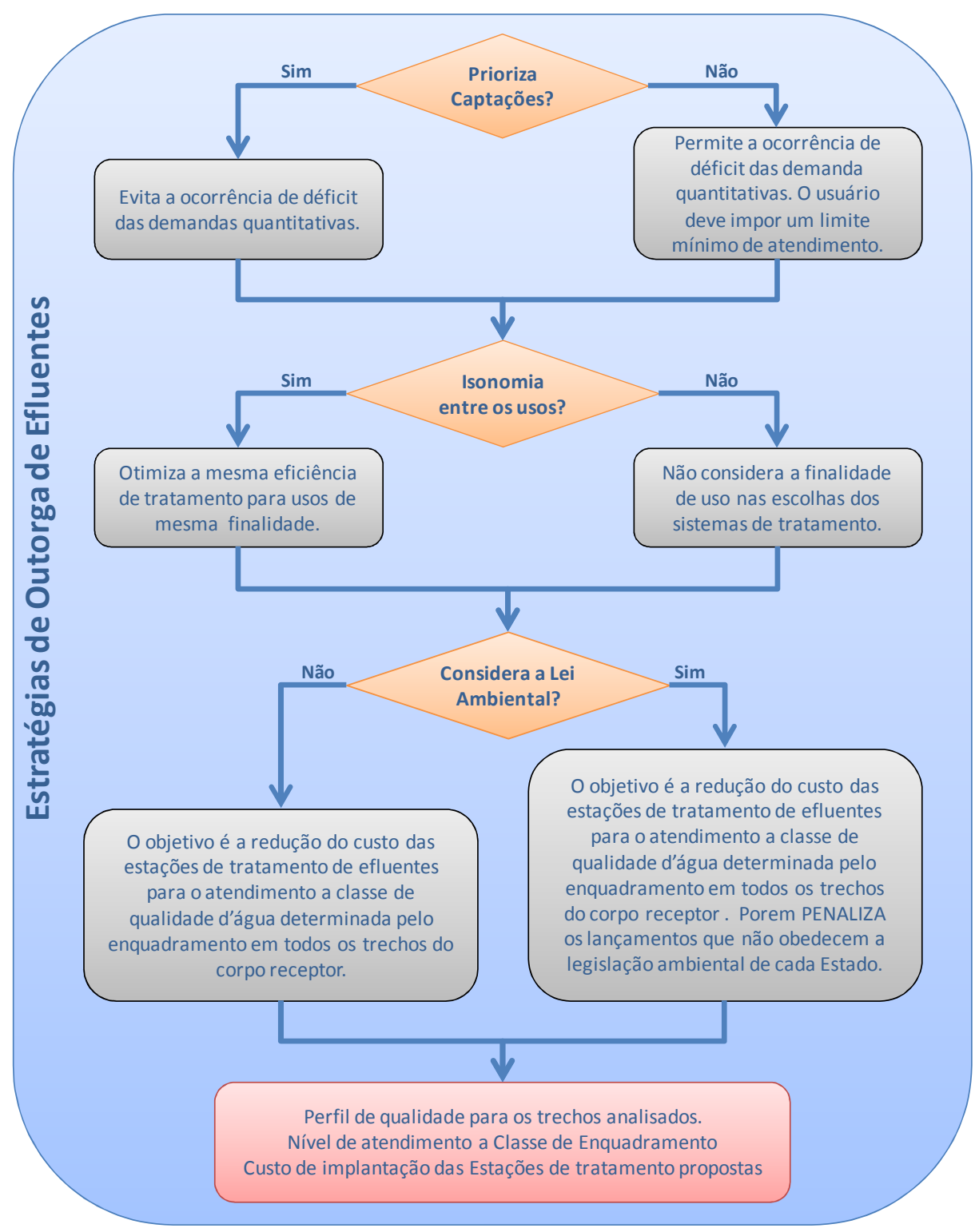

Figura 6.4 - Estratégias para análise de outorga de efluentes presentes no SSD proposto 
O tomador de decisão deverá definir qual estratégia será utilizada no processo de análise, tais como priorizar as captações, utilizar isonomia entre usuários ou ainda considerar as leis ambientais. O SSD possui caráter flexível, pois permite introduzir restrições em pontos localizados do sistema, como por exemplo, restringir para certa finalidade de uso limites diferentes para as eficiências de tratamento, assim como restringir os usuários de forma individualizada.

Os SSDs têm a função de avaliar diferentes estratégias e assim obter respostas e quantificar o impacto de cada alternativa. Os resultados das análises produzidas devem ser avaliados pelo órgão gestor, o qual deve tomar a decisão tendo em vista o bem comum da bacia hidrográfica como um todo, considerando as expectativas dos usuários, assim como as exigências ambientais.

\subsection{Equacionamentos do modelo}

Neste Item são apresentados os equacionamentos que foram introduzidos no SSD proposto, os quais são necessários para representar os fenômenos que ocorrem no corpo hídrico, assim como as equações de custo utilizadas para o estudo de caso desta tese.

\subsubsection{Equações de balanço (quantitativo e qualitativo) e de decaimento de $D B O$ e $O D$}

O balanço quantitativo nos pontos de interesse é calculado através da Equação 6.1. Para o balanço qualitativo foi considerado mistura completa nos pontos de lançamento de carga pontual como mostra a Equação 6.2.

$$
\begin{aligned}
& Q_{\text {Rio. }_{i}}=Q_{\text {Rio.i-1 }}+Q_{\text {Nat } \cdot i}+Q_{\text {Eflu } \cdot i}-D_{\cdot i}
\end{aligned}
$$

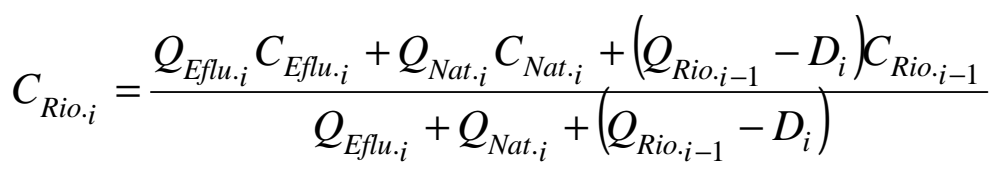

Onde:

$Q_{E f l u}$ e $C_{E f l u}$ representam a vazão e a concentração do efluente, respectivamente;

$Q_{N a t}$ e $C_{N a t}$ representam a vazão e a concentração natural afluente, respectivamente; e

$Q_{\text {Rio }}$ e $C_{\text {Rio }}$ representam a vazão e a concentração do rio, respectivamente. 
O SSD desenvolvido para auxiliar o processo de outorga de efluentes utiliza em sua análise da qualidade da água os parâmetros demanda bioquímica de oxigênio (DBO) e oxigênio dissolvido (OD).

A DBO foi selecionada para inserção no SSD por ser um indicador da presença de matéria orgânica no corpo hídrico e por estar presente na legislação ambiental, assim sendo, sua análise para o processo de outorga de efluentes cumpre as exigências ambientais presentes na legislação.

O OD é um parâmetro que indica as condições ambientais do corpo hídrico. A análise deste parâmetro é fundamental especialmente quando o corpo hídrico está enquadrado em classe 4, para qual a legislação ambiental não estabelece a concentração limite para o parâmetro DBO. No entanto, ao estabelecer o limite mínimo para o oxigênio dissolvido a demanda de oxigênio não deve exceder aos limintes mínimos, uma vez que o consumo de oxigênio para decomposição da matéria orgânica pode levar a déficits de OD.

A demanda bioquímica de oxigênio (DBO) é determinada através da Equação 6.3, a qual representa o decaimento da matéria orgânica no trecho de rio considerado, o comportamento do oxigênio dissolvido no trecho foi obtido a partir da Equação 6.4.

$$
L=L_{0} e^{-\frac{k_{r}}{U} x}+\frac{S_{L}}{k_{r}}\left(1-e^{-\frac{k_{r}}{U} x}\right)
$$

Onde:

$k_{r}$ - representa a taxa total de remoção $\left(\right.$ dia $\left.^{-1}\right)$;

$k_{d}$ - representa a taxa de remoção relacionada a decomposição da matéria orgânica (dia1);

$k_{s}$ - a taxa de remoção relacionada a sedimentação $\left(\right.$ dia $\left.^{-1}\right)$;

$L_{0}$ - representa a concentração de DBO carbonácea inicial $(\mathrm{mg} / \mathrm{L})$;

$U$ - é a velocidade $(\mathrm{m} / \mathrm{s})$;

$x$ - é a distância $(m)$; e

$S L$ - representa a carga difusa de DBO $\left(\mathrm{g} / \mathrm{m}^{3} \mathrm{dia}\right)$.

$$
D=D_{0} e^{-\frac{k_{a}}{U} x}+\frac{k_{d} L_{0}}{k_{a}-k_{r}}\left(e^{-\frac{k_{r}}{U} x}-e^{\frac{k_{a}}{U} x}\right)+\frac{1}{k_{a}}\left(\frac{S_{L} k_{d}}{k_{r}}\right)\left(1-e^{-\frac{k_{a}}{U} x}\right)-\frac{S_{L} k_{d}}{k_{r}\left(k_{a}-k_{r}\right)}\left(e^{-\frac{k_{r}}{U} x}-e^{\frac{-k_{a}}{U} x}\right)
$$

Onde:

$D$ - representa o déficit de oxigênio $(\mathrm{mg} / \mathrm{L})$;

$D_{0}$ - o déficit inicial de oxigênio $(\mathrm{mg} / \mathrm{L}) ; \mathrm{e}$ 
$k_{a}$ - a constante de reaeração $\left(d^{1 a^{-1}}\right)$.

Para que o modelo de simulação reproduza corretamente o perfil do parâmetro analisado, devem ser adotados valores adequados para os coeficientes $k a, k d$ e $k s$. A determinação destes valores pode ser um processo exaustivo, devido ao grande número de combinações possíveis. Este processo é denominado de calibração do modelo.

\subsubsection{Coeficientes dos modelos de qualidade da água na outorga de efluentes}

Calibrar um modelo matemático de qualidade da água é sempre uma tarefa difícil, devido à grande quantidade de variáveis envolvidas no processo, tais como, características físicas, biológicas e químicas do corpo hídrico. Os corpos d'água apresentam características particulares, por isso, é preciso que seja realizada a determinação de constantes de qualidade diferentes para cada corpo hídrico. Estas constantes de qualidade de água devem ser determinadas, dentro de faixas de valores, para representar da melhor forma as características do rio, este processo é denominado de calibração do modelo de qualidade, e é considerado uma etapa fundamental para implementação do modelo de qualidade d'água em um corpo hídrico.

Para que um modelo de qualidade de água possa ser calibrado corretamente, 0 cadastro de usuários do sistema deve ser atualizado e condizente com o período de dados de qualidade d'água das estações de monitoramento. Quando se analisa os parâmetros de DBO e OD os coeficientes a serem calibrados são: $k_{d}=$ taxa de remoção relacionada a decomposição da matéria orgânica no sedimento $\left(\right.$ dia $\left.^{-1}\right), \mathrm{k}_{\mathrm{s}}=$ taxa de remoção relacionada a sedimentação $\left(\right.$ dia $\left.^{-1}\right)$ e $k_{a}=$ taxa de reaeração.

O coeficiente de desoxigenação expressa a taxa de degradação da matéria orgânica no meio aquático. Chapra (1997) apresenta valores típicos do coeficiente de desoxigenação para diferentes níveis de tratamento, conforme mostra a Tabela 6.1.

Tabela 6.1- Valores típicos para a taxa de degradação da matéria orgânica $\left(\mathbf{k}_{\mathrm{d}}\right)$

\begin{tabular}{l|c}
\hline Tratamento & $\mathrm{k}_{\mathrm{d}}\left(\mathrm{dia}^{-1}\right)$ \\
\hline Esgoto Bruto & $0,35(0,20-0,50)$ \\
Tratamento primário & $0,20(0,10-0,30)$ \\
Tratamento secundário & $0,075(0,05-0,10)$ \\
\hline
\end{tabular}

O esgoto bruto ao receber um tipo de tratamento, seja ele primário, secundário ou terciário, o valor da taxa de degradação da matéria orgânica, do trecho de influência deste despejo pode ser alterada, evitando que ocorra alteração no perfil do parâmetro em análise. O comportamento dos parâmetros de qualidade d'água deve ser monitorado ao longo do tempo, avaliando as alterações do cenário de carga e sua influência sobre o perfil do 
parâmetro de qualidade analisado, para isto, torna-se fundamental o monitoramento constante da qualidade da água.

O coeficiente de reareação expressa a taxa de reareação atmosférica do corpo hídrico com o ar atmosférico. A Tabela 6.2 apresenta as equações propostas por Owens-Gibbs, O'Connor-Dobbins e Churchill para a determinação do coeficiente (Chapra, 1997).

Tabela 6.2 - Equações para determinação do coeficiente de reaeração

\begin{tabular}{c|c|c}
\hline Owens-Gibbs & O'Connor-Dobbins & Churchill \\
\hline$k_{a}=5,32 \cdot \frac{U^{0,67}}{H^{1,85}}$ & $k_{a}=3,93 \cdot \frac{U^{0,5}}{H^{1,5}}$ & $k_{a}=5,026 \cdot \frac{U}{H^{1,67}}$ \\
\hline Profundidade $(\mathrm{m}): 0,12-0,73$ & Profundidade $(\mathrm{m}): 0,30-9,14$ & Profundidade $(\mathrm{m}): 0,61-3,35$ \\
Velocidade $(\mathrm{m} / \mathrm{s}): 0,03-0,55$ & Velocidade $(\mathrm{m} / \mathrm{s}): 0,15-0,49$ & Velocidade $(\mathrm{m} / \mathrm{s}): 0,55-1,52$ \\
\hline
\end{tabular}

Uma vez calibrado o modelo de qualidade para um corpo d'água este pode ser utilizado para reproduzir cenários, assim como avaliar o aporte de carga adicional ou a retirada de carga através de medidas de despoluição.

\subsubsection{Vazão de diluição}

A vazão de diluição é a quantidade de água presente do corpo d'água capaz de diluir a concentração de um poluente mantendo os limites do parâmetro de qualidade d'água analisado na classe de enquadramento do corpo receptor. Diversos autores propuseram equações para determinar o valor da vazão de diluição.

A equação proposta por Kelman (1997) e MMA (2000), Equação 6.5, utiliza a concentração natural (concentração de pré-desenvolvimento) como a concentração do rio, este tipo de enfoque apresenta vantagens e desvantagens. Entre as vantagens está que os usuários da bacia possuem as mesmas condições de análise, pois os usuários de montante não interferem no calculo da vazão de diluição dos usuários de jusante. Como desvantagem desta metodologia pode se considerar que ao conceder um limite de outorga de diluição sem avaliar o a influencia dos usuários de montante o perfil de qualidade do corpo d'água pode superar os limites da classe de enquadramento.

$$
\text { Ce.Qe }=\text { Cmax. }(Q e+Q r)-(\text { Cnat. } Q r)
$$

Onde:

$C_{e}$ - concentração do efluente $(\mathrm{mg} / \mathrm{L})$;

$Q_{e}-$ vazão do efluente $\left(\mathrm{m}^{3} / \mathrm{s}\right)$;

$C_{\max }$ - concentração máxima permitida pela classe do rio $(\mathrm{mg} / \mathrm{L})$; 
$Q_{r}$ - vazão no rio $\left(\mathrm{m}^{3} / \mathrm{s}\right) ; \mathrm{e}$

$C_{\text {nat }}$ - concentração natural igual a concentração de pré-desenvolvimento ( $\left.\mathrm{mg} / \mathrm{L}\right)$.

Este tipo de análise aplica-se bem para avaliação do instrumento de cobrança, pois o valor a ser cobrado ao usuário deve ser condizente com o aporte de carga poluidora no corpo receptor, e este não deve ser penalizado pelos usos localizados a montante. No caso das análises do processo de outorga, torna-se essencial avaliar os usuários de forma conjunta e, assim, priorizar os limites impostos pelo enquadramento.

A equação proposta por Hora (2001) é diferente da equação apresentada por Kelman (1997) e MMA (2000), pois considera a concentração de qualidade da água no rio no ponto de lançamento do efluente. Dessa forma, para a determinação da vazão de diluição são considerados todos os lançamentos existentes de montante com suas respectivas cargas, o que possibilita uma análise mais realista do perfil de qualidade, quando comparada com a metodologia que considera apenas a contribuição natural. $\mathrm{A}$ Equação 6.6 representa a metodologia proposta por Hora (2001).

$$
(\text { Ce.Qe })=(\text { Cmax.Qr })-(\text { Cr. Qr })
$$

Equação 6.6

Onde:

$$
\begin{aligned}
& C_{e} \text { - concentração do efluente }(\mathrm{mg} / \mathrm{L}) ; \\
& Q_{e}-\text { vazão do efluente }\left(\mathrm{m}^{3} / \mathrm{s}\right) ; \\
& C_{m a x} \text { - concentração máxima permitida pela classe do rio }(\mathrm{mg} / \mathrm{L}) ; \\
& Q_{r} \text { - vazão no rio }\left(\mathrm{m}^{3} / \mathrm{s}\right) ; \text { e } \\
& C_{r} \text { - concentração no rio }(\mathrm{mg} / \mathrm{L}) .
\end{aligned}
$$

Ao se considerar a interferência de todos os usurários na qualidade da água para determinação da vazão de diluição, o método torna-se mais restritivo, pois será necessário um volume maior de água para diluir a mesma carga de efluente do que quando considerada apenas a concentração natural do rio.

Ao avaliar a outorga de diluição desta forma, o otimizador pode impor tratamentos em locais onde existe elevada disponibilidade hídrica para diluição, visando assegurar água para diluir efluentes em regiões mais críticas da bacia, com o objetivo de reduzir os custos globais das medidas de despoluição. O instrumento de cobrança deve estar integrado na análise e, além de incentivar e promover o uso racional da água, deve corrigir ou reparar as injustiças impostas pelo sistema de outorga de efluentes. Assim, usuários que se sentirem injustiçados pela baixa capacidade de diluição do rio no seu ponto de lançamento, o que 
impõe maiores níveis de tratamento, podem ser compensados pelo instrumento de cobrança.

Uma vez que a outorga de direito de uso é um instrumento de comando e controle, cabe a este determinar e estabelecer os limites de uso da água para atender aos usos prioritários e, assim como a obtenção das metas previstas pelo enquadramento dos corpos hídricos.

Os instrumentos de gestão de recursos hídricos devem trabalhar de forma integrada para promover a harmonia entre os usuários da água na bacia hidrográfica, assim como a manutenção da qualidade dos ecossistemas.

\subsubsection{Funções de custos para tratamento de efluentes}

As funções de custos de implantação dos sistemas de tratamento foram apresentadas no item 3.2.5 desta tese. A Tabela 6.3 apresenta as funções de custo em função da vazão a ser tratada, em metros cúbicos por segundo $\left(\mathrm{m}^{3} / \mathrm{s}\right)$, e a respectiva eficiência média de remoção de carga para cada sistema tratamento.

Tabela 6.3- Funções de custos de implantação dos sistemas de tratamento de esgoto (Fonte: Adaptado de Brites, 2010)

\begin{tabular}{|c|c|c|}
\hline Tipo de Tratamento & $\begin{array}{c}\text { Função Custo } 10^{3} \\
\mathrm{R} \$ /\left(\mathrm{m}^{3} / \mathrm{s}\right)\end{array}$ & $\begin{array}{c}\text { Eficiência de Remoção } \\
\text { de DBO }\end{array}$ \\
\hline Tratamento primário avançado & $\mathrm{y}=16906 \mathrm{x}^{0,92}$ & $45 \%$ \\
\hline Reator UASB & $\mathrm{y}=31798 \mathrm{x}^{0,94}$ & $60 \%$ \\
\hline Lagoa Anaeróbia + Lagoa Facultativa & $\mathrm{y}=23661 \mathrm{x}^{0,99}$ & $75 \%$ \\
\hline Reator UASB + Lodo Ativado & $\mathrm{y}=31106 \mathrm{x}^{0,902}$ & $83 \%$ \\
\hline Lodo Ativado por Aeração Prolongada & $\mathrm{y}=39448 \mathrm{x}^{0,92}$ & $90 \%$ \\
\hline Lodo Ativado + Filtração Terciária & $\mathrm{y}=131322 \mathrm{x}^{1,001}$ & $93 \%$ \\
\hline Lodo ativado batelada & $\mathrm{y}=282984 \mathrm{x}^{1,10}$ & $95 \%$ \\
\hline
\end{tabular}

$y$ - custo da medida de despoluição $(R \$)$;

$x$ - vazão a ser tratada $\left(\mathrm{m}^{3} / \mathrm{s}\right)$.

A seguir será apresentada a função objetivo, as restrições e as penalidades impostas para aos algoritmos para a solução dos problemas propostos: calibração automática dos parâmetros de qualidade de água e para a solução das estratégias de outorga estabelecidas para a bacia.

\subsection{Algoritmos de otimização aplicados ao processo de outorga de $\mathbf{R H}$}

Os modelos de qualidade d'água vêm sendo cada vez mais utilizados na gestão de recursos hídricos. A modelagem da qualidade permite avaliar o perfil da qualidade da água 
ao longo do corpo hídrico, e, desta forma, verificar os impactos causados pelo uso da água, estabelecer cenários de controle de carga poluente e alocação de efluentes.

No decorrer desta pesquisa foram estudados diferentes técnicas de otimização para a solução dos problemas propostos. Os algoritmos evolutivos mostraram-se aptos para serem aplicados nesta pesquisa, permitindo um maior grau de liberdade para a implementação de problemas complexos. Entre os algoritmos evolutivos os Algoritmos Genéticos (AG), Particle Swarm Optimization (PSO) e o Differential Evolution (DE) foram escolhidos para a implementação neste problema.

Os algoritmos mencionados permitem maior flexibilidade para a estruturação do problema, sendo capaz de resolver funções objetivo complexas com elevado número de restrições ou penalidades. O estudo da função objetivo, que os algoritmos devem resolver na busca da solução global do problema, é uma tarefa delicada e deve ser exaustivamente testada. Os algoritmos foram implementados no modelo, onde seu código foi construído em linguagem de programação VB.Net.

\subsubsection{Algoritmos de otimização para a calibração de modelos de qualidade da água}

Dentro do processo de modelagem matemática da qualidade da água a calibração do modelo representa uma etapa importante, a qual será responsável pela obtenção de bons resultados.

A calibração é o processo onde os valores dos parâmetros do modelo são identificados de maneira que forneçam o melhor ajuste entre as concentrações simuladas e as observadas. Uma vez estabelecidos, estes parâmetros possibilitam analisar cenários de carga distintos e, desta forma, avaliar os possíveis impactos gerados em função de modificações de usos na bacia hidrográfica.

A calibração dos modelos de qualidade d'água é um processo árduo, pois o ajuste dos parâmetros é um processo interativo, existindo diversas soluções possíveis. Em bacias complexas, com grande número de trechos de rio a serem calibrados, o número de parâmetros torna-se elevado, dificultando ou até mesmo impossibilitando a calibração manual. Para auxiliar nesse processo os algoritmos de otimização vêm sendo utilizados de forma satisfatória.

Tendo em vista esta importante etapa na modelagem matemática, esta pesquisa buscou avaliar o comportamento e o desempenho dos Algoritmos Genéticos (AG), do Particle Swarm Optimization (PSO) e do Differential Evolution (DE) na calibração automática dos coeficientes de reaeração $(k a)$, decomposição da matéria orgânica $(k d)$ e de remoção de matéria orgânica devido ao efeito da sedimentação $(\mathrm{ks})$ para a simulação dos parâmetros de qualidade da água oxigênio dissolvido (OD) e demanda bioquímica de oxigênio (DBO). 
Os algoritmos de otimização (AG, PSO e DE) foram testados com finalidade de minimizar a função objetivo. Esta função objetivo é a soma quadrática das diferenças entre os valores observados e os calculados pelo modelo, onde o critério de parada adotado, neste estudo, foi o número máximo de gerações, o qual deve ser imposto pelo usuário do SSD. A Equação 6.7 apresenta a função objetivo a ser otimizada neste estudo.

$$
f=\min \sum_{i=1}^{N} w_{O D} \cdot\left(O D_{i}{ }_{i} O D_{i}\right)^{2}+w_{D B O} \cdot\left(D B O_{i}^{*}-D B O_{i}\right)^{2}
$$

Onde:

$D B O *(i)$ - representa a concentração observada de $D B O$;

$D B O(i)$ - a concentração calculada de $D B O$;

$O D *(i)$ - a concentração observada de $O D$;

$O D(i)$ - a concentração calculada de $O D$;

$w_{O D}$ - o peso do parâmetro $O D$;

$w_{D B O}$ - o peso do parâmetro $D B O\left(w_{D B O}=1-w_{O D}\right)$;

$N$ - o número de pontos de monitoramento.

$i$ - trechos do curso d'água.

Como restrição do processo de otimização foi imposto que as variáveis decisórias, coeficientes de reaeração $(k a)$, decomposição da matéria orgânica $(k d)$ e de remoção de matéria orgânica devido ao efeito da sedimentação $(k s)$ devem permanecer entre os limites indicado de pelo decisor, como dado de entrada do modelo. A Equação 6.8 a Equação 6.10 apresentam as restrições impostas à otimização da calibração automática dos parâmetros de qualidade da água.

$$
\begin{aligned}
& k_{\mathrm{a} \min (i)} \leq k_{a(i)} \leq k_{\mathrm{a} \max (i)} \\
& k_{\mathrm{d} \min (i)} \leq k_{d(i)} \leq k_{\mathrm{d} \max (i)} \\
& k_{\mathrm{S} \min (i)} \leq k_{S(i)} \leq k_{\mathrm{S} \max (i)}
\end{aligned}
$$

Equação 6.8

Equação 6.9

Equação 6.10

\subsubsection{Algoritmos de otimização aplicado as Estratégias de Outorga de Efluentes}

A utilização de algoritmos de otimização para a outorga de efluentes não é um processo simples, pois são inseridos na análise diversos aspectos integrados, diferente de quando se deseja otimizar apenas as demandas quantitativas, onde se maximiza o 
atendimento das demandas requeridas, problema resolvido hoje com eficiência por sistemas como o AcquaNet (LabSid-USP).

No processo de otimização da outorga de efluentes, as estratégias de outorga devem ser avaliadas cuidadosamente, tendo em vista a maximização dos usos e a redução dos impactos causados pelo lançamento de efluente no corpo hídrico, assim como a minimização dos custos das medidas de despoluição adotadas.

Os algoritmos evolutivos AG, PSO e DE foram avaliados para a solução do problema de alocação de carga no processo de outorga de efluentes (vazão de diluição) e minimização dos custos de implementação das medidas de despoluição.

Os algoritmos evolutivos inseridos no SSD, para auxiliar a tomada de decisão nas questões relacionadas à concessão de outorga de efluentes, foram escolhidos devido à facilidade de implementação e ao seu caráter adaptativo para a solução de problemas complexos. Este caráter flexível é fundamental para o processo de outorga, uma vez que as questões metodológicas encontram-se em contínua evolução e ainda não estão sistematizadas pelos órgãos gestores.

Os algoritmos evolutivos permitem a introdução de restrições e penalidades de forma bastante simplificada, o que facilita o desenvolvimento do SSD para avaliar diferentes estratégias. Esta tese buscou estudar algumas questões metodológicas para a efetivação da outorga de efluentes, assim com avaliar o desempenho dos diferentes algoritmos evolucionários.

A Figura 6.5 apresenta o fluxograma do SSD para a solução do problema proposto para outorga de efluentes. Neste fluxograma pode-se observar os procedimentos a serem adotados para a obtenção dos resultados otimizados, através do algoritmo selecionado pelo decisor. Para o entendimento do fluxograma torna-se importante ressaltar que o número de gerações "N" é um parâmetro dos algoritmos de otimização e representa ciclo executado pelo algoritmo para gerar uma nova população, onde cada geração é representada pela letra " $n$ ". O número de gerações "N" depende da complexidade do problema proposto e deve ser determinado experimentalmente. O número de Trechos "I" está relacionado com a discretização da bacia hidrográfica, onde para cada trecho " $i$ " é possível atribuir as características hidráulicas do escoamento do rio assim como inserir vazões incrementais e as informações dos usuários como captações e lançamentos. 


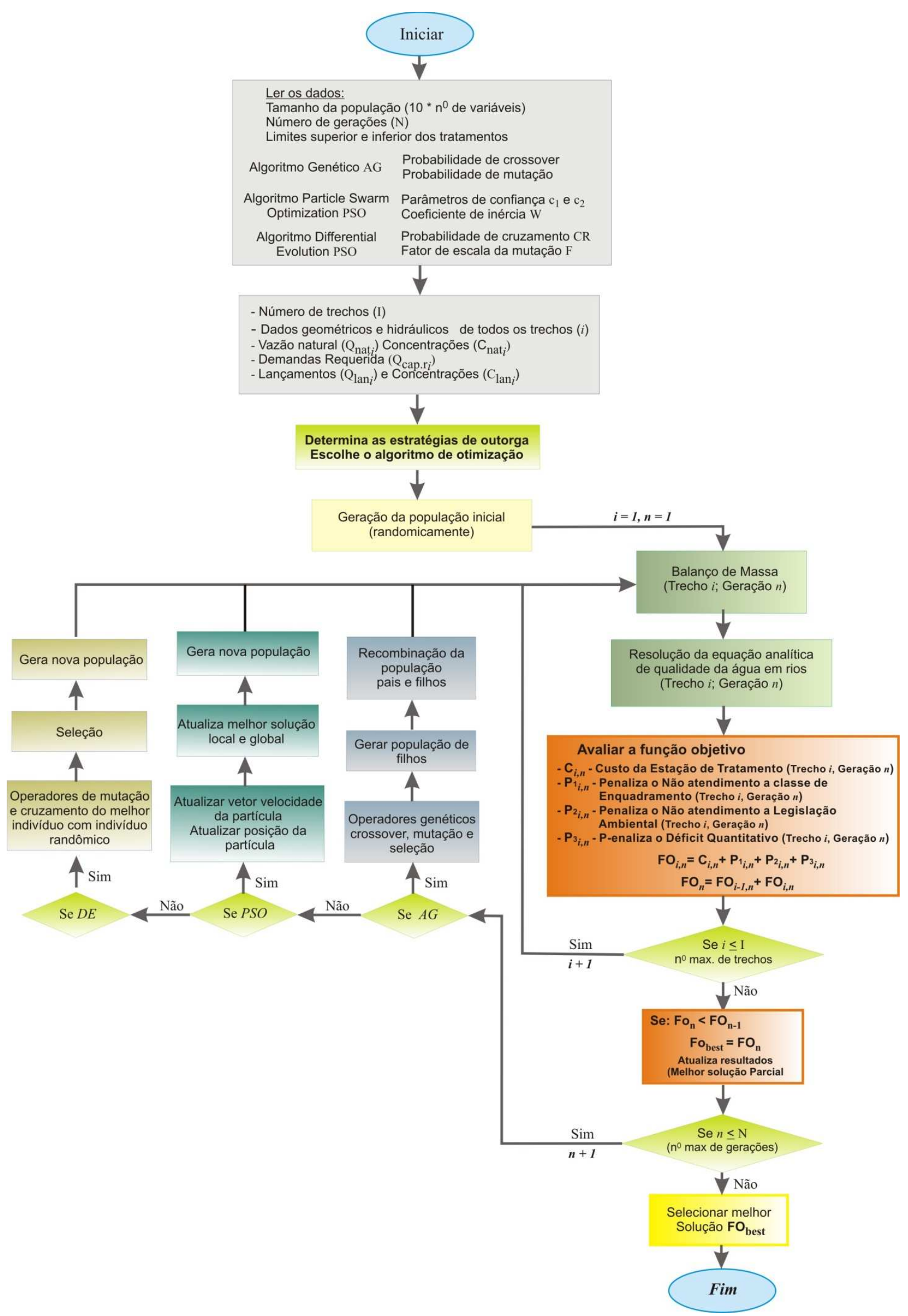

Figura 6.5-Fluxograma do SSD para otimização da outorga de efluentes 
Para a otimização da alocação de carga em um curso d'água, com o objetivo do menor custo de implantação das estações de tratamento de efluentes, a função objetivo proposta visa minimizar o custo das estações de tratamento ao longo do curso da água e maximizar as demandas de uso quantitativo (captações), mantendo o parâmetro de qualidade da água analisado dentro dos limites da classe de enquadramento.

Assim, as variáveis do modelo são as eficiências de tratamento de efluentes as quais estão vinculadas com as funções de custo de implementação da estação, e as demandas consuntivas.

As demandas consuntivas somente serão variáveis do modelo quando forem permitidos déficits na seleção das estratégias de outorga, assim sendo, a demanda passa a ser uma variável a ser otimizada, caso contrário a demanda será igual ao valor da demanda requerida pelo usuário, desde que exista vazão disponível no sistema.

A Equação 6.11 apresenta o somatório do custo de implementação das estações de tratamento que devem ser construídas para cada lançamento de efluentes. Na Tabela 6.3 foram apresentadas as funções de custo utilizadas neste estudo. Estes valores devem ser aperfeiçoados com a o acréscimo de outras informações obtidas em obras reais, da mesma forma devem ser acrescentados os custos de operação das estações de tratamento.

$$
\text { Custo }=\sum_{i=1}^{N} \text { CustoTrat }_{i}
$$

Onde:

CustoTrat $_{i}$ - custo da estação de tratamento do efluente $(i)$;

$N$ - número de trechos analisados;

$i$ - trechos do curso d'água.

Em função das estratégias de outorga escolhidas, podem ser aplicadas até três penalidades na função objetivo.

A primeira penalidade se aplica quando os valores dos parâmetros analisados, DBO e OD, superam os limites da classe de enquadramento. O valor de OD pode ser desconsiderado do cálculo da penalidade sendo esta avaliada apenas em função da DBO. A penalidade 1 pode ser vista na Equação 6.12.

$$
\text { Penalidade }_{1}=\sum_{i}^{N}\left(D B O_{\text {rio } i}-D B O_{\text {classe } i}\right)^{2} W_{q}+\sum_{i}^{N}\left(O D_{\text {rio } i}-O D_{\text {classe } i}\right)^{2} W_{q}
$$

Onde: 
$D B O_{\text {rio } ~}$ - concentração de Demanda Bioquímica de Oxigênio do corpo d'água no trecho $(i)$;

$D B O_{\text {classe } i}$ - limite da classe de enquadramento do parâmetro de Demanda Bioquímica do corpo d'água no trecho $(i)$;

$O D_{\text {rio }}$ - concentração de Oxigênio Dissolvido do corpo d'água no trecho $(i)$;

$O D_{\text {classe }}$ - limite da classe de enquadramento do parâmetro de Oxigênio Dissolvido do corpo d'água no trecho $(i)$;

$N$ - número de trechos analisados;

$i$ - trechos do curso d'água;

$W_{q}$ - Peso aplicado a penalidade para o atendimento a classe de enquadramento do corpo d'água.

O valor do peso da penalidade para o atendimento a classe de enquadramento do corpo d'água $\left(\mathrm{W}_{\mathrm{q}}\right)$ deve ser alto, caso não sejam desejadas as violações ao enquadramento e nenhum trecho do rio. $\mathrm{O}$ valor adotado para $\mathrm{W}_{\mathrm{q}}$ foi de $10^{9}$ para o estudo de caso apresentado a seguir. Este valor deve ser ajustado para cada estudo de caso.

A segunda penalidade aplica-se quando se deseja avaliar, no processo de otimização, a estratégia de outorga referente ao lançamento de efluentes. Esta estratégia impõe penalidades quando um efluente não respeita os limites máximos de despejo, no caso do Estado de São Paulo os efluentes devem respeitar os limites de $60 \mathrm{mg} / \mathrm{L}$ de DBO como concentração máxima para o efluente ou tratamento mínimo de $80 \%$ de eficiência de remoção de carga. A penalidade 2 pode ser vista na Equação 6.13.

$$
\text { Penalidade }_{2}=\sum_{i}^{N}\left(D B O_{\text {efluente } i}-D B O_{\text {RestriçãoAmbiental }}\right)^{2} \cdot W_{A m b}
$$

Onde:

$D B O_{\text {efluente } i}$ - concentração de Demanda Bioquímica de Oxigênio do efluente no trecho $(i)$; $D B O_{\text {RestriçãoAmbiental }}$ - limite máximo de concentração de Demanda Bioquímica de Oxigênio que pode ser lançada no corpo receptor segundo a legislação ambiental;

$N$ - número de trechos analisados;

$i$ - trechos do curso d'água;

$W_{A m b}$ - Peso aplicado a penalidade de restrição ambiental.

O valor do peso da penalidade de restrição ambiental $\left(\mathrm{W}_{\mathrm{Amb}}\right)$ deve ser alto, caso não sejam desejadas as violações dos limites ambientais para o lançamento de efluentes em 
nenhum trecho do rio. $\mathrm{O}$ valor adotado para $\mathrm{W}_{\mathrm{Amb}}$ foi de $10^{9}$ para o estudo de caso apresentado a seguir. Este valor deve ser ajustado para cada aplicação do modelo.

A terceira penalidade está relacionada ao não atendimento das demandas de uso requeridas pelos usuários, assim, sempre que um usuário não for atendido em sua plenitude existe uma penalização na função objetivo, Equação 6.14. Esta penalidade é aplicada quando forem permitidos déficits de demanda na seleção das estratégias de outorga.

$$
\text { Penalidade }_{3}=\sum_{i}^{N}\left(\text { Dem }_{\text {req } i}-\text { Dem }_{\text {otim } i}\right)^{2} \cdot w_{\text {dem }}
$$

Onde:

$D_{\text {Dem }}$ req - Demanda quantitativa requerida pelo usuário no trecho $(i)$;

Dem $_{\text {otim } i}$ - Demanda otimizada pelo algoritmo para o usuário (vazão disponibilizada para captação) no trecho $(i)$;

$N$ - número de trechos analisados;

$i$ - trechos do curso d'água;

$W_{\text {dem }}$ - Peso aplicado à penalidade.

O valor do peso para o atendimento da demanda $\left(W_{d e m}\right)$ é um valor de entrada do modelo. $O$ valor do peso para o atendimento das demandas consuntivas não necessita ser muito elevado, pois o modelo permite aos usuários estabelecer o limite mínimo e máximo de atendimento as demandas. $O$ valor adotado para $W_{\text {dem }}$ no estudo de casa apresentado a seguir é igual a $10^{3}$.

Como restrição para o processo de otimização foi imposto que a variável decisória Eficiência de Tratamento (Eft) deve permanecer entre os limites impostos nos dados de entrada do modelo, Equação 6.15.

$$
E f t_{\min (i)} \leq E f t_{(i)} \leq E f t_{\max (i)}
$$

Onde:

$E f t_{\text {min }}$ - Eficiência de tratamento mínima imposta pelo gestor para o efluente $i$;

$E f t$ - Eficiência de tratamento otimizada pelo algoritmo para o efluente $i$;

$E f t_{\text {Max }}$ - Eficiência de tratamento máxima imposta pelo gestor para o efluente $i$;

$i$ - trechos do curso d'água.

Ao permitir déficit de demanda, assume-se restrições a variável decisória de demanda $\left(\right.$ Dem $\left._{\text {otim }}\right)$ que deve permanecer entre os limites impostos, pelo gestor, como dado de entrada do modelo, Equação 6.6. 


$$
\operatorname{Dem}_{\text {otim min }(i)} \leq \text { Dem }_{\text {otim }(i)} \leq \text { Dem }_{\text {otim max }(i)}
$$

Onde:

$D_{\text {Dem }}^{\text {otim min }}$ - Demanda mínima imposta pelo gestor para a captação $i$

Este valor depende do risco de não atendimento a essa demanda adotou se como:

Risco baixo $90 \%$ de atendimento mínimo da demanda requerida

Risco média $80 \%$ de atendimento mínimo da demanda requerida;

Risco alto $50 \%$ de atendimento mínimo da demanda requerida;

$D_{\text {Dem }}$ otim - Demanda otimizada pelo algoritmo para a captação $i$;

$D_{\text {Dem }}$ otim Max - Demanda máxima imposta pelo gestor para a captação $i$ (Demanda requerida); $i$ trechos do curso d'água.

No estudo de caso apresentado nesta tese adotou-se como Dem $_{\text {otim min }}$ um riso médio de atendimento o que representa um atendimento mínimo de $80 \%$ da demanda requerida pelo usuário.

A Equação 6.17 apresenta a função objeto a ser solucionada pelos algoritmos na análise da outorga de efluentes.

$F O=\min \sum_{i=1}^{N}$ CustoTrat $_{i}+$ Penalidade $_{1 i}+$ Penalidade $_{2 i}+$ Penalidade $_{3 i}$

Equação 6.17

Onde:

CustoTrat $_{i}$ - Custo da implantação do sistema de tratamento no trecho $(i)$;

Penalidade $_{1 i}$. Penalidade devido a não obediência dos parâmetros DBO e OD a classe de enquadramento no trecho $(i)$;

Penalidade $_{2 i}$ - Penalidade devido a não obediência da Legislação Ambiental para lançamento de efluentes no trecho $(i)$;

Penalidade ${ }_{3 i}$. Penalidade devido ao não atendimento a demanda quantitativa requerida pelo usuário no trecho $(i)$;

$N$ número de trechos analisados;

$i$ trechos do curso d'água.

As mesmas funções de balanço quantitativo e soluções analíticas de decaimento dos parâmetros de qualidade da água foram aplicadas para os três algoritmos evolutivos analisados nesta tese.

No capítulo seguinte é apresentado um estudo de caso para o Rio Atibaia/SP. Neste estudo de caso, são avaliados dois parâmetros de qualidade da água DBO e OD. Para estes parâmetros, foram avaliadas as possíveis estratégias de outorga que fazem parte do SSD. A primeira aplicação se refere à calibração automática do modelo de qualidade para os 
parâmetros analisados. A segunda aplicação refere-se à avaliação da outorga de efluentes visando o menor custo de implantação das unidades de tratamento de efluentes para a manutenção dos limites máximos para os parâmetros de qualidade permitidos pela classe de enquadramento, considerando as restrições e penalidades impostas por cada estratégia de outorga analisada. 


\section{SSD APLICADO NA BACIA DO RIO ATIBAIA}

Para avaliar os resultados obtidos com o SSD desenvolvido, assim como as estratégias de outorga de efluentes propostas por esta tese foi realizado um estudo de caso na Bacia Hidrográfica do Rio Atibaia no Estado de São Paulo.

O Rio Atibaia é um importante afluente do Rio Piracicaba, os quais pertencem à UGRHI 05 - Piracicaba, Capivari, Jundiaí. Na Figura 7.1 pode ser observado um mapa com a localização da Bacia Hidrográfica do Rio Atibaia.

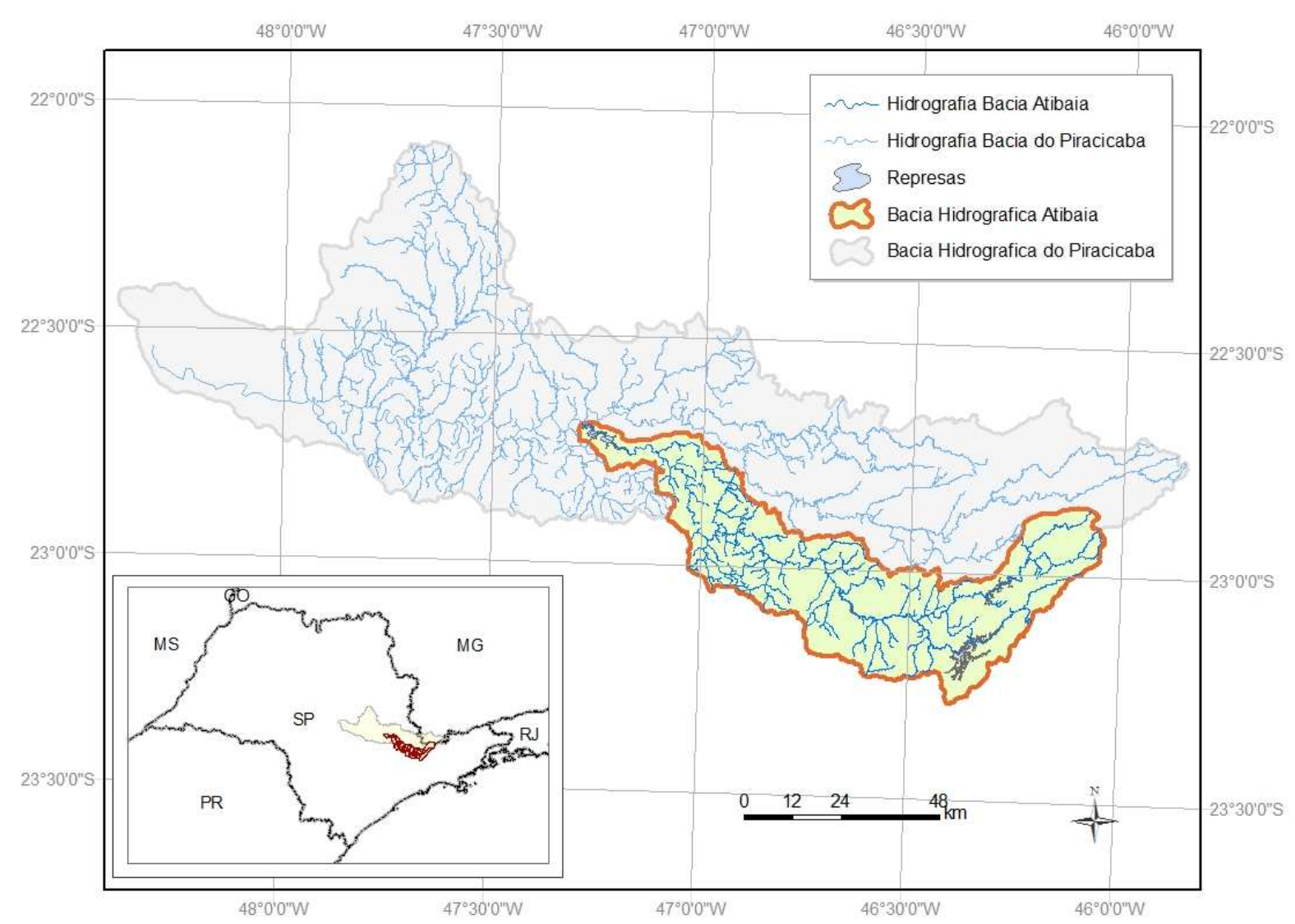

Figura 7.1 - Localização da Bacia Hidrográfica do Rio Atibaia

O Rio Atibaia foi escolhido para esta análise por se tratar de um rio de localização estratégia no estado de São Paulo. Outro ponto que levou a escolha deste estudo de caso foi a existência do cadastro de usuários (outorgas) com informações de cargas efluentes e a finalidade de uso de cada outorga. A qualidade da água do Rio Atibaia é afetada pelos diversos usos registrados na bacia hidrográfica.

A existência do cadastro de usuários foi o ponto decisivo para a escolha deste estudo de caso, pois o SSD proposto permite determinar estratégias distintas para cada finalidade de uso, o que permite avaliar a potencialidade de uso da ferramenta desenvolvida. 
No cadastro de usuários foram verificados as finalidades de uso doméstico (captações e efluentes provenientes de redes coletoras de cidades), industrial (captações e efluentes de indústrias) e agrícola (captações), o cadastro não possuía informação quando aos efluentes (retornos) do uso agrícola, assim como não foi considerada a poluição difusa.

A bacia do Rio Atibaia tem área de $2.827 \mathrm{~km}^{2}$ e a extensão do rio simulado foi de 182 $\mathrm{km}$, que compreende a extensão deste o trecho de jusante dos reservatórios do Sistema Cantareira e o exutório junto ao Rio Piracicaba.

O Rio Atibaia foi divido em 54 trechos, onde cada trecho está vinculado a uma subbacia. A discretização da bacia hidrográfica foi determinada buscando representar da melhor forma possível as características físicas da bacia, assim como, a distribuição dos usos no Rio Atibaia. A Figura 7.2 apresenta a discretização da bacia hidrográfica do Rio Atibaia utilizada neste estudo, assim como, a localização das estações de monitoramento de qualidade da água.

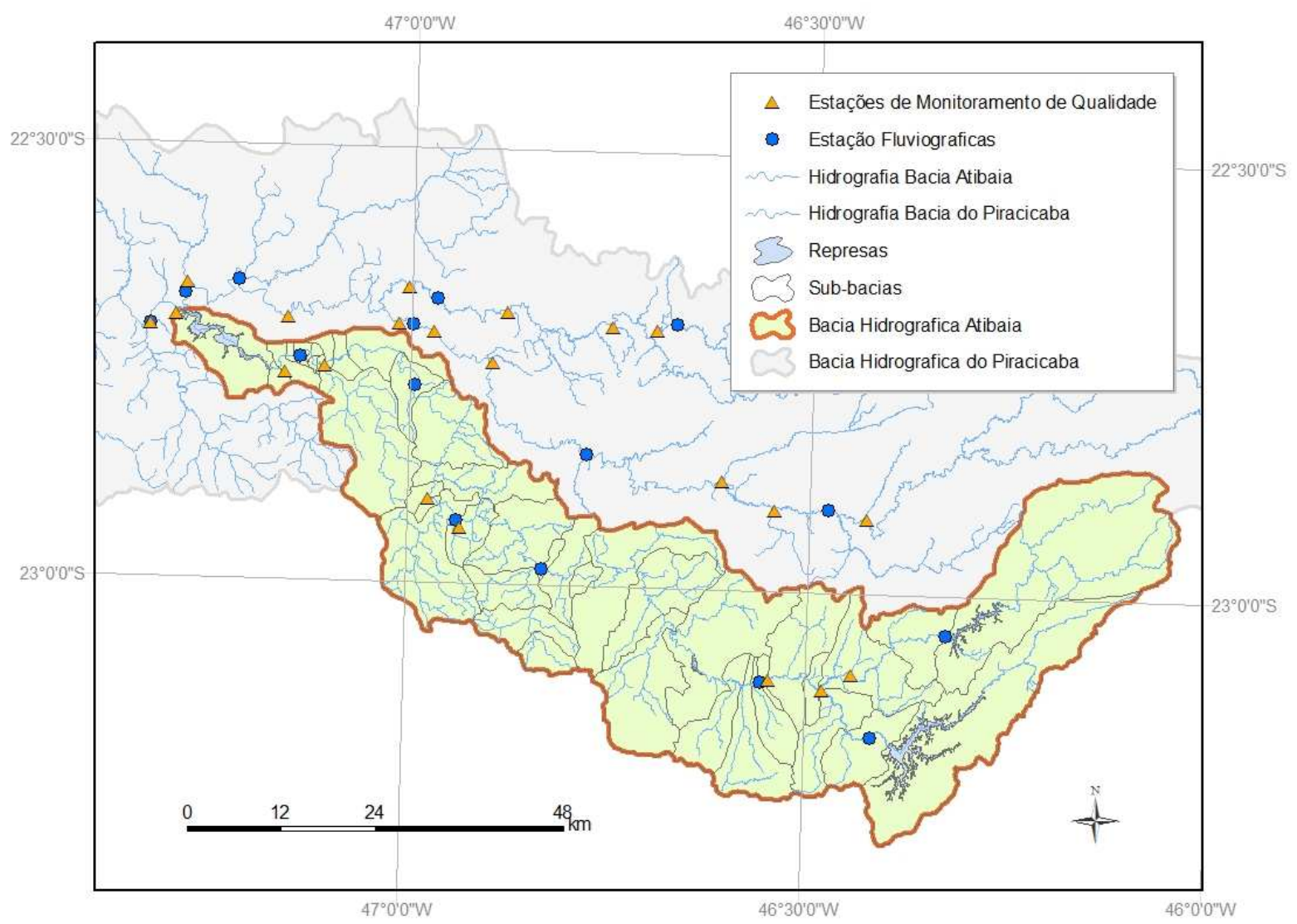

Figura 7.2 - Discretização da Bacia Hidrográfica do Rio Atibaia

As vazões naturais foram determinadas a partir dos dados do estudo de regionalização de vazões do Estado de São Paulo (DAEE). A vazão de referência adotada foi a vazão com $95 \%$ de permanência de ocorrência, $Q_{95 \%}$. 
Os dados de entrada do modelo referentes aos lançamentos de efluentes pontuais (vazão, OD e DBO), às demandas requeridas pelos usuários, dados da contribuição natural de cada sub-bacia, assim como, as finalidades de uso podem ser visualizados no Anexo III desta tese.

$\mathrm{Na}$ Tabela 7.1 são apresentados os parâmetros adotados para os algoritmos analisados para o estudo de caso do Rio Atibaia. Para o tamanho da população foi adotado o valor de dez vezes os número de variáveis, assim o tamanho da população é variável para cada estratégia analisada.

Tabela 7.1 - Parâmetros dos algoritmos analisados adotados para o estudo de caso

\begin{tabular}{c|c|c|c|c|c|c}
\hline \multicolumn{2}{c|}{ AG } & \multicolumn{3}{c|}{ PSO } & \multicolumn{2}{c}{ DE } \\
\hline $\begin{array}{c}\text { Probabilidade } \\
\text { de Mutação }\end{array}$ & $\begin{array}{c}\text { Probabilidade de } \\
\text { Cruzamento }\end{array}$ & W & $\mathrm{c}_{1}$ & $\mathrm{c}_{2}$ & $\mathrm{~F}$ & $\mathrm{CR}$ \\
\hline 0.005 & 0.95 & 0.8 & 1.4 & 1.4 & 0,9 & 0,8 \\
\hline
\end{tabular}

A seguir, são apresentadas as discussões dos resultados obtidos com a utilização do SSD na bacia do Rio Atibaia. O Item 7.1 trata da calibração automática dos parâmetros de DBO e OD e o Item 7.2 trata da utilização dos algoritmos de otimização para avaliação da outorga de efluentes.

\subsection{Calibração automática para o Rio Atibaia}

A calibração do modelo matemático é uma etapa fundamental para a obtenção de resultados precisos e seguros, no entanto, esta tarefa pode ser bastante árdua para a obtenção de bons resultados. Neste enfoque, a calibração automática auxilia este processo, tornando-se uma ferramenta importante no desenvolvimento dos SSDs, pois agiliza o processo.

No Rio Atibaia, existem oito estações de monitoramento de qualidade da água operadas pela CETESB, as quais são listadas na Tabela 7.2, e que foram utilizados para a calibração do modelo de qualidade da água.

Tabela 7.2 - Estações de qualidade da água utilizadas no estudo

\begin{tabular}{c|c|c|c|c|c}
\hline Bacia & Posto & \multicolumn{2}{|c|}{ Coordenadas } & Município & Período de dados \\
\hline \multirow{4}{*}{ Atibaia } & ATIB 02010 & $23^{0} 06^{\prime} 12^{\prime \prime}$ & $46^{0} 32^{\prime} 42^{\prime \prime}$ & Atibaia & $1995-2009$ \\
\cline { 2 - 6 } & ATIB 02030 & $22^{0} 58^{\prime} 11^{\prime \prime}$ & $46^{0} 50^{\prime} 48^{\prime \prime}$ & Itatiba & $2002-2009$ \\
\cline { 2 - 6 } & ATIB 02035 & $22^{0} 56^{\prime} 16^{\prime \prime}$ & $46^{0} 56^{\prime} 01 "$ & Valinhos & $2000-2009$ \\
\hline
\end{tabular}




\begin{tabular}{c|c|c|c|c|c}
\hline Bacia & Posto & \multicolumn{2}{|c|}{ Coordenadas } & Município & Período de dados \\
\hline \multirow{2}{*}{ ATIB 02065 } & $22^{0} 54^{\prime} 18^{\prime \prime}$ & $46^{0} 58^{\prime} 26^{\prime \prime}$ & Campinas & $1989-2009$ \\
\cline { 2 - 6 } & ATIB 02300 & $22^{0} 45^{\prime} 07^{\prime \prime}$ & $47^{0} 06^{\prime} 20^{\prime \prime}$ & Paulínia & $2000-2009$ \\
\cline { 2 - 6 } & ATIB 02605 & $22^{0} 44^{\prime} 43^{\prime \prime}$ & $47^{0} 09^{\prime} 35^{\prime \prime}$ & Paulínia & $1989-2009$ \\
\cline { 2 - 6 } & ATIB 02800 & $22^{0} 45^{\prime} 41^{\prime \prime}$ & $47^{0} 10^{\prime} 24^{\prime \prime}$ & Paulínia & $2002-2009$ \\
\cline { 2 - 6 } & ATIB 02900 & $22^{0} 41^{\prime} 54^{\prime \prime}$ & $47^{0} 17^{\prime} 27^{\prime \prime}$ & Americana & $2000-2006$ \\
\hline
\end{tabular}

No Anexo II, são apresentados os valores estatísticos obtidos para cada estação de monitoramento utilizados na obtenção dos gráficos Box-Plot no Rio Atibaia, assim como as demais características dos trechos necessárias como entrada de dados para o modelo. Os gráficos Box-Plot foram utilizados para a calibração do modelo de qualidade da água. Para a obtenção da calibração automática dos parâmetros DBO e OD foram analisados os algoritmos evolutivos AG, PSO e DE e a função objetivo a ser solucionada, conforme apresentados no Item 6.2.1 desta tese.

Observa-se que o esforço computacional necessário para a solução do problema está relacionado com o número de variáveis. Como esta aplicação tem 54 trechos e para cada trecho existem três constantes de qualidade da água, por trecho, a serem otimizadas $\left(k_{a}, k_{d}\right.$ e $\left.k_{s}\right)$, o total de variáveis nesta aplicação é 162.

Os limites mínimos e máximos dos coeficientes $\mathrm{k}_{\mathrm{a}}, \mathrm{k}_{\mathrm{d}}$ e $\mathrm{k}_{\mathrm{s}}$, os quais representam os limites para o espaço de busca de cada variável, são dados de entrada do modelo e podem sofrer variações entre os trechos, buscando a melhor representatividade das características de cada trecho a ser simulado. Os valores de $\mathrm{k}_{\mathrm{a}}$ variaram de 0,1 a 6,0 para todos os trechos, os valores de $k_{d}$ variaram de 0,1 a 1,6 para os trechos mais próximos a cabeceira e de 0,1 a 1,6 para os trechos de jusante os valores de $k_{s}$ variam de 0 a 1,0.

Os valores de limites adotados para os coeficientes de velocidade e de profundidade, a classe de enquadramento em que o trecho está classificado e o valores comprimento do trecho, para todos os trechos simulados do Rio Atibaia podem ser visualizados na tabela que se encontra no Anexo III.

Os resultados estatísticos obtidos para a função objetivo (FO) nas 50 simulações do rio Atibaia são apresentados na Tabela 7.3. Os algoritmos AG e DE apresentaram resultados muito próximos para a solução da função objetivo. A diferença entre os valores mínimos e máximos, obtidos da função objetivo nas 50 simulações, foi pequena, assim como apresentaram desvio padrão próximo, o qual representa o grau de dispersão dos valores em relação ao valor médio. O PSO apresentou uma maior amplitude para os valores da função objetivo para as 50 simulações realizadas, assim como apresentou maior desvio 
padrão que os resultados obtidos com $\circ A G$ e $\circ D E$. Esta análise não significa que 0 algoritmo PSO não possa ser aplicado para o processo de calibração automática.

Tabela 7.3 - Dados estatísticos dos valores da FO, obtidos para o AG, PSO e DE no Rio Atibaia

\begin{tabular}{c|c|c|c}
\hline Algoritmo & FO - AG & FO - PSO & FO - DE \\
\hline Mínimo & 1.464670 & 1.491925 & 1.464453 \\
\hline Máximo & 1.464787 & 1.841802 & 1.464539 \\
\hline Média & 1.464728 & 1.620012 & 1.464476 \\
\hline Desvio Padrão & 0.000026 & 0.076226 & 0.000022 \\
\hline
\end{tabular}

A Figura 7.3, Figura 7.4 e Figura 7.5 apresentam os perfis de DBO para as 50 simulações do rio Atibaia utilizando o AG, PSO e DE, respectivamente. Nas Figuras podem ser visualizadas as estruturas de Box-plots dos oito pontos de monitoramento considerados.

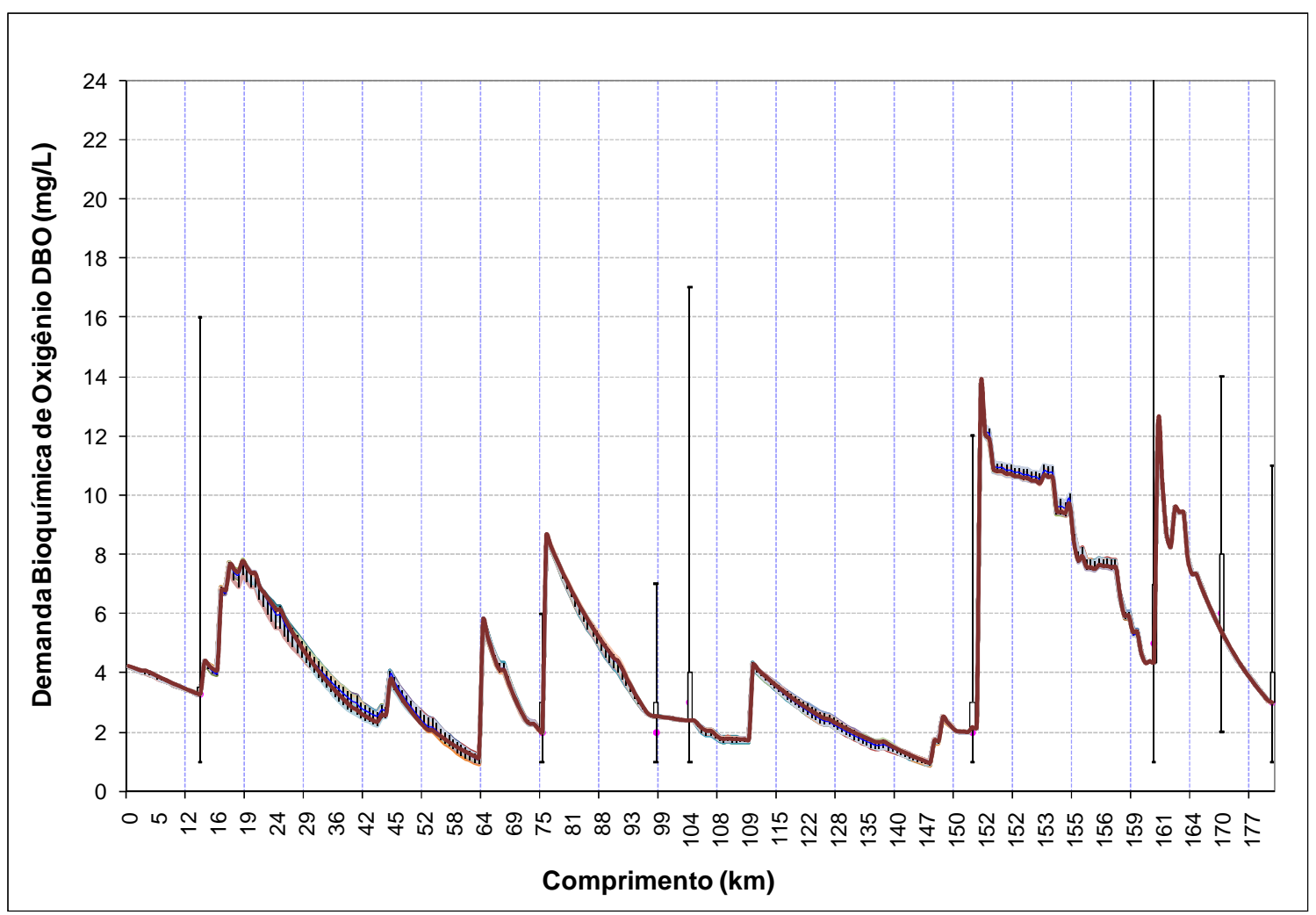

Figura 7.3 - Perfil de DBO no rio Atibaia obtido com AG 


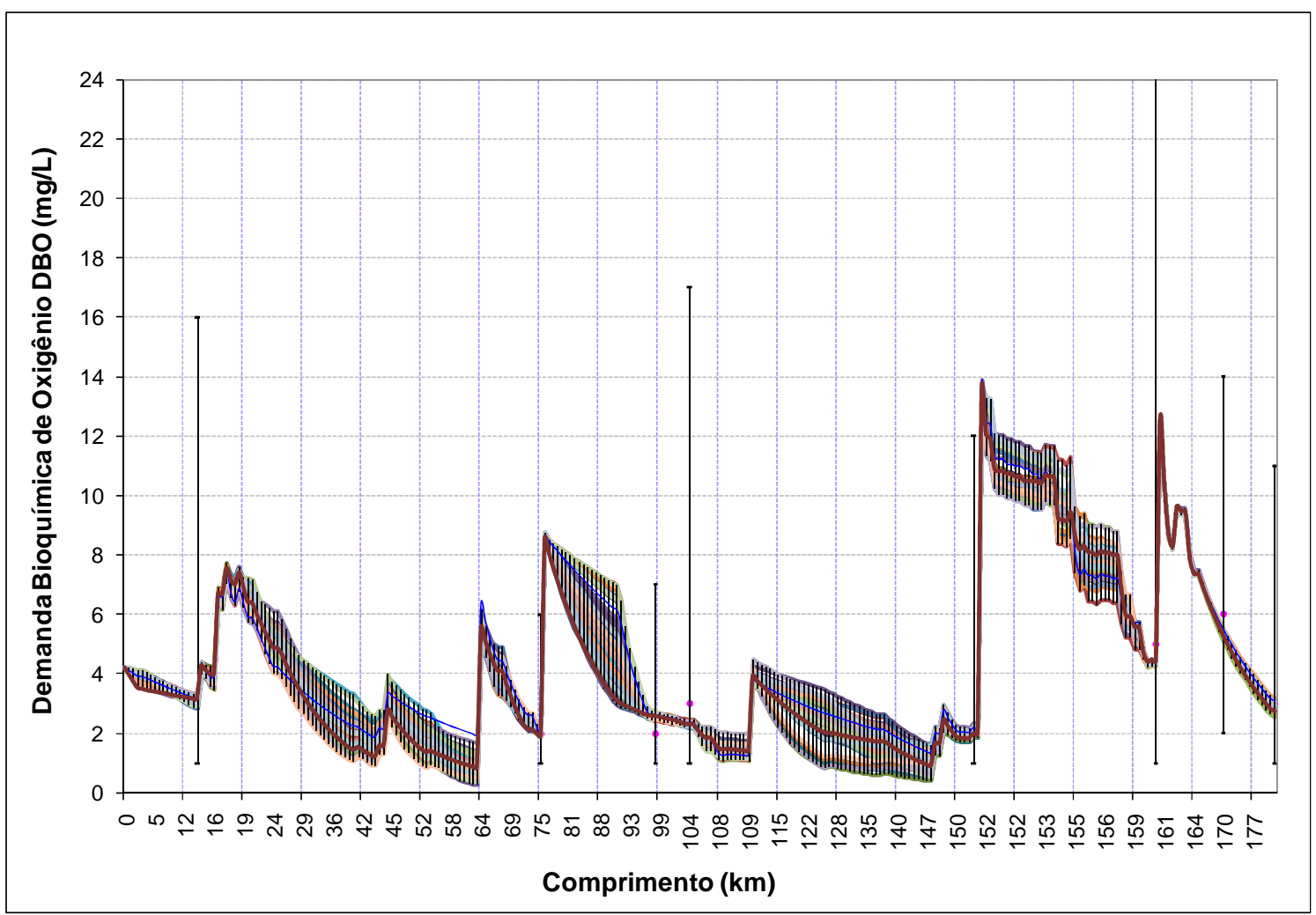

Figura 7.4- Perfil de DBO no rio Atibaia obtido com PSO

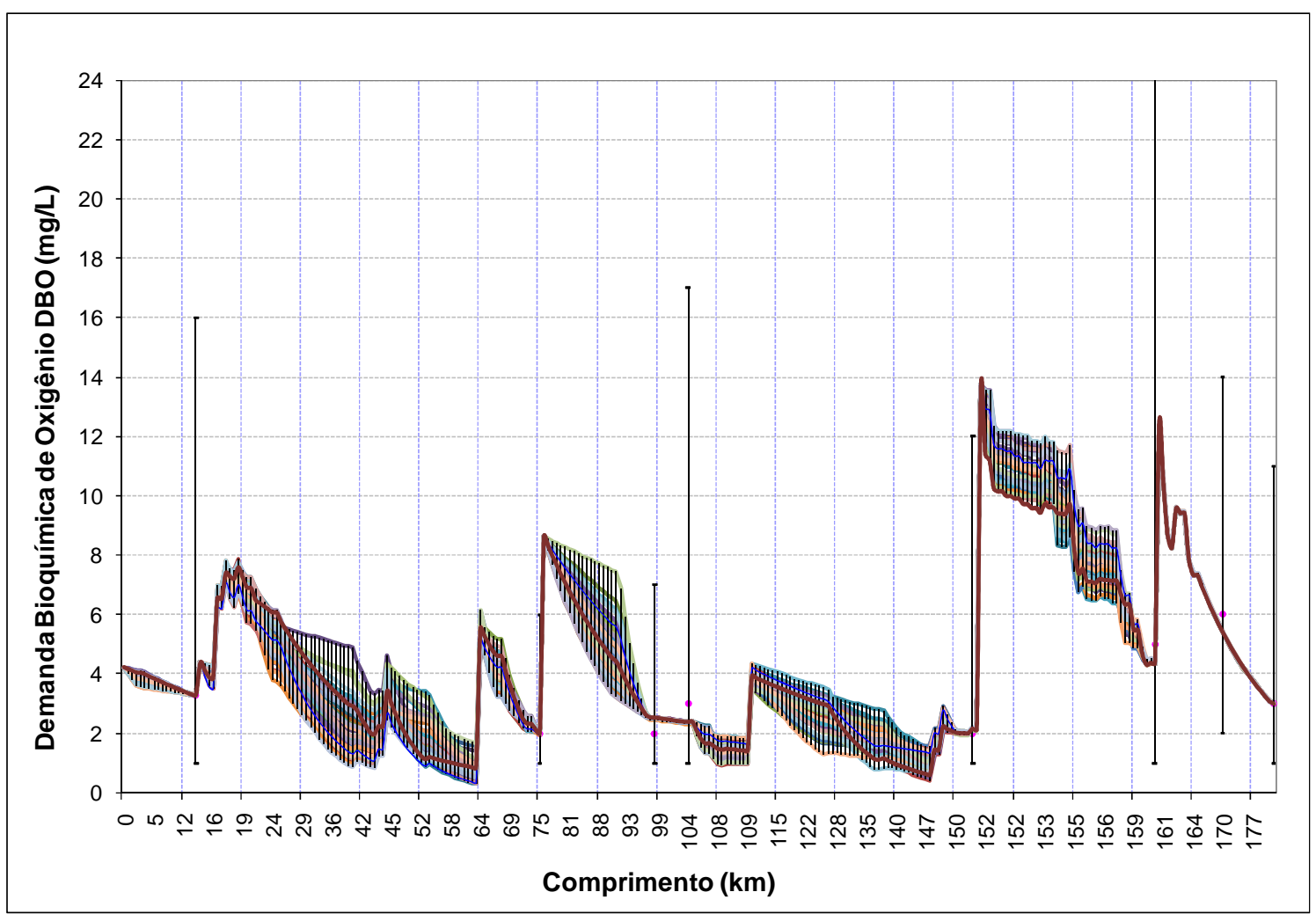

Figura 7.5 - Perfil de DBO no rio Atibaia obtido com DE

Conforme observado na Figura 7.3, Figura 7.4 e Figura 7.5, o perfil de DBO do Rio Atibaia para as 50 simulações realizadas com os algoritmos AG, SPO e DE, indicou que o 
AG apresentou menor dispersão nos perfis do parâmetro para os trechos intermediários entre as estações de monitoramento.

A Figura 7.6, Figura 7.7 e Figura 7.8 apresentam os perfis de OD das 50 simulações no Rio Atibaia utilizando o AG, PSO e DE, respectivamente.

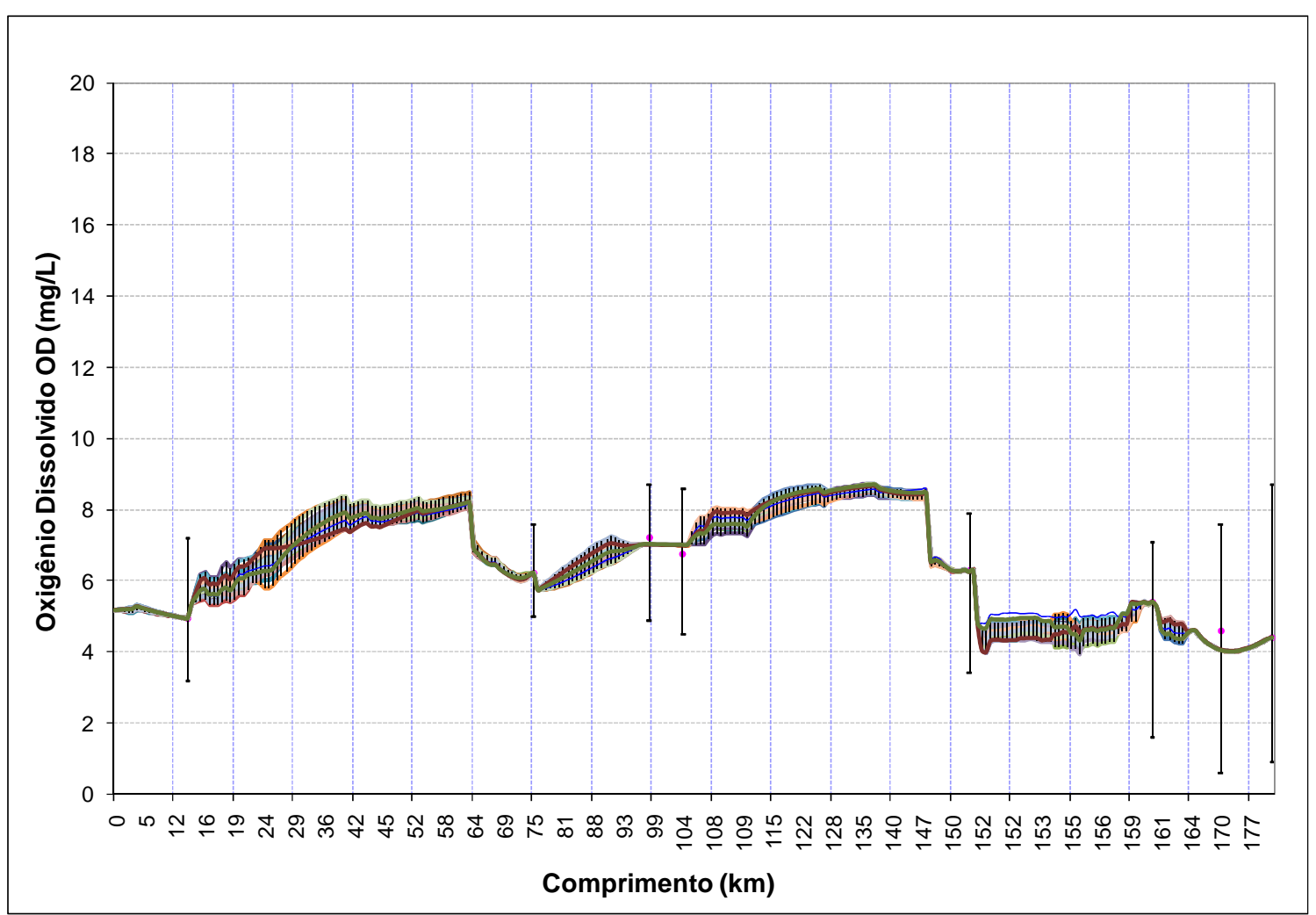

Figura 7.6 - Perfil de OD no rio Atibaia obtido com AG 


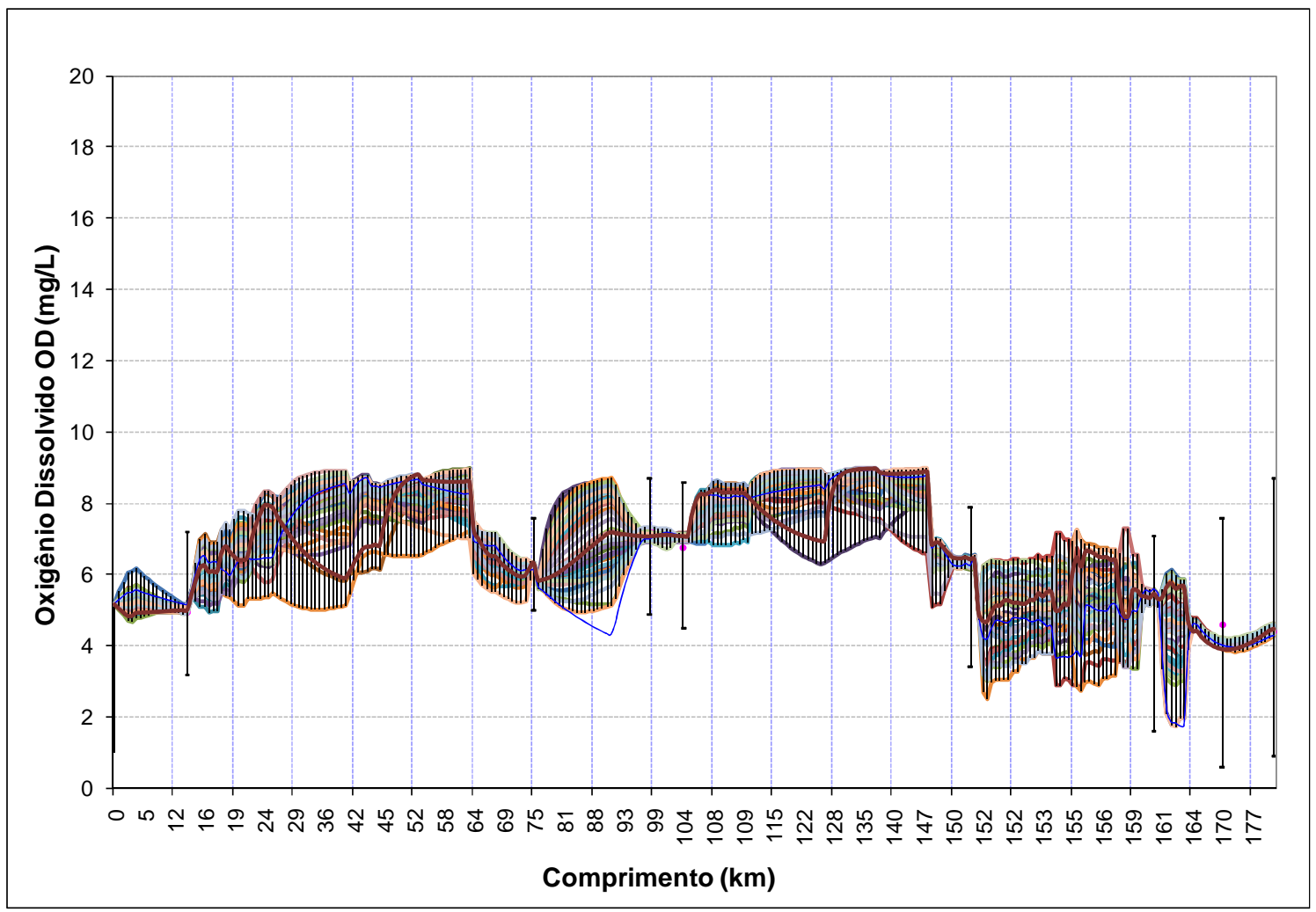

Figura 7.7 - Perfil de OD no rio Atibaia obtido com PSO

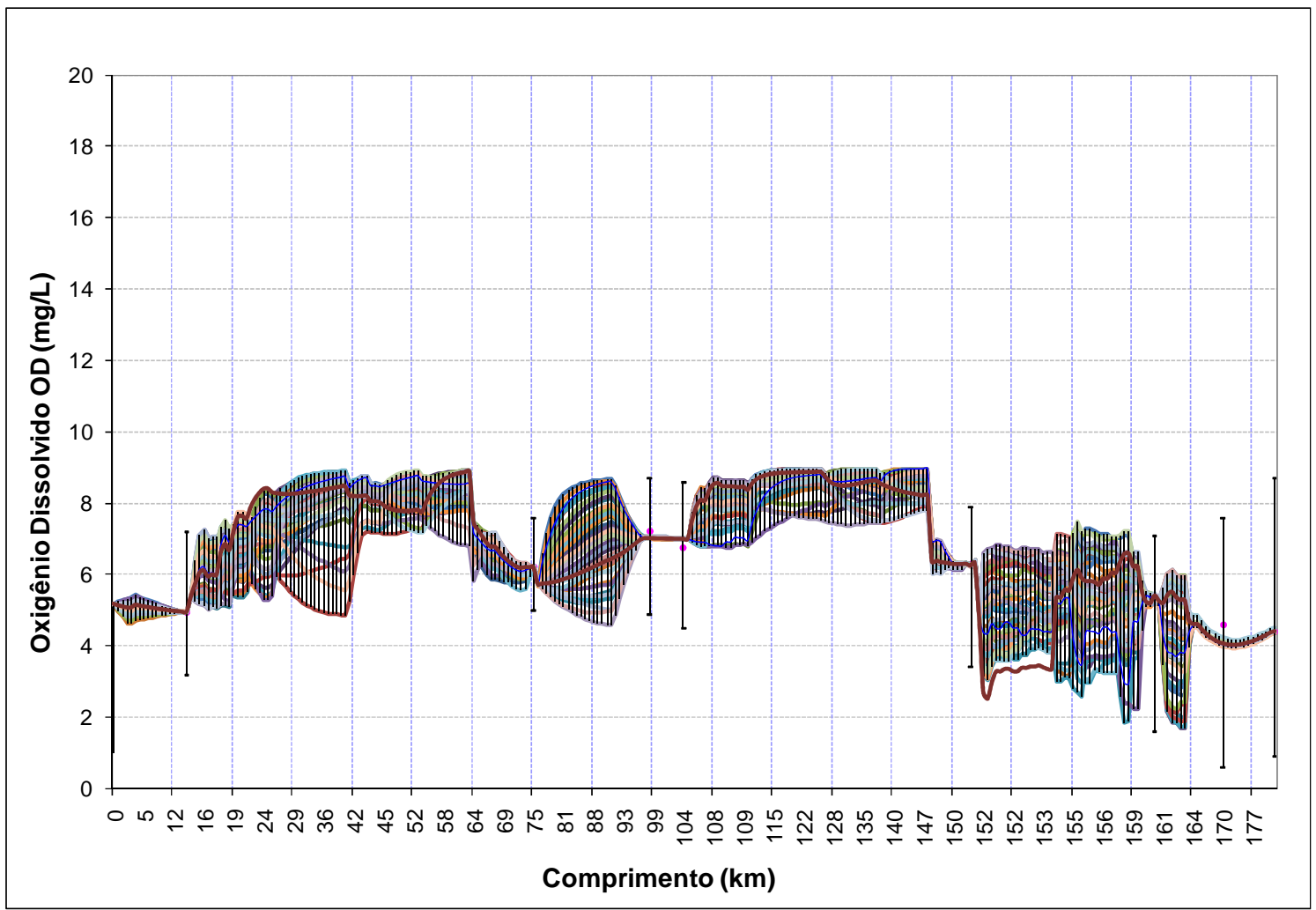

Figura 7.8 - Perfil de OD no rio Atibaia obtido com DE

O perfil do parâmetro OD teve comportamento similar ao do parâmetro BDO, quando realizadas as 50 simulações, onde a menor dispersão foi obtida com o algoritmo AG. 
Os perfis de OD e DBO apresentados nas Figura 7.3 a Figura 7.8, apesar da dispersão observada para as 50 simulações, apresentaram bom desempenho para a função objetivo na calibração do rio Atibaia para os três algoritmos utilizados. Esta análise indica que existem diversas soluções possíveis para o problema proposto.

Os resultados obtidos para os coeficientes $\mathrm{Ka}, \mathrm{Kd}$ e $\mathrm{Ks}$, em cada trecho, das 50 simulações com os algoritmos AG, PSO e DE no Rio Atibaia pode ser observado na Tabela 7.4 , onde estão disponibilizados os valores médios e o desvio padrão para os coeficientes em questão. 
Tabela 7.4- Coeficientes obtidos nas 50 simulações com AG, PSO e DE no Rio Atibaia

\begin{tabular}{|c|c|c|c|c|c|c|c|c|c|c|c|c|c|c|c|c|c|c|}
\hline \multirow{3}{*}{ Trecho } & \multicolumn{6}{|c|}{$\mathrm{Ka}$} & \multicolumn{6}{|c|}{ kd } & \multicolumn{6}{|c|}{ Ks } \\
\hline & \multicolumn{2}{|c|}{$\mathbf{A G}$} & \multicolumn{2}{|c|}{ PSO } & \multicolumn{2}{|c|}{$\overline{D E}$} & \multicolumn{2}{|c|}{$\overline{A G}$} & \multicolumn{2}{|c|}{ PSO } & \multicolumn{2}{|c|}{ DE } & \multicolumn{2}{|c|}{$\mathbf{A G}$} & \multicolumn{2}{|c|}{ PSO } & \multicolumn{2}{|c|}{$\overline{D E}$} \\
\hline & Média & $\begin{array}{l}\text { Desv } \\
\text { Padrão }\end{array}$ & Média & $\begin{array}{l}\text { Desv } \\
\text { Padrão }\end{array}$ & Média & $\begin{array}{c}\text { Desv } \\
\text { Padrão }\end{array}$ & Média & $\begin{array}{l}\text { Desv } \\
\text { Padrão }\end{array}$ & Média & $\begin{array}{c}\text { Desv } \\
\text { Padrão }\end{array}$ & Média & $\begin{array}{l}\text { Desv } \\
\text { Padrão }\end{array}$ & Média & $\begin{array}{c}\text { Desv } \\
\text { Padrão }\end{array}$ & Média & $\begin{array}{c}\text { Desv } \\
\text { Padrão }\end{array}$ & Média & $\begin{array}{l}\text { Desv } \\
\text { Padrão }\end{array}$ \\
\hline 1 & 0.26 & 0.0278 & 0.37 & 0.3044 & 0.20 & 0.0919 & 0.22 & 0.0283 & 0.39 & 0.2239 & 0.44 & 0.2253 & 0.04 & 0.0096 & 0.12 & 0.1203 & 0.10 & 0.0943 \\
\hline 2 & 0.14 & 0.0068 & 0.14 & 0.0410 & 0.13 & 0.0260 & 0.28 & 0.0093 & 0.25 & 0.0982 & 0.20 & 0.0677 & 0.01 & 0.0035 & 0.04 & 0.0469 & 0.02 & 0.0187 \\
\hline 3 & 1.45 & 0.4230 & 2.88 & 1.3737 & 2.99 & 1.8146 & 0.32 & 0.0736 & 0.52 & 0.2521 & 0.59 & 0.3011 & 0.20 & 0.0570 & 0.36 & 0.2406 & 0.31 & 0.2676 \\
\hline 4 & 1.44 & 0.4222 & 3.21 & 1.5172 & 2.81 & 1.7841 & 0.29 & 0.0705 & 0.60 & 0.2378 & 0.56 & 0.2885 & 0.17 & 0.0587 & 0.38 & 0.2040 & 0.43 & 0.2582 \\
\hline 5 & 1.41 & 0.3773 & 3.39 & 1.6457 & 2.87 & 1.7734 & 0.32 & 0.0833 & 0.51 & 0.2763 & 0.50 & 0.2813 & 0.20 & 0.0502 & 0.37 & 0.2115 & 0.41 & 0.2675 \\
\hline 6 & 1.52 & 0.4132 & 2.88 & 1.7367 & 3.27 & 1.8341 & 0.33 & 0.0670 & 0.55 & 0.2621 & 0.49 & 0.2906 & 0.21 & 0.0587 & 0.42 & 0.2398 & 0.40 & 0.2836 \\
\hline 7 & 1.58 & 0.4739 & 2.98 & 1.5739 & 2.77 & 2.0437 & 0.35 & 0.0504 & 0.53 & 0.2684 & 0.56 & 0.3119 & 0.23 & 0.0619 & 0.43 & 0.2063 & 0.34 & 0.2410 \\
\hline 8 & 1.92 & 0.3387 & 2.81 & 1.6976 & 3.49 & 1.8280 & 0.43 & 0.0413 & 0.57 & 0.2382 & 0.54 & 0.3084 & 0.27 & 0.0493 & 0.38 & 0.1755 & 0.41 & 0.2649 \\
\hline 9 & 1.70 & 0.3414 & 3.35 & 1.6347 & 3.45 & 1.8505 & 0.35 & 0.0594 & 0.52 & 0.2498 & 0.58 & 0.2920 & 0.21 & 0.0415 & 0.43 & 0.2162 & 0.40 & 0.2475 \\
\hline 10 & 1.50 & 0.3434 & 2.74 & 1.5617 & 3.24 & 1.9428 & 0.31 & 0.0656 & 0.59 & 0.2455 & 0.60 & 0.3116 & 0.16 & 0.0456 & 0.41 & 0.2073 & 0.51 & 0.2277 \\
\hline 11 & 1.73 & 0.2799 & 2.52 & 1.7567 & 2.71 & 1.9500 & 0.43 & 0.0553 & 0.56 & 0.2355 & 0.57 & 0.3149 & 0.62 & 0.0831 & 0.76 & 0.4528 & 0.80 & 0.5306 \\
\hline 12 & 1.29 & 0.1788 & 1.84 & 1.6373 & 2.07 & 1.8726 & 0.50 & 0.0586 & 0.58 & 0.2832 & 0.56 & 0.2992 & 0.68 & 0.0817 & 0.75 & 0.4248 & 0.71 & 0.4531 \\
\hline 13 & 0.73 & 0.0795 & 0.63 & 0.4916 & 0.69 & 0.6094 & 0.72 & 0.0476 & 0.81 & 0.1622 & 0.77 & 0.2219 & 0.79 & 0.0855 & 0.80 & 0.3748 & 0.69 & 0.5256 \\
\hline 14 & 0.44 & 0.0510 & 0.39 & 0.2510 & 0.35 & 0.2381 & 0.83 & 0.0304 & 0.80 & 0.1443 & 0.86 & 0.1335 & 0.98 & 0.0594 & 0.79 & 0.3902 & 0.81 & 0.4094 \\
\hline 15 & 0.77 & 0.1229 & 0.79 & 0.6162 & 0.76 & 0.5277 & 0.59 & 0.0566 & 0.59 & 0.2267 & 0.64 & 0.2678 & 0.82 & 0.1065 & 0.92 & 0.3745 & 0.92 & 0.5154 \\
\hline 16 & 1.15 & 0.1242 & 1.64 & 1.2592 & 1.74 & 1.2082 & 0.35 & 0.0250 & 0.34 & 0.1981 & 0.36 & 0.1768 & 0.27 & 0.0276 & 0.19 & 0.1902 & 0.19 & 0.1386 \\
\hline 17 & 0.97 & 0.1125 & 1.05 & 0.7591 & 0.98 & 0.6874 & 0.51 & 0.0446 & 0.62 & 0.2655 & 0.64 & 0.2671 & 0.46 & 0.0470 & 0.54 & 0.3926 & 0.50 & 0.3425 \\
\hline 18 & 0.10 & 0.0001 & 0.16 & 0.0801 & 0.10 & 0.0000 & 0.10 & 0.0000 & 0.14 & 0.0688 & 0.10 & 0.0000 & 0.00 & 0.0000 & 0.02 & 0.0287 & 0.00 & 0.0000 \\
\hline 19 & 0.10 & 0.0002 & 0.22 & 0.2048 & 0.10 & 0.0001 & 0.10 & 0.0001 & 0.17 & 0.1193 & 0.10 & 0.0000 & 0.00 & 0.0000 & 0.04 & 0.0756 & 0.00 & 0.0000 \\
\hline 20 & 1.42 & 0.4041 & 2.76 & 1.5947 & 3.25 & 1.9367 & 0.32 & 0.0460 & 0.52 & 0.2349 & 0.54 & 0.3086 & 0.41 & 0.0689 & 0.68 & 0.4347 & 0.89 & 0.5480 \\
\hline 21 & 1.40 & 0.3772 & 2.78 & 1.7288 & 3.10 & 2.1755 & 0.32 & 0.0464 & 0.57 & 0.2499 & 0.47 & 0.2505 & 0.41 & 0.0788 & 0.66 & 0.4371 & 0.86 & 0.5827 \\
\hline 22 & 1.39 & 0.3727 & 3.43 & 1.7974 & 2.94 & 2.1032 & 0.31 & 0.0691 & 0.54 & 0.2614 & 0.53 & 0.2862 & 0.36 & 0.1394 & 0.73 & 0.5195 & 0.91 & 0.4805 \\
\hline 23 & 1.48 & 0.4484 & 2.87 & 1.6276 & 3.07 & 1.9804 & 0.30 & 0.0614 & 0.52 & 0.2357 & 0.46 & 0.2904 & 0.36 & 0.0892 & 0.76 & 0.4010 & 0.82 & 0.5740 \\
\hline 24 & 1.33 & 0.3610 & 3.19 & 1.4328 & 2.84 & 2.0178 & 0.31 & 0.0820 & 0.48 & 0.2526 & 0.49 & 0.2771 & 0.00 & 0.0000 & 0.00 & 0.0000 & 0.00 & 0.0000 \\
\hline 25 & 1.75 & 0.2854 & 2.54 & 1.6179 & 3.51 & 1.9400 & 0.30 & 0.0207 & 0.25 & 0.1859 & 0.20 & 0.1160 & 0.00 & 0.0000 & 0.00 & 0.0000 & 0.00 & 0.0000 \\
\hline 26 & 1.57 & 0.2819 & 2.77 & 1.7993 & 2.75 & 1.8203 & 0.32 & 0.0288 & 0.32 & 0.1727 & 0.35 & 0.2076 & 0.00 & 0.0000 & 0.00 & 0.0000 & 0.00 & 0.0000 \\
\hline 27 & 0.85 & 0.1365 & 1.71 & 1.5488 & 1.91 & 1.7592 & 0.41 & 0.0422 & 0.40 & 0.2271 & 0.38 & 0.2216 & 0.00 & 0.0000 & 0.00 & 0.0000 & 0.00 & 0.0000 \\
\hline 28 & 1.34 & 0.1921 & 2.71 & 1.7072 & 2.09 & 1.7418 & 0.32 & 0.0497 & 0.57 & 0.2397 & 0.54 & 0.2927 & 0.00 & 0.0000 & 0.00 & 0.0000 & 0.00 & 0.0000 \\
\hline
\end{tabular}




\begin{tabular}{|c|c|c|c|c|c|c|c|c|c|c|c|c|c|c|c|c|c|c|}
\hline \multirow{3}{*}{ Trecho } & \multicolumn{6}{|c|}{$\mathrm{Ka}$} & \multicolumn{6}{|c|}{ kd } & \multicolumn{6}{|c|}{ Ks } \\
\hline & \multicolumn{2}{|c|}{$\mathbf{A G}$} & \multicolumn{2}{|c|}{ PSO } & \multicolumn{2}{|c|}{ DE } & \multicolumn{2}{|c|}{$\mathbf{A G}$} & \multicolumn{2}{|c|}{ PSO } & \multicolumn{2}{|c|}{ DE } & \multicolumn{2}{|c|}{$\mathbf{A G}$} & \multicolumn{2}{|c|}{ PSO } & \multicolumn{2}{|c|}{$\mathrm{DE}$} \\
\hline & Média & $\begin{array}{c}\text { Desv } \\
\text { Padrão }\end{array}$ & Média & $\begin{array}{l}\text { Desv } \\
\text { Padrão }\end{array}$ & Média & $\begin{array}{l}\text { Desv } \\
\text { Padrão }\end{array}$ & Média & $\begin{array}{l}\text { Desv } \\
\text { Padrão }\end{array}$ & Média & $\begin{array}{c}\text { Desv } \\
\text { Padrão }\end{array}$ & Média & $\begin{array}{l}\text { Desv } \\
\text { Padrão }\end{array}$ & Média & $\begin{array}{l}\text { Desv } \\
\text { Padrão }\end{array}$ & Média & $\begin{array}{l}\text { Desv } \\
\text { Padrão }\end{array}$ & Média & $\begin{array}{l}\text { Desv } \\
\text { Padrão }\end{array}$ \\
\hline 29 & 0.24 & 0.0297 & 0.30 & 0.2834 & 0.21 & 0.1113 & 0.58 & 0.0339 & \begin{tabular}{|l|}
0.67 \\
\end{tabular} & 0.2116 & 0.66 & 0.2255 & 0.00 & 0.0000 & 0.00 & 0.0000 & 0.00 & 0.0000 \\
\hline 30 & 1.21 & \begin{tabular}{|l|}
0.1999 \\
\end{tabular} & 2.01 & 1.2962 & 1.86 & 1.4603 & 0.49 & 0.0845 & \begin{tabular}{|l|}
0.90 \\
\end{tabular} & \begin{tabular}{|l|}
0.4049 \\
\end{tabular} & 0.97 & 0.5101 & 0.00 & 0.0000 & 0.00 & 0.0000 & 0.00 & 0.0000 \\
\hline 31 & 1.59 & 0.4902 & 3.12 & 1.5698 & 2.68 & 1.8660 & 0.49 & 0.1097 & 0.85 & 0.3752 & 0.84 & 0.5425 & 0.00 & 0.0000 & 0.00 & 0.0000 & 0.00 & 0.0000 \\
\hline 32 & 2.13 & 0.3159 & 3.13 & 1.6544 & 3.15 & 2.0334 & 1.06 & 0.0640 & 1.02 & 0.4244 & 0.92 & 0.4724 & 0.00 & 0.0000 & 0.00 & 0.0000 & 0.00 & 0.0000 \\
\hline 33 & 1.59 & 0.3319 & 2.76 & 1.6482 & 2.80 & 1.8962 & 0.58 & 0.0833 & \begin{tabular}{|l|}
0.82 \\
\end{tabular} & 0.3998 & 0.89 & 0.4926 & 0.00 & 0.0000 & 0.00 & 0.0000 & 0.00 & 0.0000 \\
\hline 34 & 1.66 & 0.3919 & 3.11 & 1.8430 & 3.06 & 1.9883 & 0.57 & 0.0825 & 0.95 & 0.4042 & 0.79 & 0.4918 & 0.00 & 0.0000 & 0.00 & 0.0000 & 0.00 & 0.0000 \\
\hline 35 & 1.75 & \begin{tabular}{|l|l|}
0.4982 \\
\end{tabular} & 3.14 & 1.8505 & 2.89 & 1.8864 & 0.59 & 0.0850 & \begin{tabular}{|l|}
0.87 \\
\end{tabular} & \begin{tabular}{|l|l}
0.4419 \\
\end{tabular} & 0.90 & 0.4817 & 0.00 & 0.0000 & 0.00 & 0.0000 & 0.00 & 0.0000 \\
\hline 36 & 1.66 & 0.3813 & 3.06 & 1.5881 & 3.02 & 1.7347 & 0.58 & 0.0818 & 0.83 & 0.4193 & 0.84 & 0.5386 & 0.00 & 0.0000 & 0.00 & 0.0000 & 0.00 & 0.0000 \\
\hline 37 & 1.63 & 0.3393 & 3.29 & 1.4601 & 3.02 & 1.7786 & 0.55 & 0.0850 & \begin{tabular}{|l|}
0.88 \\
\end{tabular} & 0.4477 & 0.89 & 0.5437 & 0.00 & 0.0000 & 0.00 & 0.0000 & 0.00 & 0.0000 \\
\hline 38 & 1.63 & 0.3252 & 3.37 & 1.6307 & 2.75 & 2.0351 & 0.57 & 0.0781 & 0.88 & 0.4711 & 0.85 & 0.4828 & 0.00 & 0.0000 & 0.00 & 0.0000 & 0.00 & 0.0000 \\
\hline 39 & 1.69 & 0.3435 & 3.04 & 1.6581 & 2.55 & 1.9616 & 0.57 & 0.0910 & 0.75 & 0.4231 & 0.87 & 0.5351 & 0.00 & 0.0000 & 0.00 & 0.0000 & 0.00 & 0.0000 \\
\hline 40 & 2.23 & \begin{tabular}{|l|}
0.3295 \\
\end{tabular} & 2.56 & 1.5091 & 3.53 & 1.7554 & 1.04 & 0.0633 & \begin{tabular}{|l|}
0.90 \\
\end{tabular} & \begin{tabular}{|l|l|}
0.4372 \\
\end{tabular} & 0.99 & 0.4977 & 0.00 & 0.0000 & 0.00 & 0.0000 & 0.00 & 0.0000 \\
\hline 41 & 1.69 & \begin{tabular}{|l|}
0.2818 \\
\end{tabular} & 3.31 & 1.7990 & 2.88 & 1.8603 & 0.58 & 0.0847 & \begin{tabular}{|l|}
0.83 \\
\end{tabular} & 0.4325 & 0.92 & 0.4978 & 0.00 & 0.0000 & 0.00 & 0.0000 & 0.00 & 0.0000 \\
\hline 42 & 2.41 & \begin{tabular}{|l|}
0.2769 \\
\end{tabular} & 2.61 & 1.6003 & 2.78 & 1.9384 & 1.20 & 0.0524 & \begin{tabular}{|l|}
1.12 \\
\end{tabular} & \begin{tabular}{|l|}
0.3794 \\
\end{tabular} & 1.07 & 0.4398 & 0.00 & 0.0000 & 0.00 & 0.0000 & 0.00 & 0.0000 \\
\hline 43 & 2.25 & 0.3120 & 2.92 & 1.5793 & 3.08 & 2.0247 & 0.83 & 0.0818 & \begin{tabular}{|l|}
0.86 \\
\end{tabular} & \begin{tabular}{|l|}
0.4368 \\
\end{tabular} & 0.92 & 0.4961 & 0.00 & 0.0000 & 0.00 & 0.0000 & 0.00 & 0.0000 \\
\hline 44 & 1.75 & 0.3393 & 2.81 & 1.8859 & 3.44 & 2.1034 & 0.57 & 0.0971 & 0.87 & 0.4331 & 1.01 & 0.4825 & 0.00 & 0.0000 & 0.00 & 0.0000 & 0.00 & 0.0000 \\
\hline 45 & 1.85 & 0.3612 & 3.09 & 1.8494 & 2.75 & 1.9723 & 0.55 & 0.0908 & 0.93 & 0.4160 & 0.94 & 0.5221 & 0.00 & 0.0000 & 0.00 & 0.0000 & 0.00 & 0.0000 \\
\hline 46 & 1.86 & \begin{tabular}{|l|l|}
0.3138 \\
\end{tabular} & 2.83 & 1.6616 & 3.17 & 2.0164 & 0.58 & 0.0893 & \begin{tabular}{|l|}
0.84 \\
\end{tabular} & \begin{tabular}{|l|l|}
0.3705 \\
\end{tabular} & 0.78 & 0.4317 & 0.00 & 0.0000 & 0.00 & 0.0000 & 0.00 & 0.0000 \\
\hline 47 & 2.21 & \begin{tabular}{|l|}
0.1899 \\
\end{tabular} & 1.64 & 1.1837 & 1.90 & 1.4624 & 1.26 & 0.0399 & \begin{tabular}{|l|}
1.16 \\
\end{tabular} & \begin{tabular}{|l|}
0.2757 \\
\end{tabular} & 1.23 & 0.3363 & 0.00 & 0.0000 & 0.00 & 0.0000 & 0.00 & 0.0000 \\
\hline 48 & 2.26 & \begin{tabular}{|l|}
0.2441 \\
\end{tabular} & 2.24 & 1.4336 & 2.46 & 1.6815 & 1.06 & 0.0606 & \begin{tabular}{|l|}
1.09 \\
\end{tabular} & \begin{tabular}{|l|}
0.4021 \\
\end{tabular} & 1.00 & 0.4405 & 0.00 & 0.0000 & 0.00 & 0.0000 & 0.00 & 0.0000 \\
\hline 49 & 1.94 & \begin{tabular}{|l|}
0.1527 \\
\end{tabular} & 1.86 & 1.0213 & 1.53 & 1.1983 & 1.24 & 0.0403 & \begin{tabular}{|l|}
1.30 \\
\end{tabular} & \begin{tabular}{|l|}
0.2857 \\
\end{tabular} & 1.28 & 0.2573 & 0.00 & 0.0000 & 0.00 & 0.0000 & 0.00 & 0.0000 \\
\hline 50 & 1.88 & \begin{tabular}{|l|}
0.2968 \\
\end{tabular} & 2.98 & 1.6562 & 3.25 & 1.8926 & 0.55 & 0.0851 & \begin{tabular}{|l|}
0.84 \\
\end{tabular} & \begin{tabular}{|l|}
0.3870 \\
\end{tabular} & 0.83 & 0.5336 & 0.00 & 0.0000 & 0.00 & 0.0000 & 0.00 & 0.0000 \\
\hline 51 & 3.39 & 0.1925 & 3.52 & 1.5234 & 3.43 & 1.7596 & 1.60 & 0.0000 & \begin{tabular}{|l|}
1.60 \\
\end{tabular} & \begin{tabular}{|l|l|}
0.0027 \\
\end{tabular} & 1.60 & 0.0000 & 0.00 & 0.0000 & 0.00 & 0.0000 & 0.00 & 0.0000 \\
\hline 52 & 2.76 & \begin{tabular}{|l|}
0.3649 \\
\end{tabular} & 3.23 & 1.7784 & 2.58 & 1.9267 & 1.60 & 0.0001 & \begin{tabular}{|l|}
1.43 \\
\end{tabular} & \begin{tabular}{|l|}
0.2667 \\
\end{tabular} & 1.60 & 0.0000 & 0.00 & 0.0000 & 0.00 & 0.0000 & 0.00 & 0.0000 \\
\hline 53 & 3.04 & \begin{tabular}{|l|}
0.1531 \\
\end{tabular} & 2.93 & 1.1548 & 3.12 & 1.3483 & 1.60 & 0.0000 & \begin{tabular}{|l|}
1.59 \\
\end{tabular} & \begin{tabular}{|l|}
0.0086 \\
\end{tabular} & 1.60 & 0.0000 & 0.00 & 0.0000 & 0.00 & 0.0000 & 0.00 & 0.0000 \\
\hline 54 & 0.44 & \begin{tabular}{|l|}
0.0004 \\
\end{tabular} & 0.45 & 0.0190 & 0.43 & 0.0004 & 0.45 & 0.0004 & \begin{tabular}{|l|}
0.46 \\
\end{tabular} & \begin{tabular}{|l|}
0.0208 \\
\end{tabular} & 0.45 & 0.0004 & 0.00 & 0.0000 & 0.00 & 0.0000 & 0.00 & 0.0000 \\
\hline
\end{tabular}


Conforme visualizando na Tabela 7.4, verificou-se dispersão para os três algoritmos, mesmo que em diferentes ordens de grandeza. Os resultados da calibração dos coeficientes de qualidade da água, nos 54 trechos simulados, mostraram que o AG apresentou menor desvio padrão em todos os trechos quando comparados com o PSO e o DE, isto justifica a menor dispersão obtida para o perfil de qualidade para as 50 simulações. Os algoritmos PSO e DE apresentaram maior dispersão das variáveis no espaço de busca.

A Figura 7.9 e Figura 7.10 apresentam os resultados do perfil de qualidade da água para os parâmetros DBO e OD, respectivamente. A simulação da qualidade foi realizada com os valores médios de ka, Kd e ks obtidos a partir das 50 simulações para cada trecho do Rio Atibaia.

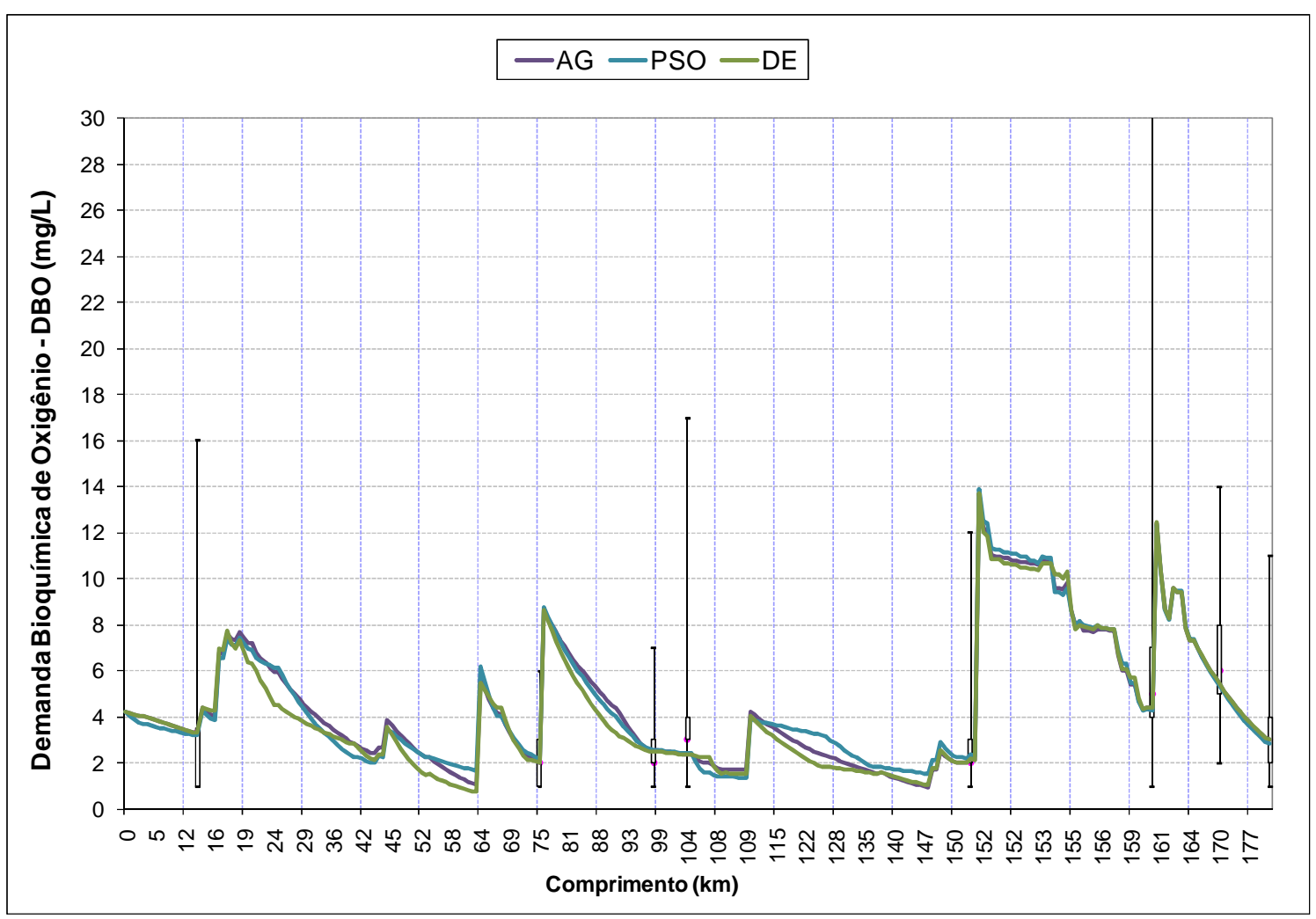

Figura 7.9 - Perfil de DBO para os parâmetros médios obtidos para as 50 simulações com os algoritmos AG, PSO e DE 


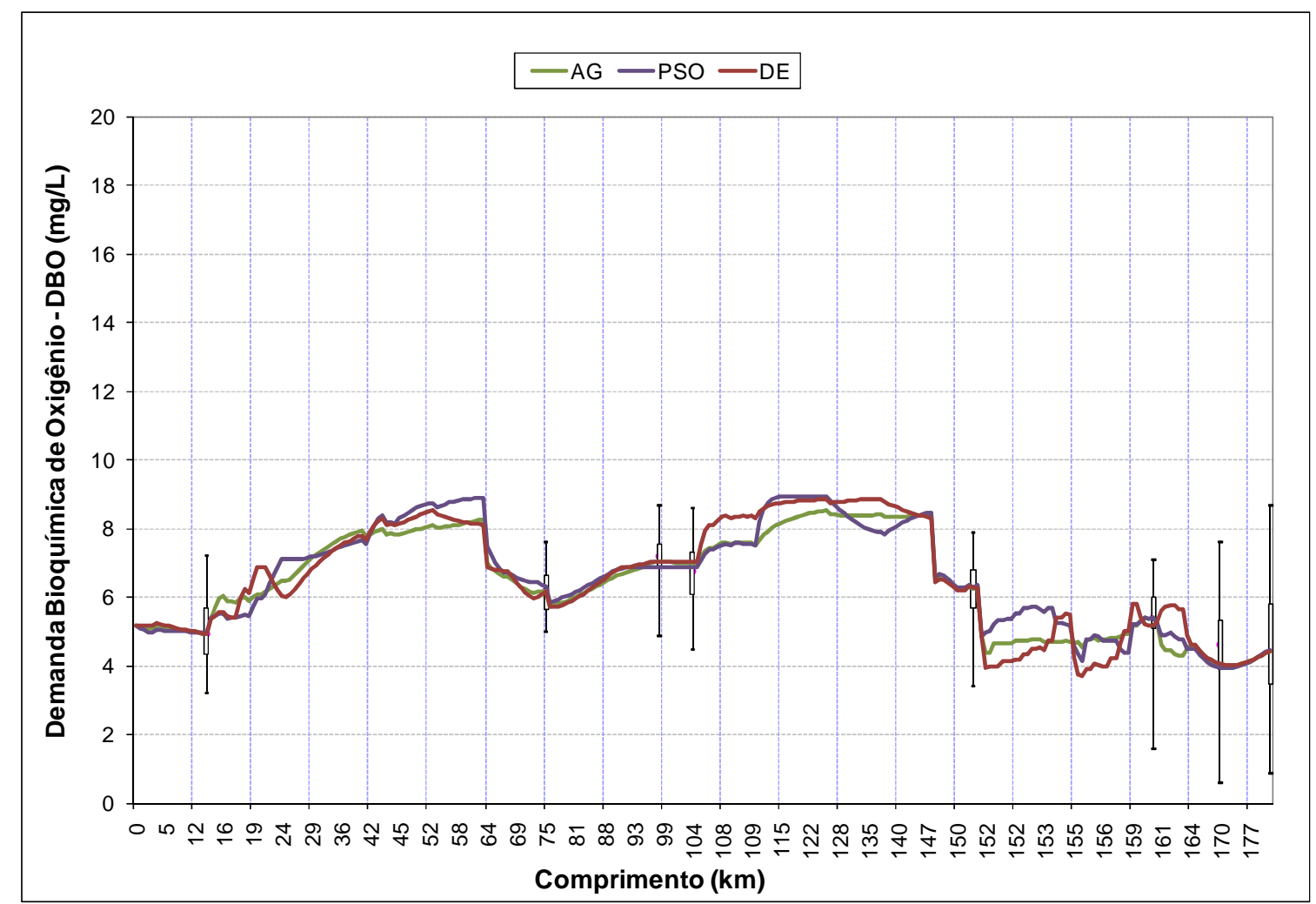

Figura 7.10 - Perfil de OD para os parâmetros médios obtidos para as 50 simulações com os algoritmos AG, PSO e DE

Os perfis de DBO e OD (Figura 7.9 e Figura 7.10) obtidos com os valores médios dos parâmetros apresentaram bom ajuste quando comparados com os valores observados, representados pelos Box-Plots, indicando que a calibração automática pode ser utilizada para calibrar o modelo de qualidade ou ajustar os valores inicias de cada trecho.

A calibração automática é uma ferramenta importante para um SSD, pois este tem entre suas finalidades facilitar o uso das informações existentes, trazendo mais agilidade para as análises.

\subsection{Análise da outorga de efluentes na Bacia do Rio Atibaia}

A outorga de efluentes ainda não é avaliada pela maioria dos órgãos gestores devido a maior complexidade do processo de análise, quando comparado com a outorga quantitativa. $\mathrm{Na}$ análise da outorga de efluentes, não é possível avaliar apenas o balanço hídrico, sendo necessário introduzir as análises qualitativas, envolvendo modelos que simulem a qualidade da água do corpo hídrico.

Uma vez inseridas as análises qualitativas no processo de outorga, além da estruturação de um modelo de qualidade da água, existe a necessidade de se avaliar outros componentes que fazem parte do processo, tais como, o enquadramento dos corpos de 
água, as restrições ambientais regionais para a qualidade dos efluentes, a alocação espacial das cargas poluidoras, as eficiências de tratamento que serão impostas para cada usuário da bacia ou grupos de usuários com mesma finalidade de uso e os custos de tratamento dessas medidas de despoluição. Para que estas análises possam ser realizadas existe a necessidade do estabelecimento de estratégias de outorga, avaliando o impacto de cada uma dessas estratégias no perfil de qualidade da água, assim como o impacto econômico para implementação das medidas de despoluição estabelecidas por estas estratégias.

Os algoritmos evolucionários utilizados neste estudo foram avaliados e comprados entre si através do desempenho para a solução da função objetivo na análise das estratégias para alocação de carga de efluentes, tendo em vista a concessão da outorga de efluentes.

A função objetivo visa minimizar os custos de implantação das estações de tratamento de efluentes, tendo em vista a manutenção da classe de enquadramento e a avaliação das penalidades impostas, tais como, a isonomia entre os usuários, a obediência da Legislação Ambiental e o atendimento das demandas quantitativas (captações).

A vazão de referência utilizada para a análise de outorga quantitativa, como discutido no item 3.2.3, são valores restritivos como a $Q_{7,10}, Q_{95 \%}$ e em alguns casos uma fração destes valores. A utilização de valores restritivos para a análise de outorga de efluentes implica em custos de tratamento de efluentes mais elevados, para manter os limites de qualidade impostos pela classe de enquadramento do corpo d'água.

Neste estudo de caso, a vazão $Q_{95 \%}$ foi adotada por representar uma condição de escassez que possibilita o estudo dos impactos produzidos pelo uso. Menegon (2005) estabeleceu o perfil de vazão para o rio Camanducaia, pertencente à Bacia do Rio Piracicaba, onde concluiu que as vazões no período de estiagem ajustam-se ao perfil da vazão de referência $Q_{95 \%}$. Estas vazões foram estabelecidas através de campanhas de tempo de trânsito no rio. Portanto, a vazão de referência a $Q_{95 \%}$ ajusta-se bem nas condições observadas na região do presente estudo.

Para avaliar as potencialidades do modelo foram simuladas diferentes estratégias de outorga de efluentes, nas quais foram avaliados os perfis de qualidade da água, 0 comprometimento das vazões de diluição, assim como os custos de implantação das medidas de despoluição propostas. Cada estratégia de outorga deverá respeitar diferentes restrições e penalidades impostas à função objetivo.

\subsubsection{Estratégias de outorga 1-Sem Restrições}

A estratégia 1 avalia a outorga de efluentes sem considerar restrições, sejam elas a isonomia entre os usuários e a concentração dos efluentes previstos na Lei Ambiental para 
- Lançamento de Efluentes do Estado de São Paulo. Nesta simulação devem ser respeitadas apenas as restrições de tratamento mínimo e máximo impostas por usuário ou finalidade de uso pelo gestor da bacia, assim como os limites estabelecidos pelo enquadramento dos corpos d'água para cada trecho de rio. A estratégia de outorga 1 é subdividida em estratégia $A$ e $B$, onde na estratégia $A$ o valor da captação não é otimizado, sendo igual à vazão requerida caso exista disponibilidade quantitativa, assim nesta estratégia a captação é um dado de entrada do modelo. Na estratégia $\mathrm{B}$, a demanda (captação) é uma variável decisória e deve ser indicado o limite mínimo e máximo de captação para cada trecho.

Neste estudo de caso os valores adotados foram os seguintes:

- limite mínimo de captação igual a $80 \%$ do valor requerido pelo usuário; e

- limite máximo de captação igual à demanda requerida pelo usuário.

Estes valores são dados de entrada do modelo.

A Figura 7.11 mostra a evolução da função objetivo ao longo das 5000 gerações analisadas na otimização com os algoritmos AG, PSO e DE.

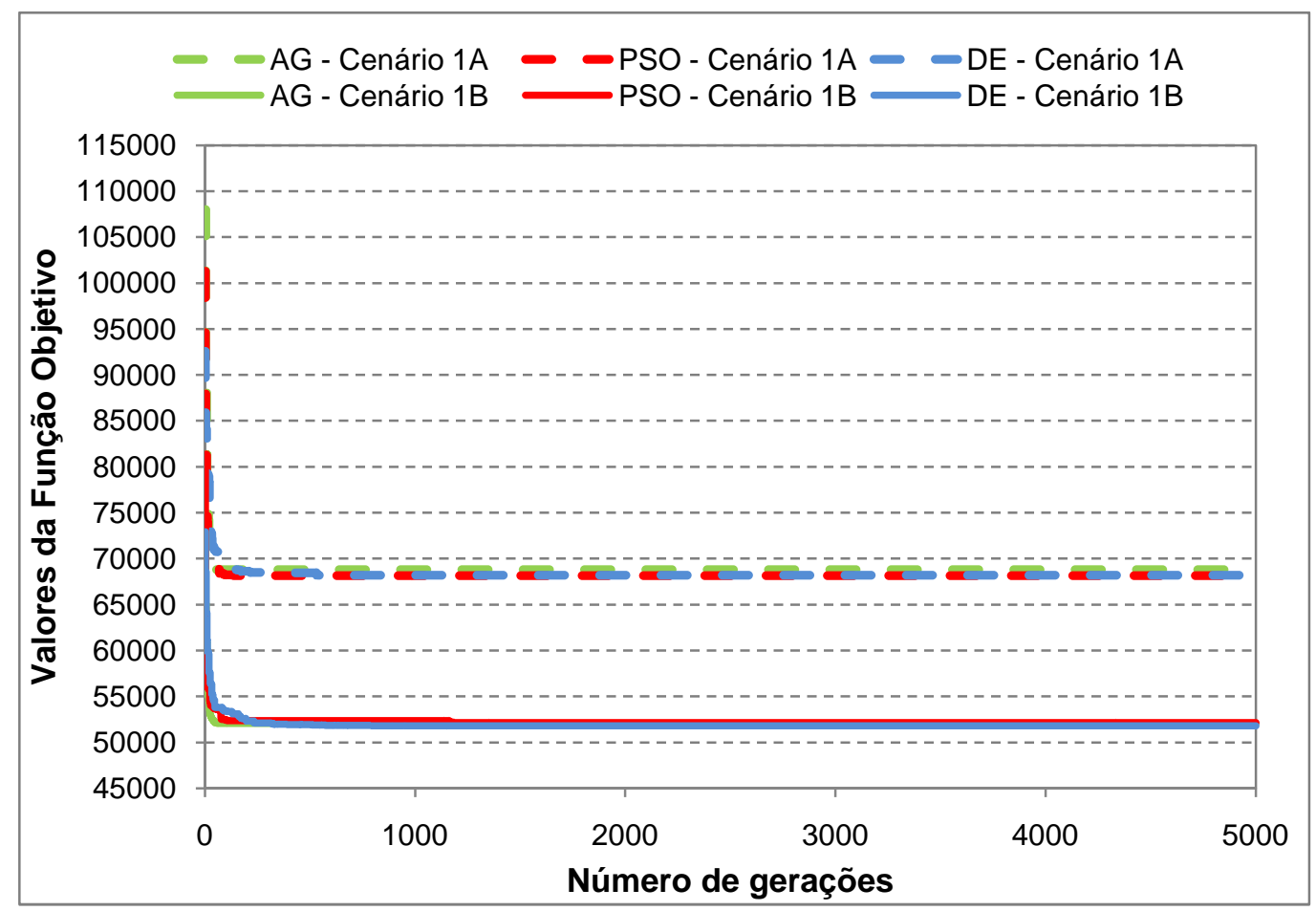

Figura 7.11 - Comportamento da função objetivo para as $\mathbf{5 0 0 0}$ gerações analisadas para estratégia 1 A e B

Observa-se na Figura 7.11 que os três algoritmos obtiveram bom desempenho para a solução da função objetivo após as 5000 gerações impostas como critério de parada do modelo. A figura indica que os valores da função objetivo para a estratégia de outorga $1 \mathrm{~B}$ foram menores que os valores obtidos para a estratégia 1A. Essa diferença é explicada 
pelo fato que na estratégia $1 \mathrm{~A}$ as demandas (vazões da captação) são concedidas em sua totalidade, o que diminui a disponibilidade de água para diluição e, consequentemente, torna-se necessário aumentar os níveis de tratamento de efluentes para manter a qualidade desejada no corpo d'água. Na estratégia 1B as demandas são variáveis, impondo maior grau de liberdade ao otimizador, quando se reduz o volume captado, através do não atendimento das demandas, aumenta-se o volume de água disponível para a diluição de efluentes $e$, consequentemente, reduz-se o custo para o atendimento à classe de enquadramento.

Os valores obtidos para a função objetivo com os três algoritmos são apresentados na Tabela 7.5, onde também são apresentados o custo total das estações de tratamento de efluentes, o déficit total das demandas $\left(\mathrm{m}^{3} / \mathrm{s}\right)$, a vazão de diluição necessária, número de vezes que a Lei Ambiental foi violada e a carga remanescente total em Toneladas de $\mathrm{DBO} /$ dia.

Tabela 7.5- Resultados obtidos para a função objetivo (FO), custo global, vazão de diluição, violação da Lei Ambiental de efluentes e carga total remanescente para AG, PSO e DE na avaliação da alocação de carga no rio Atibaia - Estratégia de Outorga 1

\begin{tabular}{c|c|c|c|c|c|c|c}
\hline \multirow{5}{*}{ Estratégia } & Algoritmo & Valor da FO & $\begin{array}{c}\text { Custo Total } \\
\text { das } \\
\text { Estações de } \\
\text { Tratamento } \\
\mathrm{R} \$ 10^{6}\end{array}$ & $\begin{array}{c}\text { Déficit total } \\
\text { nas } \\
\text { demandas } \\
\left(\mathrm{m}^{3} / \mathrm{s}\right)\end{array}$ & $\begin{array}{c}\text { Vazão } \\
\text { de } \\
\text { Diluição } \\
\left(\mathrm{m}^{3} / \mathrm{s}\right)\end{array}$ & $\begin{array}{c}\mathrm{N}^{\circ} \text { de } \\
\text { violações } \\
\text { da Lei } \\
\text { Ambiental }\end{array}$ & $\begin{array}{c}\text { Remanescente } \\
\text { Toneladas } \\
\text { DBO/dia }\end{array}$ \\
\hline \multirow{3}{*}{$1 \mathrm{~A}$} & $\mathrm{AG}$ & 68791.49 & 68.791 & 0.00 & 44.45 & 7 & 12.77 \\
\cline { 2 - 9 } & $\mathrm{PSO}$ & 68159.01 & 68.159 & 0.00 & 45.81 & 8 & 13.12 \\
\cline { 2 - 8 } & $\mathrm{DE}$ & 68212.70 & 68.213 & 0.00 & 44.78 & 9 & 12.97 \\
\cline { 2 - 8 } & $\mathrm{AG}$ & 52369.09 & 52.072 & 1.77 & 43.19 & 7 & 13.62 \\
\cline { 2 - 8 } & $\mathrm{PSO}$ & 52617.99 & 52.091 & 1.93 & 45.50 & 7 & 13.62 \\
\hline
\end{tabular}

O algoritmo DE apresentou os melhores resultados em valores globais da função objetivo, mas quando se avalia o valor de custo global de tratamento dos efluentes observase que o DE apresentou melhor resultado para a estratégia 1A e o AG para a estratégia 1B. Estes resultados foram obtidos avaliando a melhor solução para cada algoritmo após 10 simulações. Na mesma tabela também observa-se os déficits de demandas e o número de vezes que a Lei Ambiental foi violada. Os resultados obtidos com os três algoritmos são satisfatórios: para a estratégia $1 \mathrm{~A}$ a não ocorrência de déficits de demandas se deve ao fato que neste cenário a demanda não é uma variável otimizada pelos algoritmos, sendo esta sempre atendida caso exista disponibilidade hídrica no trecho. As violações da legislação ambiental podem ser explicadas pelo fato de que não foram impostas penalidades à função objetivo para o descumprimento da Legislação, assim, não é exigida a obediência da 
Legislação Ambiental para todos os efluentes lançados ao longo do rio. O limite da classe de enquadramento (classe 2) não foi violado em nenhum dos trechos, o perfil de DBO permaneceu sempre abaixo de $5 \mathrm{mg} / \mathrm{L}$ de DBO.

Destaca-se que para a estratégia 1B os três algoritmos consideraram déficits de demandas, buscando a minimização dos custos das medidas de despoluição. Na Tabela 7.6 são apresentados os valores de atendimento às demandas, obtidos com os três algoritmos analisados. Os déficits totais de demandas vaiaram entre 1,77 e 1,93 m³/s.

Tabela 7.6- Atendimento às demandas no Rio Atibaia - Estratégia de Outorga 1B

\begin{tabular}{c|c|c|c|c|c}
\hline \multirow{2}{*}{ Estratégia } & Algoritmo & $\begin{array}{c}\text { Demanda } \\
\text { Total } \\
\text { Requerida } \\
\left(\mathrm{m}^{3} / \mathrm{s}\right)\end{array}$ & $\begin{array}{c}\text { Déficit total } \\
\text { nas } \\
\text { demandas } \\
\left(\mathrm{m}^{3} / \mathrm{s}\right)\end{array}$ & $\begin{array}{c}\mathrm{N}^{0} \text { de } \\
\text { demandas } \\
\text { com déficit }\end{array}$ & $\begin{array}{c}\mathrm{N}^{0} \text { de demandas com } \\
\text { déficit superior a 80\% da } \\
\text { Demanda Requerida }\end{array}$ \\
\hline \multirow{3}{*}{$1 \mathrm{~B}$} & $\mathrm{AG}$ & 13.80 & 1.77 & 12 & 0 \\
\cline { 2 - 6 } & $\mathrm{PSO}$ & 13.80 & 1.93 & 24 & 0 \\
\cline { 2 - 6 } & $\mathrm{DE}$ & 13.80 & 1.87 & 19 & 0 \\
\hline
\end{tabular}

A Tabela 7.6 indica que os algoritmos não atenderam todas as demandas consuntivas buscando minimizar os custos das medidas de despoluição, mas ao mesmo tempo, não permitiram déficits maiores que o estipulado para a bacia, neste caso $20 \%$ da demanda requerida pelo usuário. Isto se deve à restrição imposta, onde o limite inferior para a demanda é de $80 \%$ do valor solicitado. Este valor de $80 \%$ não é um valor fixo e foi adotado para este estudo de caso, pois é um dado de entrada do modelo.

A vazão de diluição não foi considerada de forma direta na função objetivo, no entanto, ao avaliar os resultados obtidos nestas simulações foi possível analisar que alterando a alocação das cargas, com o objetivo de minimizar os custos das medidas de despoluição, a vazão necessária para diluir os efluentes também sofre alteração.

A Figura 7.12 e a Figura 7.13 mostram o perfil de DBO e OD obtidos com a otimização dos três algoritmos evolucionários analisados para as estratégias de outorga $1 \mathrm{~A}$ e $1 \mathrm{~B}$, respectivamente. O perfil de qualidade para as duas estratégias mostrou que os limites estabelecidos pela classe de enquadramento foram obedecidos pelos três algoritmos. 


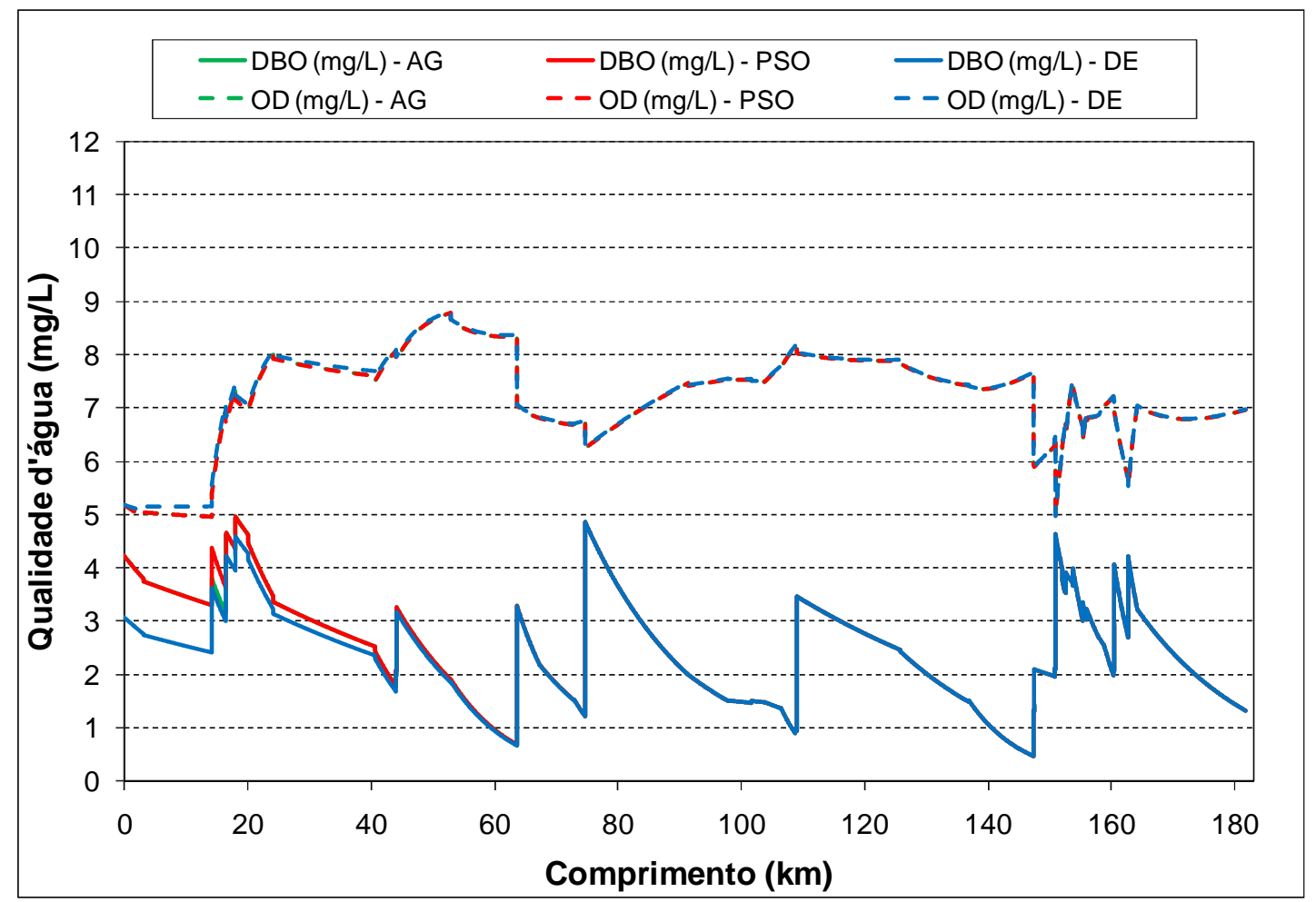

Figura 7.12 - Perfil de OD e DBO para os algoritmo AG, PSO e DE otimizando a estratégia 1A

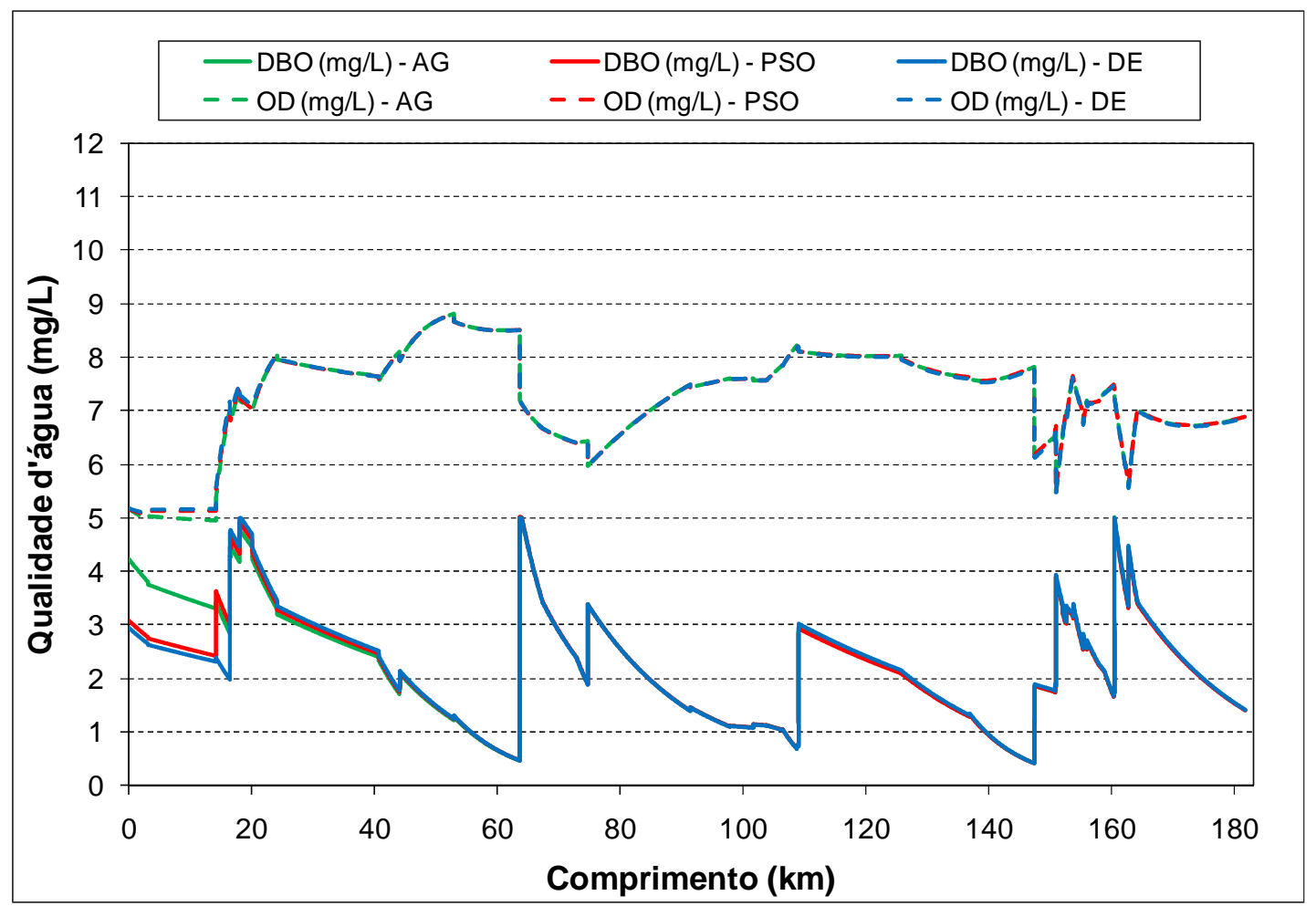

Figura 7.13 - Perfil de OD e DBO para os algoritmo AG, PSO e DE otimizando a estratégia 1B

A Figura 7.14 e a Figura 7.15 indicam o resultado da otimização com o algoritmo AG para as estratégias $1 \mathrm{~A}$ e $1 \mathrm{~B}$, respectivamente. As Figuras apresentam em formato de linhas os perfis de OD, DBO e da vazão nos trechos, no formato de barras podem ser visualizadas 
as vazões necessárias para diluir os efluentes nos pontos de lançamento. Pode-se observar que nos trechos onde o OD e a DBO aproximam-se dos valores limites, estipulados pela classe do rio, a vazão de diluição utiliza, praticamente, iguala-se a vazão total do rio no trecho correspondente para diluir o efluente. Um exemplo disto é indicado nos kilômetros 18 e 74 da Figura 7.14 e nos kilômetros 63 e 163 da Figura 7.15 .

$\mathrm{Na}$ estratégia $1 \mathrm{~A}$, as demandas são atendidas em sua totalidade, assim sendo, a uma redução na água disponível para diluir os efluentes, o que torna necessária a aplicação de maiores índices de tratamento aos efluentes para manutenção dos padrões de qualidade no rio. Diferentemente do que ocorre na estratégia $1 \mathrm{~A}$, a estratégia $1 \mathrm{~B}$ permite 0 não atendimento total das demandas requeridas, o que disponibiliza água para a diluição dos efluentes.

Para a estratégia 1A a vazão de diluição é tanto maior quando menor for o custo de investimento nas estações de tratamento de efluentes. Na estratégia 1B o comportamento da vazão de diluição é similar ao visto na estratégia $1 \mathrm{~A}$, porem existe a necessidade de avaliar os valores de vazão remanescente no rio que podem sofrer alteração devido ao não atendimento das demandas consuntivas.

A Figura 7.16 e a Figura 7.17 mostram os resultados da otimização utilizando o algoritmo PSO para as estratégias $1 \mathrm{~A}$ e $1 \mathrm{~B}$, respectivamente, onde o comportamento foi semelhante ao encontrado com o algoritmo AG, anteriormente discutido.

Os perfis de OD, DBO, vazão nos trechos e a vazão necessária para diluir os efluentes, tendo em vista o atendimento da classe do rio, resultante da otimização pelo algoritmo DE, podem ser visualizados na Figura 7.18 e na Figura 7.19. O comportamento do algoritmo DE foi semelhante ao AG e ao PSO, para as estratégias $1 \mathrm{~A}$ e $1 \mathrm{~B}$.

Nas duas estratégias, $1 \mathrm{~A}$ e 1B, os algoritmos AG, PSO e DE buscaram maximizar a vazão de diluição, usando toda a capacidade de assimilação do corpo receptor.

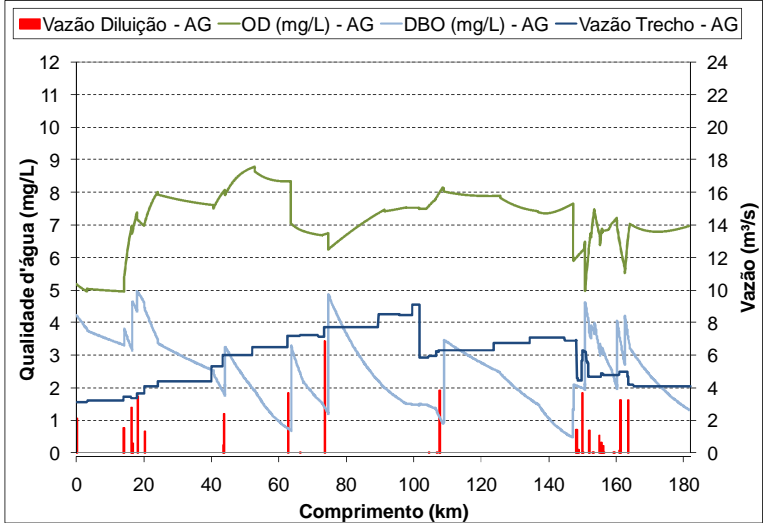

Figura 7.14 - Perfil de OD e DBO, vazão do trecho e vazão de diluição para estratégia $1 \mathrm{~A}$ obtido com o AG

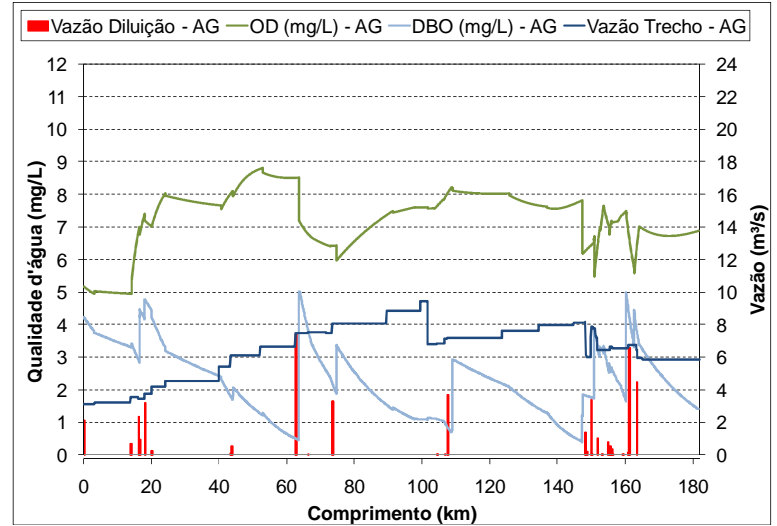

Figura 7.15 - Perfil de OD e DBO, vazão do trecho e vazão de diluição para estratégia 1B obtido com o AG 


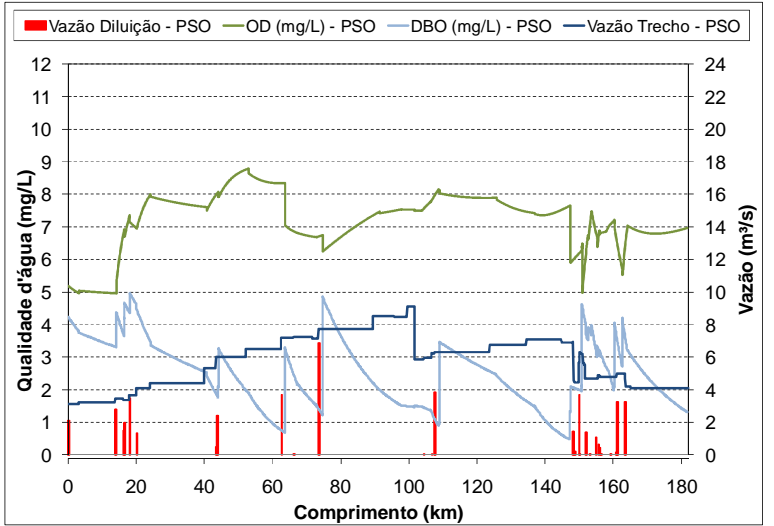

Figura 7.16 - Perfil de OD e DBO, vazão do trecho e vazão de diluição para estratégia $1 \mathrm{~A}$ obtido com o PSO

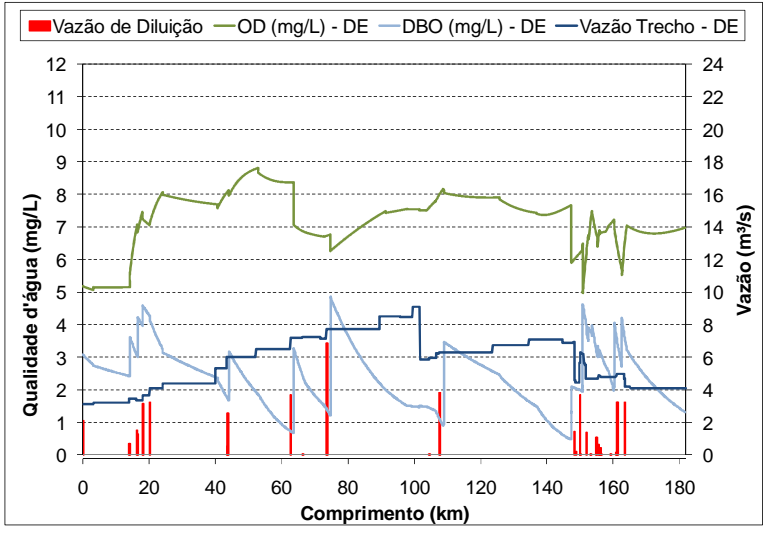

Figura 7.18 - Perfil de OD e DBO, vazão do trecho e vazão de diluição para estratégia $1 \mathrm{~A}$ obtido com o DE

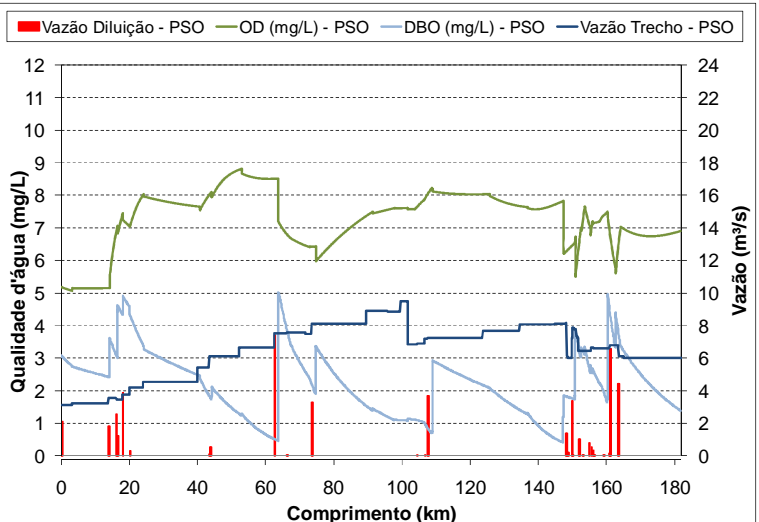

Figura 7.17 - Perfil de OD e DBO, vazão do trecho e vazão de diluição para estratégia 1B obtido com o PSO

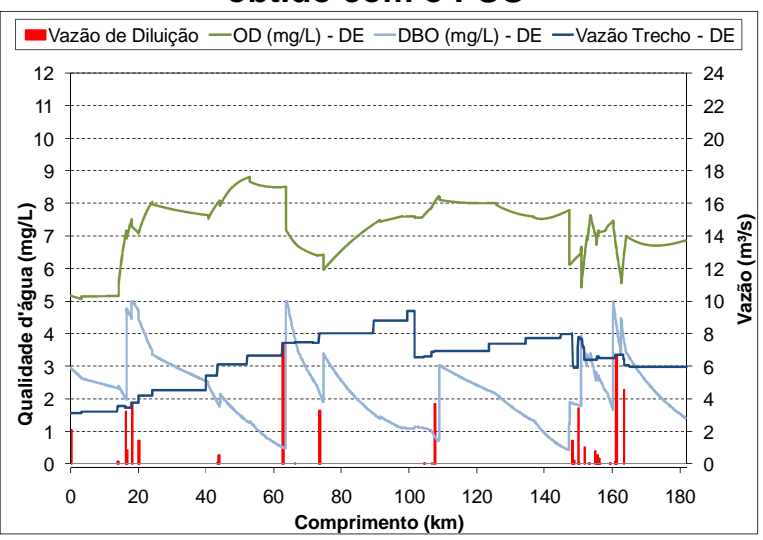

Figura 7.19 - Perfil de OD e DBO, vazão do trecho e vazão de diluição para estratégia 1B obtido com o DE

Como discutido na definição das estratégias 1A e 1B, a principal diferença entre as mesmas é a liberação da vazão de diluição em função do não atendimento das vazões requeridas (Estratégia 1B). O aumento da disponibilidade de vazão no corpo d'água para diluir os efluentes acarretará na redução dos custos de tratamento de efluentes.

A vazão utilizada para diluir os efluentes nas estratégias 1A e 1B variaram de 44,45 $\mathrm{m}^{3} / \mathrm{s}$ a $45,81 \mathrm{~m}^{3} / \mathrm{s}$ e de $43,19 \mathrm{~m}^{3} / \mathrm{s}$ a $45,50 \mathrm{~m}^{3} / \mathrm{s}$, respectivamente, estes valores foram obtidos pelo somatório das vazões representadas pelas barras das duas estratégias nas Figura 7.14 a Figura 7.19. Observou-se que a vazão de diluição sofre grande influência da vazão e concentração disponível no rio no ponto de lançamento.

A Figura 7.20 e a Figura 7.21 reproduzem este fato, as quais apresentam o custo das medidas de despoluição adotadas para cada trecho e o custo acumulado ao longo do rio para cada algoritmo nas estratégias de outorga $1 \mathrm{~A}$ e $1 \mathrm{~B}$, respectivamente. $\mathrm{O}$ custo total acumulado na estratégia $1 \mathrm{~A}$, aproximadamente $\mathrm{R} \$ 68$ milhões para os três algoritmos, é maior do que o observado na estratégia $1 \mathrm{~B}$, aproximadamente $\mathrm{R} \$ 52$ milhões para os três algoritmos, a qual apresenta maior vazão disponível no corpo d'água para diluir os efluentes e com isso é possível uma flexibilização na adoção dos níveis de tratamento. 


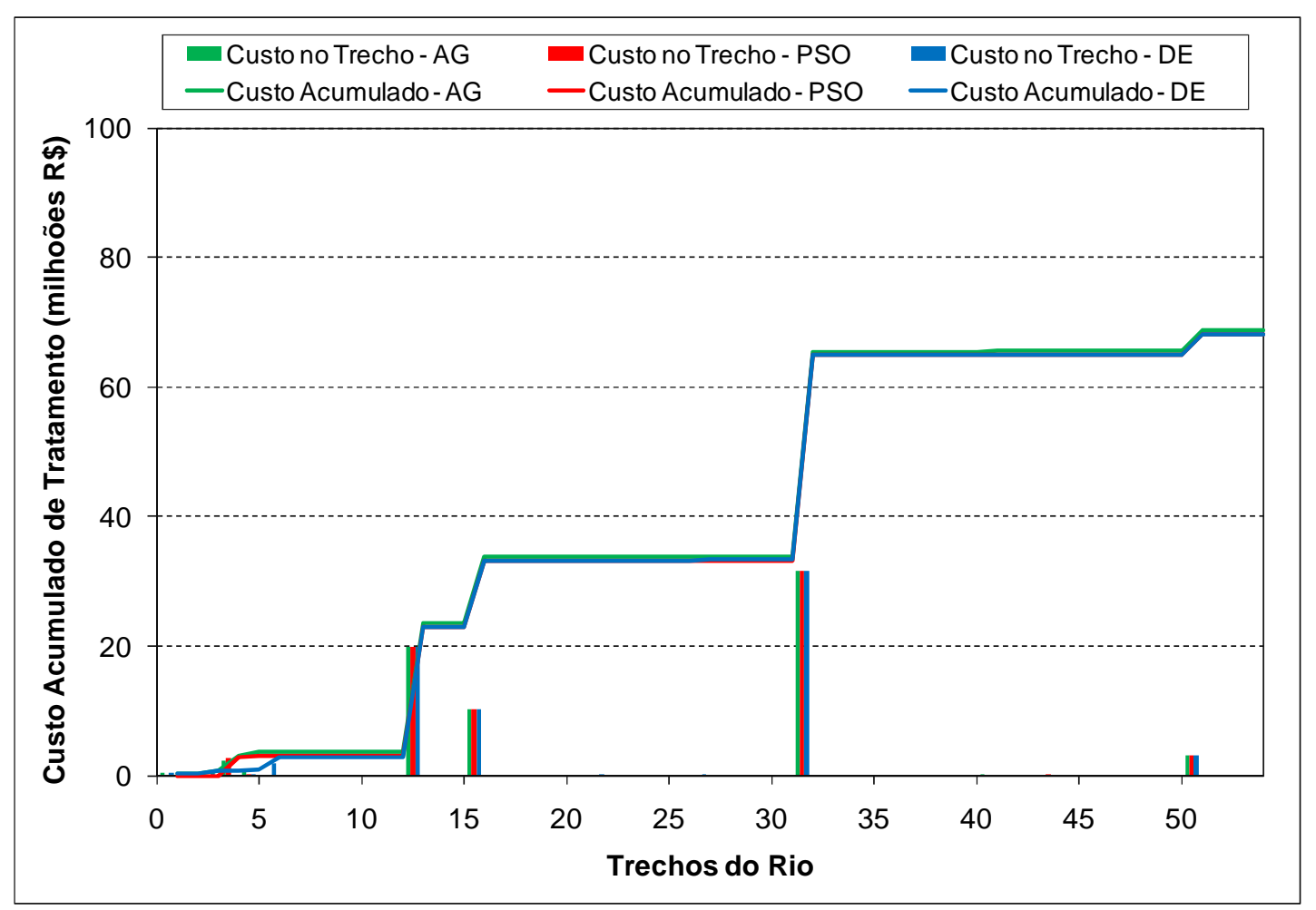

Figura 7.20 - Distribuição dos custos das medidas de despoluição ao longo dos trechos e acumulada para a estratégia de outorga $1 \mathrm{~A}$

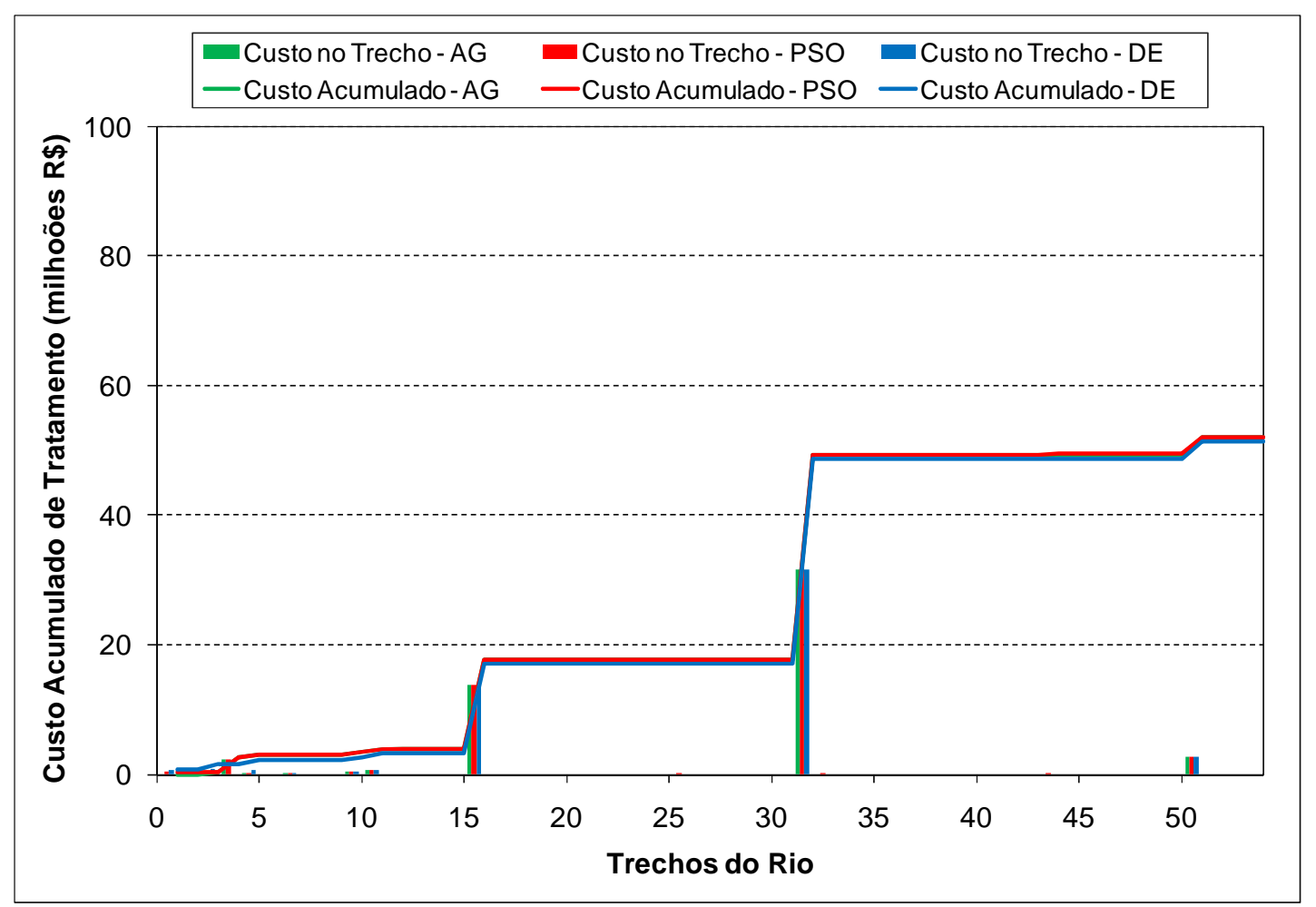

Figura 7.21 - Distribuição dos custos das medidas de despoluição ao longo dos trechos e acumulada para a estratégia de outorga 1 B

$\mathrm{Na}$ análise das estratégias de outorga $1 \mathrm{~A}$ e $1 \mathrm{~B}$, é possível observar que os três algoritmos, AG, PSO e DE obtiveram respostas muito próximas quanto ao custo global das 
medidas de despoluição (Figura 7.20 e Figura 7.21) e quando ao perfil de qualidade da água (Figura 7.14 a Figura 7.19). Estes resultados permitem concluir que os três algoritmos apresentam bom desempenho para a solução da função objetivo. Outra característica interessante observada na análise das estratégias 1A e 1B é que os algoritmos concentraram os maiores investimentos em medidas de despoluição nos mesmos trechos de rio, indicando os pontos mais vulneráveis do sistema e, possivelmente, estes são os pontos onde os investimentos emergências devem ser aplicados.

No entanto, é importante considerar que apesar da estratégia B ter apresentado um custo global reduzido para o tratamento dos efluentes, existem os custos relativos ao não atendimento total das demandas, o qual incide sobre o usuário do sistema e, desta forma, poderá ocorrer um impacto econômico para a bacia como um todo.

Os resultados obtidos na análise da estratégia 1 mostram que a outorga de efluentes é um processo complexo e deve ser amplamente discutida, pois o simples fato de alterar o cenário de captação (demandas consuntivas) produz alteração do custo global das medidas de despoluição. No entanto, também destaca-se que a diminuição dos valores captados não altera os pontos críticos existentes da bacia hidrográfica, pois os investimentos em medidas de despoluição foram localizados nos mesmo trechos do rio, para as duas estratégias.

Os algoritmos buscaram a maximização da vazão de diluição para as estratégias $1 \mathrm{~A}$ e 1B, ou seja, aplicaram as técnicas de tratamento visando o menor custo e com isso, comprometendo o volume remanescente no rio para a diluição dos efluentes.

\subsubsection{Estratégias de outorga 2 - Obedece a Lei Ambiental}

A estratégia de outorga 2 avalia a outorga de efluentes considerando as restrições de concentração e eficiência de tratamento dos efluentes previstos na Lei Ambiental do Estado de São Paulo para o lançamento em corpos da água. Para esta simulação devem ser respeitadas as restrições impostas ao modelo, sendo elas o limite mínimo e máximo de tratamento imposto para cada usuário e o limite máximo permitido pela legislação ambiental para os efluentes.

A Legislação Ambiental de São Paulo restringe os lançamento de efluentes em 60 $\mathrm{mg} / \mathrm{L}$ de $\mathrm{DBO}$ ou tratamento mínimo de $80 \%$ de remoção de carga. Assim como a estratégia de outorga 1, a estratégia 2 foi subdividida em estratégia $A$ e B. Na estratégia $2 A$ o valor da captação não é otimizado e na estratégia 2B a demanda (captação) é uma variável decisória, para esta estratégia o usuário também deve indicar o limite mínimo e máximo de captação em cada trecho, sendo adotado para atendimento mínimo das demandas consuntivas o valor de $80 \%$. 
A Figura 7.22 mostra a evolução da função objetivo ao longo das 5000 gerações analisadas na otimização dos algoritmos AG, PSO e DE.

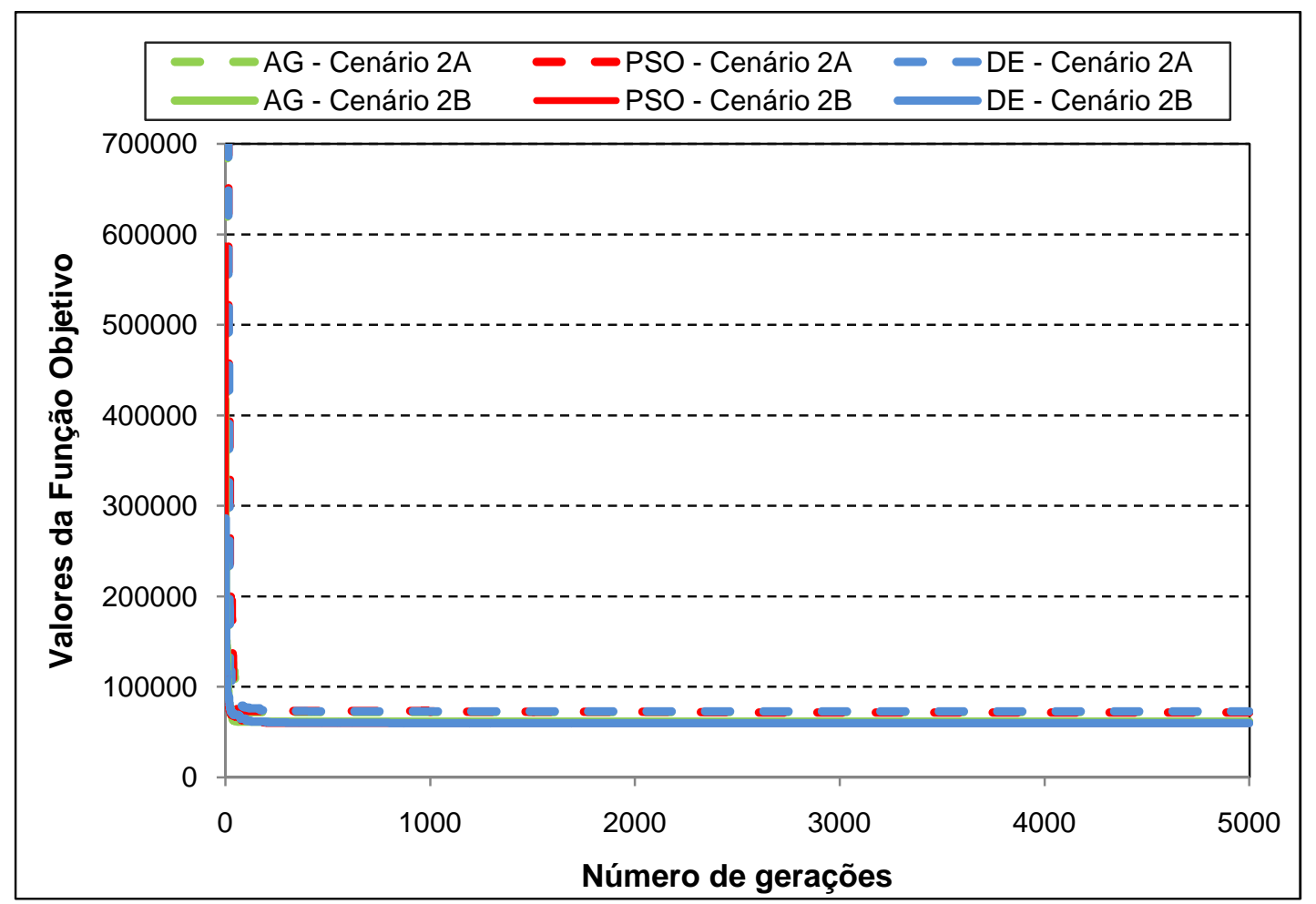

Figura 7.22 - Comportamento da função objetivo para as 5000 gerações analisadas para estratégia 2 A e B

Conforme indicado na Figura 7.22, a função objetivo apresentou bom desempenho para a solução da função objetivo após as 5000 gerações quando comparados os três algoritmos analisados. Assim como na estratégia de outorga 1, os valores da função objetivo para a estratégia de outorga $2 \mathrm{~B}$ foram menores que os valores obtidos para a estratégia $2 \mathrm{~A}$. A diferença entre as estratégias $2 \mathrm{~A}$ e $2 \mathrm{~B}$ é menor que 0 valor encontrado na estratégia 1 , esta diferença é explicada pelo fato que a estratégia 2 é mais restritiva devidos às imposições de obediência da legislação ambiental para o lançamento de efluentes, o que torna o aumento da disponibilidade hídrica para a diluição de efluentes menos impactante na FO.

$\mathrm{Na}$ Tabela 7.7, são apresentados os valores da FO, o custo total das estações de tratamento de efluentes, o déficit das demandas $\left(\mathrm{m}^{3} / \mathrm{s}\right)$, o número de demandas com déficit obtido com cada algoritmo e o número de vezes em que a DBO do efluente está em desacordo com a Lei Ambiental. 
Tabela 7.7- Resultados obtidos para a função objetivo (FO), custo global, vazão de diluição, violação da Lei Ambiental de efluentes e carga total remanescente para AG, PSO e DE na avaliação da alocação de carga no rio Atibaia - Estratégia de Outorga 2

\begin{tabular}{c|c|c|c|c|c|c|c}
\hline \multirow{5}{*}{ Estratégia } & Algoritmo & Valor da FO & $\begin{array}{c}\text { Custo Total } \\
\text { das } \\
\text { Estações de } \\
\text { Tratamento } \\
\mathrm{R} \$ 10^{6}\end{array}$ & $\begin{array}{c}\text { Déficit total } \\
\text { nas } \\
\text { demandas } \\
\left(\mathrm{m}^{3} / \mathrm{s}\right)\end{array}$ & $\begin{array}{c}\text { Vazão } \\
\text { de } \\
\text { Diluição } \\
\mathrm{m}^{3} / \mathrm{s}\end{array}$ & $\begin{array}{c}\mathrm{N}^{\circ} \text { de } \\
\text { violações } \\
\text { da Lei } \\
\text { Ambiental }\end{array}$ & $\begin{array}{c}\text { Remanescente } \\
\text { Toneladas } \\
\text { DBO/dia }\end{array}$ \\
\hline \multirow{3}{*}{$2 \mathrm{~A}$} & $\mathrm{AG}$ & 72084.16 & 72.08 & 0.00 & 22.55 & 0 & 9.14 \\
\cline { 2 - 9 } & $\mathrm{PSO}$ & 71848.51 & 71.85 & 0.00 & 22.72 & 0 & 9.20 \\
\cline { 2 - 9 } & $\mathrm{DE}$ & 72877.62 & 72.88 & 0.00 & 22.44 & 0 & 9.12 \\
\cline { 2 - 9 } & $\mathrm{AG}$ & 61576.81 & 58.97 & 1.74 & 29.75 & 0 & 11.36 \\
\cline { 2 - 9 } & $\mathrm{PSO}$ & 59436.99 & 58.87 & 1.01 & 30.89 & 0 & 11.47 \\
\hline
\end{tabular}

O comportamento dos valores da função objetivo foi semelhante ao comportamento da função objetivo da estratégia 1 , onde os valores da FO para a estratégia de outorga $2 \mathrm{~B}$ foram menores que os valores obtidos para a estratégia $2 \mathrm{~A}$. $\mathrm{Na}$ análise da estratégia 2 , foi observado que ao reduzir o volume captado, esse volume é disponibilizado para diluir os efluentes e, com isso, diminui o custo global das medidas de despoluição.

$\mathrm{Na}$ Tabela 7.7, observa-se os déficits de demandas, presentes apenas na estratégia 2B, os quais foram permitidos, e a não violação da Lei Ambiental para as duas estratégias adotadas, o que indica a obediência das restrições impostas à FO.

Este comportamento indicou que os três algoritmos mostraram-se capazes de otimizar o sistema, obedecendo as restrições impostas e atendendo as penalidades aplicadas à FO.

$\mathrm{Na}$ Tabela 7.8, são apresentados os valores de atendimento às demandas, obtidos com os três algoritmos analisados para a estratégia $2 \mathrm{~B}$, onde a demanda é uma variável a ser otimizada. Observa-se que o algoritmo respeitou as penalidades impostas à função objetivo, e todas as demandas foram atendidas com no mínimo $80 \%$ do total requerido. Os déficits totais de demandas vaiaram entre 1,01 a 1,74 m³/s entre os três algoritmos.

Tabela 7.8- Atendimento às demandas no Rio Atibaia - Estratégia de Outorga 2B

\begin{tabular}{c|c|c|c|c|c}
\hline \multirow{2}{*}{ Estratégia } & Algoritmo & $\begin{array}{c}\text { Demanda Total } \\
\text { Requerida } \\
\left(\mathrm{m}^{3} / \mathrm{s}\right)\end{array}$ & $\begin{array}{c}\text { Déficit total nas } \\
\text { demandas } \\
\left(\mathrm{m}^{3} / \mathrm{s}\right)\end{array}$ & $\begin{array}{c}\mathrm{N}^{0} \text { de } \\
\text { demandas } \\
\text { com déficit }\end{array}$ & $\begin{array}{c}\mathrm{N}^{0} \text { de demandas com } \\
\text { déficit superior a 80\% } \\
\text { da Demanda } \\
\text { Requerida }\end{array}$ \\
\hline \multirow{3}{*}{$2 \mathrm{~B}$} & $\mathrm{AG}$ & 13.80 & 1.74 & 26 & 0 \\
\cline { 2 - 6 } & $\mathrm{PSO}$ & 13.80 & 1.01 & 21 & 0 \\
\cline { 2 - 6 } & $\mathrm{DE}$ & 13.80 & 1.48 & 23 & 0 \\
\hline
\end{tabular}


A Figura 7.23 e Figura 7.24 mostram o perfil de DBO e OD obtidos com a otimização dos três algoritmos evolucionários analisados para as estratégias de outorga $2 \mathrm{~A}$ e $2 \mathrm{~B}$. $\mathrm{Na}$ análise do perfil, observa-se que os limites estabelecidos pela classe de enquadramento foram obedecidos pelos três algoritmos.

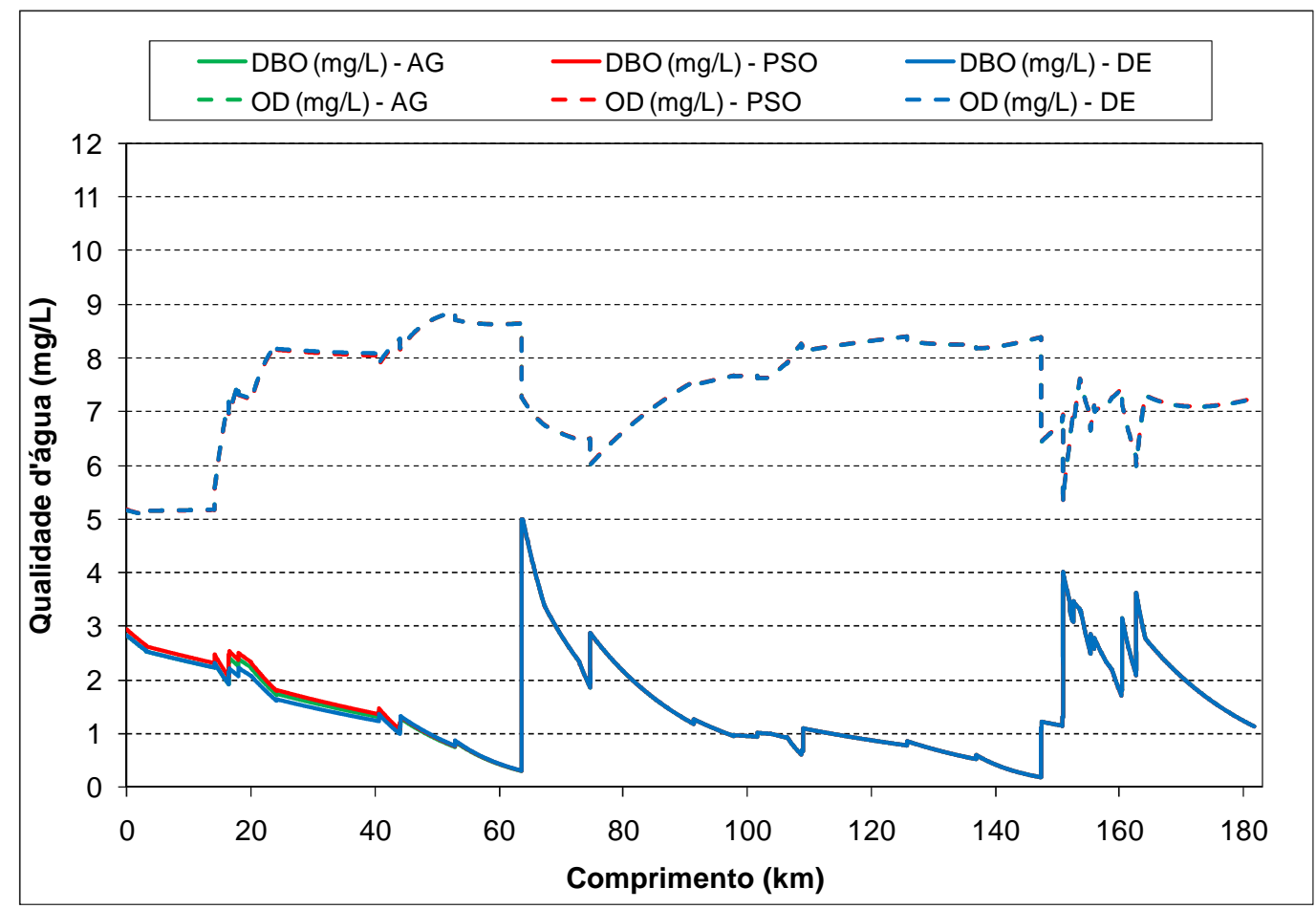

Figura 7.23 - Perfil de OD e DBO para os algoritmo AG, PSO e DE otimizando a estratégia 2 A

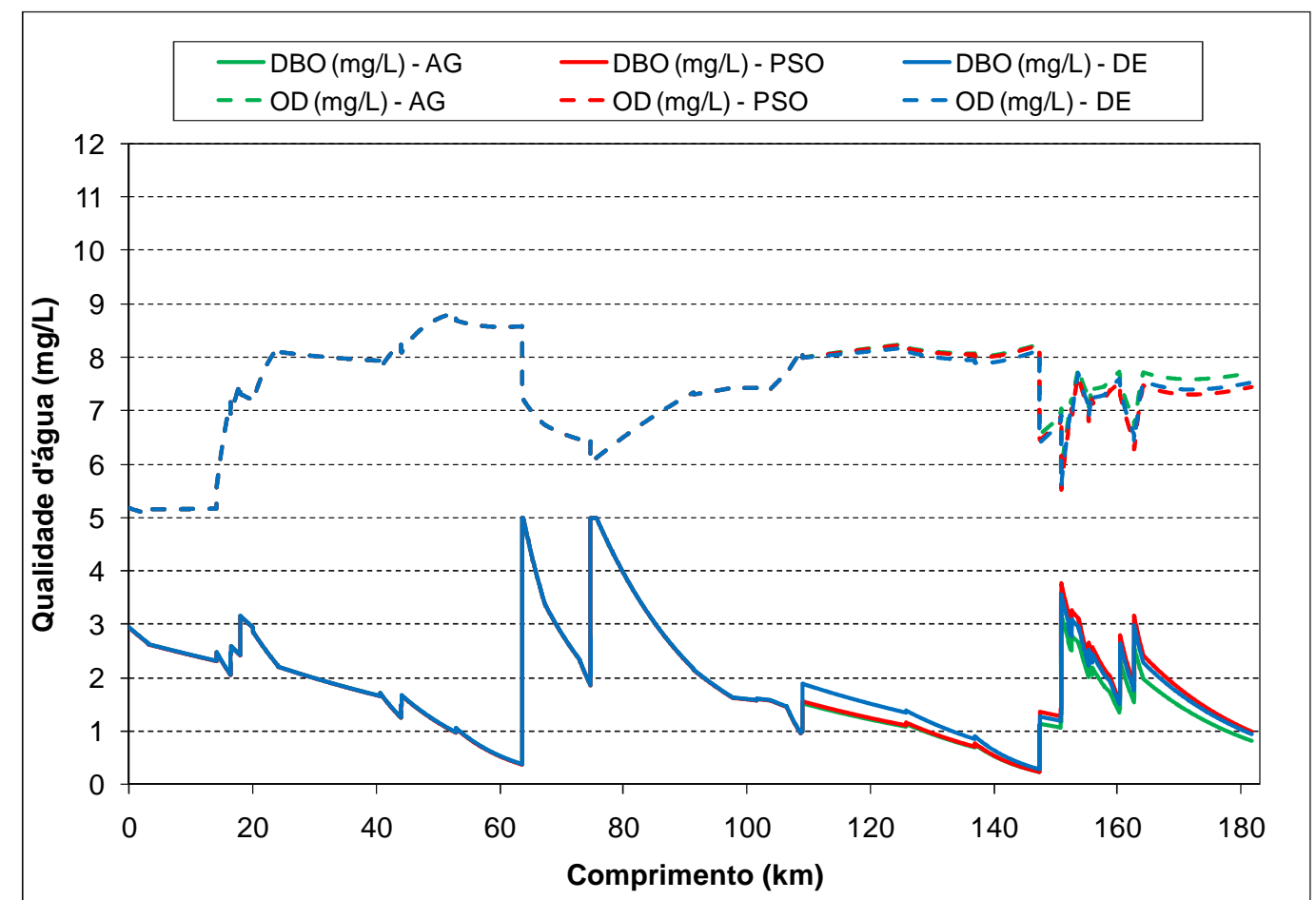

Figura 7.24 - Perfil de OD e DBO para os algoritmo AG, PSO e DE otimizando a estratégia 2 B 
A Figura 7.25 e a Figura 7.26 ilustram o perfil do resultado otimizado dos algoritmos AG para a estratégia $2 \mathrm{~A}$ e $2 \mathrm{~B}$, respectivamente. Da mesma forma que apresentado na estratégia 1, as Figuras apresentam os perfis de OD, DBO, a vazão nos trechos e as vazões necessárias para diluir os efluentes nos pontos de lançamento.

$\mathrm{Na}$ estratégia $2 \mathrm{~A}$, as demandas são atendidas em sua totalidade, o que reduz a disponibilidade de água para diluir os efluentes, tendo em vista a manutenção dos padrões de qualidade no rio. A estratégia $2 \mathrm{~B}$, o não atendimento total das demandas disponibiliza água para a diluição dos efluentes.

A Figura 7.27 e a Figura 7.28 apresentam o perfil da qualidade e das vazões nos trechos e de diluição nos pontos de lançamento obtidos a partir do algoritmo PSO, para as estratégias $2 \mathrm{~A}$ e $2 \mathrm{~B}$, respectivamente.

Os resultados obtidos, para a qualidade da água e das vazões ao longo do rio Atibaia, através da otimização do sistema com o algoritmo DE podem ser observados na Figura 7.29 e na Figura 7.30 para a estratégia 2A e 2B, respectivamente.

Destaca-se que os algoritmos AG, PSO e DE buscaram maximizar a vazão de diluição, usando a capacidade de assimilação do corpo receptor nas estratégias $2 \mathrm{~A}$ e $2 \mathrm{~B}$. Assim como na estratégia 1, observa-se que nos trechos onde o OD e a DBO aproximaramse do valor limite da classe, a vazão de diluição utiliza a vazão total do trecho.

A vazão utilizada para diluir os efluentes nas estratégias $2 A$ e $2 B$ variaram de 22,44 $\mathrm{m}^{3} / \mathrm{s}$ a $22,72 \mathrm{~m}^{3} / \mathrm{s}$ e de $29,75 \mathrm{~m}^{3} / \mathrm{s}$ a $30,95 \mathrm{~m}^{3} / \mathrm{s}$, respectivamente, estes valores foram obtidos pelo somatório das vazões representadas pelas barras das duas estratégias nas Figura 7.25 a Figura 7.30. Observa-se que a vazão de diluição sofre grande influência da vazão e concentração disponível no rio no ponto de lançamento.

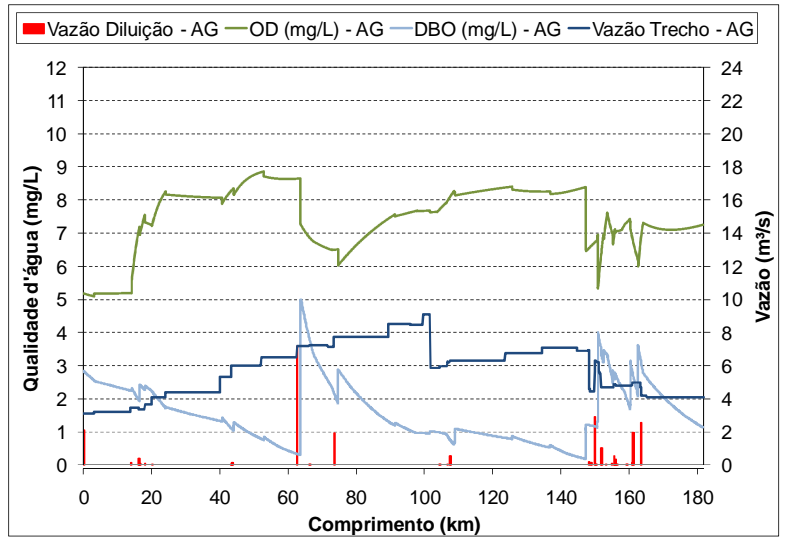

Figura 7.25 - Perfil de OD e DBO, vazão do trecho e vazão de diluição para estratégia $2 \mathrm{~A}$ obtido com o AG

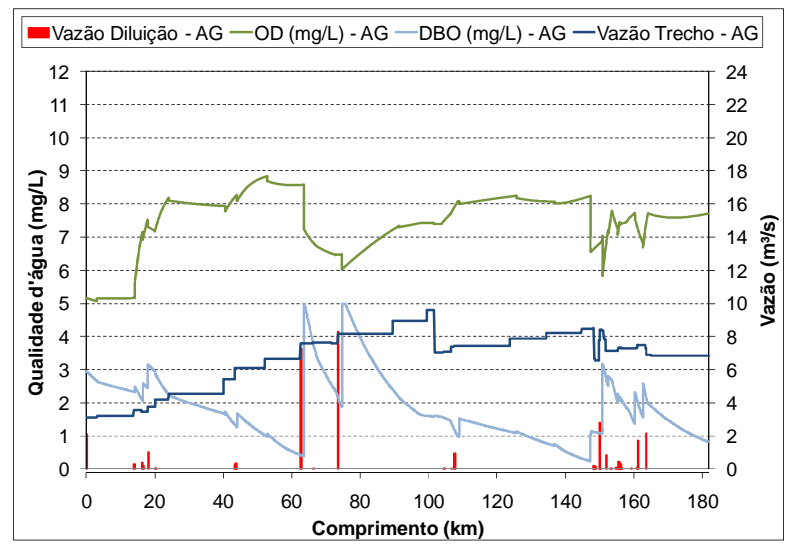

Figura 7.26 - Perfil de OD e DBO, vazão do trecho e vazão de diluição para estratégia 2 B obtido com o AG 


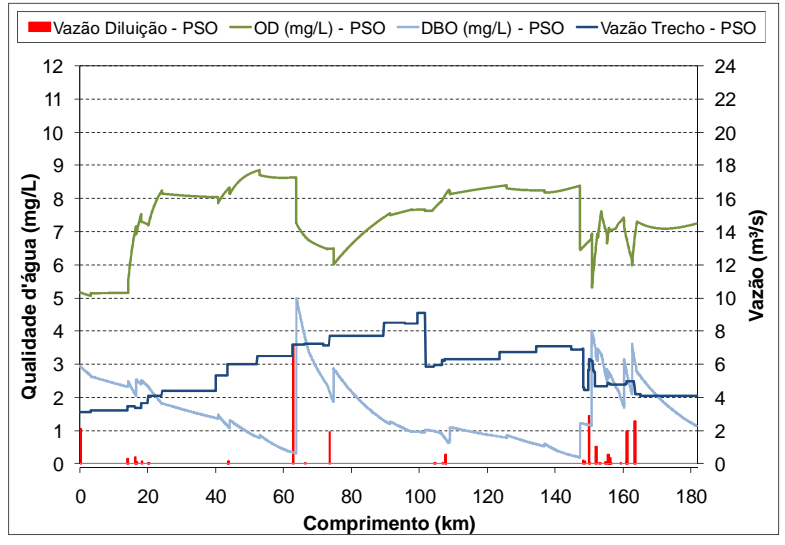

Figura 7.27 - Perfil de OD e DBO, vazão do trecho e vazão de diluição para estratégia $2 \mathrm{~A}$ obtido com o PSO

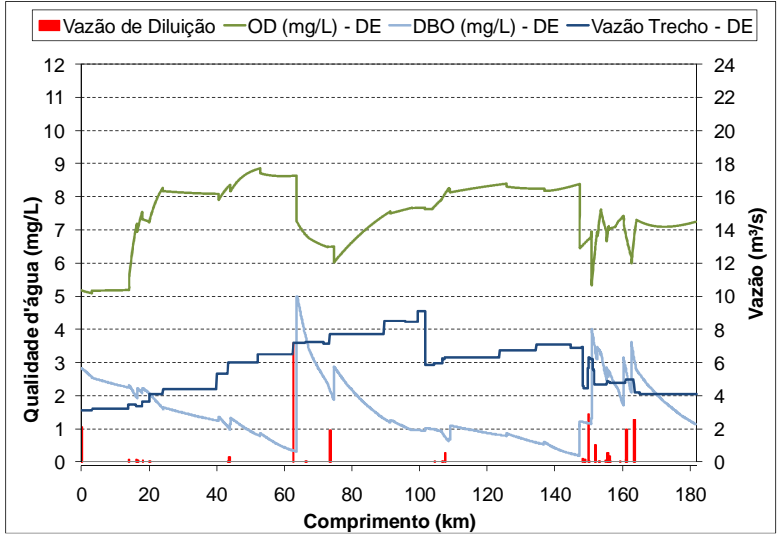

Figura 7.29 - Perfil de OD e DBO, vazão do trecho e vazão de diluição para estratégia 2 A obtido com o DE

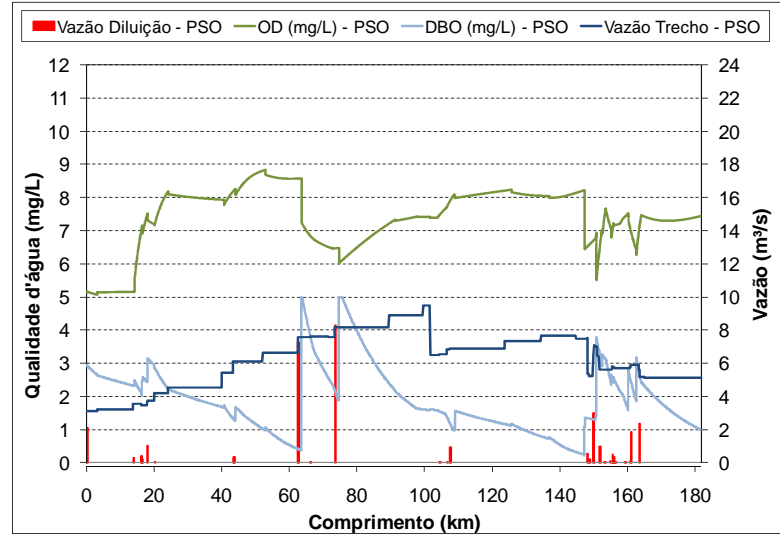

Figura 7.28 - Perfil de OD e DBO, vazão do trecho e vazão de diluição para estratégia 2 B obtido com o PSO

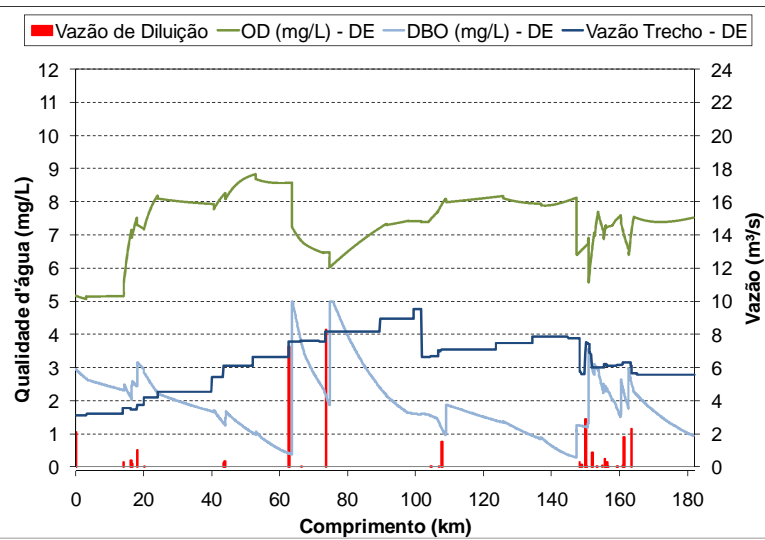

Figura 7.30 - Perfil de OD e DBO, vazão do trecho e vazão de diluição para estratégia $2 \mathrm{~B}$ obtido com o DE

Comportamento semelhante ao obtido na estratégia 1 para o custo global das estratégias $1 \mathrm{~A}$ e $1 \mathrm{~B}$ foi obtido para a estratégia 2. A maior disponibilidade de água para diluição dos efluentes observada na estratégia $2 \mathrm{~B}$ a torna mais econômica, em termos de custo global total. A Figura 7.31 a e Figura 7.32 ilustram este comportamento, nas quais podem ser observados os custos das medidas de despoluição adotadas em cada trecho e o custo acumulado ao longo do rio para cada algoritmo nas estratégias de outorga 2A, e 2B, respectivamente. Os obtidos para o custo foi aproximadamente $R \$ 72$ milhões para os três algoritmos na estratégia $2 \mathrm{~A}$ e $\mathrm{R} \$ 59$ milhões para a estratégia $2 \mathrm{~B}$. 


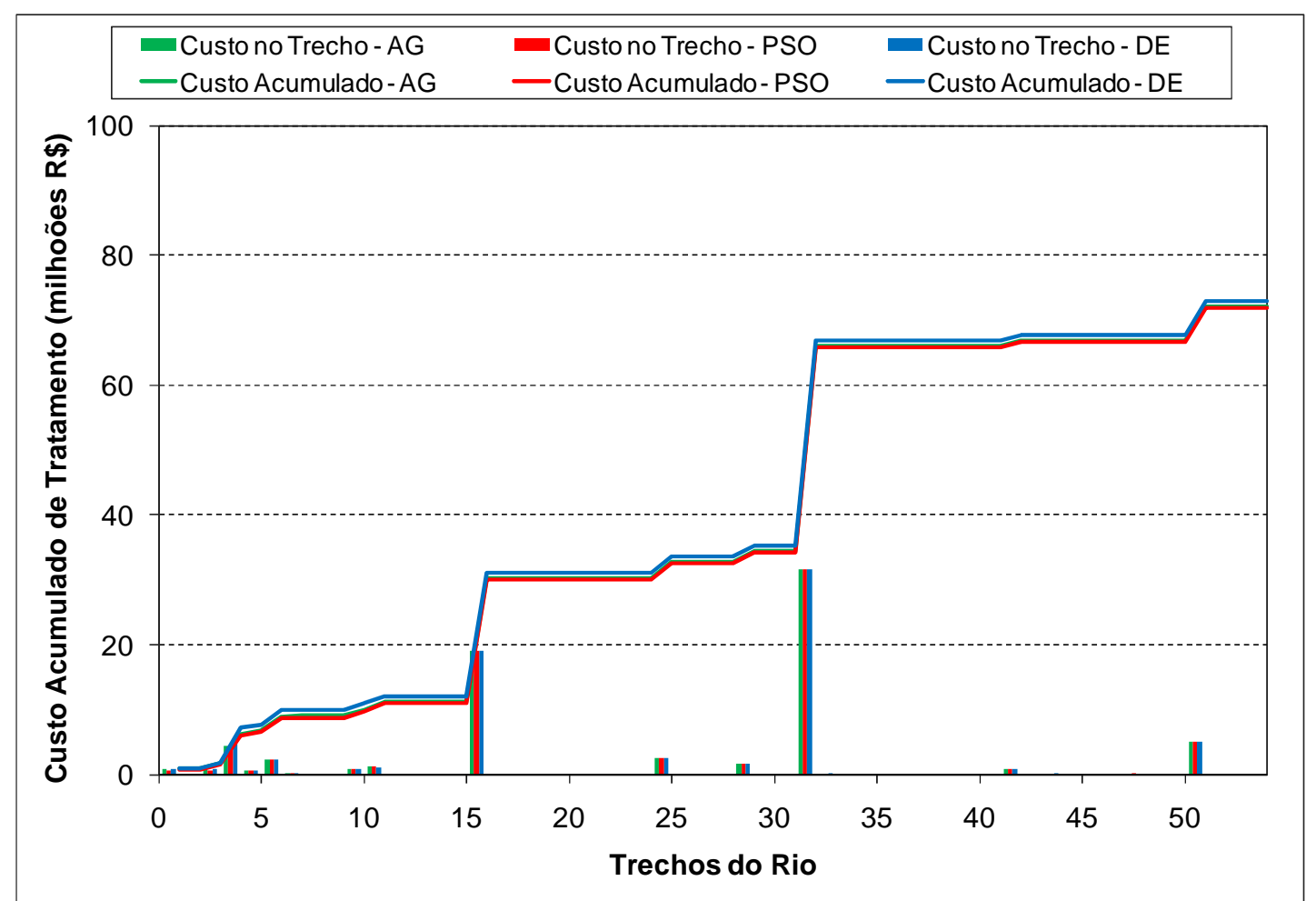

Figura 7.31 - Distribuição dos custos das medidas de despoluição ao longo dos trechos e acumulada para a estratégia de outorga $2 \mathrm{~A}$

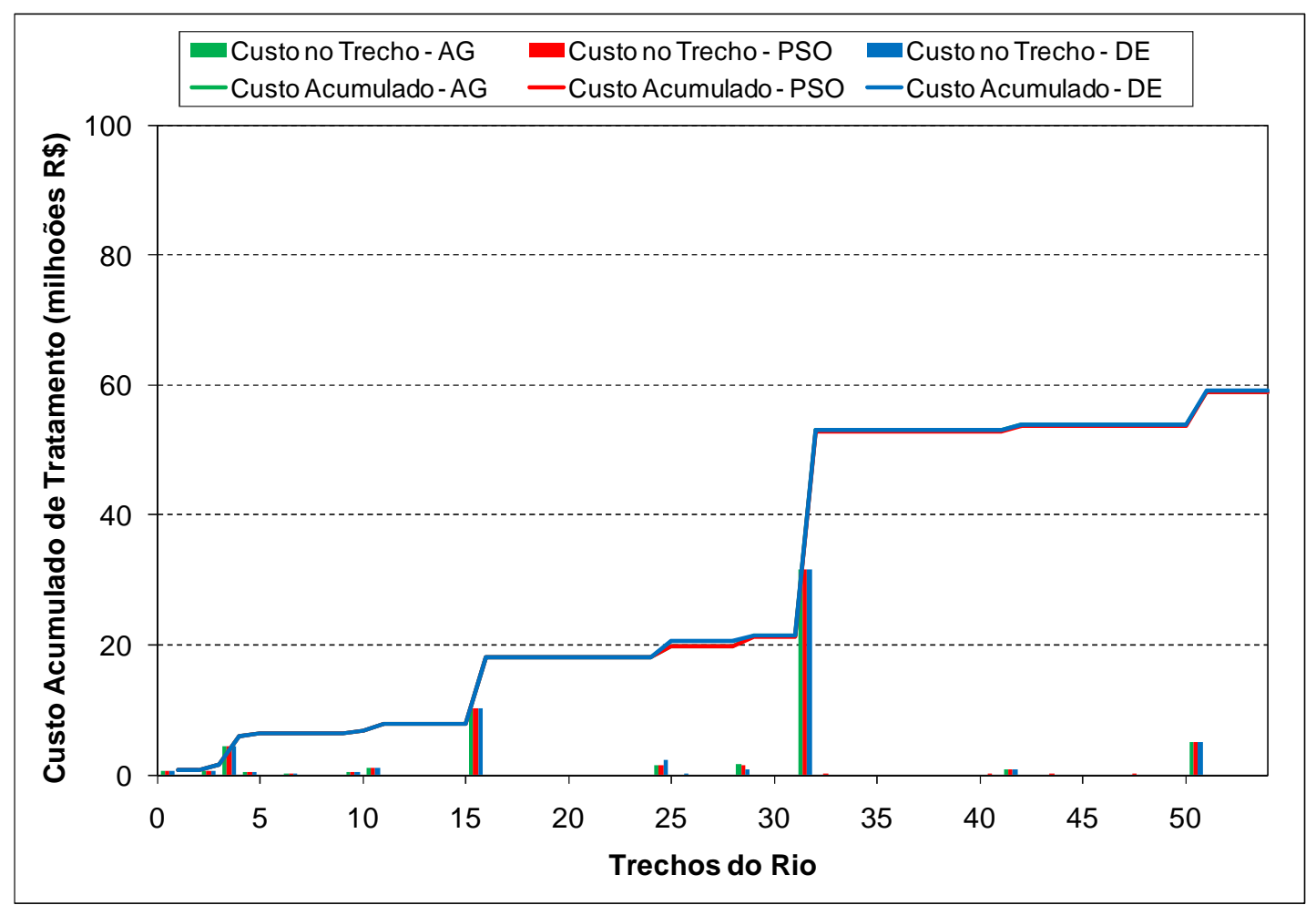

Figura 7.32 - Distribuição dos custos das medidas de despoluição ao longo dos trechos e acumulada para a estratégia de outorga 2B

$\mathrm{Na}$ análise da estratégia de outorga 2 observou-se que os três algoritmos obtiveram respostas muito próximas, quanto ao custo global das medidas de despoluição e quando ao 
perfil de qualidade da água, assim como apresentado na estratégia 1. Mesmo considerando a restrição da Legislação Ambiental, a estratégia 2 apresentou a mesma distribuição dos investimentos que na estratégia 1, onde os investimentos concentraram-se nos trechos mais vulneráveis, trechos 16 e 32, com menor capacidade de assimilação ou com maiores concentrações de poluentes.

\subsubsection{Estratégias de outorga 3-Obedece a isonomia entre os usuários}

A estratégia de outorga 3 avalia a outorga de efluentes considerando a isonomia entre os usuários da bacia hidrográfica, onde os usuários com mesma finalidade de uso devem obedecer as mesmas eficiências de tratamento de efluentes. Nesta simulação, devem ser respeitadas as restrições impostas ao modelo, sendo elas o limite mínimo e máximo de tratamento imposto por finalidade de uso. A estratégia de outorga 3 foi subdividida em estratégia $A$ e $B$, considerando as demandas como um dado de entrada do modelo ou como uma variável do modelo, respectivamente.

Destaca-se que a restrição imposta à função objetivo para a isonomia entre os usuários impõe tratamento a usuários localizados em pontos da bacia com maior disponibilidade de água para a diluição. Ao estabelecer um nível de tratamento mais elevado para os usuários localizados em regiões com maior problema de qualidade da água, ou menor vazão disponível para diluição, o critério estabelece o mesmo nível de tratamento para aqueles localizados em outras regiões da bacia onde a qualidade da água é menos crítica.

A Figura 7.33 indica o bom desempenho dos algoritmos, quando comparados entre si, para a solução da função objetivo após as 5000 gerações impostas como critério de parada do modelo quando comparados os algoritmos AG, PSO e DE. 


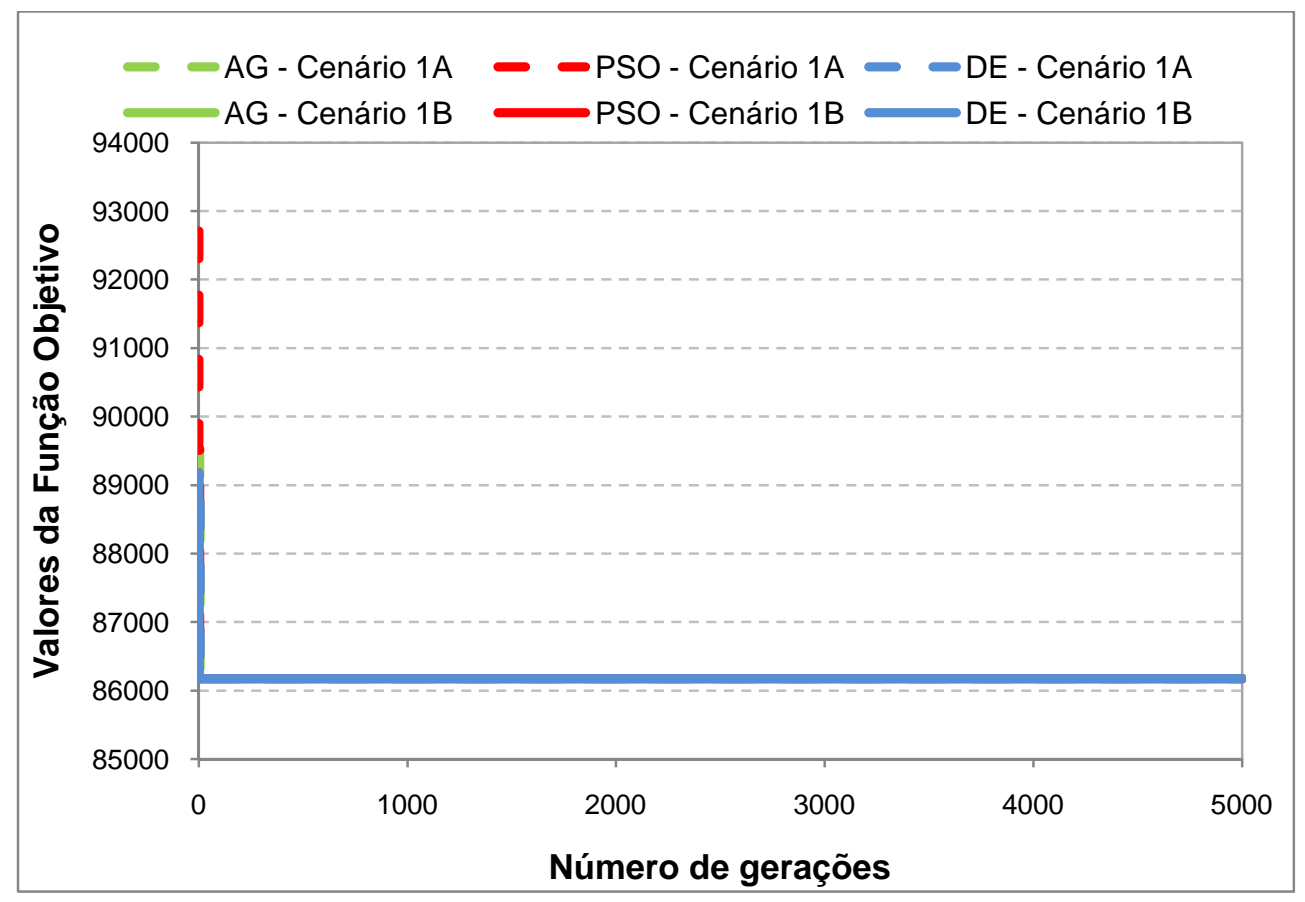

Figura 7.33 - Comportamento da função objetivo para as 5000 gerações analisadas para estratégia 3 A e B

$\mathrm{Na}$ análise da função objetivo, para a estratégia 3, nota-se que os três algoritmos obtiveram bom desempenho para a solução da função objetivo após as 5000 gerações, atingindo a mesma solução. Diferente do ocorrido nas estratégias de outorga 1 e 2, os valores da função objetivo para a estratégia de outorga 3A e 3B foram iguais. Este resultado pode ser explicado pelo grau de restrição imposto pela estratégia, no caso a isonomia entre os usuários. Esta estratégia impõe tratamentos mais elevados, devidos suas restrições, o que torna o aumento da disponibilidade hídrica para a diluição de efluentes insignificante na redução de custos de implementação das estações de tratamento de efluentes.

A Tabela 7.9 apresenta os valores da FO, do custo total das estações de tratamento de efluentes, do déficit total das demandas $\left(\mathrm{m}^{3} / \mathrm{s}\right)$, da vazão total de diluição $\left(\mathrm{m}^{3} / \mathrm{s}\right)$ obtido para cada algoritmo, do número de vezes que a Lei Ambiental não foi obedecida e da carga remanescente total em Toneladas de DBO/Dia.

Tabela 7.9- Resultados obtidos para a função objetivo (FO), custo global, vazão de diluição, violação da Lei Ambiental de efluentes e carga total remanescente para AG, PSO e DE na avaliação da alocação de carga no rio Atibaia - Estratégia de Outorga 3

\begin{tabular}{c|c|c|c|c|c|c|c}
\hline \multirow{2}{*}{ Estratégia } & Algoritmo & Valor da FO & $\begin{array}{c}\text { Custo Total } \\
\text { das } \\
\text { Estações de } \\
\text { Tratamento } \\
\mathrm{R} \$ 10^{6}\end{array}$ & $\begin{array}{c}\text { Déficit total } \\
\text { nas } \\
\text { demandas } \\
\left(\mathrm{m}^{3} / \mathrm{s}\right)\end{array}$ & $\begin{array}{c}\text { Vazão } \\
\text { de } \\
\text { Diluição } \\
\mathrm{m}^{3} / \mathrm{s}\end{array}$ & $\begin{array}{c}\mathrm{N}^{0} \text { de } \\
\text { violações } \\
\text { da Lei } \\
\text { Ambiental }\end{array}$ & $\begin{array}{c}\text { Carga } \\
\text { Remanescente } \\
\text { Toneladas } \\
\text { DBO/dia }\end{array}$ \\
\hline \multirow{3}{*}{$3 \mathrm{~A}$} & $\mathrm{AG}$ & 86179.66 & 86.18 & 0.00 & 24.06 & 10 & 8.20 \\
\cline { 2 - 8 } & $\mathrm{PSO}$ & 86179.66 & 86.18 & 0.00 & 24.06 & 10 & 8.20 \\
\cline { 2 - 8 } & $\mathrm{DE}$ & 86179.66 & 86.18 & 0.00 & 24.06 & 10 & 8.20 \\
\hline
\end{tabular}




\begin{tabular}{c|c|c|c|c|c|c|c}
\hline Estratégia & Algoritmo & Valor da FO & $\begin{array}{c}\text { Custo Total } \\
\text { das } \\
\text { Estações de } \\
\text { Tratamento } \\
\mathrm{R} \$ 10^{6}\end{array}$ & $\begin{array}{c}\text { Déficit total } \\
\text { nas } \\
\text { demandas } \\
\left(\mathrm{m}^{3} / \mathrm{s}\right)\end{array}$ & $\begin{array}{c}\text { Vazão } \\
\text { de } \\
\text { Diluição } \\
\mathrm{m}^{3} / \mathrm{s}\end{array}$ & $\begin{array}{c}\mathrm{N}^{0} \text { de } \\
\text { violações } \\
\text { da Lei } \\
\text { Ambiental }\end{array}$ & $\begin{array}{c}\text { Carga } \\
\text { Remanescente } \\
\text { Toneladas } \\
\text { DBO/dia }\end{array}$ \\
\hline \multirow{3}{*}{$3 \mathrm{~B}$} & $\mathrm{AG}$ & 86179.66 & 86.18 & 0.00 & 24.06 & 10 & 8.20 \\
\cline { 2 - 8 } & $\mathrm{PSO}$ & 86179.66 & 86.18 & 0.00 & 24.06 & 10 & 8.20 \\
\cline { 2 - 8 } & $\mathrm{DE}$ & 86179.66 & 86.18 & 0.00 & 24.06 & 10 & 8.20 \\
\hline
\end{tabular}

O número elevado de violações à legislação ambiental se explica pelo fato que nesta estratégia não existe penalização na função objetivo pelo descumprimento da Lei Ambiental de lançamento de efluentes. Cabe destacar que esta violação não afeta os padrões de qualidade da água estabelecidos pelo enquadramento dos corpos hídricos.

Outro resultado obtido com os três algoritmos, tanto para a estratégia 3A como para a 3B, foi que as duas estratégias atenderam as demandas em sua totalidade. Apesar da estratégia 3B permitir a ocorrência de déficits de demanda, os mesmos não ocorreram devido aos tratamentos mais restritivos impostos a todos os usuários de mesma finalidade de uso, isonomia, o que disponibilizou mais água para as captações.

A Figura 7.34 e a Figura 7.35 mostram o perfil de DBO e OD obtidos para a otimização das estratégias de outorga $3 \mathrm{~A}$ e $3 \mathrm{~B}$, para os três algoritmos evolucionários analisados neste estudo. Devido às restrições impostas por esta estratégia, o parâmetro de DBO apresenta valores inferiores aos limites estipulados pela classe de enquadramento, classe 2, onde o limite para o parâmetro de DBO é de $5 \mathrm{mg} / \mathrm{L}$.

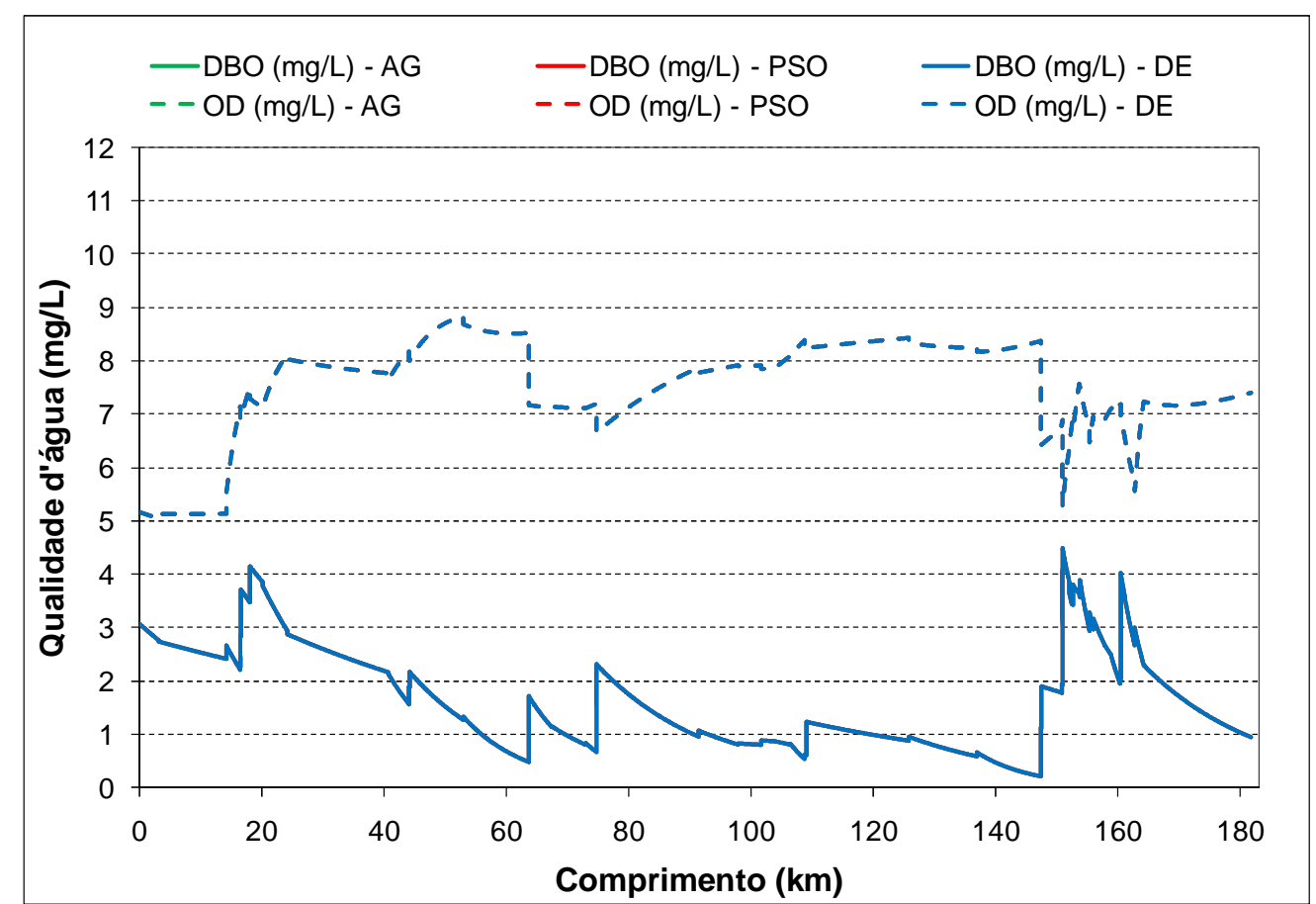

Figura 7.34 - Perfil de OD e DBO para os algoritmo AG, PSO e DE otimizando a estratégia 3A 


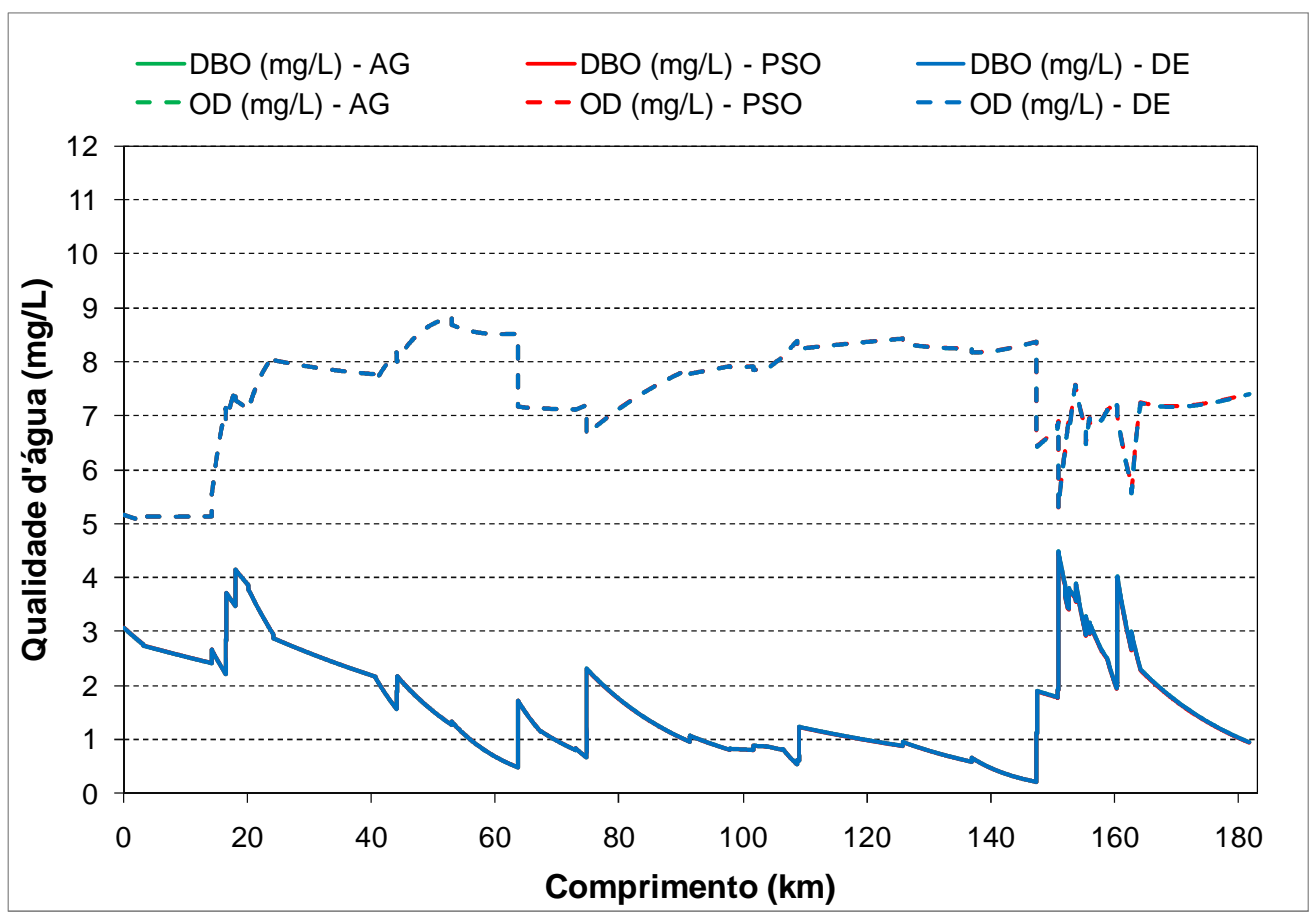

Figura 7.35 - Perfil de OD e DBO para os algoritmo AG, PSO e DE otimizando a estratégia 3B

A Figura 7.36 e a Figura 7.37 mostram o perfil do resultado da otimização com o algoritmo AG para a estratégia $2 \mathrm{~A}$ e $2 \mathrm{~B}$, respectivamente. Como nas estratégias 1 e 2 , as Figuras apresentam os perfis de OD, DBO, a vazão nos trechos e as vazões necessárias para diluir os efluentes nos pontos de lançamento.

$\mathrm{Na}$ estratégia $3 \mathrm{~A}$, as demandas são atendidas em sua totalidade e na estratégia $3 \mathrm{~B}$ permite-se o não atendimento total das demandas. A Figura 7.38 e a Figura 7.39 apresentam o perfil da qualidade e das vazões nos trechos e de diluição nos pontos de lançamento obtidos a partir do algoritmo $\mathrm{PSO}$, para as estratégias $3 \mathrm{~A}$ e $3 \mathrm{~B}$, respectivamente.

Os resultados obtidos, para a qualidade da água e das vazões ao longo do rio Atibaia, através da otimização do sistema com o algoritmo DE podem ser observados na Figura 7.40 e na Figura 7.41 para a estratégia 3A e 3B, respectivamente.

Os algoritmos AG, PSO e DE buscaram maximizar a vazão de diluição, usando a capacidade de assimilação do corpo receptor nas estratégias $3 \mathrm{~A}$ e $3 \mathrm{~B}$. Diferente do observado nas estratégias 1 e 2 , nota-se que em nenhum trecho os valores de OD e a DBO aproximaram-se do valor limite da classe de enquadramento do corpo d'água ( $5 \mathrm{mg} / \mathrm{L}$ ), onde os valores máximos observados no perfil de qualidade é de aproximadamente $4 \mathrm{mg} / \mathrm{L}$ de DBO para os três algoritmos. 


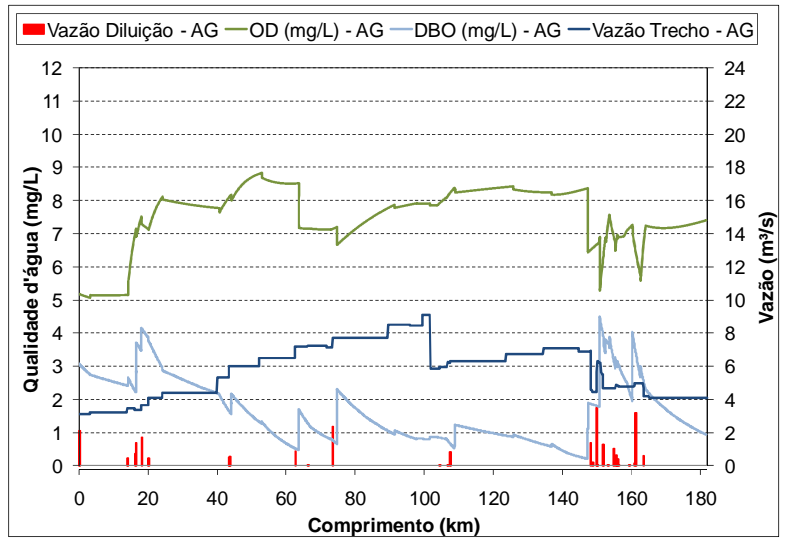

Figura 7.36 - Perfil de OD e DBO, vazão do trecho e vazão de diluição para estratégia $3 \mathrm{~A}$ obtido com o AG

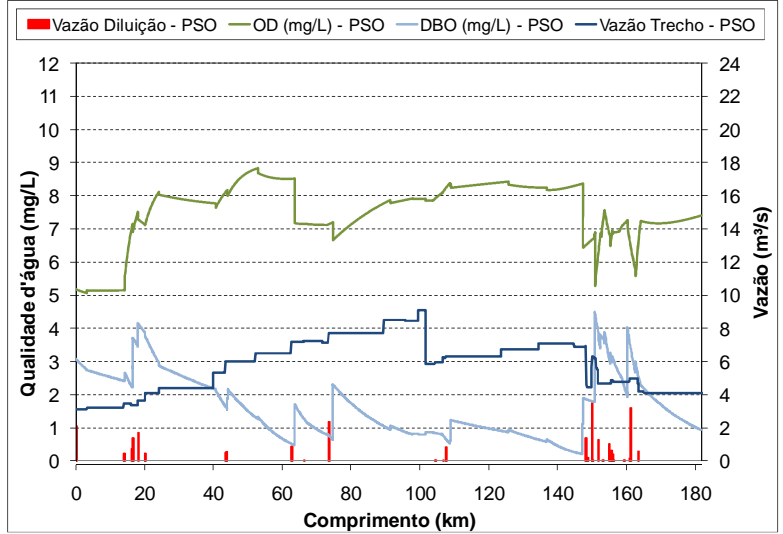

Figura 7.38 - Perfil de OD e DBO, vazão do trecho e vazão de diluição para estratégia 3 A obtido com o PSO

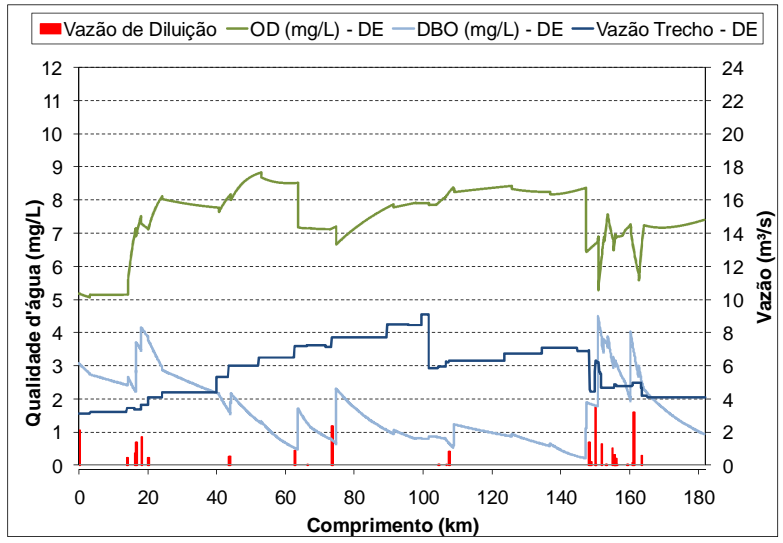

Figura 7.40 - Perfil de OD e DBO, vazão do trecho e vazão de diluição para estratégia 3 A obtido com o DE

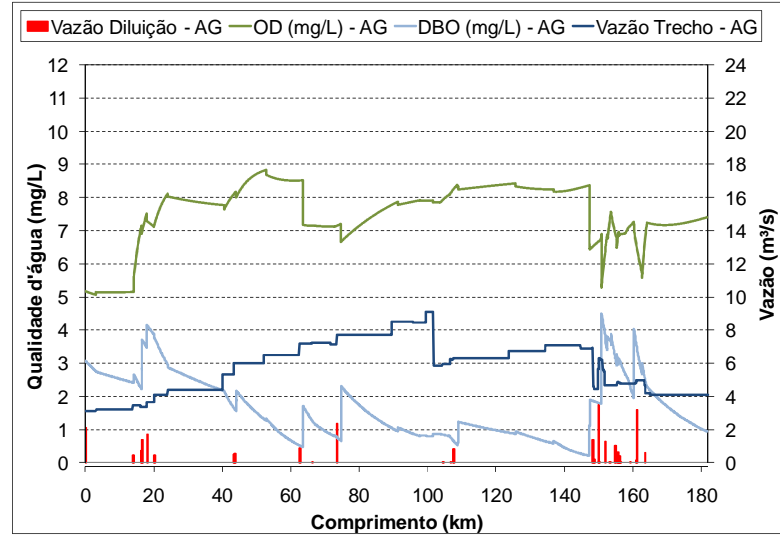

Figura 7.37 - Perfil de OD e DBO, vazão do trecho e vazão de diluição para estratégia 3 B obtido com o AG

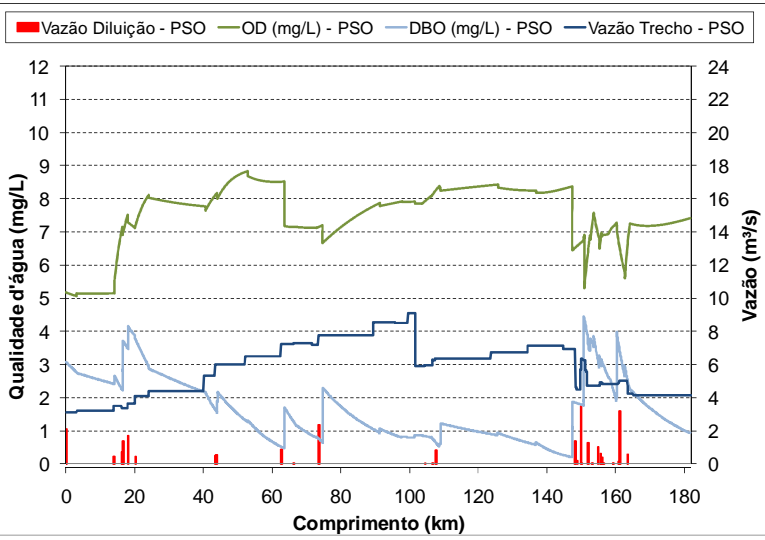

Figura 7.39 - Perfil de OD e DBO, vazão do trecho e vazão de diluição para estratégia 3 B obtido com o PSO

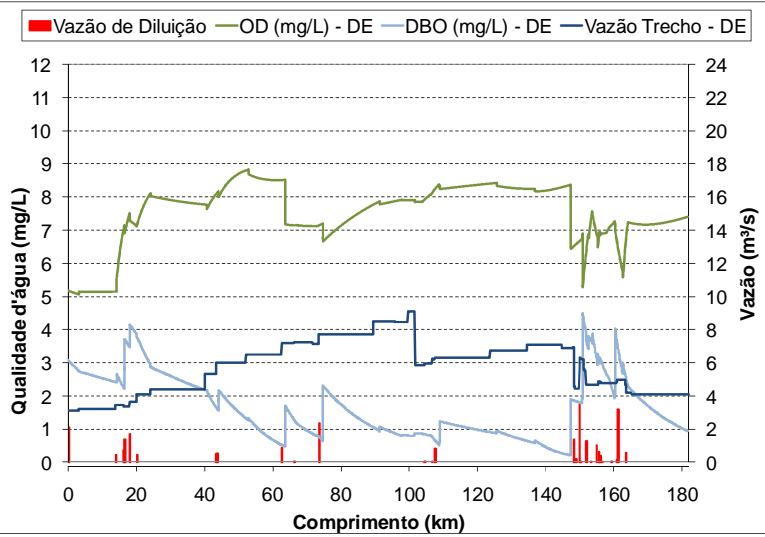

Figura 7.41 - Perfil de OD e DBO, vazão do trecho e vazão de diluição para estratégia 3 B obtido com o DE

Como pode ser analisado na Figura 7.36 à Figura 7.41, a vazão de diluição, quando avaliado o processo de outorga de efluentes considerando a isonomia entre os usuários, não utiliza a vazão total disponível no trecho, como observado nas estratégias 1 e 2 . Esta constatação permite concluir que devido às restrições impostas, de isonomia, não foi maximizado o uso do volume de água disponível no rio para a diluição, uma vez que este critério estabelece níveis iguais de tratamento para todos os usuários com mesma finalidade 
de uso. Isto acarreta, muitas vezes, no estabelecimento de níveis de tratamento maiores que os necessários para manter os limites estipulados pelo enquadramento dos corpos d'água. A Figura 7.42 e a Figura 7.43 apresentam o custo das medidas de despoluição adotada para cada trecho e o custo global para cada algoritmo nas estratégias de outorga $3 \mathrm{~A}$ e $3 \mathrm{~B}$, respectivamente.

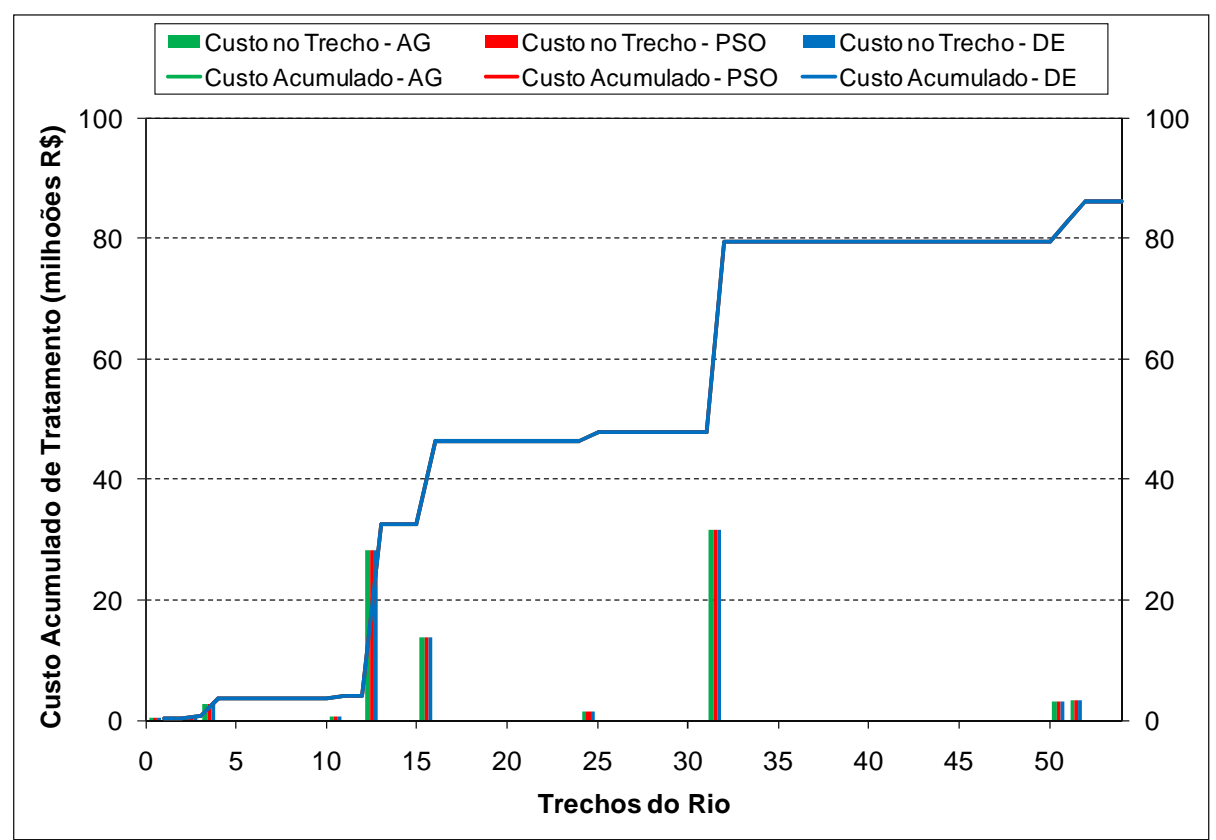

Figura 7.42 - Distribuição dos custos das medidas de despoluição ao longo dos trechos e acumulada para a estratégia de outorga $3^{a}$

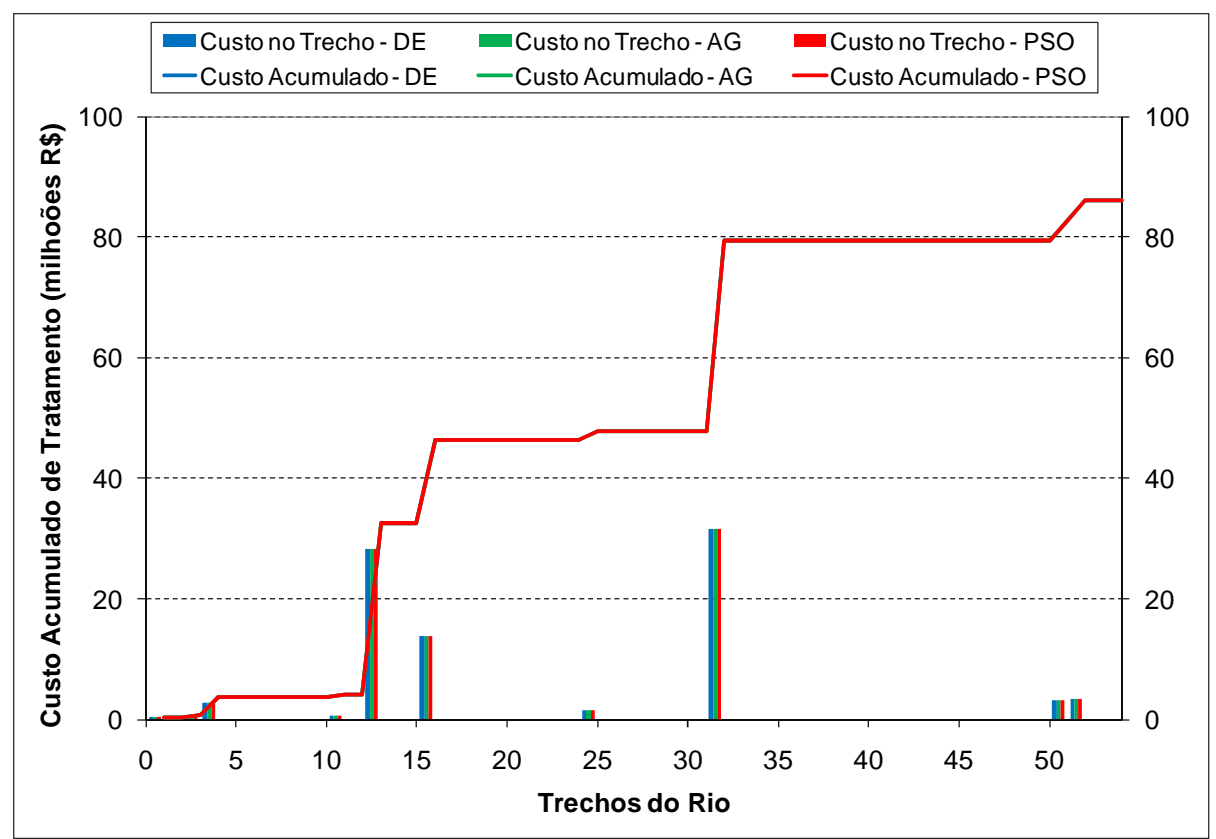

Figura 7.43 - Distribuição dos custos das medidas de despoluição ao longo dos trechos e acumulada para a estratégia de outorga 3B

Como indicado na Figura 7.42 e na Figura 7.43, os custos das medidas nos trechos de lançamento, assim como, o custo global, de aproximadamente $R \$ 86$ milhões, foram 
iguais nas duas estratégias, 3A e 3B, diferentemente do que foi obtido nas estratégias 1 e 2 . Isto é explicado pela isonomia, onde em função dos níveis de tratamento adotados para os grupos de usuários com mesma finalidade de uso, para obedecer ao critério, a ocorrência de déficits não melhorou a resposta do modelo, e assim, foi concedida toda a vazão requerida. Este resultado mostra que se as eficiências de tratamento adotadas foram elevadas e o perfil de qualidade se manteve sempre dentro dos níveis estipulados pelo enquadramento, assim sendo, o otimizador entende que não existe a necessidade de restringir o uso consuntivo.

\subsubsection{Comparação entre as estratégias de outorga}

Como discutido no Item anterior, os algoritmos AG, PSO e DE apresentaram resposta semelhantes para as estratégias adotadas, assim sendo, neste Item são apresentados detalhadamente os resultados obtidos apenas com o Algoritmo Genético, tendo em vista a comparação das estratégias de outorga.

Esta análise foi realizada com as estratégias anteriormente definidas pelo Grupo A (1A, 2A e 3A). A estratégia traçada pelo Grupo A não considerou a demanda como sendo uma variável a ser otimizada, ou seja, a vazão captada é igual a vazão requerida por cada usuário. Assim não considerando déficits de vazão para as captações pode se ter um controle maior da influência de cada estratégia na solução.

Cabe lembrar que a estratégia 1 não considera restrições como isonomia entre usuários e a legislação ambiental. Na estratégia 2, a restrição é referente ao atendimento da legislação ambiental e na estratégia 3 quanto à isonomia entre os usuários com as mesmas finalidades de uso.

A Figura 7.44 apresenta o perfil de qualidade de água (OD e $D B O$ ) para as três estratégias de outorga, $1 \mathrm{~A}, 2 \mathrm{~A}$ e $3 \mathrm{~A}$. O perfil de $\mathrm{DBO}$, na Figura, indica que quanto mais restritiva for a estratégia, restringindo o espaço de busca da solução como nos casos das estratégias $2 \mathrm{~A}$ e $3 \mathrm{~A}$, que consideraram a Lei Ambiental e a Isonomia entre os usuários, respectivamente, maiores serão as eficiências de tratamento de efluentes impostas pelo otimizador. Em virtude disto, pode-se observar na Figura 7.44 que o perfil de DBO para a estratégia 1 foi o que se manteve mais próximo dos limites máximos previstos pela classe de enquadramento, a qual não possui restrições tais como as observadas nas estratégias 2 e 3. 


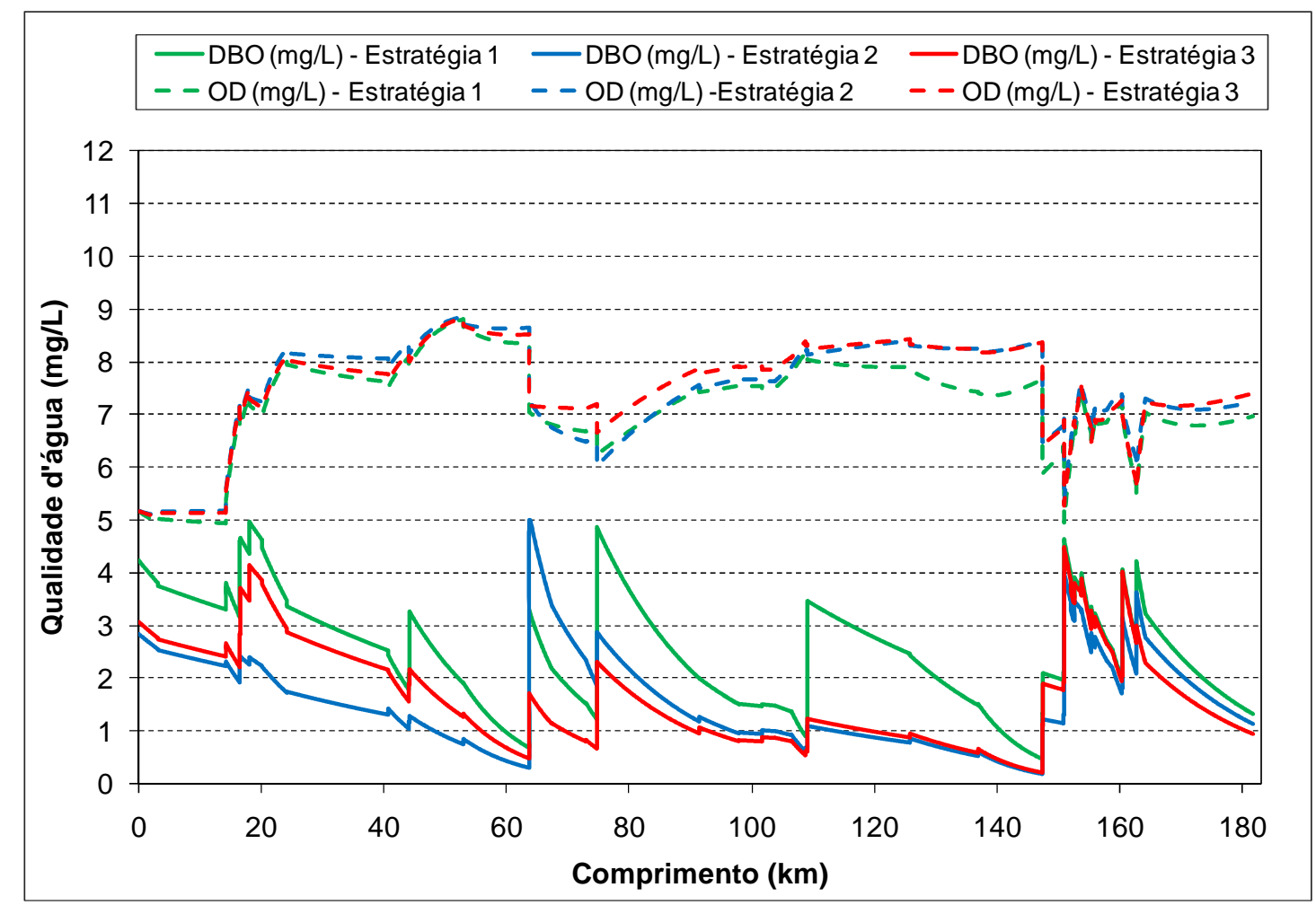

Figura 7.44 - Perfil de DBO e OD obtido para cada estratégia de outorga analisada

A Figura 7.45, Figura 7.46 e Figura 7.47 indicam o perfil de qualidade da água, assim como as vazões nos trechos do Rio Atibaia e as vazões de diluição necessárias para diluir os efluentes em seus pontos de lançamentos para as estratégias traçadas para este estudo de caso, estratégia $1 \mathrm{~A}, 2 \mathrm{~A}$ e $3 \mathrm{~A}$, respectivamente.

Destaca-se que o algoritmo obedeceu aos limites estabelecidos pela classe de enquadramento nas três estratégias propostas, no entanto, algumas considerações são importantes de serem analisadas.

A Figura 7.45 ilustra os resultados da estratégia $1 \mathrm{~A}$, onde pode ser observado que a vazão disponível nos trechos de lançamento foi utilizada para diluir os efluentes. A Figura indica que quando o perfil de qualidade atinge os limites máximos permitidos a vazão de diluição se iguala a vazão disponível no trecho, isto pode ser visualizado nos kilômetros 18 , 74 e 162. A vazão de diluição total obtida na estratégia $1 \mathrm{~A}$ foi $44,45 \mathrm{~m}^{3} / \mathrm{s}$ e a carga total lançada ao rio foi 12,77 Toneladas DBO/dia. 


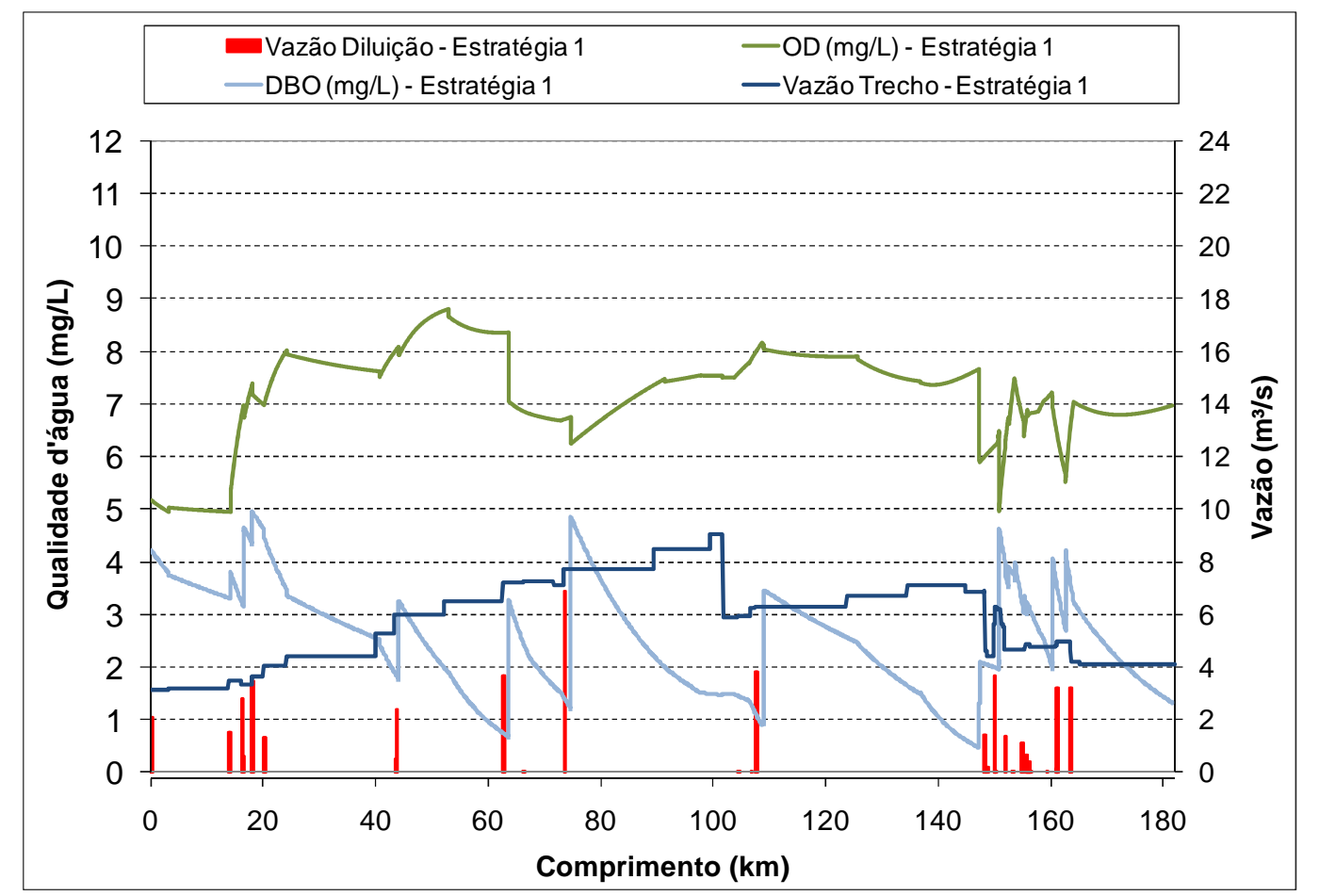

Figura 7.45 - Perfil de qualidade, vazão no trecho e vazão de diluição no trecho para a Estratégia $1 \mathrm{~A}$

Os resultados produzidos pela estratégia $2 \mathrm{~A}$ podem ser visualizados na Figura 7.46, onde, diferente do observado na estratégia $1 \mathrm{~A}$, a vazão de diluição não utilizou a totalidade da vazão disponível nos trechos com lançamento para diluir os poluentes, com excessão do kilômetro 63 , onde a vazão de diluição igualou-se a vazão disponível no trecho. Ao estabelecer a restrição para o atendimento à legislação ambiental o otimizador especificou níveis de tratamento mais elevados aos efluentes. Neste caso, as medidas de tratamento aplicadas foram maiores que o necessário para manutenção da classe. A vazão de diluição total obtida na estratégia $2 A$ foi $22,55 \mathrm{~m}^{3} / \mathrm{s}$ e a carga total lançada ao rio foi 9,14 Toneladas DBO/dia. 


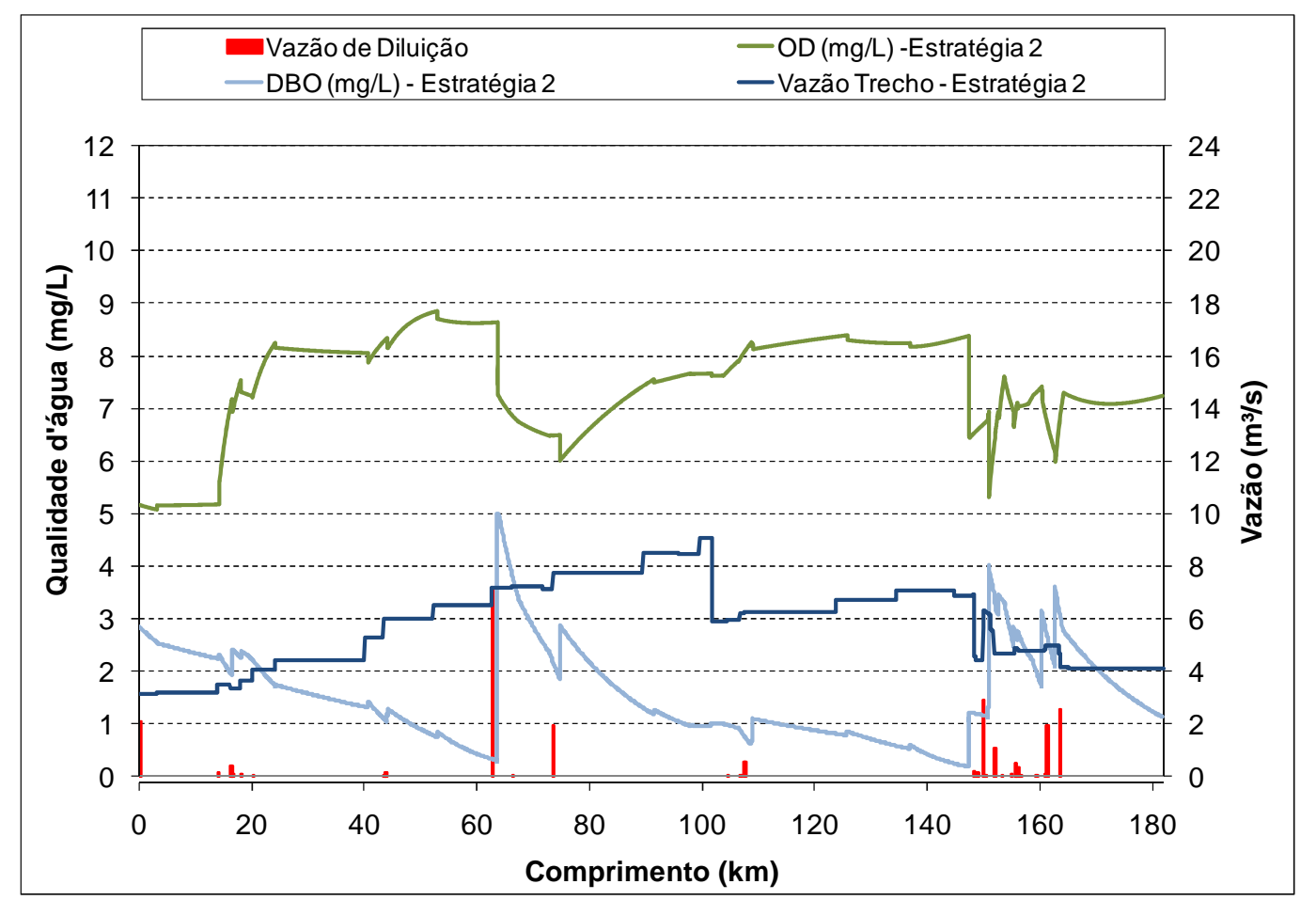

Figura 7.46 - Perfil de qualidade, vazão no trecho e vazão de diluição no trecho para a Estratégia 2A

A Figura 7.47 indica os resultados da estratégia $3 A$, onde visualiza-se comportamento semelhante ao obtido para a estratégia $2 \mathrm{~A}$ quando analisada a vazão de diluição.

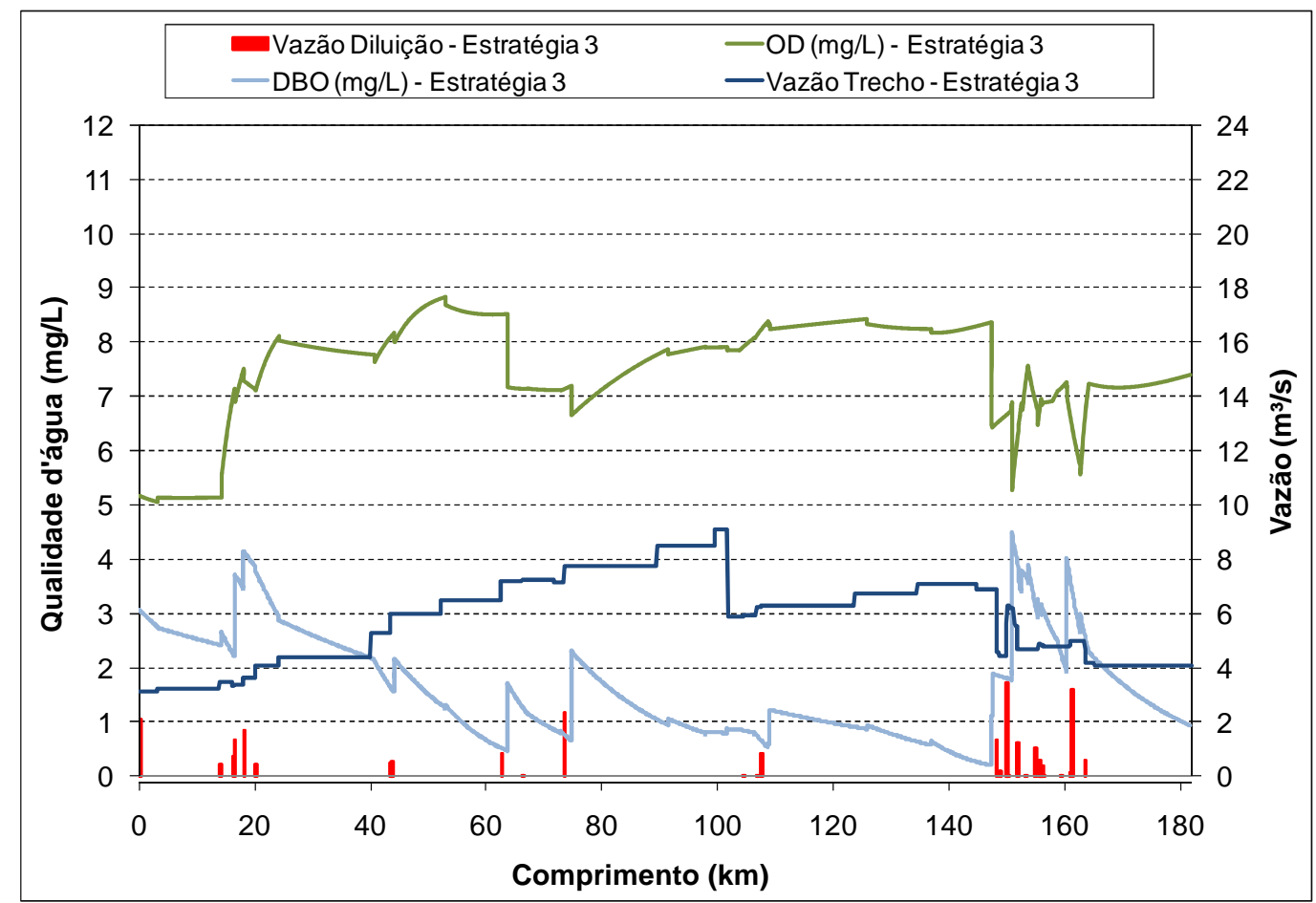

Figura 7.47 - Perfil de qualidade, vazão no trecho e vazão de diluição no trecho para a Estratégia 3A 
Nesta estratégia, a vazão de diluição não se igualou a vazão disponível no trecho em nenhum ponto de lançamento de efluente. O perfil de qualidade permaneceu distante dos limites máximos e mínimos, DBO e OD, respectivamente, estabelecidos pelo enquadramento, pois ao considerar a isonomia entre os usuários, com mesma finalidade de uso, o otimizador estabelece o mesmo grau de tratamento independentemente da qualidade do corpo hídrico no local de lançamento. Este critério impõe remoção de carga superior a necessária para manter os padrões de qualidade da água ditados pelo enquadramento. $A$ vazão de diluição total obtida na estratégia $3 A$ foi $24,06 \mathrm{~m}^{3} / \mathrm{s}$ e a carga total lançada ao rio foi 8,20 Toneladas DBO/dia.

A análise das cargas remanescentes de DBO obtidas em cada estratégia mostrou que a carga diminui proporcionalmente com o aumento das restrições. A vazão de diluição apresenta um comportamento semelhante, onde observa-se a diminuição da vazão necessária para diluir os efluentes a medida que são implantadas as estação de tratamento de efluentes. A localização do ponto de lançamento tem influência no valor da vazão de diluição, uma vez que a concentração do parâmetro de qualidade do corpo receptor é considerada no cálculo da vazão de diluição.

Os perfis de qualidade da água apresentados na Figura 7.44, Figura 7.45, Figura 7.46 e Figura 7.47 indicam que quanto mais restritivas forem as estratégias de outorga, melhor será a qualidade da água, ou seja, o perfil de qualidade se afasta dos limites máximos e mínimos, estipulados para as classe de enquadramento, para DBO e OD, respectivamente. Quanto à vazão requerida para a diluição, observa-se que para os pontos críticos, em que rio apresenta um maior estado de degradação, a estratégia de outorga $1 \mathrm{~A}$ utilizou melhor os volumes disponíveis para a diluição dos efluentes do que as estratégias $2 A$ e $3 A$.

$\mathrm{Na}$ Figura 7.48, é apresentado os custos das estações de tratamento nos trechos onde existem lançamentos e o custo global acumulado para as estratégias de outorga $1 \mathrm{~A}$, $2 \mathrm{~A}$ e $3 \mathrm{~A}$. Os custos globais estão diretamente relacionados ao nível de restrição impostos em cada estratégia.

Como pode ser analisado na Figura 7.48, a estratégia 1 apresentou o menor custo global quando comparado as estratégias 2 e 3, por representar um cenário que não considerou restrições, tais como, legislação ambiental e isonomia. Este cenário utilizou a vazão disponibilizada no trecho para diluir o efluente. $O$ custo total desta estratégia foi $R \$$ 68,8 milhões.

Por sua vez, a estratégia 2, que apresentou como restrição o atendimento à legislação ambiental, obteve custo global mais elevado quando comparado a estratégia 1. Isto se deve ao fato do otimizador ter imposto maior nível de tratamento para os efluentes, 
tendo em vista o cumprimento da legislação ambiental para lançamento de efluentes. $O$ custo total da estratégia 2 foi $R \$ 72,1$ milhões.

A estratégia 3, como era de se esperar, foi a que apresentou custo global mais elevado, devido à imposição da restrição de isonomia entre os usuários. Este tipo de restrição não permite ao otimizador variar o nível de tratamento, entre os usuários com mesma finalidade de uso, quando a qualidade do corpo receptor assim o permitir. Isto exige que todos os usuários apliquem o mesmo grau de tratamento, o que onera o custo total. 0 custo total da estratégia 3 foi $R \$ 86,2$ milhões.

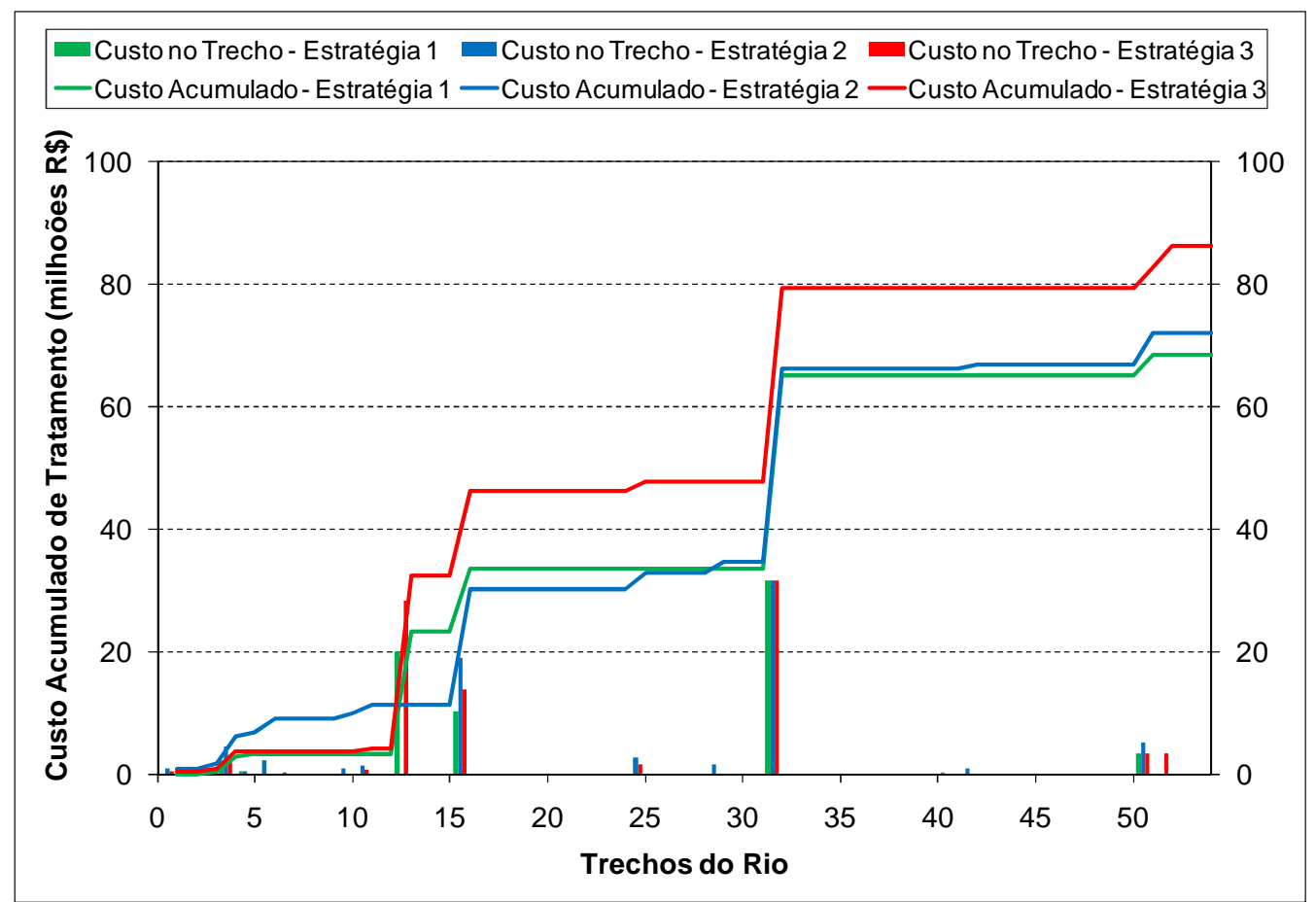

Figura 7.48 - Distribuição dos custos das medidas de despoluição ao longo dos trechos e acumulada para a estratégia as estratégias $1 \mathrm{~A}, 2 \mathrm{~A}$ e $3 \mathrm{~A}$.

A Tabela 7.10 indica a localização das estações de tratamento propostas para os trechos com lançamento em cada estratégia de outorga de efluentes (estratégia 1, 2 e 3), observam-se também a eficiência de remoção de carga, o tipo de tratamento e o custo de implantação da estação. 
Tabela 7.10- Resultados obtidos para os trechos onde há lançamento de efluentes, pelo algoritmo AG, nas Estratégia de Outorga 1A (Sem Restrições), 2A (Isonomia entre os usuários) e 3A (Legislação Ambiental) para a concessão de outorga para o Rio Atibaia

\begin{tabular}{|c|c|c|c|c|c|c|c|c|c|c|}
\hline \multicolumn{2}{|c|}{ Estratégia de Outorga } & \multicolumn{3}{|c|}{$1 \mathrm{~A}$} & \multicolumn{3}{|c|}{$2 A$} & \multicolumn{3}{|c|}{$3 A$} \\
\hline 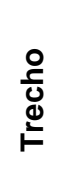 & 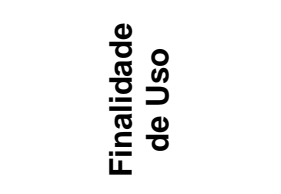 & 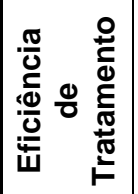 & 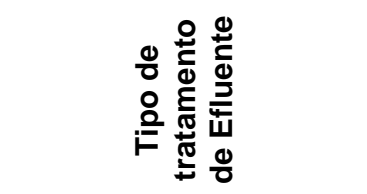 & 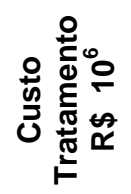 & 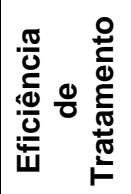 & 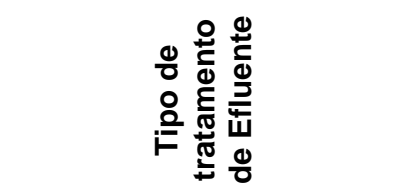 & 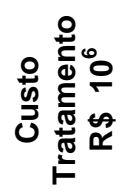 & 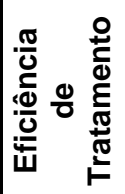 & 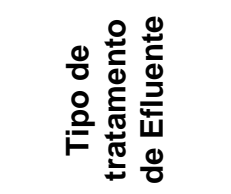 & 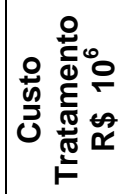 \\
\hline 1 & Doméstico & 75 & Reator UASB & 0.394 & 90 & $\begin{array}{c}\text { Lodo Ativado por Aeração } \\
\text { Prolongada }\end{array}$ & 0.879 & 75 & Reator UASB & 0.395 \\
\hline 3 & Doméstico & 45 & Tratamento Avançado & 0.377 & 90 & $\begin{array}{c}\text { Lodo Ativado por Aeração } \\
\text { Prolongada } \\
\end{array}$ & 0.879 & 75 & Reator UASB & 0.395 \\
\hline 4 & Doméstico & 45 & Tratamento Avançado & 2.330 & 83 & Reator UASB + Lodo Ativado & 4.456 & 75 & Reator UASB & 2.804 \\
\hline 5 & Industrial Alimentícia & 90 & $\begin{array}{c}\text { Lodo Ativado por Aeração } \\
\text { Prolongada }\end{array}$ & 0.570 & 90 & $\begin{array}{c}\text { Lodo Ativado por Aeração } \\
\text { Prolongada } \\
\end{array}$ & 0.570 & 0 & Sem Tratamento & - \\
\hline 6 & Industrial Química & 0 & Sem Tratamento & - & 75 & Reator UASB & 2.229 & 0 & Sem Tratamento & - \\
\hline 7 & Industrial Textil & 0 & Sem Tratamento & - & 90 & $\begin{array}{c}\text { Lodo Ativado por Aeração } \\
\text { Prolongada }\end{array}$ & 0.069 & 0 & Sem Tratamento & - \\
\hline 10 & Industrial Alimentícia & 0 & Sem Tratamento & - & 90 & $\begin{array}{c}\text { Lodo Ativado por Aeração } \\
\text { Prolongada }\end{array}$ & 0.879 & 0 & Sem Tratamento & - \\
\hline 11 & Doméstico & 0 & Sem Tratamento & - & 90 & $\begin{array}{c}\text { Lodo Ativado por Aeração } \\
\text { Prolongada }\end{array}$ & 1.276 & 75 & Reator UASB & 0.589 \\
\hline 13 & Doméstico & 45 & Tratamento Avançado & 19.993 & 0 & Sem Tratamento & - & 75 & Reator UASB & 28.341 \\
\hline 14 & Industrial Química & 0 & Sem Tratamento & - & 0 & Sem Tratamento & - & 0 & Sem Tratamento & - \\
\hline 16 & Doméstico & 45 & Tratamento Avançado & 10.242 & 83 & Reator UASB + Lodo Ativado & 19.031 & 75 & Reator UASB & 13.798 \\
\hline 21 & Industrial Alimentícia & 0 & Sem Tratamento & - & 0 & Sem Tratamento & - & 0 & Sem Tratamento & - \\
\hline 22 & Industrial Textil & 0 & Sem Tratamento & - & 0 & Sem Tratamento & - & 0 & Sem Tratamento & - \\
\hline 24 & Industrial Alimentícia & 0 & Sem Tratamento & - & 0 & Sem Tratamento & - & 0 & Sem Tratamento & - \\
\hline 25 & Doméstico & 0 & Sem Tratamento & - & 83 & Reator UASB + Lodo Ativado & 2.592 & 75 & Reator UASB & 1.547 \\
\hline 26 & Industrial Alimentícia & 0 & Sem Tratamento & - & 0 & Sem Tratamento & - & 0 & Sem Tratamento & - \\
\hline 27 & Industrial Química & 0 & Sem Tratamento & - & 0 & Sem Tratamento & - & 0 & Sem Tratamento & - \\
\hline 28 & Industrial Alimentícia & 0 & Sem Tratamento & - & 0 & Sem Tratamento & - & 0 & Sem Tratamento & - \\
\hline 29 & Industrial Química & 0 & Sem Tratamento & - & 83 & Reator UASB + Lodo Ativado & 1.674 & 0 & Sem Tratamento & - \\
\hline 31 & Industrial Alimentícia & 0 & Sem Tratamento & - & 0 & Sem Tratamento & - & 0 & Sem Tratamento & - \\
\hline 32 & Doméstico & 75 & Reator UASB & 31.613 & 75 & Reator UASB & 31.613 & 75 & Reator UASB & 31.613 \\
\hline
\end{tabular}




\begin{tabular}{|c|c|c|c|c|c|c|c|c|c|c|}
\hline \multicolumn{2}{|c|}{ Estratégia de Outorga } & \multicolumn{3}{|c|}{$1 \mathrm{~A}$} & \multicolumn{3}{|c|}{$2 A$} & \multicolumn{3}{|c|}{$3 A$} \\
\hline 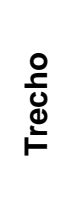 & 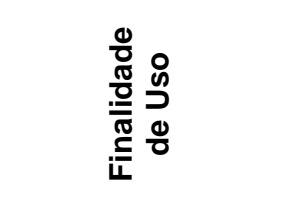 & 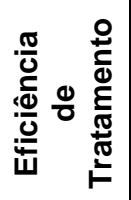 & 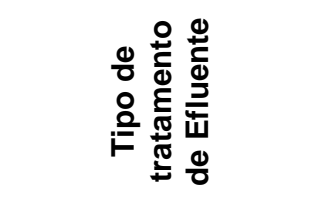 & 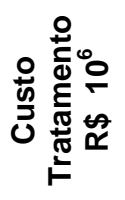 & 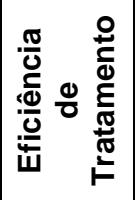 & 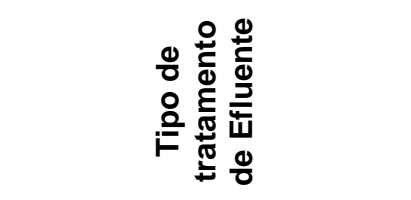 & 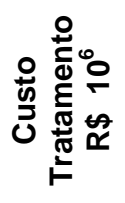 & 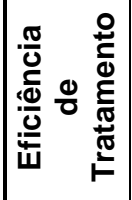 & 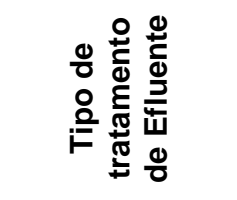 & 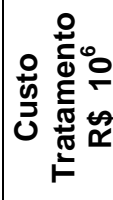 \\
\hline 33 & Industrial Química & 0 & Sem Tratamento & - & 0 & Sem Tratamento & - & 0 & Sem Tratamento & - \\
\hline 39 & Industrial Alimentícia & 0 & Sem Tratamento & - & 0 & Sem Tratamento & - & 0 & Sem Tratamento & - \\
\hline 41 & Industrial Química & 45 & Tratamento Avançado & 0.013 & 0 & Sem Tratamento & - & 0 & Sem Tratamento & - \\
\hline 42 & Industrial Química & 0 & Sem Tratamento & - & 83 & Reator UASB + Lodo Ativado & 0.828 & 0 & Sem Tratamento & - \\
\hline 43 & Industrial Alimentícia & 0 & Sem Tratamento & - & 0 & Sem Tratamento & - & 0 & Sem Tratamento & - \\
\hline 44 & Industrial Textil & 0 & Sem Tratamento & - & 0 & Sem Tratamento & - & 0 & Sem Tratamento & - \\
\hline 45 & Industrial Textil & 0 & Sem Tratamento & - & 0 & Sem Tratamento & - & 0 & Sem Tratamento & - \\
\hline 46 & Industrial Alimentícia & 0 & Sem Tratamento & - & 0 & Sem Tratamento & - & 0 & Sem Tratamento & - \\
\hline 48 & Industrial Alimentícia & 0 & Sem Tratamento & - & 0 & Sem Tratamento & - & 0 & Sem Tratamento & - \\
\hline 50 & Industrial Textil & 0 & Sem Tratamento & - & 0 & Sem Tratamento & - & 0 & Sem Tratamento & - \\
\hline 51 & Doméstico & 75 & Reator UASB & 3.259 & 83 & Reator UASB + Lodo Ativado & 5.110 & 75 & Reator UASB & 3.259 \\
\hline 52 & Doméstico & 0 & Sem Tratamento & - & 0 & Sem Tratamento & - & 75 & Reator UASB & 3.438 \\
\hline
\end{tabular}


Uma breve comparação entre as diferentes estratégias propostas pode ser obtida observando-se as eficiências de tratamento dos efluentes lançados nos trechos do rio Atibaia, onde na estratégia 1 as eficiências estipuladas pelo otimizador variaram entre 45, 75 e $90 \%$. Já para a estratégia 2, mais restritiva, pois considera a legislação ambiental para os padrões de lançamento, as eficiências estipuladas variam entre 75, 83 e 90\%, observa-se também um maior número de estações. Na estratégia 3, fica evidente a isonomia entre os usuários, uma vez que o nível de tratamento foi o mesmo para o grupo de usuários com mesma finalidade de uso. A eficiência de tratamento na estratégia 3 foi de $75 \%$ remoção de carga poluente para os usuários com finalidade doméstica.

A estratégia 1 apresenta os resultados com maior grau de liberdade quando se analisam as restrições impostas ao otimizator. Assim sendo, para obter o melhor resultado os usuários são avaliados de forma independente, onde a eficiência de tratamento não está vinculada a outro uso, da mesma forma em que não é verificado o valor da concentração final do lançamento. Nesta estratégia, o perfil de qualidade do corpo receptor é verificado, tendo em vista não ultrapassar os limites estabelecidos pela classe de enquadramento, assim como, os limites de mínimo e máximo de tratamento impostos como dado de entrada para cada usuário de forma independente ou por finalidade de uso. A estratégia 1 apresenta o menor custo global para a implementação das medidas de despoluição.

Os resultados obtidos pela estratégia 2 estão muito próximos aos da estratégia 1, a principal diferença é que a estratégia 2 avalia a legislação ambiental para lançamento de efluentes, o que exige a imposição de tratamento para os efluentes com carga elevada, independentemente da localização destes da bacia.

A estratégia 3 analisa a isonomia entre os usuários, o que impede de indicar tratamentos com diferentes eficiências para usuários de mesma finalidade. Ressalta-se que os limites inferiores de tratamentos de cada finalidade de uso podem ser alterados nos dados de entrada do SSD, o que permite a imposição de tratamentos mínimos para cada finalidade de uso, e, assim, diminuir a desigualdade na adoção das medidas entre os diferentes usos. Este tipo de estratégia restringe as soluções possíveis, o que pode acarretar em maior custo global para as medidas de despoluição adotadas. A distribuição espacial dos usuários na bacia torna-se um fator importante, pois caso um usuário que apresente seu efluente com elevada carga poluente estiver localizado em um trecho do rio com baixa capacidade de diluição, este usuário deverá aplicar um tratamento com elevada remoção de carga, o qual deverá ser aplicado igualmente para os usuários com mesma finalidade de uso.

Uma análise geral sobre as três estratégias propostas permite dizer que a estratégia 1 é mais favorável economicamente para a bacia, pois além de respeitar os limites estabelecidos pelo enquadramento, apresentou o menor custo global. Porém, esta 
estratégia não considera as violações da legislação ambiental e o critério de isonomia entre os usuários. No entanto, a legislação ambiental e a isonomia entre os usuários devem ser consideradas, tendo em vista o cumprimento dos padrões estabelecidos para o lançamento de efluentes e a solução de conflitos entre os usuários, respectivamente.

Outra questão que deve ser abordada é a necessidade de integração dos instrumentos de gestão de recursos hídricos para a mediação de possíveis conflitos. Por exemplo, quando se analisa a isonomia, a cobrança pelo uso pode inserir em seus valores uma compensação aos usuários que são obrigados a aplicar maior nível de tratamento devido à baixa capacidade de diluição do corpo receptor no seu local de lançamento. Assim, ao invés de impor os mesmos níveis de tratamento a todos os usuários com mesma finalidade de uso, o instrumento de cobrança teria a função de amenizar as diferenças entre os usuários, onde o que tratar menos, devido à sua localização na bacia, deverá pagar mais pelo uso do recurso.

Neste contexto de seleção de estratégias, destaca-se o importante papel do Comitê de Bacia em definir as prioridades, tendo em vista que os critérios aqui discutidos, legislação ambiental e isonomia, acarretam em investimentos mais elevados para a implementação das medidas de tratamento. Desta forma, o Comitê deve priorizar o desenvolvimento sustentável da bacia.

As estratégias de outorga de efluentes propostas neste Item indicam uma pequena amostra da potencialidade do SSD desenvolvido nesta tese, uma vez que inúmeras outras combinações são possíveis de serem aplicadas para a avaliação da outorga. Como visto, o SSD proposto traz relevante contribuição para o processo de análise da outorga de efluentes, através das estratégias estabelecidas.

O SSD permite analisar os usos de forma independente, atribuindo os limites inferiores e superiores para as remoções de carga de cada usuário ou finalidade de uso, assim como, permite atribuir novas funções de custo de implantação de estações de tratamento por finalidade de uso.

\subsection{Considerações do sobre o SSD proposto para Outorga de Efluentes}

Os Sistemas de Suporte a Decisão (SSD) integram em uma plataforma única a base de dados necessária para as análises, modelos de simulação e algoritmos de otimização. Esta integração permite estudar sistemas complexos, como é o caso da outorga de efluentes em bacias críticas, para o qual não existe apenas uma solução viável e sim diversas respostas, as quais dependem do cenário de qualidade da água, de escassez hídrica, das estratégias de outorga selecionadas e da disponibilidade financeira. 
O SSD desenvolvido considera integradamente uma série de parâmetros relacionados ao processo de decisório. A Figura 7.49 ilustra os parâmetros considerados no SSD para outorga de efluentes.

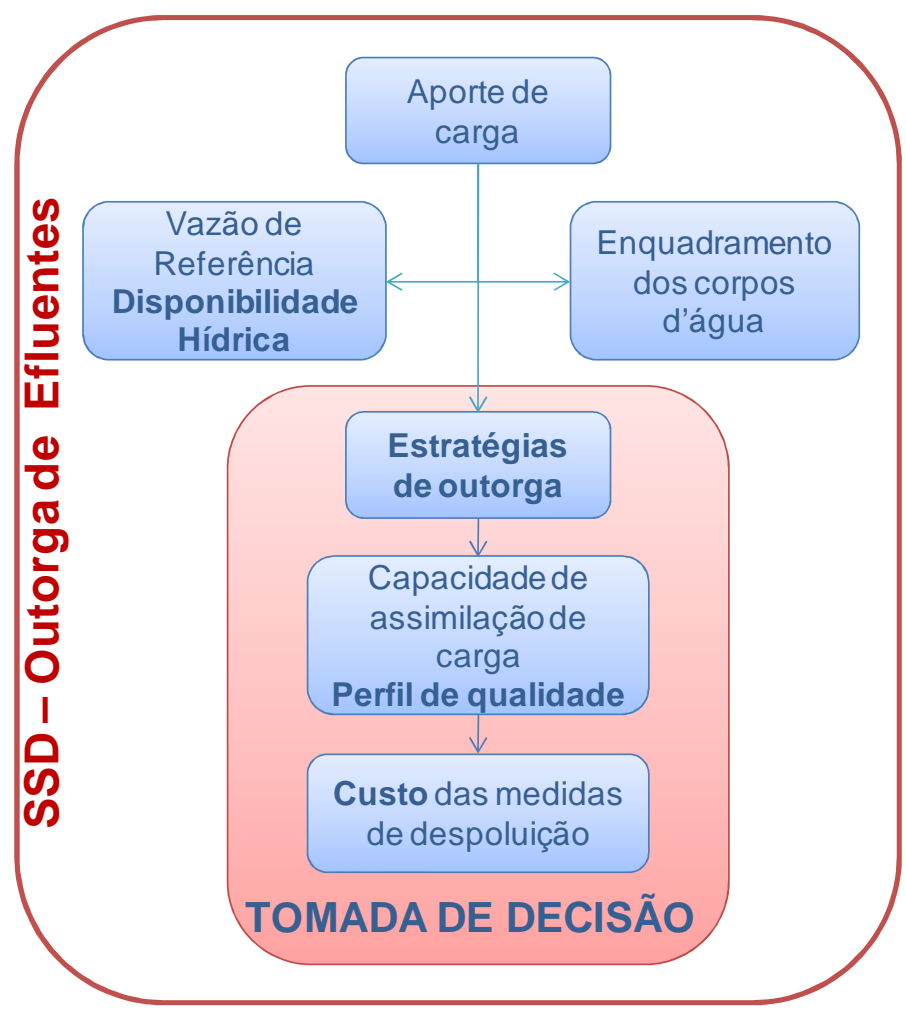

Figura 7.49 - Parâmetros integrados na análise do SSD para outorga de efluentes

O SSD proposto nesta tese permite a análise otimizada e integrada entre os aspectos de quantidade e qualidade da água, permitindo se que avaliem as estratégias de outorga estabelecidas tendo em vista a redução dos custos de implementação das medidas de despoluição.

Desta forma, pode-se destacar que o SSD proposto contribui para o processo de gestão de recursos hídricos, uma vez que possibilita análises complexas, considerando diferentes estratégias para a concessão da outorga sem desconsiderar os parâmetros de quantidade e qualidade da água e a viabilidade financeira das alternativas propostas. As estratégias inicialmente inseridas no SSD foram a obediência da legislação ambiental e do critério de isonomia entre usuários com mesma finalidade de uso. Destaca-se o importante papel do Comitê de Bacia na seleção da melhor estratégia para a bacia, onde o processo deve ser participativo tendo em vista o cumprimento das metas estabelecidas.

O processo de otimização utilizou os algoritmos evolucionários AG, PSO e o DE, os quais mostraram-se flexíveis para a introdução de restrições e penalidades para processo decisório. Isto permite a introdução de diferentes estratégias de outorga ou simplesmente a alteração de critérios específicos para cada bacia hidrográfica. O caráter flexível das 
ferramentas desenvolvidas para o processo decisório é fundamental para o sistema de gestão, pois as metodologias utilizadas estão em contínua evolução e esta característica permite o aperfeiçoamento e a inclusão de novas estratégias de análise no SSD.

As restrições e penalidades impostas no estudo de caso apresentado, buscaram satisfazer os critérios adotados nas diferentes estratégias. A otimização realizada, no estudo de caso apresentado, buscou a maximização dos usos na bacia e a redução dos custos de implementação das medidas de despoluição, visando à manutenção dos padrões de qualidade estabelecidos pelo enquadramento do corpo d'água, assim como respeitar as restrições impostas pelas estratégias analisadas.

As estratégias para as análises de outorga de efluentes avaliadas buscaram mostrar os impactos destas sobre a qualidade dos corpos d'água, assim como os impactos econômicos para os usuários da bacia. Observou-se que, quanto mais restritivas forem as estratégias adotadas para outorga de efluentes maiores serão os impactos econômicos.

Os resultados obtidos para a estratégia de outorga 1, a qual não avalia a obediência da legislação ambiental e a isonomia entre os usuários, mostraram que quando permite-se um maior o grau de liberdade no processo de otimização, obtém-se o aporte de carga distribuído ao logo do corpo d'água, e, desta forma, maximiza-se o uso dos volumes de água disponíveis para a diluição dos efluentes, o que leva à redução do custo global das medidas de despoluição.

A estratégia 2 impõe que nenhum usuário do sistema desrespeite os limites máximos permitidos pela legislação para o lançamento de efluentes, o que onera o custo global, pois exige-se maior remoção de carga poluente e restringe-se o uso da disponibilidade hídrica para a diluição de efluentes relacionada à capacidade de assimilação de carga do corpo receptor. A consideração da capacidade de autodepuração do corpo receptor, para as análises do processo de outorga de efluente, possui respaldo legal. Segundo a Resolução CONAMA 357/05, é permitido o aporte de carga orgânica mais elevada desde que a capacidade de assimilação de carga do corpo hídrico respeite as condições mínimas de OD. Esta visão para o sistema de outorga pode ser útil quando se deseja atender as metas progressivas estabelecidas pelo enquadramento, o que possibilita o relaxamento dos critérios até que todos os usuários do sistema se adéquem gradativamente às condições finais propostas.

A isonomia entre os usuários da água, estabelecida na estratégia 3 simulada nesta tese, mostrou-se a mais restritiva das estratégias adotadas, elevando o custo global das medidas de despoluição e aplicando níveis de tratamento elevados inclusive para usuários localizados em trechos do rio que apresentem disponibilidade de água suficiente para a diluição de seus efluentes. 
As estratégias apresentadas objetivaram a indicação da potencialidade do SSD para avaliar diferentes restrições e penalidades impostas ao processo decisório, e não impor este tipo de medidas para aplicação em todas as bacias hidrográficas.

O SSD proposto apresenta a vantagem de permitir alterações na função objetivo, assim como, a facilidade de introduzir novas penalidades e restrições, o que pode ser obtido devido às características e flexibilidade dos algoritmos evolucionários adotados para inserção no SSD.

Outras vantagens do SSD referem-se à facilidade de introduzir novas estratégias de outorga, onde podem ser impostos diferentes limites, mínimos e máximos, para as eficiências de tratamento para cada usuário da bacia ou por finalidade de uso, o que permite a avaliação dos lançamentos de forma independente. Outra particularidade do SSD relaciona-se com a possibilidade de atribuir funções de custo por finalidade de uso, o que permite a entrada de dados específicos para as diferentes técnicas de tratamento de efluentes.

A contribuição do SSD desenvolvido, para a outorga de efluentes, está na sistematização dos dados, com a integração otimizada da quantidade e qualidade da água, inserção da análise financeira das alternativas e formulação das estratégias para a análise da concessão da outorga de efluentes, em uma plataforma computacional eficiente, de fácil entendimento e capaz de produzir resultados direcionados para o processo de gestão.

A outorga de recursos hídricos é um instrumento que auxilia no planejamento da bacia hidrográfica com o disciplinamento dos usos, onde são impostas medidas de controle, através de restrições de uso ou pela imposição de eficiências de tratamento de efluentes.

Destaca-se que a concessão de outorga deve ser pautada sobre estratégias de ações definidas em comum acordo, entre usuários e órgãos gestores. O SSD proposto permite a flexibilidade que o processo de outorga exige, onde os critérios estabelecidos podem ser redefinidos em função das especificidades das bacias hidrográficas a serem analisadas.

Como visto, a análise da outorga de efluentes envolve inúmeros aspectos, os quais devem ser avaliados integradamente no processo, o que torna o problema complexo e justifica o desenvolvimento de sistemas de suporte a decisão para auxiliar as análises, como o desenvolvido desta tese. O SSD proposto, através de suas considerações e estratégias, contribuirá de forma eficiente para a efetivação do instrumento de outorga de efluentes e, consequentemente, para o sistema de gestão de recursos hídricos no país. 


\section{CONCLUSÕES}

A outorga de efluentes mostra-se um instrumento de suma importância para a efetivação da gestão de recursos hídricos, pois este instrumento permite o disciplinamento dos usos pelos órgãos gestores, tendo em vista o atendimento das demandas, o desenvolvimento econômico da bacia, a manutenção do recurso e a garantia da sustentabilidade ambiental.

A outorga como instrumento de comando e controle concede ao órgão gestor a responsabilidade de avaliar o impacto dos diversos usos na bacia hidrográfica. Destaca-se a importância da utilização de metodologias consolidadas respeitando diretrizes e regras préestabelecidas, o que permitirá o estabelecimento de estratégias de uso, através da imposição de restrições e metas a serem atingidas.

A outorga de direito de uso da água é um instrumento de simples entendimento e fácil aplicação até o instante que os primeiros conflitos surgem, sejam estes devido à escassez quantitativa ou qualitativa. Os conflitos geram polêmicas e discussões entre os usuários da bacia, onde o órgão gestor tem papel fundamental na intermediação destes conflitos.

Tento em vista a minimização dos conflitos e as dificuldades metodológicas para avaliar o processo de outorga, esta tese teve como objetivo desenvolver um Sistema de Suporte a Decisão (SSD) que auxilie a aplicação do instrumento de outorga de direito de uso, com ênfase para a outorga de lançamento de efluentes. O SSD proposto utiliza a otimização no processo de alocação de demanda e de carga efluente, visando a maximização dos usos e a minimização dos custos das medidas de tratamento de efluentes respeitando dos limites impostos pela classe de enquadramento dos corpos d'água.

O resultado otimizado, neste estudo, foi obtido através da utilização dos algoritmos evolucionários, Algoritmos Genéticos, Particle Swarm Optimization e Differential Evolution, tendo em vista à otimização do processo de alocação de demanda e de carga efluente, assim como a minimização dos custos de tratamento de efluentes e a maximização do uso da vazão disponível para diluição. Estes algoritmos também foram utilizados para obtenção da calibração automática da qualidade da água, tendo em vista facilitar a aplicação do SSD pelos órgãos gestores, o que introduz agilidade ao processo de implementação e análise do modelo de qualidade da água na bacia a ser estudada.

Entre suas estratégias de análise inseridas no SSD estão o atendimento da legislação ambiental para o lançamento de efluentes, a isonomia entre os usuários, 0 atendimento aos padrões de qualidade estabelecidos pelo enquadramento dos corpos hídricos e as restrições impostas pelo órgão gestor aos usuários ou as finalidades de uso. 
No intuito de produzir estratégias para avaliar o processo de outorga esta tese inseriu em suas análises três estratégias para a outorga de lançamento de efluentes. Na estratégia 1, foram consideradas apenas as restrições impostas pelo gestor para os limites de tratamento de efluentes mínimo e máximo impostas por usuário ou finalidade de uso. A estratégia 2 avaliou a outorga de efluentes considerando as restrições impostas pela legislação ambiental para o lançamento de efluentes, concentração máxima ou eficiência de tratamento. $\mathrm{Na}$ estratégia de outorga 3 , foi inserida como restrição a isonomia entre os usuários da bacia hidrográfica com mesma finalidade de uso, os quais devem obedecer as mesmas eficiências de tratamento de efluentes. $O$ atendimento dos limites estabelecidos pelo enquadramento dos corpos d'água para cada trecho de rio foi considerado como uma restrição para as três estratégias propostas.

As estratégias propostas neste estudo tiveram como principal objetivo avaliar o comportamento do SSD na obtenção das análises, assim como analisar a flexibilidade dos algoritmos na introdução de restrições e penalidade. Para a escolha das estratégias de outorga, destaca-se o importante papel do Comitê de Bacia e do órgão gestor para definir as prioridades, tendo em vista que os critérios aqui discutidos, legislação ambiental e isonomia, acarretam em investimentos mais elevados para a implementação das medidas de tratamento.

Para avaliar o desempenho do SSD foi realizado um estudo de caso na Bacia Hidrográfica do Rio Atibaia, no Estado de São Paulo. O Rio Atibaia foi escolhido por apresentar problemas de disponibilidade hídrica e conflitos pelo uso da água, o que permite avaliar os resultados do SSD para as diferentes estratégias em um caso real.

Os resultados obtidos pelos três algoritmos para as estratégias analisadas foram satisfatórios. Os algoritmos responderam bem as restrições e penalidades impostas à solução do problema. A estratégia 1, por apresentar característica menos restritiva que as estratégias 2 e 3, apresentou o menor custo global para a implementação das medidas de despoluição, uma vez que utilizou a vazão disponível para diluir os efluentes. Os resultados obtidos pela estratégia 2 estão próximos aos da estratégia 1. No entanto, devido à restrição que obriga o cumprimento da legislação ambiental para lançamento de efluentes, esta estratégia impôs maiores níveis de tratamento para os efluentes com carga elevada, o que resultou em um maior custo global das medidas de despoluição quando comparado com a estratégia 1.

A estratégia 3 ao priorizar a isonomia entre os usuários garante as mesmas obrigações de tratamento para usuários de mesma finalidade de uso, independente das condições de assimilação de carga poluente do corpo receptor em seu ponto de lançamento. Esta estratégia apresentou os custos mais elevados devido às características 
mais restritivas do critério adotado. Esta estratégia sofre grande influência da localização dos usuários na bacia hidrográfica.

O perfil de qualidade da água permaneceu dentro dos limites impostos pela classe de enquadramento para as três estratégias, observou-se que as estratégias 2 e 3 , devido às restrição impostas, apresentaram melhor qualidade para os parâmetros analisados, OD e DBO, ao longo do rio. Na estratégia 1, foi observado um melhor aproveitamento das vazões disponíveis para a diluição dos efluentes, este melhor desempenho é explicado pela restrição imposta à função objetivo de avaliar apenas os limites impostos pela classe de enquadramento e aos limites de tratamento informados pelo tomador de decisão. As estratégias 2 e 3, além do enquadramento devem obedecer as restrições da legislação ambiental para o lançamento e a isonomia entre usuários, respectivamente.

O Sistema de Suporte à Decisão proposto representa um avanço no processo de gestão de recursos hídricos, uma vez que envolve importantes critérios e estratégias na análise da outorga de direito de uso da água, sem dissociar os aspectos de quantidade e qualidade da água. Este avanço se deve a análise integrada dos critérios envolvidos nos processo de outorga em uma única ferramenta, que utiliza técnicas de otimização para a obtenção dos resultados, contribuindo de forma eficiente para a efetivação da gestão de recursos hídricos no Brasil.

O caráter flexível dos algoritmos escolhidos para este estudo, assim como da plataforma desenvolvida para o SSD são características que mostram as potencialidades do sistema proposto. Uma vez que o instrumento de outorga está em constante processo de evolução, seja pela indefinição das metodologias e regras a serem analisadas ou pelos novos desafios que serão impostos ao instrumento, uma vez que o uso dos recursos hídricos tende a aumentar e novos conflitos de uso certamente surgirão.

\subsection{Recomendações}

Esta tese foi desenvolvida com o objetivo de suprir a carência metodológica e estratégica para a solução dos problemas complexos envolvidos nas análises do instrumento de outorga para lançamento de efluentes. Ao longo do desenvolvimento deste estudo algumas dificuldades foram encontradas, as quais são importantes destacar tendo em vista o aprimoramento e a motivação para o desenvolvimento de trabalhos futuros.

Destaca-se a necessidade de ampliar as redes de monitoramento integrado entre quantidade e qualidade da água. Os dados de monitoramento são fundamentais para a gestão de recursos hídricos, os quais fornecem as informações sobre o comportamento atual e tendencial dos corpos hídricos, sem o qual não é possível aplicar as medidas de 
gestão e a utilização das ferramentas computacionais. A obtenção de dados de quantidade e qualidade permitem aperfeiçoar a calibração do modelo de qualidade, assim como, avaliar o comportamento do corpo hídrico em diferentes períodos, seco e úmido. O que permite introduzir outros critérios como a sazonalidade na avaliação das estratégias de outorga.

A utilização de sistemas que auxiliem o processo de gestão e planejamento dos recursos hídricos necessita a entrada de informações precisas e seguras sobre as atividades desenvolvidas no âmbito da bacia hidrográfica. Assim sendo, é de suma importância a obtenção dos cadastros de usuários mais elaborados, que apresentem informações relevantes para o processo, os quais permitam a formulação de cenários de carga e a definição de estratégias de outorga.

Outro aspecto notório é em relação ao desenvolvimento das funções de custo para implantação das estações de tratamento de esgoto, principalmente, para o tratamento de efluentes industriais, os quais diferem do tratamento de esgoto em função dos volumes tratados e pela diversidade de poluentes relacionados ao processo produtivo das indústrias. Isto permitirá a atribuição das funções de custo específicas por finalidade de uso.

O SSD proposto nesta tese foi desenvolvido em uma plataforma que permite a integração com outros modelos como, por exemplo, o Sistema AcquaNet. A integração futura pode trazer alguns benefícios quando se deseja avaliar um grande número de demandas quantitativas.

O instrumento de outorga para lançamento de efluentes apresenta importante papel na gestão da qualidade da água e na solução de conflitos de uso, assim sendo, destaca-se a necessidade de divulgação e discussão do instrumento e das estratégias a serem implantadas junto aos órgãos gestores e usuários da bacia.

A efetivação da Política Nacional de Recursos Hídricos está diretamente relacionada com a integração dos instrumentos de gestão, no entanto, esta integração ainda não é muito visualizada nos aspectos práticos. A adoção de metodologias, critérios e estratégias que possibilitem a integração dos instrumentos de gestão, como os apresentados no SSD desenvolvido, contribuem significativamente para a efetivação dos objetivos da PNRH. Assim sendo, recomenda-se a aplicação desta ferramenta de gestão para auxiliar as análises de outorga de efluentes, onde são consideradas as metas estabelecidas pelo enquadramento dos corpos hídricos, representando a integração dos instrumentos de gestão propostos pela Lei 9.433/97. 


\section{REFERÊNCIA BIBLIOGRÁFICA}

ANA. AGÊNCIA NACIONAL DE ÁGUAS. Cadernos de Recursos Hídricos: Diagnóstico da Outorga de Direito de Uso de Recursos Hídricos no País. Diretrizes e Prioridades. Brasília: ANA, 2005. Disponível em: <http://www.ana.gov.br>. Acesso em 15 de novembro de 2006.

Cadernos de Recursos Hídricos 4: Diagnóstico da Outorga de Direito de Uso de Recursos Hídricos. Fiscalização dos Usos de Recursos Hídricos no Brasil. Brasília: ANA, 2007. Disponível em: <http://www.ana.gov.br>. Acesso em maio de 2008.

Conjuntura dos recursos hídricos no Brasil 2009. Brasília: ANA, 2009. Disponível em: $<$ http://www.ana.gov.br>. Acesso em 11 de Agosto de 2009.

. Conjuntura dos recursos hídricos no Brasil 2010. Brasília: ANA, 2010. Disponível em: <http://www.ana.gov.br>. Acesso em 04 de Novembro de 2010.

BRASIL. Ministério do Meio Ambiente. Plano Nacional de Recursos Hídricos. Panorama e estado dos recursos hídricos do Brasil - Volume 1 / Ministério do Meio Ambiente, Secretaria de Recursos Hídricos. MMA, 2006.

Ministério do Meio Ambiente. Conselho Nacional de Recursos Hídricos. Resolução n: 12, de 19 de junho de 2000. Brasília, 2000.

. Ministério do Meio Ambiente. Conselho Nacional de Recursos Hídricos. Resolução no 16 do CNRH, de 08 de Maio de 2001. Publicada no D.O.U de 14 de Maio de 2001.

Ministério do Meio Ambiente. Secretaria de Recursos Hídricos. Política Nacional de Recursos Hídricos. Lei no 9.433, de 8 de janeiro de 1997. Brasília, 1997.

Ministério do Meio Ambiente. Secretaria de Recursos Hídricos. Política Nacional de Recursos Hídricos. Lei no 9.433, de 8 de janeiro de 1997. Brasília, 1997.

Ministério das Cidades, 2010. O Setor de Saneamento e Perspectiva do O Setor de Saneamento e Perspectiva do Programa de Aceleração do Programa de Aceleração do Crescimento - PAC Crescimento - PAC, 2010.

BRITES, A. P. Z. Enquadramento dos Corpos de Água Através de Metas Progressivas: Probabilidade de Ocorrência e Custos de Despoluição Hídrica. Tese apresentada à Escola Politécnica da Universidade de São Paulo na Área de Concentração: Recursos Hídricos, São Paulo, Estado de São Paulo, 2010.

CARDOSO DA SILVA, L. M. Cobrança pelo Uso de Recursos Hídricos para Diluição de Efluentes. Anais do XVII Simpósio Brasileiro de Recursos Hídricos, São Paulo, 2007.

CHAKRABORTY, U. K. et al. 2008 Advances in Differential Evolution. Springer -Verlag Berlin Heidelberg.

CHANG, N. B., CHEN, W. C.,AND SHIEH, W. K. 2001. "Optimal control of wastewater treatment plants via integrated neural network and genetic algorithms." Civil Engineering.Environmental .Systems.,18(1),1-17.

CHAPRA, S. C. Surface Water Quality Modeling. USA: McGraw-Hill, 1997. 844p. 
CHEN, W. C., CHANG, N. B.,AND CHEN, J. C. 2003.“Roughset-based hybrid fuzzy-neural controller design for industrial wastewater treatment." Water Resource.,37 (1),95-107.

COLLISCHONN, W., AGRA, S. G., FREITAS,G. K., PRIANTE, G. R., TASSI, R., SOUZA, C. F., Em Busca do Hidrograma Ecológico, XVI Simpósio Brasileiro De Recursos Hídricos, João Pessoa, PB, 2005.

CRUZ, J.C. Disponibilidade Hídrica para Outorga: Avaliação de Aspectos Práticos e Conceituais. 2001. 205p. Tese (Doutorado do Programa em Engenharia de Recursos Hídricos e Saneamento Ambiental) - Instituto de Pesquisas Hidráulicas, Universidade Federal do Rio Grande do Sul, Porto Alegre, 2001.

CRUZ, J. C., SILVeIRA, G. L. da, SILVEIRA, A. L. L. da, CRUZ, R. C. Avaliação da disponibilidade hídrica para outorga sistemática modular de avaliação. In: Simpósio de Hidráulica e Recursos Hídricos dos Países de Língua Portuguesa, 4, Coimbra, Portugal, 1999.

CUNHA C. B. Contribuição à modelagem de problemas em logística e transportes. Tese (Livre-Docência) - Escola Politécnica da Universidade de São Paulo. Departamento de Engenharia de Transportes. São Paula, 2006.

DAEE, Departamento de Águas e Energia Elétrica. Balanço Hídrico Critérios e Procedimentos, 2003.

DEB, K. 1999 An introduction to genetic algorithms. Sadhana. 24 (4), 293-315.

DEB, K. 2001 Genetic Algorithm. Kanpur Genetic Algorithms Laboratory. (http://www.iitk.ac.in/kangal/codes.shtml).

DEB, K. e BEYER H.-G. 2001 Self-Adaptive Genetic Algorithms with Simulated Binary Crossover. Evolutionary Computation. 9 (2) - Massachusetts Institute of Technology.

EUCLYDES, H. P., FERREIRA, P. A., FARIA FILHO, R. F. Critério de outorga sazonal para a agricultura irrigada no estado de minas gerais. Estudo de caso. Revista ITEM - Irrigação \& Tecnologia Moderna, ํㅡ 71/72, 3ำ e 4ำ Trimestres 2006.

FERRAZ, A. R. G., BRAGA Jr, P. F. Modelo decisório para a outorga de direito ao usos da água no Estado de São Paulo. Revista Brasileira de Recursos Hídricos - RBRH, v. 3, n. 1, 1998.

GARCIA, J. I. B., PORTO, R. L. L., MARCELLINI, S. S., GARCIA, L. A. V., ROBERTO, A. N., Avaliação da Disponibilidade Hídrica para a Concessão de Outorga Através de Modelo de Suporte à Decisão - Aplicação na Bacia do Turvo no Estado de São Paulo, in Anais do XVII Simpósio Brasileiro de Recursos Hídricos, São Paulo, 2007.

GOLDBERG, D. E. 1989 Genetic Algorithms in Search, Optimization and Machine Learning, Addision-Wesley, New York.

GURIA, C., BHATTACHARYA, P. K., GUPTA, S. K. 2005. "Multi-objective optimization of reverse osmosis desalination units using different adaptations of the non-dominated sorting genetical gorithm NSGA." Computers \& Chemical Engineering., Elsevier 29(9),1977-1995.

HORA, A. F. Metodologia para outorga do uso de recursos hídricos com ênfase no caso de aproveitamentos hidrelétricos. 2001. 256 f. Tese (doutorado em ciências em engenharia de produção) - Universidade Federal do Rio de Janeiro. Rio de Janeiro, 2001. 
KELMAN, J. Gerenciamento de recursos hídricos; parte 1: outorga. In: Simpósio Brasileiro de Recursos Hídricos, Vitória, 1997.

KELMAN, J. 1997. Gerenciamento de Recursos Hídricos: Outorga e Cobrança. Anais do XII Simpósio Brasileiro de Recursos Hídricos. Vitória - ES.

KENNEDY, J. e EBERHART, R. 1995 Particle Swarm Optimization. Proc. 4th IEEE Int. Conf. on Neural Networks, IEEE, Piscataway, NJ, 1942 - 1948, 1995.

KONDAGESKI, J. H. FERNANDES, C.V.S. Proposta de Calibração de um Modelo Multiparâmetro de Qualidade da Água Utilizando o Algoritmo Genético. Anais do XVII Simpósio Brasileiro de Recursos Hídricos, São Paulo, 2007.

LABADIE, J. W., "Dynamic Programming with the Microcomputer," in Encyclopedia of microcomputers, Vol. 5, A. Kent and J. Williams, eds., Marcel Dekker Inc., New York, 1990.

LABADIE, J. W. (1998). Descision support systems applied to water resorurces engineering, Curso promovido pela SABESP_EPUSP, São Paulo, 1998.

LABADIE, J. W., GENERALIZED DYNAMIC PROGRAMMING PACKAGE: CSUDP, Documentation and User Guide Version 2.44, 2003

LACERDA, E. G. M. de; CARVALHO, A. C. P. L. F. de. Introdução aos algoritmos genéticos. In: Galvão, C. de O.; Valença, M.J.S. (orgs.). Sistemas inteligentes: aplicações a recursos hídricos e ciências ambientais: Porto Alegre: Ed. Universidade/UFRGS, 1999.

LANNA, A. E. et al. SAGBAH - Sistema de Apoio ao Gerenciamento de Bacias Hidrográficas - Manual Básico, 2005.

LAVRIC, V., IANCU, P., e PLESU, V. 2005. "Genetic algorithm optimization of water consumption and wastewater network topology." Journal of Cleaner Production - Elsevier, 13 (15), $1405-1415$.

LEEUWESTEIN, J. M. Proposição de suporte metodológico para enquadramento de cursos de água, 2000. xv, 201p. Dissertação de Mestrado - Universidade de Brasília. Faculdade de Tecnologia. Departamento de Engenharia Civil e Ambiental.

LOUCKS, D. P; BEEK, E. V. Water Resources Systems Planning and Management An Introduction to Methods, Models and Applications. United Nations Educational Scientific and Cultural Organization. ISBN 92-3-103998-9, UNESCO 2005 and WL/ Delft Hydraulics 2005.

MENDES, L. A. (2007). Análise dos Critérios de Outorga de Direito de Usos Consuntivos dos Recursos Hídricos Baseados em Vazões Mínimas e em Vazões de Permanência. Dissertação de Mestrado apresentada à Escola Politécnica da Universidade de São Paulo para obtenção do título de Mestre em Engenharia na Área de Concentração: Recursos Hídricos, São Paulo, Estado de São Paulo, 2007, p. 183.

MENEGON, N. J. Aplicação do modelo Matemático de Qualidade de Água - SIMOX-III na Bacia do Rio Camanducaia. 164p. Dissertação (Mestrado). Escola Politécnica da Universidade de São Paulo. Departamento de Engenharia Hidráulica e Sanitária. São Paulo, 2005.

MMA (Ministério do Meio Ambiente). Secretaria de Recursos Hídricos (SRH/MMA). SISAGUA - Sistemas de Apoio Ao Gerenciamento de Usuários da Água. Brasília, 2000. 
MULLIGAN, A. E.; BROWN, L. C. Genetic Algorithms For Calibrating Water Quaity Models. Journal of Environmental Engineering. Vol 124, N0. 3, Março 1998.

NAHON, I. M; KISHI, R. T; FERNANDES, C. V. S. Desenvolvimento de um Sistema de Apoio à Análise de Outorga de Lançamento de Efluentes - Estudo de Caso: Bacia do Alto Iguaçu. Revista Brasileira de Recursos Hídricos - RBRH, v. 14, n. 2, 2009. pp. 47 - 58p.

NICKLOW, J.; REED, P.; SAVIC, D.; DESSALEGNE, T.; HARRELL, L.; CHAN-HILTON, A.; KARAMOUZ, M.; MINSKER, B.; OSTFELD, A.; SINGH, A.; ZECHMAN, E. State of the Art for Genetic Algorithms and Beyond in Water Resources Planning and Management. Journal of Water Resources Planning and Management @ ASCE / July/August 2010.

NUNES, C. M.; LIBÂNIO, P. A. C.; SOARES, S. R. A. Custos Unitários de Implantação de Estações de Tratamento de Esgotos a partir da Base de Dados do Programa Despoluição de Bacias Hidrográficas - PRODES. In: 23ํㅡㄹ Congresso Brasileiro de Engenharia Sanitária e Ambiental, 2005, Campo Grande - MS. 2005.

PARANASAN - SANEPAR. Plano Diretor de Abastecimento de Água - Sistema Integrado de Abastecimento de Água de Curitiba - Revisão do Plano Diretor (Geotécnica) 1991. UGP PARANASAN - SANEPAR, 2000.

PORTO, R. L; AZEVEDO, L. G. T. Sistema de Suporte a Decisão Aplicado a Problemas de Recursos Hídricos. In: Técnicas quantitativas para o gerenciamento de recursos hídricos. Org. por Porto, R. L., ABRH, ed. UFRGS, Porto Alegre - RS, 1997. pp. 43 - 95p.

PORTO, M. F. A. Sistemas de Gestão da Qualidade das Águas: Uma Proposta para o Caso Brasileiro. Tese (Livre-Docência) - Escola Politécnica da Universidade de São Paulo. Departamento de Engenharia Hidráulica e Sanitária, São Paulo, 2002. 131p.

PORTO, M. F. A. As Interfaces entre os Processos de Licenciamento Ambiental e Outorga pelo Uso da Água, Mesa Redonda 10, XVIII Simpósio Brasileiro De Recursos Hídricos, Campo Grande, MS, 2009, disponível em http://www.abrh.org.br/xviiisbrh/download.php, último acesso 20/05/2010.

PORTO, R. L. et al. Sistema de suporte a decisão para análise de sistemas de recursos hídricos. In: Métodos Numéricos em Recursos Hídricos 6. Org. por da Silva, R. C. V., ABRH, ed. UFRGS, Porto Alegre - RS, 2003. pp. $93-240$ p.

PORTO, R. L. L., MELLO JR, A. V., ROBERTO A. N., R. B., Plataforma Generalizada para Análise de Outorga para Captação de Água e para Lançamento de Efluentes. In: I Simpósio de Recursos Hídricos do Sul-Sudeste, Curitiba - PR, 2006.

PRICE, K. V., STORN, R. M. e LAMPINEN, J. A. 2005 Differential evolution: A practical approach to global optimization. Springer, Berlin, Heidelberg.

PRICE, K. V. e STORN, R. M. 1997 Differential evolution - A simple evolution strategy for fast optimization. Dr. Dobb's Journal. 22, 18-24.

PROJETO IGUAÇU - Análise da Sustentabilidade Econômica e Ambiental de Metas de Despoluição Hídrica - Estudo de Caso: Alto Iguaçu, Volume 1/6 - Relatório Final. Fevereiro/2005. 
PROSAM - Programa de Saneamento Ambiental da Região Metropolitana de Curitiba Secretaria de Planejamento, Governo do Estado do Paraná, 1991.

RIBEIRO, M. M. R., LANNA, A. E. L. A outorga Integrada das Vazões de Captação e Diluição. Revista Brasileira de Recursos Hídricos. Vol. 8, n³, p. 151-168, 2003.

RODRIGUES, R. B., CARDOSO DA SILVA, L. M. ALOC Server - Sistema De Alocação de Carga e de Vazão de Diluição para os Processos de Enquadramento, Outorga e Cobrança pelo uso dos Recursos Hídricos. In: XVII Simpósio Brasileiro de Recursos Hídricos, São Paulo/SP, 2007.

RODRIGUES, R. B., PORTO, M. Modelo matemático proposto para auxílio nos processos de outorga e cobrança pelo uso da água. In: Simpósio Brasileiro de Recursos Hídricos XIII, Belo Horizonte - MG, 1999.

RODRIGUES, R. B. Metodologia de apoio à concessão de outorga para diluição de efluentes e cobrança pelo uso da água - o modelo RM1. 2000. 140 p. Dissertação (Mestrado em engenharia civil) - Universidade de São Paulo, São Paulo, 2000.

RODRIGUES, R. B. SSD RB - Sistema de Suporte a Decisão Proposto para a Gestão QualiQuantitativa dos Processos de Outorga e Cobrança pelo Uso da Água. 155 p. Tese (Doutorado) Escola Politécnica da Universidade de São Paulo. Departamento de Engenharia Hidráulica e Sanitária. São Paulo, 2005.

ROQUES, T. V. P., Aplicação de modelos computacionais na análise de outorga para diluição de efluentes em corpos de água - fontes pontuais e difusas. Dissertação de Mestrado, Universidade Federal do Espírito Santo UFES, 2006.

SAMARANO, S. F. P; PRADO, J. R. Otimização por Colônia de Partículas. Famat Em Revista, UFU, v. 04, p. 87-103, 2005.

SHI, Y. e EBERHART, R. C. A modified particle swarm optimizer. Proceedings of the IEEE Congress on Evolutionary Computation (CEC 1998), Piscataway, NJ, p. 69-73, 1998.

CARDOSO DA SILVA, L. M., MONTEIRO, R. A. Outorga de Direito de Uso de Recursos Hídricos: Uma das Possíveis Abordagens. In: Carlos José Saldanha Machado. (Org.). Gestão de Águas Doces. 1 ed. Rio de Janeiro: Interciência, 2004, v. 1, p. 135-178.

SILVA, L. M., LANNA, A. E., A outorga dos direitos de uso da água no cerrado baiano. In: Simpósio de Recursos Hídricos do Nordeste 3, 1996, Salvador, Anais Salvador ABRH, p 343-348.

SILVEIRA, G. L. et al. Outorga para uso dos recursos hídricos: aspectos práticos e conceituais para o estabelecimento de um sistema informatizado. Revista Brasileira de Recursos Hídricos. Vol. 3, n³, p. 5-16, 1998.

SIMONOVIC, S. P. 2008 Managing Water Resources - Methods and Tools for a Systems Approach. UNESCO Publishing.

SOBRINHO, P. A. Tratamento de esgoto - Concepções básicas, geração de lodo, consumo de energia e custos de implantação. Notas de Aula, 2005.

SELVAKUMAR, A.. BMP's Cost. In: The use of best management practices (BMP) in urban watersheds. USA: Environmental Protection Agency. Office of Research and Development, Washington DC 20460. EPA/600/R-04/184, 2004. 271p. 
SOWINSKI, M; NEUGEBAUER, A. Calibration of Water-Quality Model "Woda" - Case Study of the Warta River. Journal of Environmental Engineering and Landscape Management. , Vol XV, No 2, 93-98, 2007.

STRON, R. M. e PRICE, K. V. 1995 Differential Evolution - A simple and efficient adaptive scheme for global optimization over continuous spaces. Technical Report TR-95-012, ICSI.

SUGGALA, S. V., E BHATTACHARYA, P. K. 2003. "Real coded genetic algorithm for optimization of pervaporation process parameters for removal of volatile organics from water." Industry Engineering Chemical Research ACS., 42(13), 3118-3128.

TEIXEIRA, C. A., Gerenciamento Integrado de Quantidade e Qualidade de Água. Tese (Doutorado) - Escola Politécnica da Universidade de São Paulo. Departamento de Engenharia Hidráulica e Sanitária. São Paulo, 2004.

TSAI, M. J., e CHANG, C. T. 2001. "Water usage and treatment network design using genetical gorithm." Industry Engineering Chemical Research ACS., 40, 4874- 4888.

TUCCI, C. E. M. Modelos Hidrológicos. Ed. Universidade/UFRGS/Associação Brasileira de Recursos Hídricos- ABRH. Porto Alegre:, 1998, 669p.

TUCCI, C. E. M. 2009 (18 de Outubro de 2009, BALANÇO HÍDRICO, Blog do Tucci, http://blog.rhama.net/2009/10/.

VASAN A. e SIMONOVIC S. P. (2008). Optimization Using Differential Evolution. Water Resources Research Report no. 060, Facility for Intelligent Decision Support, Department of Civil and Environmental Engineering, London, Ontario, Canada, 38 pp.

VON SPERLING, M. Introdução à qualidade das águas e ao tratamento de esgotos. 3. ed., Belo Horizonte: Departamento de Engenharia Sanitária e Ambiental; Universidade Federal de Minas Gerais, 2005. 243 p. (Princípios do tratamento biológico de águas residuárias, v. 1).

YEH, W. W-G. Reservoir management and operation models: a state-of-the-art review. Journal Water Resources Planning and Management, v. 21, n. 12, p. 1797-1818, 1985.

WURBS, R. A. 1995. Water Rights in Texas. Journal of Water Resource Planning and Management. v.121, n. 6, p.447.

WURBS, R. A. e WALLS, W. B., 1989. Water Rights Modeling and Analysis. Journal of Water Resources Planning and Management. v.115, n.4, p. 416-430. 
10 - ANEXOS 


\subsection{ANEXO I - Interface do SSD proposto}

Para atingir os objetivos desta tese está sendo desenvolvida uma interface gráfica que permita ao usuário do modelo estruturar a rede hídrica de forma simples. Esta interface está sendo desenvolvida em VB.NET e permite ao usuário a entrada de dados, execução dos algoritmos propostos e visualização dos resultados em forma de tabelas e gráficos. A seguir serão apresentadas as diferentes telas do modelo e suas funcionalidades.

A Figura 10.1apresenta a tela inicial do modelo, onde podem ser visualizadas duas abas principais. A aba esquerda contendo informações gerais como: descrição, número de trechos a serem simulados, seleção dos parâmetros a serem simulados, além dos botões de acesso às telas de entrada de dados e visualização de resultados. $\mathrm{Na}$ aba direita pode ser visualizado o gerenciador para a otimização da calibração automática e otimização dos lançamentos de efluentes.

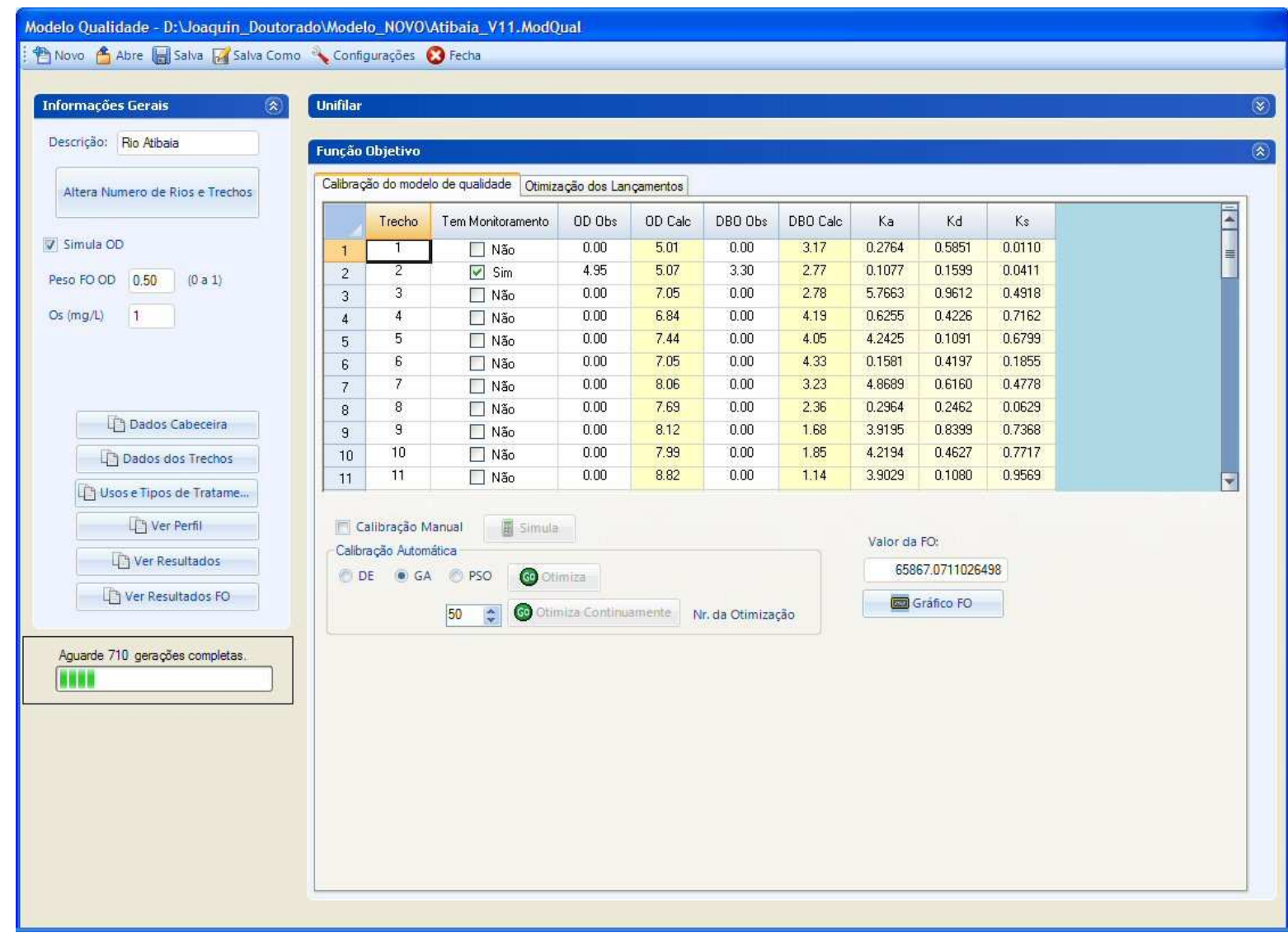

Figura 10.1 - Tela inicial do modelo habilitado para o modulo de calibração do modelo de qualidade

$\mathrm{Na}$ Figura 10.2pode ser visualizada a tela principal do modelo habilitada para a otimização do lançamento de efluentes. Nesta tela são apresentados os valores dos 
lançamentos de efluentes, os valores mínimos e máximos de tratamento para cada efluente, o tratamento obtido com o algoritmo de otimização e os resultados para os parâmetros de OD e DBO.

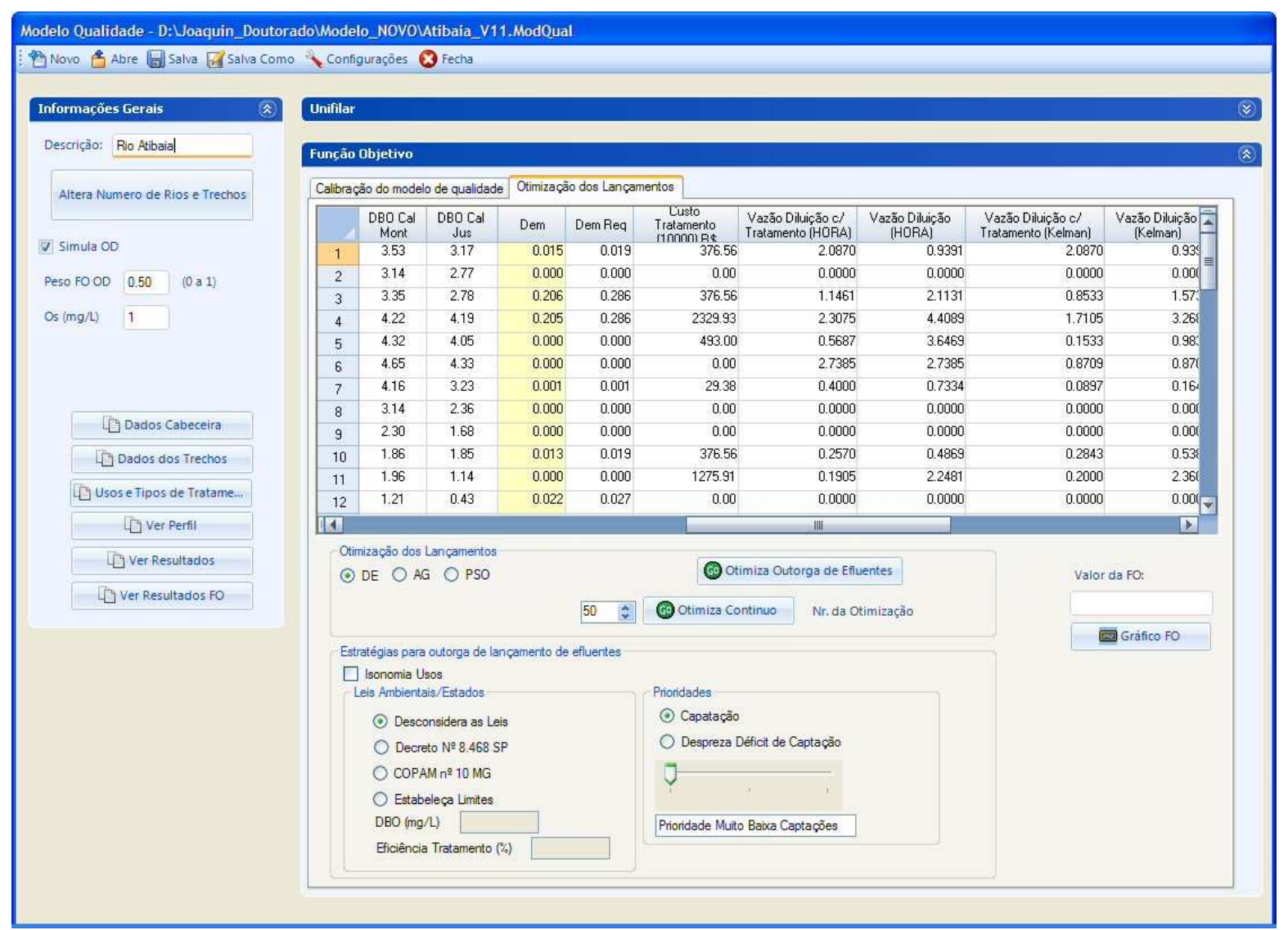

Figura 10.2 - Tela inicial do modelo habilitado para o modulo de otimização de lançamentos

A Figura 10.3 apresenta a tela de entrada de dados dos cursos d'água e trechos a serem simulados, nesta tela o usuário deve indicar o número de rios e a ordem de cada rio assim como o trecho de entrada de cada afluente. 


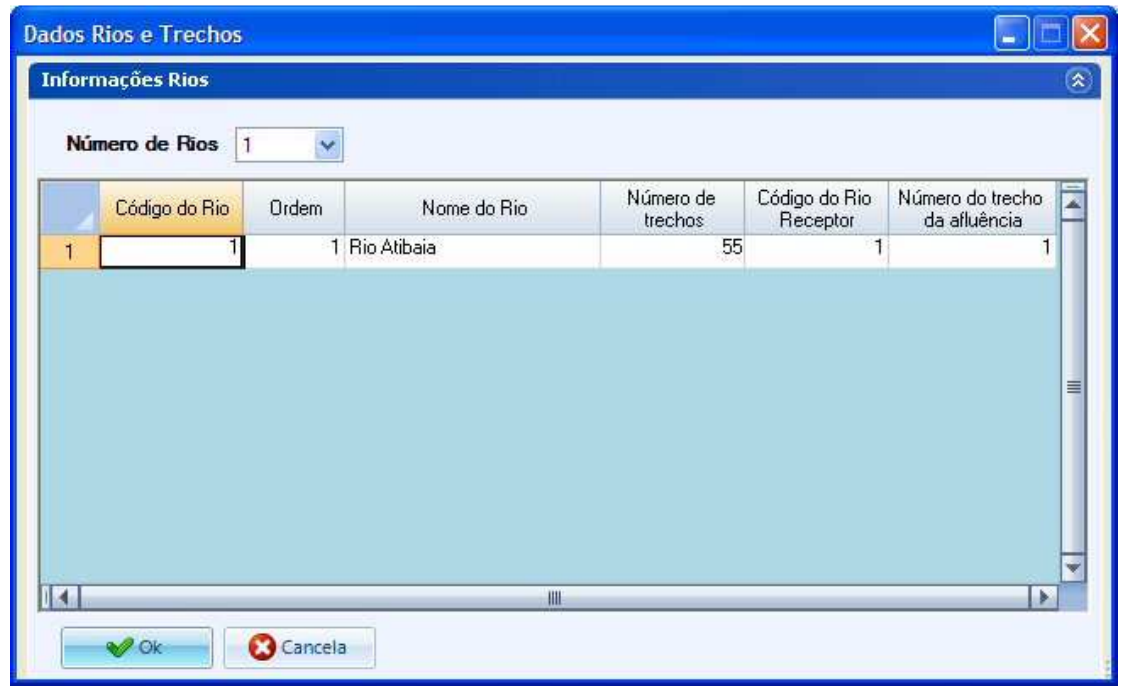

Figura 10.3 - Tela de entrada de dados dos cursos d'água a serem simulados

A Figura 10.4 apresenta a tela como os botões para de acesso a entrada de dados e visualização dos resultados.

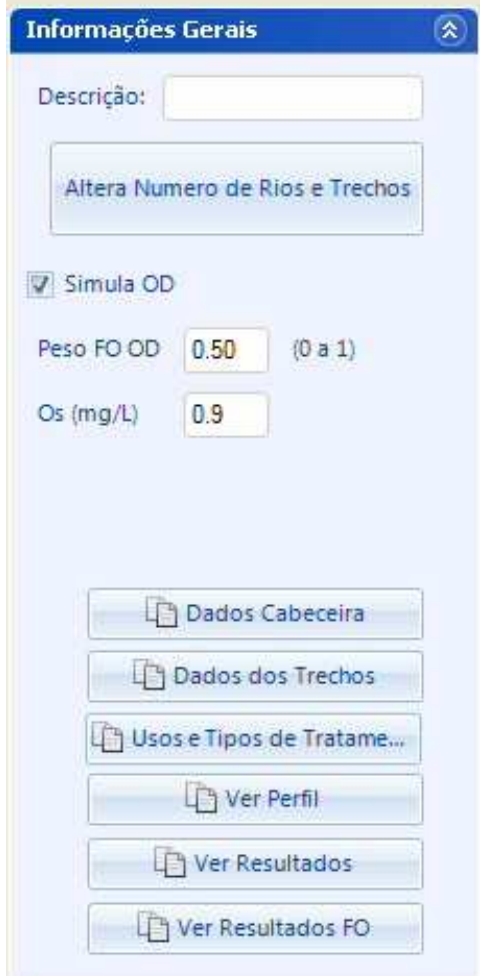

Figura 10.4 - Botões para a entrada de dados e visualização de resultados

A Figura 10.5 apresenta a tela de entrada de dados dos parâmetros dos algoritmos utilizados nos SSD. 


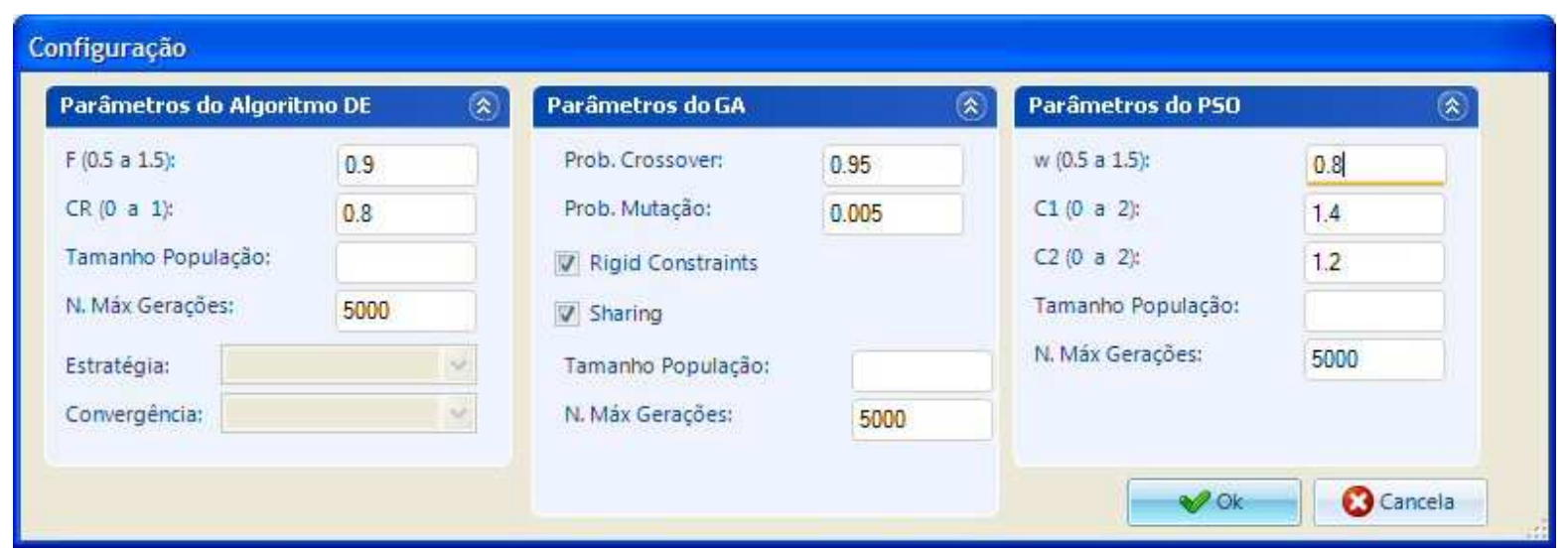

Figura 10.5 - Teta entrada de dados dos parâmetros dos algoritmos

A Figura 10.6 apresenta a tela de entrada de dados da cabeceira do curso d'água a ser analisado.

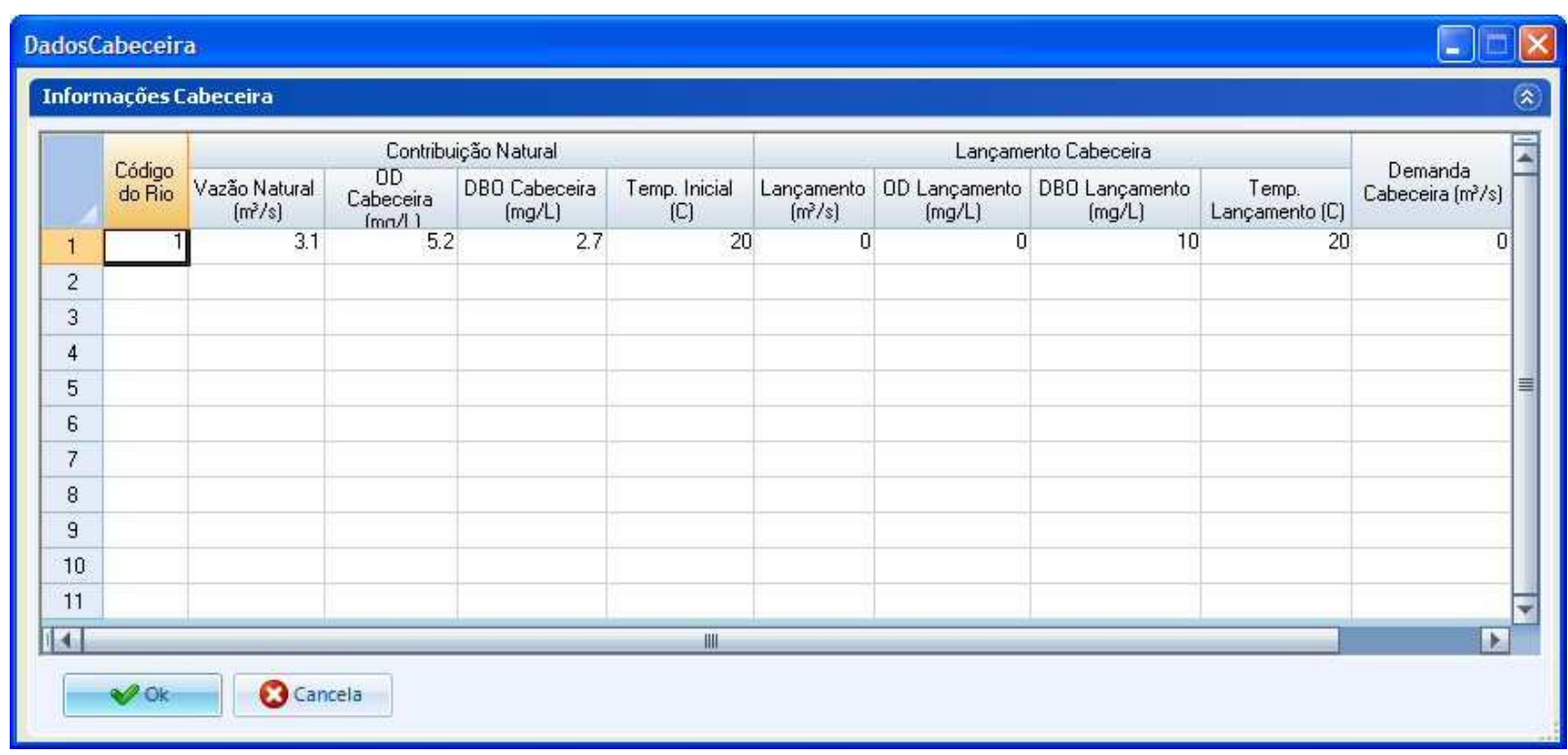

Figura 10.6 - Informações da cabeceira

Na Figura 10.7 pode ser visualizada a tabela de dados de entrada do modelo para as captações, lançamentos e vazão natural. 


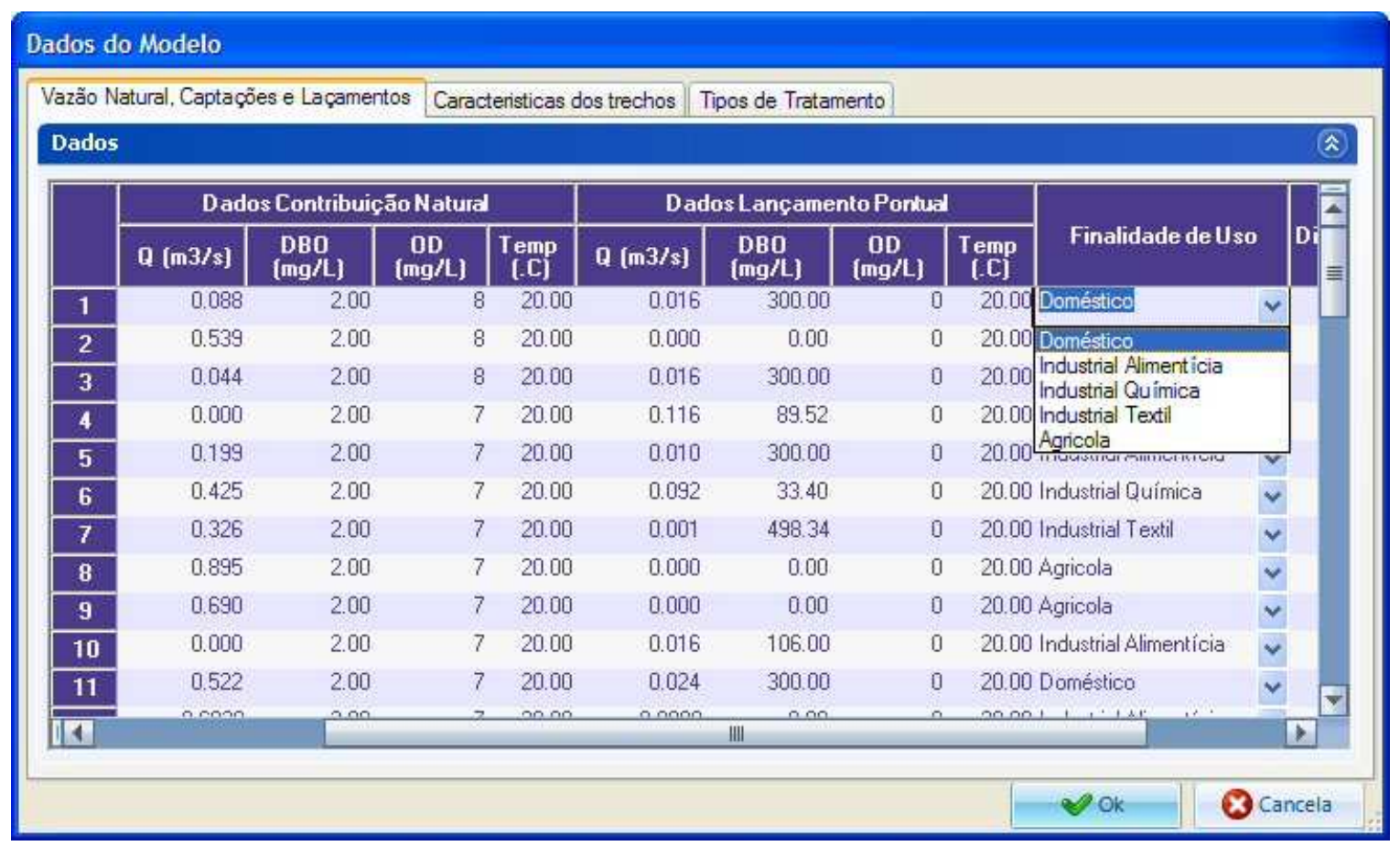

Figura 10.7 - Dados de entrada de vazão natural, captações e lançamentos

$\mathrm{Na}$ Figura 10.8 pode ser visualizada a tabela de dados de entrada para as características dos trechos, assim como os valores mínimos e máximos para os coeficientes.

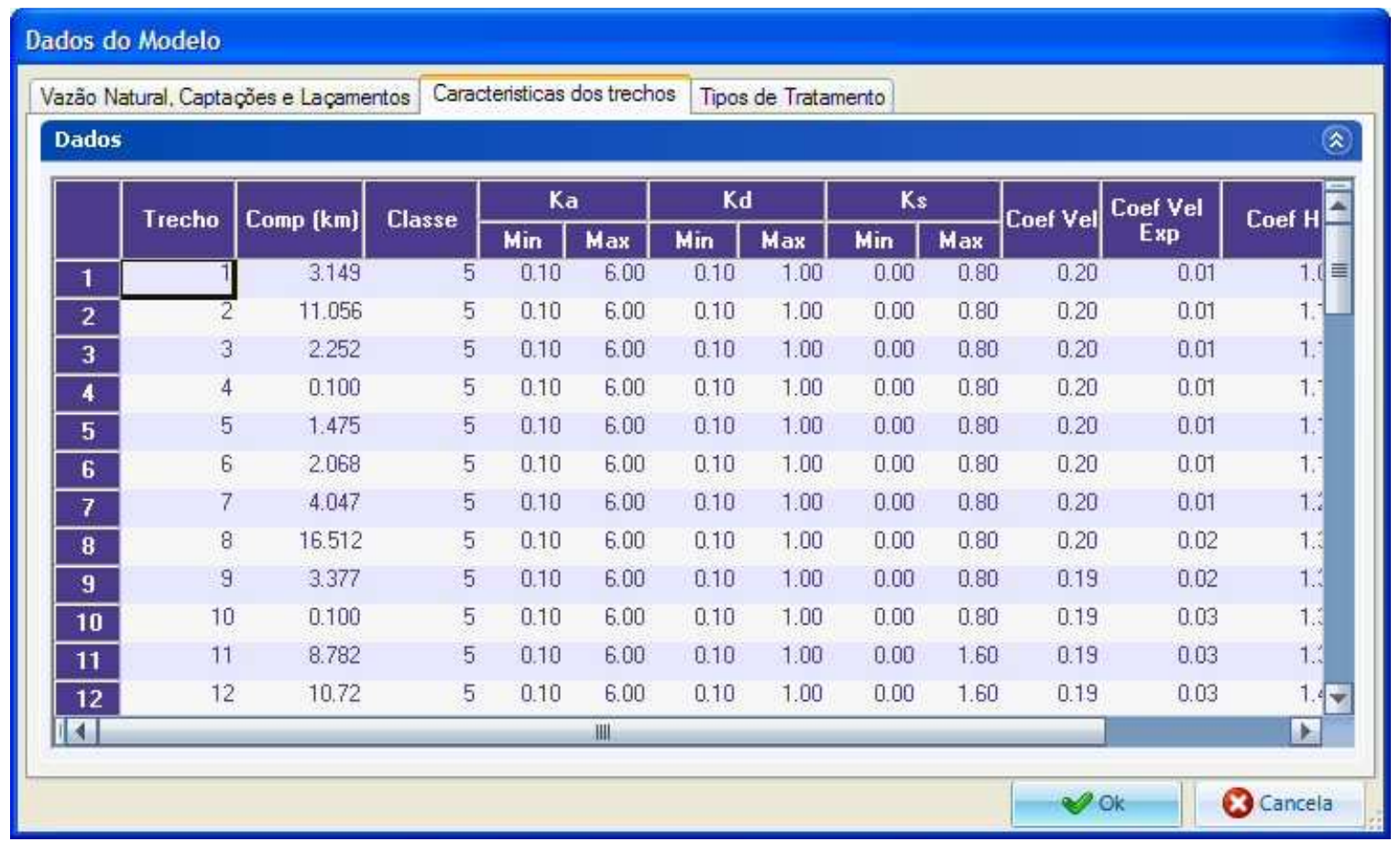

Figura 10.8 - Dados de entrada características dos trechos e coeficientes de decaimento

Na Figura 10.9 pode ser visualizada a tabela de dados de entrada para as finalidades de uso, tipos de uso, e as eficiências mínima e máxima de tratamento por finalidade de uso. 


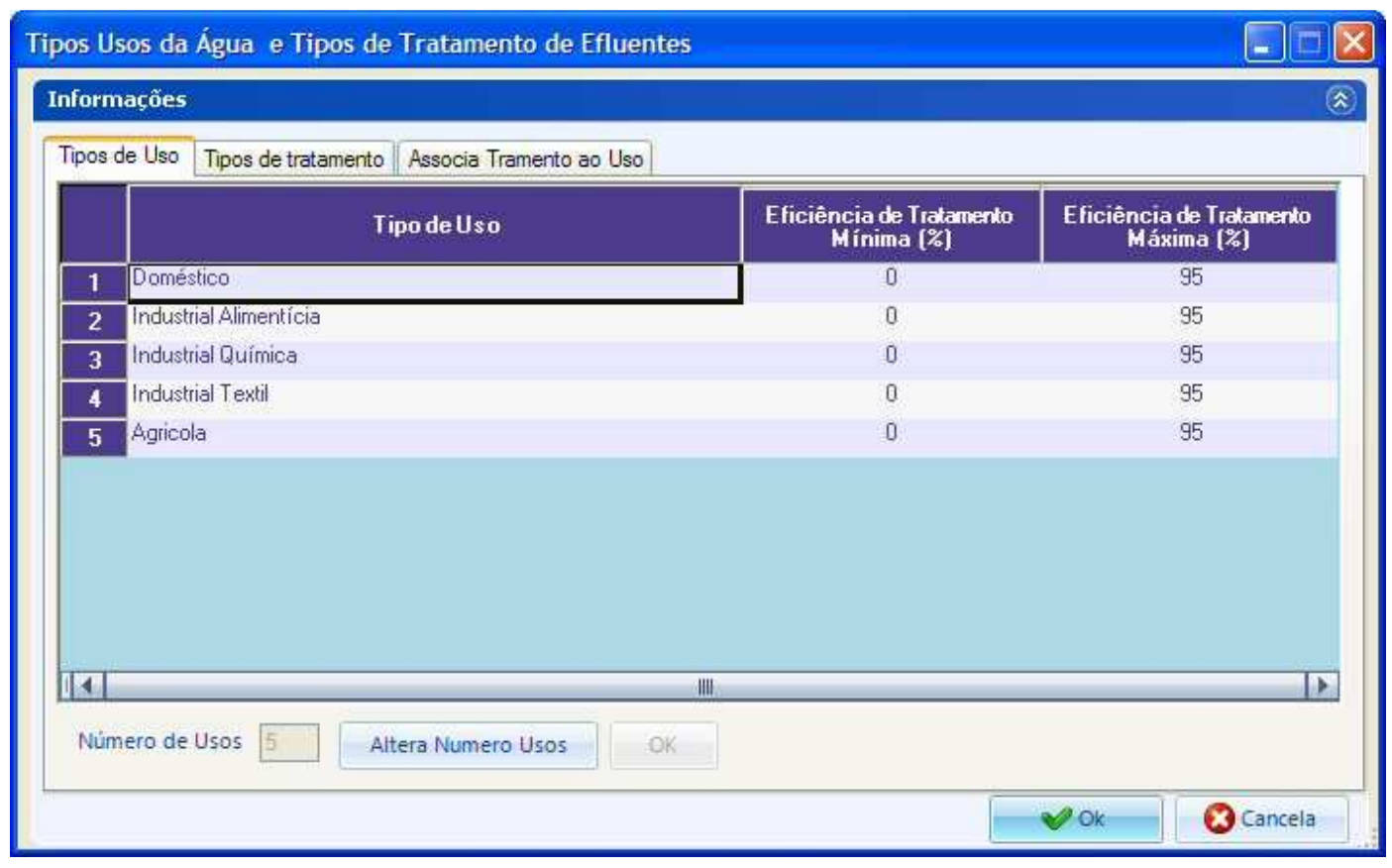

Figura 10.9 - Dados de entrada dos tipos de uso da bacia - Finalidades de uso

Na Figura 10.10 pode ser visualizada a tabela de dados de entrada para as estação de tratamento de efluentes e sua função de custo e eficiência de remoção de carga.

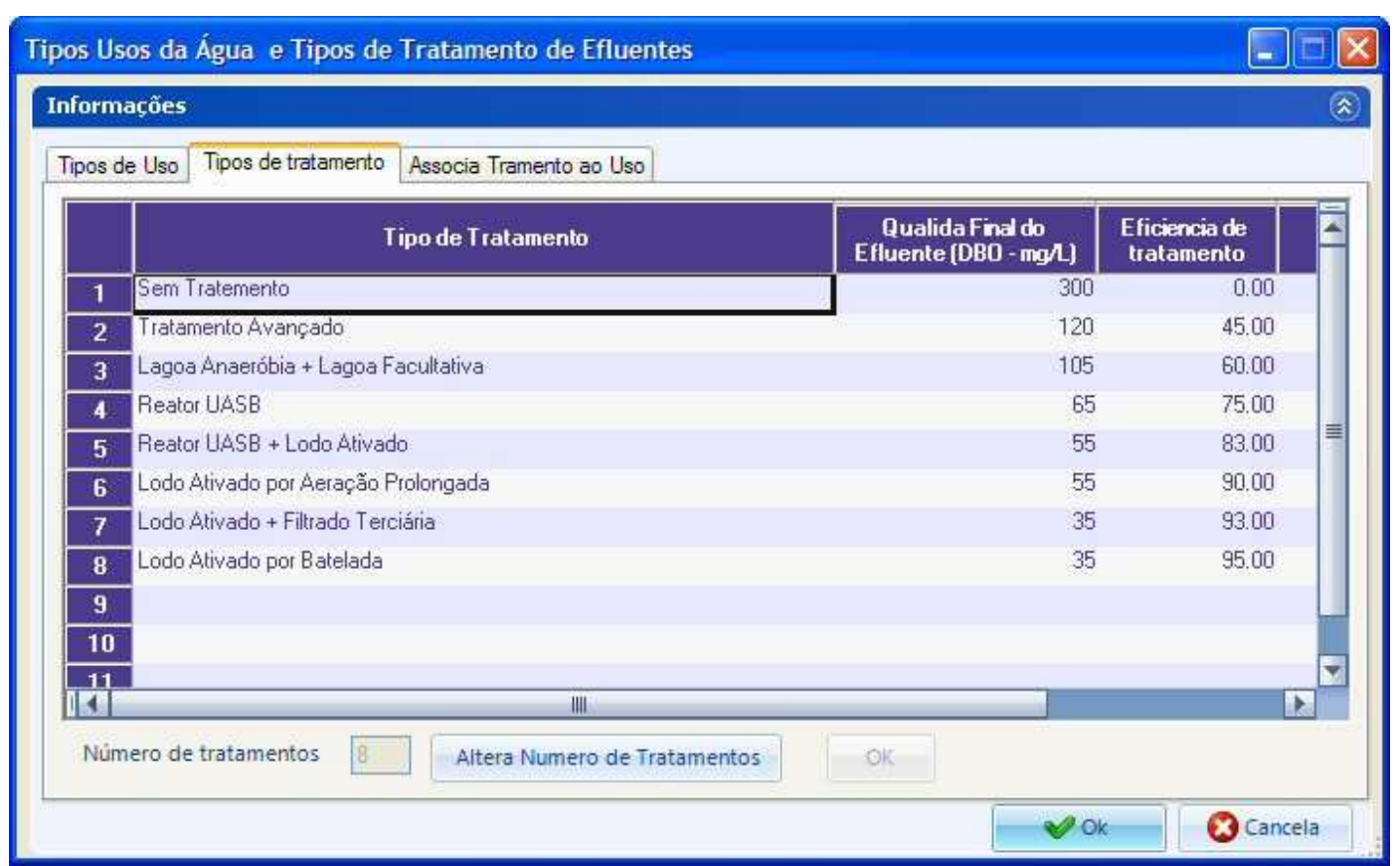

Figura 10.10 - Dados de entrada dos tipos de tratamento e respectivas funções de custo e eficiências de tratamento

Na Figura 10.11 pode ser visualizada a tabela de dados de entrada para as estação de tratamento de efluentes e sua função de custo e eficiência de remoção de carga. 


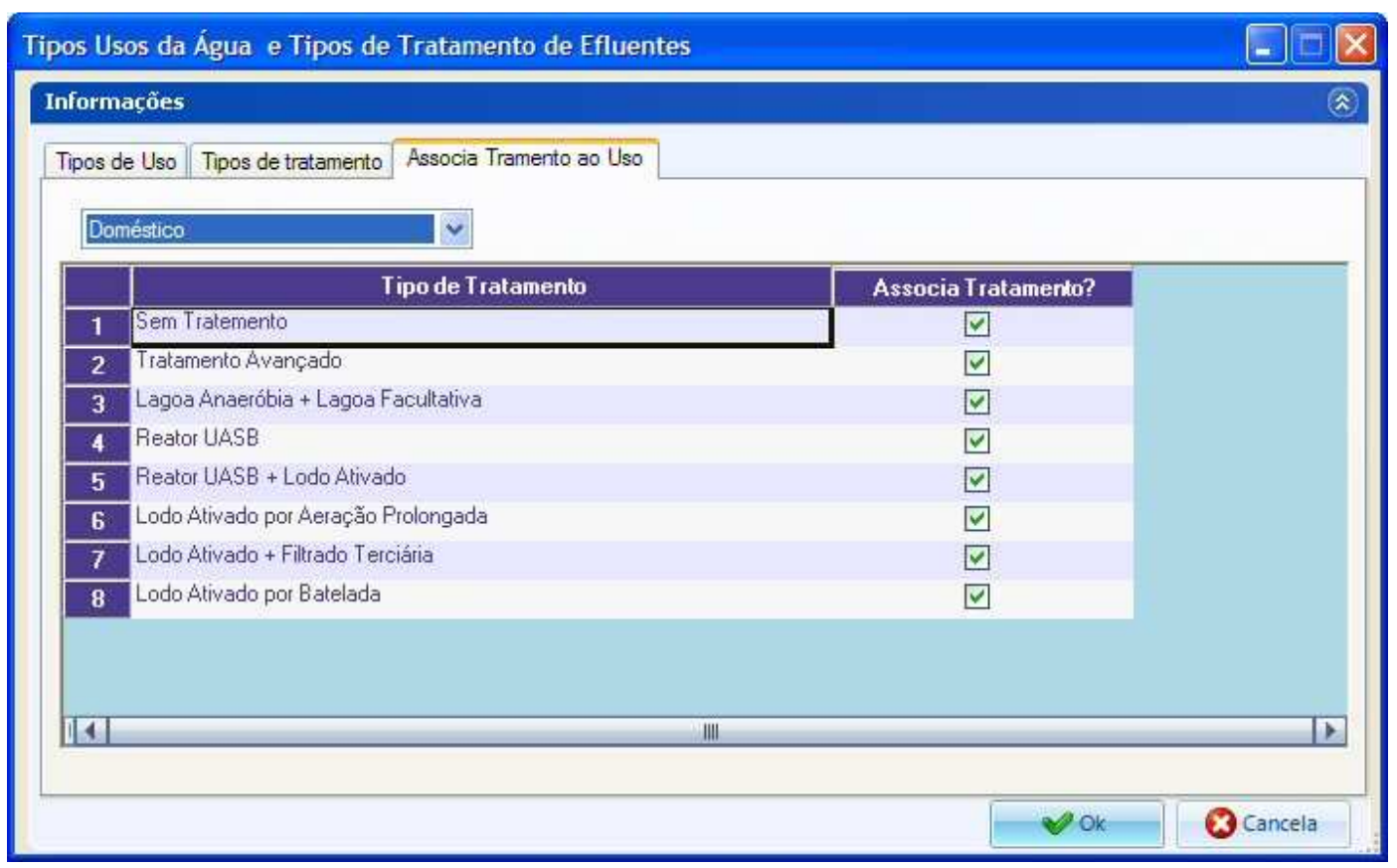

Figura 10.11 - Tela de associação dos tipos de tratamentos com as finalidades de uso

$\mathrm{Na}$ Figura 10.12 podem ser visualizados os valores de OD e DBO obtidos para os trechos e o gráfico com o perfil de qualidade para o trecho analisado.

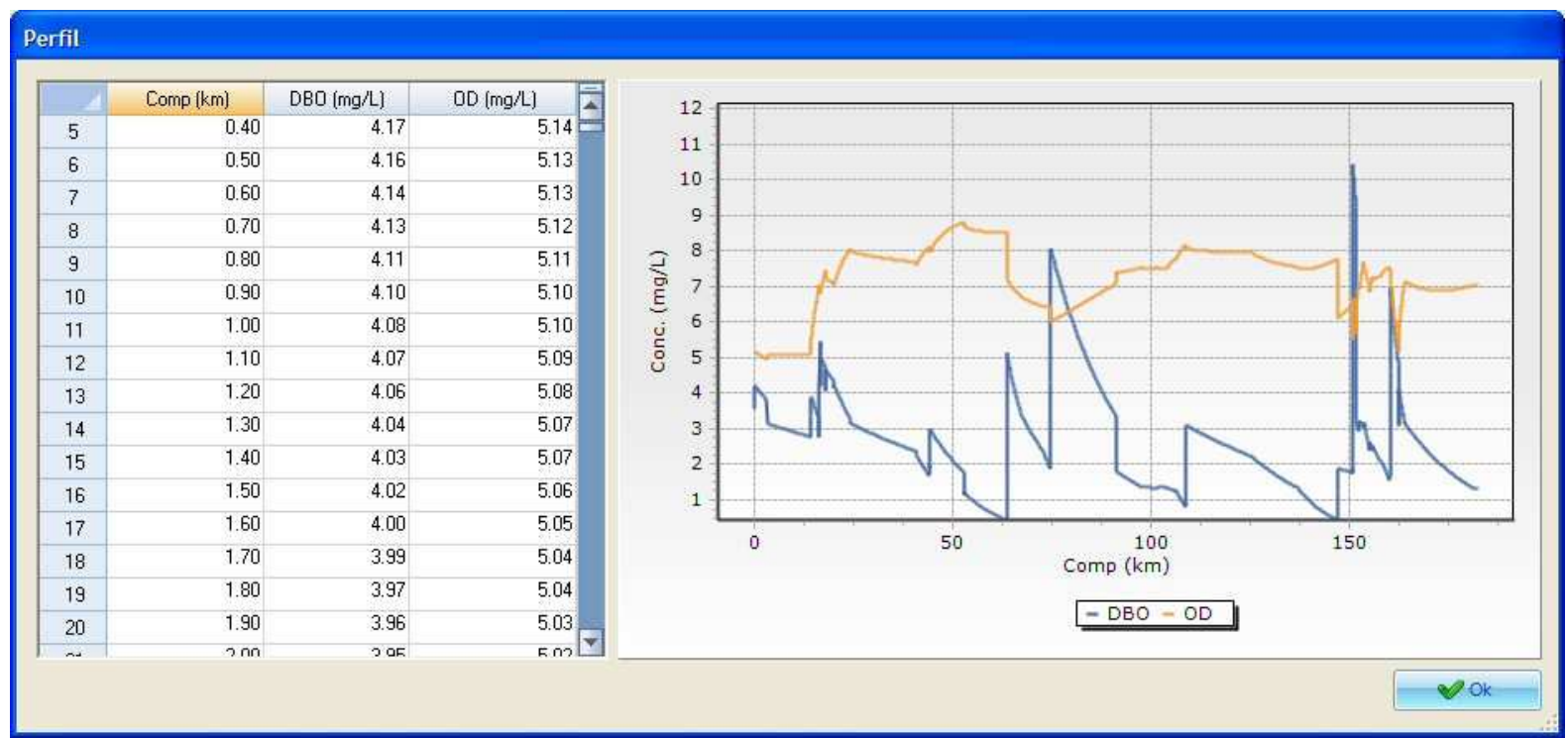

Figura 10.12 - Gráfico com perfil longitudinal para os parâmetros de qualidade d'água OD e DBO

A Figura 10.13 apresenta dos resultados obtidos para os trechos do curso 'd água 


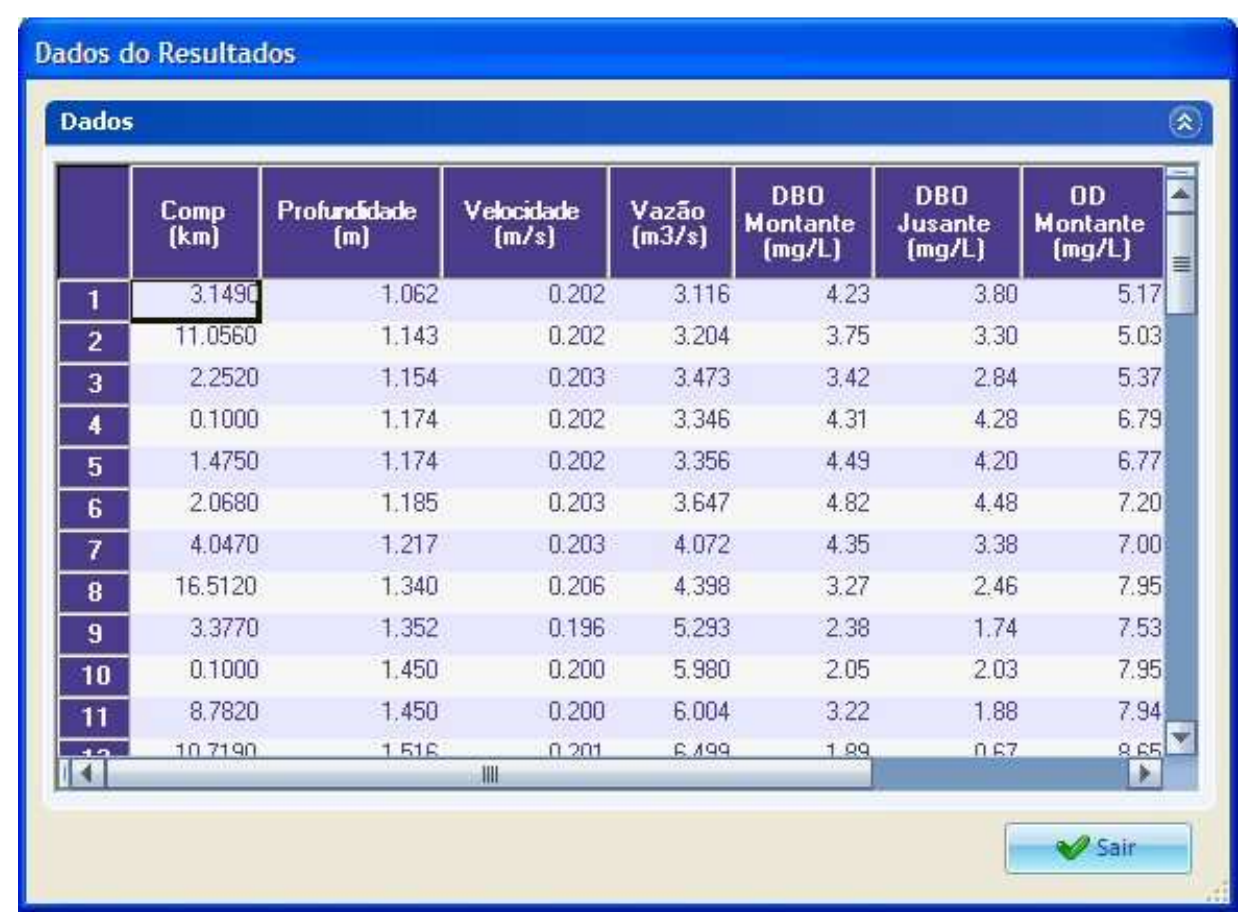

Figura 10.13 - Tela de apresentação dos resultados

A Figura 10.14 apresenta os resultados o obtidos para a função objetivo ao longo do número de gerações estipuladas para o algoritmo.

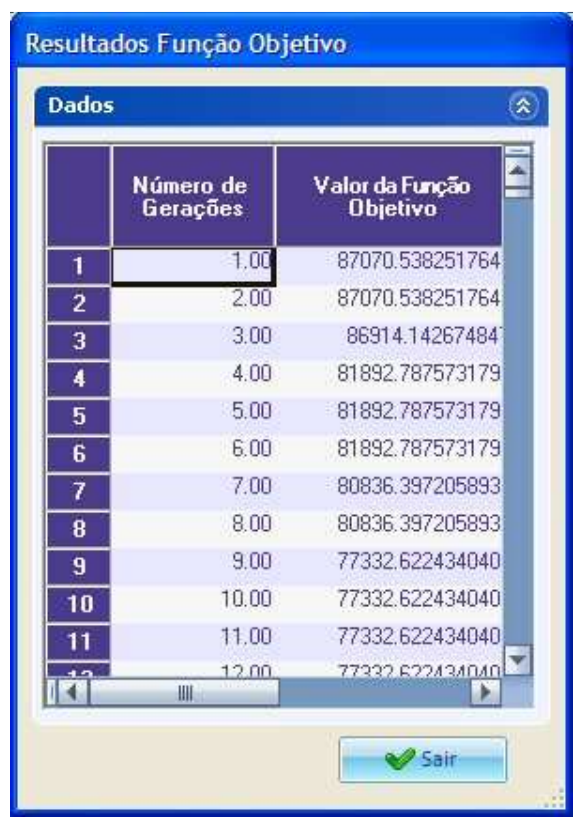

Figura 10.14 - Resultados da função objetivo para o número de gerações

A Figura 10.15 apresenta o gráfico com o valor obtido para a função objetivo ao longo das gerações do algoritmo. 


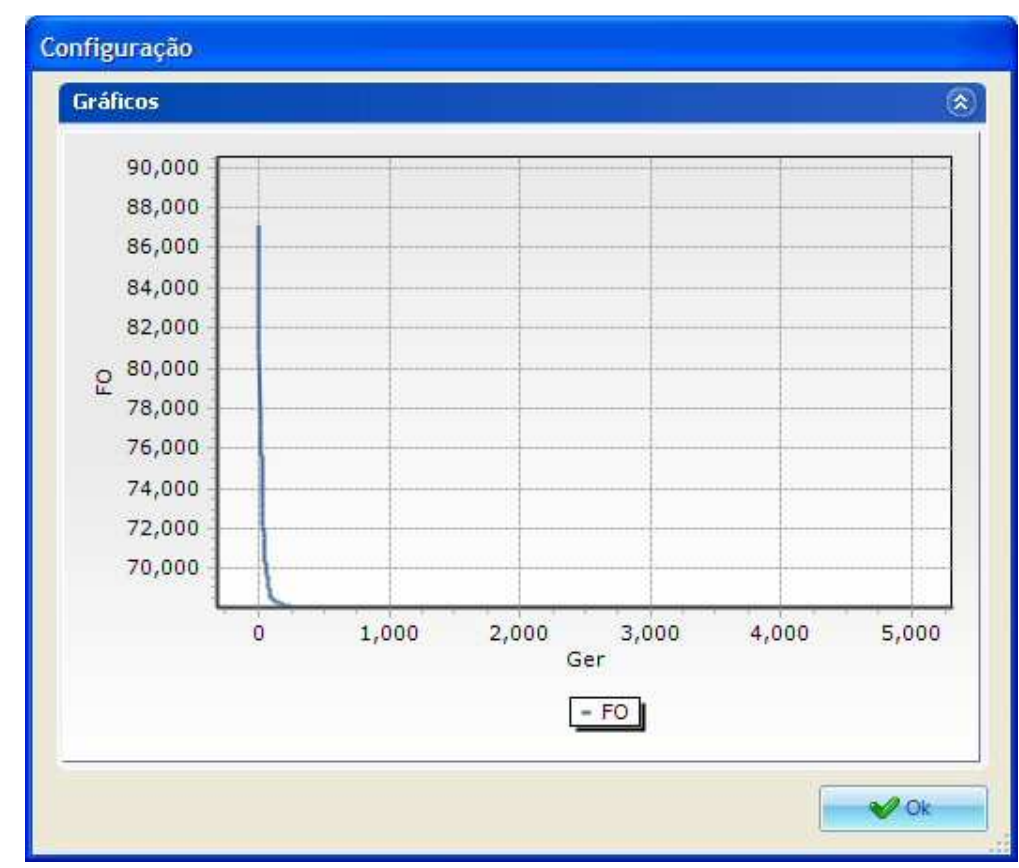

Figura 10.15 - Gráfico da função objetivo para as $\mathbf{n}$ gerações

O SSD ainda está em fase de desenvolvimento, onde os algoritmos e a interface estão sendo aperfeiçoados, sofrendo alterações na busca do melhor desempenho para os problemas propostos neste estudo.

$\mathrm{Na}$ fase atual da pesquisa os algoritmos estão sendo avaliados para sua aplicação no processo de outorga de diluição, onde se pretende otimizar as eficiências de tratamento de efluentes ao longo do corpo d'água, considerando os limites da classe de enquadramento dos corpo hídrico e o custo do tratamento. 


\subsection{ANEXO II -Dados das Estação de Monitoramento Quantitaivo e Qualitativo na Bacia do Atibaia}

\section{- Estações Fluviométricas}

Os dados fluviométricos utilizados para esta análise foram obtidos através do Banco de Dados Fluviométricos do Estado de São Paulo do Departamento de Águas e Energia Elétrica (DAEE), disponíveis no endereço eletrônico www.sigrh.sp.gov.br.

Os postos fluviométricos utilizados neste estudo apresentam-se na Tabela 10.1.

\begin{tabular}{cc} 
Tabela 10.1 - Estações fluviométricas utilizadas no estudo \\
\hline Sub-bacia & Posto \\
\hline \multirow{3}{*}{ Atibaia } & 3D-003 \\
& 3D-006 \\
& $4 \mathrm{D}-009$ \\
\hline
\end{tabular}

Estes postos serviram para determinação das características geométricas e velocidades para os trechos de rio analisados. Através da seção transversal e da equação cota descarga de cada posto foi possível estimar a largura da base e velocidade de cada seção de interesse ponderando o valor de cada trecho de rio com os valores dos postos de montante e jusante pela distância.

\section{- Estações de Qualidade da Água}

As informações sobre a qualidade da água nas sub-bacias do Rio Piracicaba foram adquiridas junto ao banco de dados do Sistema de Suporte a Decisão das Bacias dos rios Piracicaba, Capivari e Jundiaí - SSD-PCJ, sendo atualizadas com informações dos Relatórios de Qualidade das Águas Interiores do Estado de São Paulo da CETESB (2002 a 2009). Os postos de qualidade utilizados encontram-se na Tabela 10.2.

Tabela 10.2 - Estações de qualidade da água utilizadas no estudo

\begin{tabular}{|c|c|c|c|c|c|c|}
\hline Bacia & Posto & \multicolumn{2}{|c|}{ Coordenadas } & Descrição & Município & $\begin{array}{c}\text { Período de } \\
\text { dados }\end{array}$ \\
\hline \multirow{4}{*}{ Atibaia } & ATIB 02010 & $23^{0} 06^{\prime} 12^{\prime \prime}$ & $46^{0} 32^{\prime} 42^{\prime \prime}$ & $\begin{array}{l}\text { Junto à captação do } \\
\text { município de Atibaia. }\end{array}$ & Atibaia & $1995-2009$ \\
\hline & ATIB 02030 & $22^{0} 58^{\prime} 11^{\prime \prime}$ & $46^{0} 50^{\prime} 48^{\prime \prime}$ & $\begin{array}{l}\text { Na captação de Itatiba. } \\
\text { Rua Fioravante Piovani. }\end{array}$ & Itatiba & $2002-2009$ \\
\hline & ATIB 02035 & $22^{0} 56^{\prime} 16^{\prime \prime}$ & $46^{0} 56^{\prime} 01^{\prime \prime}$ & Na captação de Valinhos. & Valinhos & $2000-2009$ \\
\hline & ATIB 02065 & $22^{0} 54^{\prime} 18^{\prime \prime}$ & $46^{0} 58^{\prime} 26^{\prime \prime}$ & $\begin{array}{l}\text { Na captação de } \\
\text { Campinas, na divisa entre } \\
\text { os municípios de } \\
\text { Campinas e Valinhos. }\end{array}$ & Campinas & $1989-2009$ \\
\hline
\end{tabular}




\begin{tabular}{c|c|c|c|l|c|c}
\hline Bacia & Posto & \multicolumn{2}{|c|}{ Coordenadas } & \multicolumn{1}{c|}{ Descrição } & Município & $\begin{array}{c}\text { Período de } \\
\text { dados }\end{array}$ \\
\hline & ATIB 02300 & $22^{0} 45^{\prime} 07^{\prime \prime}$ & $47^{0} 06^{\prime} 20^{\prime \prime}$ & $\begin{array}{l}\text { No canal de captação da } \\
\text { Rhodia, em Paulínia. }\end{array}$ & Paulínia & $2000-2009$ \\
\cline { 2 - 7 } & ATIB 02605 & $22^{0} 44^{\prime} 43^{\prime \prime}$ & $47^{0} 09^{\prime} 35^{\prime \prime}$ & $\begin{array}{l}\text { Ponte da Rodovia SP - } \\
332 \text { que liga Campinas a } \\
\text { Cosmópolis. }\end{array}$ & Paulínia & $1989-2009$ \\
\cline { 2 - 7 } & ATIB 02800 & $22^{0} 45^{\prime} 41^{\prime \prime}$ & $47^{0} 10^{\prime} 24^{\prime \prime}$ & $\begin{array}{l}\text { Na captação de Sumaré, } \\
\text { perto do Mini-Pantanal de } \\
\text { Paulinia }\end{array}$ & Paulínia & $2002-2009$ \\
\cline { 2 - 7 } & ATIB 02900 & $22^{0} 41^{\prime} 54^{\prime \prime}$ & $47^{0} 17^{\prime} 27^{\prime \prime}$ & $\begin{array}{l}\text { Ponte de Salto Grande, a } \\
\text { jusante do Reservatório da } \\
\text { CPFL. }\end{array}$ & Americana & $2000-2006$ \\
\hline
\end{tabular}

As informações apresentadas nos postos de qualidade da CETESB permitem a verificação quanto à qualidade da calibração realizada no modelo de qualidade da água em cada sub-bacia simulada. Esta verificação foi realizada em função de uma análise estatística através das estruturas de box-plot, Tabela 10.3 e Tabela 10.4 .

Tabela 10.3 - Dados das estação de monitoramento de qualidade no Rio Atibaia

\begin{tabular}{c|c|c|c|c|c|c|c|c}
\hline \multirow{2}{*}{ Estação } & \multicolumn{2}{|c|}{ ATIB2010 } & \multicolumn{2}{c|}{ ATIB2035 } & \multicolumn{2}{c|}{ ATIB2030 } & \multicolumn{3}{c}{ ATIB2065 } \\
\hline Parâmetro & $\begin{array}{c}\text { DBO } \\
(\mathrm{mg} / \mathrm{L})\end{array}$ & $\begin{array}{c}\text { OD } \\
(\mathrm{mg} / \mathrm{L})\end{array}$ & $\begin{array}{c}\text { DBO } \\
(\mathrm{mg} / \mathrm{L})\end{array}$ & $\begin{array}{c}\text { OD } \\
(\mathrm{mg} / \mathrm{L})\end{array}$ & $\begin{array}{c}\text { DBO } \\
(\mathrm{mg} / \mathrm{L})\end{array}$ & $\begin{array}{c}\text { OD } \\
(\mathrm{mg} / \mathrm{L})\end{array}$ & $\begin{array}{c}\text { DBO } \\
(\mathrm{mg} / \mathrm{L})\end{array}$ & $\begin{array}{c}\text { OD } \\
(\mathrm{mg} / \mathrm{L})\end{array}$ \\
\hline $3^{\circ}$ QUARTIL & 2.0 & 5.7 & 3.0 & 7.6 & 3.0 & 6.7 & 4.0 & 7.3 \\
\hline MÁXIMO & 16.0 & 7.2 & 7.0 & 8.7 & 6.0 & 7.6 & 17.0 & 8.6 \\
\hline MíNIMO & 1.0 & 3.2 & 1.0 & 4.9 & 1.0 & 5.0 & 1.0 & 4.5 \\
\hline MEDIANA & 1.0 & 5.0 & 2.0 & 7.2 & 2.0 & 6.2 & 3.0 & 6.8 \\
\hline $1^{\circ}$ QUARTIL & 1.0 & 4.4 & 2.0 & 6.9 & 1.0 & 5.7 & 3.0 & 6.1 \\
\hline
\end{tabular}

Tabela 10.4 - Dados das estação de monitoramento de qualidade no Rio Atibaia

\begin{tabular}{c|c|c|c|c|c|c|c|c}
\hline Estação & \multicolumn{2}{|c|}{ ATIB2300 } & \multicolumn{2}{c|}{ ATIB2605 } & \multicolumn{2}{c}{ ATIB2900 } & \multicolumn{3}{c}{ ATIB2800 } \\
\hline Parâmetro & $\begin{array}{c}\text { DBO } \\
(\mathrm{mg} / \mathrm{L})\end{array}$ & $\begin{array}{c}\text { OD } \\
(\mathrm{mg} / \mathrm{L})\end{array}$ & $\begin{array}{c}\mathrm{DBO} \\
(\mathrm{mg} / \mathrm{L})\end{array}$ & $\begin{array}{c}\text { OD } \\
(\mathrm{mg} / \mathrm{L})\end{array}$ & $\begin{array}{c}\mathrm{DBO} \\
(\mathrm{mg} / \mathrm{L})\end{array}$ & $\begin{array}{c}\text { OD } \\
(\mathrm{mg} / \mathrm{L})\end{array}$ & $\begin{array}{c}\mathrm{DBO} \\
(\mathrm{mg} / \mathrm{L})\end{array}$ & $\begin{array}{c}\text { OD } \\
(\mathrm{mg} / \mathrm{L})\end{array}$ \\
\hline $3^{\circ}$ QUARTIL & 3.0 & 6.8 & 7.0 & 6.0 & 4.0 & 5.8 & 8.0 & 5.3 \\
\hline MÁXIMO & 12.0 & 7.9 & 51.0 & 7.1 & 11.0 & 8.7 & 14.0 & 7.6 \\
\hline MíNIMO & 1.0 & 3.4 & 1.0 & 1.6 & 1.0 & 0.9 & 2.0 & 0.6 \\
\hline MEDIANA & 2.0 & 6.3 & 5.0 & 5.4 & 3.0 & 4.4 & 6.0 & 4.6 \\
\hline $1^{\circ}$ QUARTIL & 2.0 & 5.7 & 4.0 & 5.1 & 2.0 & 3.5 & 5.0 & 3.9 \\
\hline
\end{tabular}




\subsection{ANEXO III - Dados de Entrada do modelo}

\section{- Determinação das vazões}

As vazões naturais das sub-bacias de interesse foram determinadas a partir do estudo de regionalização hidrológica do Estado de São Paulo, através do Sistema de Informações para o Gerenciamento de Recursos Hídricos do Estado de São Paulo (http://www.sigrh.sp.gov.br). A vazão de referência determinada para este estudo foi a $Q_{95 \%}$ que corresponde a vazão com $95 \%$ de permanência no curso d'água. Esta vazão foi escolhida por representar uma condição de escassez que possibilita o estudo dos impactos produzidos pelo uso.

\section{- Determinação da largura da base para os trechos}

Os postos fluviométricos existentes na bacia do Rio Atibaia, permitiram estimar a largura da base $(L)$ no trecho em que este posto se encontra. Esta estimativa foi realizada através da análise da linha d'água média de cada posto com a largura da seção representativa da mesma. A extrapolação para os links intermediários foi realizada através da interpolação entre as características dos postos a montante e a jusante do mesmo.

\section{- Determinação da velocidade nos trechos}

A velocidade de cada trecho, necessária para os equacionamentos de qualidade da água, foi determinada através obtenção da equação cota descarga dos postos fluviométricos.

A partir da equação cota descarga foi realizado o processo inverso, uma vez que a vazão de referência já havia sido obtida, então, determinou-se a cota $(\mathrm{H})$ para a respectiva vazão. Desta forma, foi determinada a área da seção $\left(H^{*} L\right)$ que juntamente com a vazão de referência estipulou-se a velocidade desejada. Este processo foi realizado para os trechos que apresentavam os postos fluviométricos e para os trechos intermediários foi realizada uma extrapolação considerando as informações de montante e jusante.

\section{- Sub-Bacia}

Para cada sub-bacia existe um trecho de rio no modelo, estas sub-bacia foram subdivididas buscando um nível de discretização adequado para a representação do estudo. Para determinação do nível de discretização foi considerada a rede hidrográfica e os usuários cadastrados, buscando uma homogeneidade espacial das sub-bacias. Os valores de uso, captações e lançamentos assim como a contribuição natural de cada sub-bacia é 
agrupado no final do trecho de rio correspondente a sub-bacia, onde é realizado o balanço. A Tabela 10.5 apresenta os coeficientes adotados para os trechos do Rio Atibaia

- Captações, Lançamentos por usuário e finalidade de uso e contribuição natural

A identificação dos usuários da bacia do Rio Atibaia foi obtida junto ao cadastro de usuários da Bacia do PCJ. A Tabela 10.6 apresenta as informações sobre os usuários e a contribuição natural de cada sub-bacia. 
Tabela 10.5 - Dados de entrada do modelo: comprimento do trecho, classe de enquadramento, limites para os coeficientes de qualidade da água e coeficientes de velocidade e profundidade para os trechos no Rio Atibaia

\begin{tabular}{|c|c|c|c|c|c|c|c|c|c|c|c|c|}
\hline \multirow{2}{*}{ Trecho } & \multirow{2}{*}{$\begin{array}{c}\text { Comprimento } \\
\text { (km) }\end{array}$} & \multirow{2}{*}{ Classe } & \multicolumn{2}{|c|}{$\mathrm{Ka}$} & \multicolumn{2}{|c|}{$\mathrm{Kd}$} & \multicolumn{2}{|c|}{ Ks } & \multirow{2}{*}{$\begin{array}{l}\text { Coeficiente } \\
\text { Velocidade }\end{array}$} & \multirow{2}{*}{$\begin{array}{c}\text { Coeficiente } \\
\text { Velocidade } \\
\text { Exp }\end{array}$} & \multirow{2}{*}{$\begin{array}{c}\text { Coeficiente } \\
\text { H }\end{array}$} & \multirow{2}{*}{$\begin{array}{c}\text { Coeficiente } \\
\text { H Prof }\end{array}$} \\
\hline & & & Min & Max & Min & Max & Min & Max & & & & \\
\hline 1 & 3.15 & 5 & 0.10 & 6.00 & 0.10 & 1.00 & 0.00 & 0.80 & 0.20 & 0.01 & 1.05 & 0.01 \\
\hline 2 & 11.06 & 5 & 0.10 & 6.00 & 0.10 & 1.00 & 0.00 & 0.80 & 0.20 & 0.01 & 1.13 & 0.01 \\
\hline 3 & 2.25 & 5 & 0.10 & 6.00 & 0.10 & 1.00 & 0.00 & 0.80 & 0.20 & 0.01 & 1.14 & 0.01 \\
\hline 4 & 0.10 & 5 & 0.10 & 6.00 & 0.10 & 1.00 & 0.00 & 0.80 & 0.20 & 0.01 & 1.16 & 0.01 \\
\hline 5 & 1.48 & 5 & 0.10 & 6.00 & 0.10 & 1.00 & 0.00 & 0.80 & 0.20 & 0.01 & 1.16 & 0.01 \\
\hline 6 & 2.07 & 5 & 0.10 & 6.00 & 0.10 & 1.00 & 0.00 & 0.80 & 0.20 & 0.01 & 1.17 & 0.01 \\
\hline 7 & 4.05 & 5 & 0.10 & 6.00 & 0.10 & 1.00 & 0.00 & 0.80 & 0.20 & 0.01 & 1.2 & 0.01 \\
\hline 8 & 16.51 & 5 & 0.10 & 6.00 & 0.10 & 1.00 & 0.00 & 0.80 & 0.20 & 0.02 & 1.32 & 0.01 \\
\hline 9 & 3.38 & 5 & 0.10 & 6.00 & 0.10 & 1.00 & 0.00 & 0.80 & 0.19 & 0.02 & 1.33 & 0.01 \\
\hline 10 & 0.10 & 5 & 0.10 & 6.00 & 0.10 & 1.00 & 0.00 & 0.80 & 0.19 & 0.03 & 1.35 & 0.04 \\
\hline 11 & 8.78 & 5 & 0.10 & 6.00 & 0.10 & 1.00 & 0.00 & 1.60 & 0.19 & 0.03 & 1.35 & 0.04 \\
\hline 12 & 10.72 & 5 & 0.10 & 6.00 & 0.10 & 1.00 & 0.00 & 1.60 & 0.19 & 0.03 & 1.46 & 0.02 \\
\hline 13 & 3.69 & 5 & 0.10 & 6.00 & 0.10 & 1.00 & 0.00 & 1.60 & 0.19 & 0.03 & 1.48 & 0.02 \\
\hline 14 & 5.59 & 5 & 0.10 & 6.00 & 0.10 & 1.00 & 0.00 & 1.60 & 0.19 & 0.03 & 1.52 & 0.02 \\
\hline 15 & 1.78 & 5 & 0.10 & 6.00 & 0.10 & 1.00 & 0.00 & 1.60 & 0.19 & 0.03 & 1.49 & 0.03 \\
\hline 16 & 16.68 & 5 & 0.10 & 6.00 & 0.10 & 1.00 & 0.00 & 1.60 & 0.15 & 0.06 & 1.13 & 0.03 \\
\hline 17 & 6.45 & 5 & 0.10 & 6.00 & 0.10 & 1.00 & 0.00 & 1.60 & 0.14 & 0.06 & 1.04 & 0.01 \\
\hline 18 & 3.79 & 5 & 0.10 & 6.00 & 0.10 & 1.00 & 0.00 & 1.60 & 0.13 & 0.06 & 0.97 & 0.01 \\
\hline 19 & 2.16 & 5 & 0.10 & 6.00 & 0.10 & 1.00 & 0.00 & 1.60 & 0.13 & 0.06 & 0.93 & 0.01 \\
\hline 20 & 2.64 & 5 & 0.10 & 6.00 & 0.10 & 1.00 & 0.00 & 1.60 & 0.12 & 0.06 & 0.87 & 0.01 \\
\hline 21 & 2.30 & 5 & 0.10 & 6.00 & 0.10 & 1.00 & 0.00 & 1.60 & 0.12 & 0.06 & 0.83 & 0.01 \\
\hline 22 & 0.10 & 5 & 0.10 & 6.00 & 0.10 & 1.00 & 0.00 & 1.60 & 0.09 & 0.06 & 0.49 & 0.01 \\
\hline 23 & 0.10 & 5 & 0.10 & 6.00 & 0.10 & 1.00 & 0.00 & 1.60 & 0.09 & 0.06 & 0.49 & 0.01 \\
\hline 24 & 0.10 & 5 & 0.10 & 6.00 & 0.10 & 1.00 & 0.00 & 0.00 & 0.09 & 0.06 & 0.49 & 0.01 \\
\hline 25 & 16.74 & 5 & 0.10 & 6.00 & 0.10 & 1.00 & 0.00 & 0.00 & 0.09 & 0.06 & 0.49 & 0.01 \\
\hline
\end{tabular}




\begin{tabular}{|c|c|c|c|c|c|c|c|c|c|c|c|c|}
\hline \multirow{2}{*}{ Trecho } & \multirow{2}{*}{$\begin{array}{c}\text { Comprimento } \\
\text { (km) }\end{array}$} & \multirow{2}{*}{ Classe } & \multicolumn{2}{|c|}{$\mathrm{Ka}$} & \multicolumn{2}{|c|}{$\mathrm{Kd}$} & \multicolumn{2}{|c|}{ Ks } & \multirow{2}{*}{$\begin{array}{l}\text { Coeficiente } \\
\text { Velocidade }\end{array}$} & \multirow{2}{*}{$\begin{array}{c}\text { Coeficiente } \\
\text { Velocidade } \\
\text { Exp }\end{array}$} & \multirow{2}{*}{$\begin{array}{c}\text { Coeficiente } \\
\text { H }\end{array}$} & \multirow{2}{*}{$\begin{array}{c}\text { Coeficiente } \\
\text { H Prof }\end{array}$} \\
\hline & & & Min & Max & Min & Max & Min & Max & & & & \\
\hline 26 & 11.12 & 5 & 0.10 & 6.00 & 0.10 & 1.00 & 0.00 & 0.00 & 0.09 & 0.06 & 1.48 & 0.01 \\
\hline 27 & 10.45 & 5 & 0.10 & 6.00 & 0.10 & 1.00 & 0.00 & 0.00 & 0.09 & 0.06 & 2.41 & 0.01 \\
\hline 28 & 0.10 & 5 & 0.10 & 6.00 & 0.10 & 1.00 & 0.00 & 0.00 & 0.09 & 0.06 & 2.71 & 0.01 \\
\hline 29 & 3.24 & 5 & 0.10 & 6.00 & 0.10 & 1.00 & 0.00 & 0.00 & 0.09 & 0.06 & 2.71 & 0.01 \\
\hline 30 & 0.10 & 5 & 0.10 & 6.00 & 0.10 & 1.60 & 0.00 & 0.00 & 0.09 & 0.06 & 2.75 & 0.02 \\
\hline 31 & 0.10 & 5 & 0.10 & 6.00 & 0.10 & 1.60 & 0.00 & 0.00 & 0.09 & 0.06 & 2.75 & 0.02 \\
\hline 32 & 1.10 & 5 & 0.10 & 6.00 & 0.10 & 1.60 & 0.00 & 0.00 & 0.09 & 0.06 & 2.75 & 0.02 \\
\hline 33 & 0.10 & 5 & 0.10 & 6.00 & 0.10 & 1.60 & 0.00 & 0.00 & 0.09 & 0.06 & 2.88 & 0.02 \\
\hline 34 & 0.10 & 5 & 0.10 & 6.00 & 0.10 & 1.60 & 0.00 & 0.00 & 0.09 & 0.06 & 2.88 & 0.02 \\
\hline 35 & 0.10 & 5 & 0.10 & 6.00 & 0.10 & 1.60 & 0.00 & 0.00 & 0.09 & 0.06 & 2.88 & 0.02 \\
\hline 36 & 0.10 & 5 & 0.10 & 6.00 & 0.10 & 1.60 & 0.00 & 0.00 & 0.09 & 0.06 & 2.88 & 0.02 \\
\hline 37 & 0.10 & 5 & 0.10 & 6.00 & 0.10 & 1.60 & 0.00 & 0.00 & 0.09 & 0.06 & 2.88 & 0.02 \\
\hline 38 & 0.10 & 5 & 0.10 & 6.00 & 0.10 & 1.60 & 0.00 & 0.00 & 0.09 & 0.06 & 2.88 & 0.02 \\
\hline 39 & 0.10 & 5 & 0.10 & 6.00 & 0.10 & 1.60 & 0.00 & 0.00 & 0.09 & 0.06 & 2.88 & 0.02 \\
\hline 40 & 0.94 & 5 & 0.10 & 6.00 & 0.10 & 1.60 & 0.00 & 0.00 & 0.09 & 0.06 & 2.88 & 0.02 \\
\hline 41 & 0.10 & 5 & 0.10 & 6.00 & 0.10 & 1.60 & 0.00 & 0.00 & 0.10 & 0.02 & 2.99 & 0.03 \\
\hline 42 & 1.59 & 5 & 0.10 & 6.00 & 0.10 & 1.60 & 0.00 & 0.00 & 0.10 & 0.02 & 2.99 & 0.03 \\
\hline 43 & 0.52 & 5 & 0.10 & 6.00 & 0.10 & 1.60 & 0.00 & 0.00 & 0.10 & 0.01 & 3.05 & 0.03 \\
\hline 44 & 0.10 & 5 & 0.10 & 6.00 & 0.10 & 1.60 & 0.00 & 0.00 & 0.10 & 0.01 & 3.23 & 0.03 \\
\hline 45 & 0.10 & 5 & 0.10 & 6.00 & 0.10 & 1.60 & 0.00 & 0.00 & 0.10 & 0.01 & 3.23 & 0.03 \\
\hline 46 & 0.10 & 5 & 0.10 & 6.00 & 0.10 & 1.60 & 0.00 & 0.00 & 0.10 & 0.01 & 3.23 & 0.03 \\
\hline 47 & 1.75 & 5 & 0.10 & 6.00 & 0.10 & 1.60 & 0.00 & 0.00 & 0.10 & 0.01 & 3.23 & 0.03 \\
\hline 48 & 0.90 & 5 & 0.10 & 6.00 & 0.10 & 1.60 & 0.00 & 0.00 & 0.10 & 0.02 & 3.31 & 0.02 \\
\hline 49 & 1.52 & 5 & 0.10 & 6.00 & 0.10 & 1.60 & 0.00 & 0.00 & 0.10 & 0.02 & 3.44 & 0.02 \\
\hline 50 & 0.10 & 5 & 0.10 & 6.00 & 0.10 & 1.60 & 0.00 & 0.00 & 0.10 & 0.02 & 3.68 & 0.02 \\
\hline 51 & 2.28 & 5 & 0.10 & 6.00 & 0.10 & 1.60 & 0.00 & 0.00 & 0.10 & 0.02 & 3.68 & 0.02 \\
\hline
\end{tabular}




\begin{tabular}{|c|c|c|c|c|c|c|c|c|c|c|c|c|}
\hline \multirow{2}{*}{ Trecho } & \multirow{2}{*}{$\begin{array}{l}\text { Comprimento } \\
(\mathbf{k m})\end{array}$} & \multirow{2}{*}{ Classe } & \multicolumn{2}{|c|}{$\mathrm{Ka}$} & \multicolumn{2}{|c|}{$\mathrm{Kd}$} & \multicolumn{2}{|c|}{$\mathrm{Ks}$} & \multirow{2}{*}{$\begin{array}{l}\text { Coeficiente } \\
\text { Velocidade }\end{array}$} & \multirow{2}{*}{$\begin{array}{l}\text { Coeficiente } \\
\text { Velocidade } \\
\text { Exp }\end{array}$} & \multirow{2}{*}{$\begin{array}{c}\text { Coeficiente } \\
\text { H }\end{array}$} & \multirow{2}{*}{$\begin{array}{c}\text { Coeficiente } \\
\text { H Prof }\end{array}$} \\
\hline & & & Min & Max & Min & Max & Min & Max & & & & \\
\hline 52 & 0.10 & 5 & 0.10 & 6.00 & 0.10 & 1.60 & 0.00 & 0.00 & 0.10 & 0.02 & 3.79 & 0.02 \\
\hline 53 & 1.39 & 5 & 0.10 & 6.00 & 0.10 & 1.60 & 0.00 & 0.00 & 0.10 & 0.02 & 3.79 & 0.02 \\
\hline 54 & 17.53 & 5 & 0.10 & 6.00 & 0.10 & 1.60 & 0.00 & 0.00 & 0.10 & 0.02 & 3.79 & 0.02 \\
\hline
\end{tabular}


Tabela 10.6- Dados de entrada do modelo - Captações, Lançamentos e finalidade de uso para os usuários d'água no Rio Atibaia e contribuição natural

\begin{tabular}{|c|c|c|c|c|c|c|c|c|c|c|c|c|}
\hline \multirow[b]{2}{*}{ Trecho } & \multirow{2}{*}{$\begin{array}{c}\text { Comprimento } \\
\text { (km) }\end{array}$} & \multirow[b]{2}{*}{ Usuários } & \multirow{2}{*}{$\begin{array}{c}\text { Finalidade } \\
\text { de Uso }\end{array}$} & \multirow{2}{*}{$\begin{array}{l}\text { Qcap. } \\
\left(\mathrm{m}^{3} / \mathrm{s}\right)\end{array}$} & \multicolumn{4}{|c|}{ Efluentes (Lançamentos) } & \multicolumn{4}{|c|}{ Contribuição Natural } \\
\hline & & & & & $\begin{array}{c}Q \\
\left(\mathrm{~m}^{3} / \mathrm{s}\right)\end{array}$ & $\begin{array}{c}\text { DBO } \\
\text { (mg/L) }\end{array}$ & $\begin{array}{c}\text { OD } \\
(\mathrm{mg} / \mathrm{L})\end{array}$ & $\begin{array}{c}\text { Temp } \\
\text { (.C) }\end{array}$ & $\begin{array}{c}\mathbf{Q} \\
\left(\mathrm{m}^{3} / \mathrm{s}\right)\end{array}$ & $\begin{array}{c}\text { DBO } \\
(\mathrm{mg} / \mathrm{L})\end{array}$ & $\begin{array}{c}\text { OD } \\
(\mathrm{mg} / \mathrm{L})\end{array}$ & $\begin{array}{c}\text { Temp } \\
\text { (.C) }\end{array}$ \\
\hline Trecho 1 & 3.15 & Usuário 01 & Doméstico & 0.0188 & 0.0160 & 300.0 & 0.0 & 20 & 0.0880 & 2.0 & 8.0 & 20 \\
\hline Trecho 2 & 11.06 & Usuário 02 & Indústria & 0.0001 & - & - & 0.0 & 20 & 0.5390 & 2.0 & 8.0 & 20 \\
\hline Trecho 3 & 2.25 & Usuário 03 & Doméstico & 0.2864 & 0.0158 & 300.0 & 0.0 & 20 & 0.0440 & 2.0 & 8.0 & 20 \\
\hline Trecho 4 & 0.10 & Usuário 04 & Doméstico & 0.2864 & 0.1163 & 89.5 & 0.0 & 20 & 0.0000 & 2.0 & 7.0 & 20 \\
\hline Trecho 5 & 1.48 & Usuário 05 & Indústria & - & 0.0103 & 300.0 & 0.0 & 20 & 0.1990 & 2.0 & 7.0 & 20 \\
\hline Trecho 6 & 2.07 & Usuário 06 & Indústria & - & 0.0922 & 33.4 & 0.0 & 20 & 0.4250 & 2.0 & 7.0 & 20 \\
\hline Trecho 7 & 4.05 & Usuário 07 & Indústria & 0.0014 & 0.0008 & 498.3 & 0.0 & 20 & 0.3260 & 2.0 & 7.0 & 20 \\
\hline Trecho 8 & 16.51 & Usuário 08 & Agrícola & 0.0007 & - & - & 0.0 & 20 & 0.8950 & 2.0 & 7.0 & 20 \\
\hline Trecho 9 & 3.38 & Usuário 09 & Agrícola & 0.0004 & - & - & 0.0 & 20 & 0.6900 & 2.0 & 7.0 & 20 \\
\hline Trecho 10 & 0.10 & Usuário 10 & Indústria & 0.0190 & 0.0160 & 106.0 & 0.0 & 20 & 0.0000 & 2.0 & 7.0 & 20 \\
\hline Trecho 11 & 8.78 & Usuário 11 & Doméstico & - & 0.0240 & 300.0 & 0.0 & 20 & 0.5220 & 2.0 & 7.0 & 20 \\
\hline Trecho 12 & 10.72 & Usuário 12 & Indústria & 0.0268 & - & - & 0.0 & 20 & 0.6930 & 2.0 & 7.0 & 20 \\
\hline Trecho 13 & 3.69 & Usuário 13 & Doméstico & 1.2000 & 1.2000 & 33.0 & 0.0 & 20 & 0.0510 & 2.0 & 7.0 & 20 \\
\hline Trecho 14 & 5.59 & Usuário 14 & Indústria & 0.0008 & 0.0034 & 12.5 & 0.0 & 20 & 0.1980 & 2.0 & 7.0 & 20 \\
\hline Trecho 15 & 1.78 & Usuário 15 & Doméstico & 0.3100 & - & - & 0.0 & 20 & 0.0270 & 2.0 & 7.0 & 20 \\
\hline Trecho 16/Afluente 1 & 16.68 & Usuário 16 & Doméstico & - & 0.5800 & 90.6 & 0.0 & 20 & 0.9250 & 2.0 & 7.0 & 20 \\
\hline Trecho 17 & 6.45 & Usuário 17 & Energia & 0.1700 & - & - & 0.0 & 20 & 0.1440 & 2.0 & 7.0 & 20 \\
\hline Trecho 18 & 3.79 & Usuário 18 & Doméstico & 0.1700 & - & - & 0.0 & 20 & 0.6050 & 2.0 & 7.0 & 20 \\
\hline Trecho 19 & 2.16 & Usuário 19 & Agrícola & 0.0028 & - & - & 0.0 & 20 & 0.0230 & 2.0 & 7.0 & 20 \\
\hline Trecho 20 & 2.64 & Usuário 20 & Doméstico & 3.2167 & - & - & 0.0 & 20 & 0.0470 & 2.0 & 7.0 & 20 \\
\hline Trecho 21 & 2.30 & Usuário 21 & Indústria & - & 0.0050 & 6.0 & 0.0 & 20 & 0.3080 & 2.0 & 7.0 & 20 \\
\hline Trecho 22 & 0.10 & Usuário 22 & Indústria & 0.0097 & 0.0042 & 6.0 & 0.0 & 20 & 0.0000 & 2.0 & 7.0 & 20 \\
\hline Trecho 23 & 0.10 & Usuário 23 & Indústria & 0.0167 & 0.0000 & - & 0.0 & 20 & 0.0000 & 2.0 & 7.0 & 20 \\
\hline Trecho 24 & 0.10 & Usuário 24 & Indústria & 0.0139 & 0.0139 & 2.0 & 0.0 & 20 & 0.0000 & 2.0 & 7.0 & 20 \\
\hline
\end{tabular}




\begin{tabular}{|c|c|c|c|c|c|c|c|c|c|c|c|c|}
\hline \multirow[b]{2}{*}{ Trecho } & \multirow{2}{*}{$\begin{array}{c}\text { Comprimento } \\
\text { (km) }\end{array}$} & \multirow[b]{2}{*}{ Usuários } & \multirow{2}{*}{$\begin{array}{l}\text { Finalidade } \\
\text { de Uso }\end{array}$} & \multirow{2}{*}{$\begin{array}{l}\text { Qcap. } \\
\left(\mathrm{m}^{3} / \mathrm{s}\right)\end{array}$} & \multicolumn{4}{|c|}{ Efluentes (Lançamentos) } & \multicolumn{4}{|c|}{ Contribuição Natural } \\
\hline & & & & & $\begin{array}{c}\mathbf{Q} \\
\left(\mathrm{m}^{3} / \mathrm{s}\right)\end{array}$ & $\begin{array}{c}\text { DBO } \\
\text { (mg/L) }\end{array}$ & $\begin{array}{c}\text { OD } \\
(\mathrm{mg} / \mathrm{L})\end{array}$ & $\begin{array}{c}\text { Temp } \\
(. C)\end{array}$ & $\begin{array}{c}Q \\
\left(m^{3} / s\right)\end{array}$ & $\begin{array}{c}\text { DBO } \\
(\mathrm{mg} / \mathrm{L})\end{array}$ & $\begin{array}{c}\text { OD } \\
(\mathrm{mg} / \mathrm{L})\end{array}$ & $\begin{array}{l}\text { Temp } \\
\text { (.C) }\end{array}$ \\
\hline Trecho 25 & 16.74 & Usuário 25 & Doméstico & - & 0.0636 & 250.0 & 0.0 & 20 & 0.4360 & 2.0 & 7.0 & 20 \\
\hline Trecho 26 & 11.12 & Usuário 26 & Indústria & 0.0001 & 0.0001 & - & 0.0 & 20 & 0.3690 & 2.0 & 7.0 & 20 \\
\hline Trecho 27 & 10.45 & Usuário 27 & Indústria & 0.0028 & 0.0028 & - & 0.0 & 20 & 0.0540 & 2.0 & 7.0 & 20 \\
\hline Trecho 28 & 0.10 & Usuário 28 & Indústria & 2.3472 & 2.0809 & 4.2 & 0.0 & 20 & 0.0000 & 2.0 & 7.0 & 20 \\
\hline Trecho 29 & 3.24 & Usuário 29 & Indústria & 0.0000 & 0.0389 & 141.0 & 0.0 & 20 & 0.0300 & 2.0 & 7.0 & 20 \\
\hline Trecho 30 & 0.10 & Usuário 30 & Agrícola & 2.3472 & 0.0000 & - & 0.0 & 20 & 0.0000 & 2.0 & 7.0 & 20 \\
\hline Trecho 31 & 0.10 & Usuário 31 & Indústria & 0.2083 & 0.0389 & 21.0 & 0.0 & 20 & 0.0000 & 2.0 & 7.0 & 20 \\
\hline Trecho 32 /Afluente 2 & 1.10 & Usuário 32 & Doméstico & 0.1250 & 1.3400 & 52.0 & 0.0 & 20 & 0.6530 & 2.0 & 7.0 & 20 \\
\hline Trecho 33 & 0.10 & Usuário 33 & Indústria & 0.0051 & 0.0003 & 12.0 & 0.0 & 20 & 0.0000 & 2.0 & 7.0 & 20 \\
\hline Trecho 34 & 0.10 & Usuário 34 & Indústria & 0.0457 & - & - & 0.0 & 20 & 0.0000 & 2.0 & 7.0 & 20 \\
\hline Trecho 35 & 0.10 & Usuário 35 & Doméstico & 0.0556 & - & - & 0.0 & 20 & 0.0000 & 2.0 & 7.0 & 20 \\
\hline Trecho 36 & 0.10 & Usuário 36 & Agrícola & 0.0061 & - & - & 0.0 & 20 & 0.0000 & 2.0 & 7.0 & 20 \\
\hline Trecho 37 & 0.10 & Usuário 37 & Doméstico & 0.5611 & - & - & 0.0 & 20 & 0.0000 & 2.0 & 7.0 & 20 \\
\hline Trecho 38 & 0.10 & Usuário 38 & Agrícola & 0.0861 & - & - & 0.0 & 20 & 0.0000 & 2.0 & 7.0 & 20 \\
\hline Trecho 39 & 0.10 & Usuário 39 & Indústria & 0.9361 & 0.0833 & 29.0 & 0.0 & 20 & 0.0000 & 2.0 & 7.0 & 20 \\
\hline Trecho 40 & 0.94 & Usuário 40 & Agrícola & 0.0067 & - & - & 0.0 & 20 & 0.0080 & 2.0 & 7.0 & 20 \\
\hline Trecho 41 & 0.10 & Usuário 41 & Indústria & 0.0013 & 0.0004 & 12.0 & 0.0 & 20 & 0.0000 & 2.0 & 7.0 & 20 \\
\hline Trecho 42 & 1.59 & Usuário 42 & Indústria & 0.0278 & 0.0178 & 87.0 & 0.0 & 20 & 0.0100 & 2.0 & 7.0 & 20 \\
\hline Trecho 43 & 0.52 & Usuário 43 & Indústria & - & 0.1890 & 11.7 & 0.0 & 20 & 0.0160 & 2.0 & 7.0 & 20 \\
\hline Trecho 44 & 0.10 & Usuário 44 & Indústria & 0.0278 & 0.0001 & 12.0 & 0.0 & 20 & 0.0000 & 2.0 & 7.0 & 20 \\
\hline Trecho 45 & 0.10 & Usuário 45 & Indústria & 0.0738 & 0.0594 & 18.9 & 0.0 & 20 & 0.0000 & 2.0 & 7.0 & 20 \\
\hline Trecho 46 & 0.10 & Usuário 46 & Indústria & 0.0739 & 0.0011 & 20.0 & 0.0 & 20 & 0.0000 & 2.0 & 7.0 & 20 \\
\hline Trecho 47 & 1.75 & Usuário 47 & Agrícola & 0.0006 & - & - & 0.0 & 20 & 0.0060 & 2.0 & 7.0 & 20 \\
\hline Trecho 48 & 0.90 & Usuário 48 & Indústria & - & 0.0014 & 24.4 & 0.0 & 20 & 0.0000 & 2.0 & 7.0 & 20 \\
\hline Trecho 49 & 1.52 & Usuário 49 & Indústria & 0.0010 & - & - & 0.0 & 20 & 0.0610 & 2.0 & 7.0 & 20 \\
\hline
\end{tabular}




\begin{tabular}{|c|c|c|c|c|c|c|c|c|c|c|c|c|}
\hline \multirow[b]{2}{*}{ Trecho } & \multirow{2}{*}{$\begin{array}{c}\text { Comprimento } \\
(\mathbf{k m})\end{array}$} & \multirow[b]{2}{*}{ Usuários } & \multirow{2}{*}{$\begin{array}{c}\text { Finalidade } \\
\text { de Uso }\end{array}$} & \multirow{2}{*}{$\begin{array}{l}\text { Qcap. } \\
\left(m^{3} / s\right)\end{array}$} & \multicolumn{4}{|c|}{ Efluentes (Lançamentos) } & \multicolumn{4}{|c|}{ Contribuição Natural } \\
\hline & & & & & $\begin{array}{c}\mathbf{Q} \\
\left(\mathrm{m}^{3} / \mathrm{s}\right)\end{array}$ & $\begin{array}{c}\text { DBO } \\
\text { (mg/L) }\end{array}$ & $\underset{(\mathrm{mg} / \mathrm{L})}{\mathrm{OD}}$ & $\begin{array}{c}\text { Temp } \\
\text { (.C) }\end{array}$ & $\begin{array}{c}\mathbf{Q} \\
\left(\mathrm{m}^{3} / \mathrm{s}\right)\end{array}$ & $\begin{array}{c}\text { DBO } \\
\text { (mg/L) }\end{array}$ & $\begin{array}{c}\mathrm{OD} \\
(\mathrm{mg} / \mathrm{L})\end{array}$ & $\begin{array}{c}\text { Temp } \\
\text { (.C) }\end{array}$ \\
\hline Trecho 50 & 0.10 & Usuário 50 & Indústria & 0.0694 & 0.0556 & 12.0 & 0.0 & 20 & 0.0000 & 2.0 & 7.0 & 20 \\
\hline Trecho 51 & 2.28 & Usuário 51 & Doméstico & - & 0.1350 & 300.0 & 0.0 & 20 & 0.0260 & 2.0 & 7.0 & 20 \\
\hline Trecho 52 & 0.10 & Usuário 52 & Doméstico & 0.4500 & 0.1425 & 57.2 & 0.0 & 20 & 0.0000 & 2.0 & 7.0 & 20 \\
\hline Trecho 53 & 1.39 & Usuário 53 & Agrícola & 0.5000 & - & - & 0.0 & 20 & 0.0000 & 2.0 & 7.0 & 20 \\
\hline Trecho 54 & 17.53 & Usuário 54 & Doméstico & 0.0872 & - & - & 0.0 & 20 & 0.2600 & 2.0 & 7.0 & 20 \\
\hline
\end{tabular}

